\title{
Economic crisis and institutional change : the crisis of Fordism from the perspective of the automobile industry
}

Citation for published version (APA):

Dankbaar, B. (1993). Economic crisis and institutional change : the crisis of Fordism from the perspective of the automobile industry. [Doctoral Thesis, Maastricht University]. Datawyse / Universitaire Pers Maastricht. https://doi.org/10.26481/dis.19930219bd

Document status and date:

Published: 01/01/1993

DOI:

10.26481/dis.19930219bd

Document Version:

Publisher's PDF, also known as Version of record

\section{Please check the document version of this publication:}

- A submitted manuscript is the version of the article upon submission and before peer-review. There can be important differences between the submitted version and the official published version of record.

People interested in the research are advised to contact the author for the final version of the publication, or visit the DOI to the publisher's website.

- The final author version and the galley proof are versions of the publication after peer review.

- The final published version features the final layout of the paper including the volume, issue and page numbers.

Link to publication

\footnotetext{
General rights rights.

- You may freely distribute the URL identifying the publication in the public portal. please follow below link for the End User Agreement:

www.umlib.nl/taverne-license

Take down policy

If you believe that this document breaches copyright please contact us at:

repository@maastrichtuniversity.nl

providing details and we will investigate your claim.
}

Copyright and moral rights for the publications made accessible in the public portal are retained by the authors and/or other copyright owners and it is a condition of accessing publications that users recognise and abide by the legal requirements associated with these

- Users may download and print one copy of any publication from the public portal for the purpose of private study or research.

- You may not further distribute the material or use it for any profit-making activity or commercial gain

If the publication is distributed under the terms of Article $25 \mathrm{fa}$ of the Dutch Copyright Act, indicated by the "Taverne" license above, 


\title{
ECONOMIC CRISIS \\ AND \\ INSTITUTIONAL CHANGE
}

\author{
The crisis of Fordism \\ from the perspective of the automobile industry
}

\section{PROEFSCHRIFT}

ter verkrijging van de graad van doctor aan de

Rijksuniversiteit Limburg te Maastricht, op gezag van de Rector Magnificus, Prof. mr. M.J. Cohen, volgens het besluit van het College van Dekanen, in het openbaar te verdedigen op vrijdag, 19 februari 1993 om 16.00 uur

door

BERNARD DANKBAAR

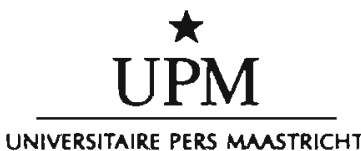


Promotor:

Beoordelingscommissie:
Prof. Dr. F. Prakke

Prof. Dr. L.L.G. Soete (voorzitter)

Prof. D. Jones (Universiteit van Wales, Cardiff)

Prof. Dr. R. Boyer (CEPREMAP, Parijs)

Prof. Dr. A.M. Sorge

Prof. Dr. Ch. Freeman

CIP-GEGEVENS KONINKLIJKE BIBLIOTHEEK, DEN HAAG

Dankbaar, Bernard

Economic crisis and institutional change : the crisis of

Fordism from the perspective of the automobile industry /

Bernard Dankbaar. - Maastricht : Universitaire Pers

Maastricht. - III.

Proefschrift Maastricht.- Met lit. opg.

ISBN 90-5278-055-2

NUGI 681

Trefw.: autoindustrie ; economische geschiedenis. 


\section{Contents}

\section{Preface}

1. Introduction and overview

1.1 The analysis of change in capitalist economies 1

1.2 Fordism

1.3 Crisis

1.4 System and coherence

PART I: Economic crisis and institutional change

2. Economics and institutions 9

2.1 Economics and capitalism 9

2.2 Countercurrents 13

2.3 Institutional economics 18

2.4 The régulation approach 23

$\begin{array}{lll}2.5 & \text { The logic of institutional change . } & 31\end{array}$

3. The crisis of Fordism

$\begin{array}{lll}3.1 & \text { Fordism } & 39\end{array}$

3.2 The crisis of Fordism 48

3.3 Others about the crisis of Fordism 55

3.4 What comes after Fordism? 66

PART II: Chapters in the search for a post-Fordist order

$\begin{array}{ll}\text { Introduction to Part II } & \mathbf{8 1}\end{array}$

4. Maturity and relocation in the car industry 83

4.1 Foreign investment, multinational corporations and relocation of industry $\quad 83$

4.2 The theory of relocation and the car industry in the $1970 \mathrm{~s}$

4.3 Production and trade of automotive products in the 1970s 90

4.4 Alternative strategies for the automotive firms 98

4.5 Some final considerations on the theory of relocation 103

5. Teamwork in the West-German car industry and the quality of work $\mathbf{1 0 5}$

5.1 Introduction 105

5.2 New competition and new technologies: a double challenge 107

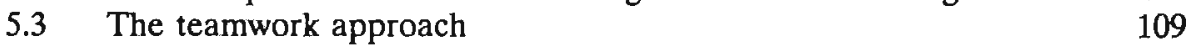

5.4 Consequences for the organisation and for the workers 116

5.5 Environmental influences on the quality of teamwork 118 
6. Technical change and industrial relations

Theoretical reflections on changes in the automobile industry

6.1 Industrial relations and the employment relation

6.2 Unilateral or joint regulation, conflict and consensus

6.3 Technical change and the organization of work

6.4 Technical change and industrial relations in the auto industry

7. Problems and prospects of the West German automotive components industry

7.1 The West German car industry

7.2 The West European automotive supplier industry

7.3 The West German automotive supplier industry

7.4 Changes in the market for automotive components

7.5 Implications for the supplier industry

8. International competition and national institutions The case of the automobile industry

8.1 The Japanese 'threat' 165

$\begin{array}{lll}8.2 & \text { Explanations } & 166\end{array}$

$\begin{array}{ll}\text { 8.3 The Toyota production system } & 168\end{array}$

8.4 Toyotism

8.5 The social context

8.6 Learning from Japan 171

$\begin{array}{lll}8.7 & \text { Changing social institutions } & 176\end{array}$

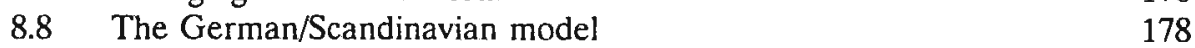

$\begin{array}{ll}8.9 \text { Conclusion } & 179\end{array}$

PART III: New rules: the automobile industry and institutional analysis

9. New rules for the automobile industry?

9.1 Automotive paradise: a retrospective view 183

$\begin{array}{lll}9.2 & \text { Paradise lost } & 187\end{array}$

$\begin{array}{ll}9.3 \text { Car wars } & 199\end{array}$

9.4 The Japanese production system 204

$\begin{array}{ll}9.5 & \text { The industry context } \\ 9.6 & 212\end{array}$

$\begin{array}{ll}9.6 & \text { The new rules of the game } \\ & 218\end{array}$

10. Conclusions and outlook 223

10.1 Beyond lean production: a new mode of regulation? 223

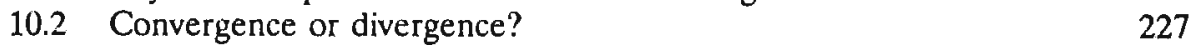

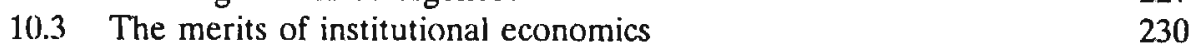

10.4 Outlook: a new regime of accumulation? 235

$\begin{array}{lr}\text { References } & 239\end{array}$

$\begin{array}{ll}\text { Nederlandse samenvatting / Dutch summary } & 248\end{array}$

$\begin{array}{ll}\text { Curriculum vitae } & \mathbf{2 5 0}\end{array}$ 


\section{Preface}

There are times when I envy the colleagues who have become specialists in a specific academic discipline. They can call themselves econometricians, or industrial sociologists, or labour psychologists and identify with the specific concepts, methods and paradigms of those disciplines. Most of the time, however, I am quite happy with the multidisciplinary training I received at the Faculty of Political Sciences of the University of Amsterdam. This book clearly identifies me as a product of that faculty.

When the Faculty of Political Sciences was set up shortly after the Second World War, its founding fathers (I don't believe there were any mothers) chose to create a multidisciplinary program, including economics, sociology, public law, modern history and political philosophy. They hoped, with that characteristic post-war mixture of idealism, optimism and naivety, that future political leaders and civil servants would acquire a thorough understanding of the complexity of social processes, so that they would not make the mistakes that had led to so many disasters in the first half of the century.

In the course of time, the forces of specialization, helped by the pressure to reduce the length of the training program, have pushed the faculty towards a much more traditional approach. Political science is now increasingly defined as a discipline in its own right, with all the dangers of one-dimensionality this entails. I consider myself lucky to have had the opportunity to study there when it was still a truly multi-disciplinary enterprise. The advantages and disadvantages of that approach are very visible in this book: the reader can judge for her/himself. I gratefully acknowledge here especially the teachings of Frits de Jong Edz. and Ger Harmsen, who each in their own way have sharpened my appreciation of the importance of history.

Later, while I was an assistant professor at that same faculty, Robert van der Veen had the difficult task of disciplining me in my first efforts to produce a PhD thesis. He did not succeed, but his criticism of my work and his own critical analysis of marxian economics have been extremely helpful.

The Science Center in Berlin provided an environment that was in many ways quite similar to the faculty in Amsterdam. Created in the early 1970s by the first social-democratic-liberal coalition in Bonn, its aim was to carry out social research of high quality, fundamental in approach, but always with a clear understanding of its social and political utility. It was Andrew Black who hired me there to do research on the automobile industry. Later I could continue work on that industry in a project with Ulrich Jürgens, Thomas Malsch and Knuth Dohse. They all have contributed in many ways to my understanding of the industry. In between the auto projects I worked for Frieder Naschold, who headed a research program on labour 
policy. His own work and his voracious appetite for any scientific contribution that could improve our understanding of the position of labour in society, have deepened my appreciation of a multi-disciplinary approach.

Back in the Netherlands, MERIT has been a stimulating environment. I thank Luc Soete for taking me on board. His interest in non-orthodox, evolutionary economics has created ample opportunities to participate in debate and reflection on the state of economic theory.

Over the past five years at MERIT, I have been able to continue work on the auto industry in various projects and I gratefully acknowledge useful conversations and exchanges with Étienne de Banville, Christian Berggren, Ulrich Bochum, JeanJacques Chanaron, Rainer Doleschal, Aldo Enrietti, Andrew Mair, Mike Parker, Wolfgang Streeck, Rob van Tulder, Giuseppe Volpato, Stephen Wood and many others, who will hopefully forgive me for not mentioning their names. Obviously, I am also indebted to a large number of managers, employees, union officials, members of works councils and others who are professionally involved with the auto industry. They will appreciate that I cannot mention their names here, but I thank them all for the time and knowledge they have shared with me.

Gerd Bräunling has on various occasions over the past 15 years been a valuable colleague and a resourceful friend, who has opened doors and pointed to opportunities that were always rewarding.

Frits Prakke has provided many useful comments and suggestions and I thank him for his patience and encouragement. I feel extremely honoured by the willingness of Robert Boyer, Chris Freeman, Daniel Jones, Luc Soete and Arndt Sorge to be members of the evaluation committee and thank them for their comments and for the inspiration they have given me by their own work. Without the diligence of Silvana de Sanctis, finally, this book would not have reached the printer in time.

Lilo and the children do not want to be thanked, because, as they say, they have not contributed to this book. In a sense, that may be true and I am even tempted to say that it would have been finished earlier without them. In another sense, however, they have contributed so much that I don't know if there would have been a way of writing it and a reason to do so without them.

Ben Dankbaar

Maastricht, November 1992 


\title{
1. Introduction and overview
}

\author{
1.1 The analysis of change in capitalist economies \\ 1.2 Fordism \\ 1.3 Crisis \\ 1.4 System and coherence
}

This book gathers the results of research on various aspects of the automobile industry carried out over a period of almost ten years. At the same time, it presents the fruits of an even longer period of reflection on the contribution of economics to our understanding of processes of economic crisis and change. The result is a book about an industry in crisis, that is also a book about the economic crisis of the 1970 s and ' 80 s. It deals with upheaval and change in the industry that gave off the archetype of Fordism, but it also looks at the demise of Fordism as a development model for advanced capitalist economies.

\subsection{The analysis of change in capitalist economies}

The chapters on the automobile industry that make up the empirical core (Part II) of this book, have been written for various purposes, investigating different questions within the framework of different projects. Here, however, they appear as contributions to a single larger investigation. The central theme of that investigation is the analysis of crisis and change in economic life: what is a crisis, what are its relations to economic development and change, and how can it be explained? These are no doubt very fundamental questions. Economics, the science of economic life, has developed a regrettable preference for the concept of equilibrium. Crisis and change are either ignored or elaborate efforts are undertaken to capture their essence with the tools of equilibrium analysis. But the essence of change is disequilibrium, innovation, the introduction of hitherto untried 'new combinations' (Schumpeter) of knowledge, people, markets and capital gocids. Moreover, following Marx and Schumpeter, discontinuities, disequilibrium, and innovation are the essence of economic life in any capitalist economy. Equilibrium analysis can therefore provide at most a first approximation to a better understanding of economic life. Mainstream equilibrium economics will then be of little help for anyone interested in processes of crisis and change. This argument is further developed in chapter 2 , which then suggests that institutional economics and more specifically the French régulation school provides useful tools for the analysis of economic change.

The analytical approach of the régulation school is taking its starting point from what it perceives as the basic institutions of capitalism. Designating modem 
economies as 'capitalist' is sometimes found controversial. The term is often considered as an opprobium for the western economic system and it was indeed used as such by several generations of Marxists - although not by Marx himself. ${ }^{1}$ Other designations, however, are either less precise, like 'western economies' or 'market economies', or are equally endowed with ideological connotations, like 'mixed economies' or 'free economies'. We shall therefore follow Rosenberg and Birdzell and "use the term capitalism as others have used it: not as defining an ideology properly termed an -ism, but as a convenient term for any of the changing sets of economic institutions that arose in Western European countries during the West's centuries of economic growth" (1986, p.xi).

The regulation school underlines that the term capitalism can indeed refer to different and changing sets of economic institutions. It is equally pertinent, however, in its emphasis on the presence of some basic institutional elements in all capitalist economies. From this perspective, capitalism is considered here to be defined by the following basic elements. 1. Means of production (land, buildings, equipment, raw materials) are mostly privately owned. 2 . The ownership of the means of production is divided unevenly over the population to the extent that a large part of the population owns hardly any and has to offer its capacity for labour to the owners of the means of production in order to make a living. 3. Production which results from this combination of labour with the means of production is aimed at an anonymous market, i.e. capitalism is 'generalized commodity production', which implies that potentially at least there is always competition between suppliers for the favours of customers. 4. Generalized commodity production also implies that some kind of general equivalent, i.e. money, will be available to express the exchange value of all traded commodities. As the means of production can be privately owned and traded, they also have a monetary value, which is called capital. The name capitalism therefore is a more precise designation than 'market economy', which may cover various types of ownership of the means of production.

\subsection{Fordism}

The chapters on the automobile industry in Part II of this book investigate various processes of change taking place in that industry during the past decades. They look at patterns of trade and relocation, the rise of new competitors on the world market, the impact of new technologies and the introduction of new production concepts. In each case they find that these processes of change cannot be explained without reference to various institutions, rules and laws, habits and models, that govern the behavior of the actors in the industry. Relative factor prices turn out to be less important in the explanation of trade patterns and location decisions than the trade and industrial policies of developing countries. New competitors do not grow on their own strength, but are nurtured and

\footnotetext{
${ }^{1}$ Marx speaks of capital, capitalists, the capitalist mode of production, but not of capitalism, presumably because he associated an expression ending on -ism with a set of ideas, a belief or an ideology.
} 
protected by state regulations. The impact of new technologies cannot be understood without reference to the prevailing system of industrial relations. The adherence to new production concepts is highly influenced by the functioning of the educational system.

At the same time, however, it is found that in the period under investigation these institutions, laws and regulations are themselves also subject to change. Governments change their trade policies, unions and employers come to new agreements, new organizational models impress themselves on the minds of managers. Why, how and under what circumstances can 'the rules of the game' be changed? The chapters on the automobile industry provide some partial answers to these questions. A complete answer, however, cannot be given within the framework of a single industry, because many of the institutions that govern behaviour in one industry are also present in other industries. Even a large and dominant industry as the automobile industry cannot be considered apart from its manifold ties to the rest of the economy and to society at large.

Chapter 3, using the concepts developed by the régulation school, points to the logic behind the institutional changes that are taking place in the capitalist world since the early $1970 \mathrm{~s}$. It is argued that this period represents a period of crisis for the successful post-war institutional order. Postwar capitalism was characterized by the rapid diffusion of various elements of the American model of mass production, often designated as 'Fordism'. Fordism is associated with the production of large quantities of standardized consumer goods in highly mechanized production systems with a high division of labor. Mass production doesn't make sense without mass consumption. Capitalist economies had to develop ways of generating demand for the goods they were producing. In the course of time, Fordism became the name not just of a production system, but of a set of institutions that allowed for mass consumption and continuous economic growth in the post-World War II period: institutions like industrial unionism, wages rising with productivity, social security ('automatic stabilizers'), the Bretton Woods system, Keynesian fiscal policies, GATT.

The institutions of Fordism provided for unprecedented economic growth in the 1950 s and ' 60 s. Compared to earlier periods, capitalism seemed to have developed ways of avoiding severe business cycles and of sharing the fruits of economic growth with large parts of the population. By the early 1970 s, however, Fordism had run its course, or so it is argued. Growth rates went down, unemployment reappeared, and the old recipes for action didn't work. The various forms of stagnation and instability that have become visible in North America and Western Europe since the early 1970 s, can be considered to constitute the 'crisis of Fordism'. Slowly, it became clear that new recipes, new rules and new institutions had to be developed. 
Institutional economics (chapter 2) and the analysis of Fordism (chapter 3) provide us with the tools to read the chapters of Part II in a different way: not just as studies of change in the automobile industry, but studies of the crisis of Fordism, as chapters in the search for a new institutional order that can take the place of Fordism.

To characterize the past two decades as a period of crisis for the capitalist economies is as controversial as calling them capitalist. In modern economic thought, the concept of crisis has become unfashionable. It is associated with a severe economic downturn and prolonged economic malaise. In such cases, modern economics prefers to speak of recessions and eventually of a depression. Outside business cycle theory, the word crisis is often used to describe an aspect of structural economic change: the crisis of shipbuilding, the crisis of coalmining. In this book, the concept of crisis is used in the classical sense of decision or turming point. It doesn't so much refer to the relative severity of an economic downturn nor to the decline of a specific industry but to related changes in economic and social organization. The concept of crisis designates a period in history, where economies and societies enter a new development path, characterized by new regularities, new rules and new organizational forms. A crisis may be accompanied by economic depression and structural change, but essential is the development of new institutions that govern economic behavior.

In institutional economics, economic activities are seen as being governed by a complex set of institutions. These institutions are the historical forms of the basic social and economic relations of capitalism. They provide as it were the rules of the game for the economy. Under 'normal' conditions these rules ensure regular growth (accumulation) and a continuous reproduction of the economic preconditions for growth. Economic crises arise if important categories of economic actors cannot survive under the current rules, i.e. if the conditions for 'reproduction' are no longer ensured. Efforts will then be undertaken to change the rules. If the system is to survive and to find back to regular growth, new institutional forms will have to be agreed to (willingly or not) by all actors concerned. A crisis can therefore also be described as a process of search for new institutional forms.

A general economic crisis is naturally reflected in developments within a single industry. On the other hand, a general crisis is also an expression of structural change in individual industries and cannot be seen as preceding these changes, let alone as causing them. In that sense, this book is concerned with capitalist dynamics from the perspective of an industry. The industry under investigation is, of course, not just any industry, but one that has dominated Western capitalist development throughout the twentieth century. 


\subsection{System and coherence}

In the final part of this book, the empirical and the theoretical strands of the argument are brought together. There is first a summarizing chapter on the crisis of Fordism in the automobile industry. It deals extensively with the question if Japanese production methods and organizational models can guide the industry into a post-Fordist era. A final chapter looks at the wider ramifications of the search for post-Fordist arrangements and reflects on the usefulness of institutional economics in understanding economic change. It is argued that an analysis of recent economic history along the lines of the regulation school provides us with a fruitful perspective on ongoing economic and social change. The analysis is not deterministic. It doesn't argue that everything had to happen the way it happened. It does show, that there is system and coherence in the seemingly chaotic processes that make up an economic crisis. 

PART I

Economic crisis and institutional change 



\title{
2. Economics and institutions
}

\author{
2.1 Economics and capitalism \\ 2.2 Countercurrents \\ 2.3 Institutional economics \\ 2.4 The régulation approach \\ 2.5 The logic of institutional change
}

For even the most casual observer of economic affairs, the dominant impression is one of change. Entrepreneurship, the growth and decline of enterprises, industries and countries, technological change, new products and new processes: these are the basic elements of economic life. To the uninitiated, therefore, it comes as a surprise to find that the core concept of mainstream economics is not change, but equilibrium. This chapter argues that the emphasis on equilibrium follows from the fact that economists since Adam Smith have concentrated on the market as the only organizing mechanism in the economy. The emphasis on the equilibrating force of the market has led to an increasing level of abstraction in mainstream economics. Economic actors have lost their social identity and time has become a purely logical phenomenon. Crisis and change are not seen as regular elements of the economy, but the result of forces that are exogenous to the economy. As a consequence, mainstream economics has been increasingly unable to deal with problems of disequilibrium, crisis and change. It is argued that an understanding of economic change requires that other organizing mechanisms besides the market are studied. This is what is done by institutional economics. Institutional economics is introduced here as the collective name for the countercurrents in economics, that emphasize the social embeddedness of the economy. Social institutions are seen as necessary supplements to the market. The market itself, moreover, is analyzed as a complex social institution. The inclusion of other organizing mechanisms than the market makes it possible to treat disequilibrium and qualitative change as phenomena that are endogenous to the economy. A recent contribution to institutionalist thought is the French régulation approach. The régulation approach offers an elaborate conceptual framework for the analysis of capitalist economies. For different countries and periods, different institutional regimes have been identified. A difficult problem that still requires further research is the analysis and explanation of processes of institutional change.

\subsection{Economics and capitalism}

Economics as an independent social science was born and grew with the development of capitalist economies. In economics textbooks its date of birth is often identified with the publication year of Adam Smith's 'Wealth of Nations' 
(1776). By that time it had become clear that a new social order had been arising in Europe - and especially in England. The Industrial Revolution was still to come, but a social revolution had already taken place. A new class of capitalists had grown, that had become rich from trading and banking (and as Marx would add: from plundering). With the activities of that class, the economy had become a social sphere that could be considered somewhat apart from the rest of society. In the days of the feudal system, it had not been thinkable to separate the economy from the rest of the social order. In those days, the organisation of production, distribution and consumption was practically fused with the political organisation of society, i.e. with the the mutual obligations of lords and peasants, the teachings and organisations of the church, etc. By 1776 the economy had become so much a separate social sphere that one could think of it as having its own organisation: the political economy.

The capitalists did not call for the creation of a special political organisation for 'their' social sphere, in the sense of a system of representation and legitimate authority. On the contrary, the argument worded by Adam Smith said that the economy already possessed a specific organizing mechanism, that did not require a law making body of some sort. That mechanism was the market. If only the economy would be left alone, the market would take care of its organizational problems. That organization would moreover be highly efficient. An 'invisible hand' would guide economic activities so that they would contribute in the best possible way to the wealth of the nation. Smith's argument was directed against state intervention and more specifically against mercantilist policies that aimed to increase the 'wealth of the nation' by the introduction of various controls on (international) trade. The invisible hand would do a much better job at that. Interventions and controls served no purpose. Instead, everyone (and especially the capitalists) should be given the freedom to pursue their own interests. Without any further bothersome and costly intervention this self-interested behaviour would automatically be guided to contribute to public welfare, or as Bernard Mandeville had already argued in 1714: private vice would miraculously be transformed into public benefit.

Underlying the political economy of Smith was an image of man as a self-interested person. That was not a new concept in political philosophy. In 1651, 125 years earlier, Thomas Hobbes had forcefully presented the world this view of human nature. Man was depicted as possessed by violent 'passions', always willing to cut the throat of another man, if it would bring any kind of gain. For Hobbes, human nature was the main argument in favor of a strong state (Leviathan) that could control and suppress these passions of man. Man should willingly submit himself to these mitigating and ordering powers of the state. This line of thought made Hobbes the philosopher of the absolutist state, that was to develop the mercantilist policies that Smith so despised.' Hobbes can nevertheless, like Smith, be

${ }^{1}$ To say that Hobbes can be seen as the philosopher of the absolutist state, doesn't imply that his work provided legitimacy to the specific absolutist regimes of the 17 th and 18 th century. Hobbes' emphasis on the contractual relation between the state and its subjects would hardly have been acceptable to a Louis XIV. Hobbes does express the general feeling of this era that a strong 
considered a spokesman of the capitalist class of his days. In the midst of the 17th century, after the 30 years' war, the capitalist classes were primarily interested in the creation of larger political units in Europe with more centralized political structures, as these could be expected to promote and facilitate trade. The absolutist state was a support of the trading capitalists in their opposition to the remaining feudal restrictions on trade. Adam Smith opposed the economic policies of the absolutist state, but it should be noted that he was not opposed to the national state as the major organizational unit on the map of Europe. He could take that organizational form for granted. He argued only that the state should keep away from the economy, which should be the exclusive domain of the capitalist class.

In fact, what separates Smith from Hobbes are 125 years in which the memories of the 30 years' war had faded away and the political order stabilized somewhat. As Hirschman (1977) has noted, the unlimited passions of man in a state of nature' that frightened Hobbes into a defense of Leviathan, had become the private economic interests of self-interested citizens in Adam Smith's work. Smith clearly understood, however, that the pursuit of private economic interests could only be expected to contribute to the 'public good', if it was tempered by some self-imposed standards of civilized behaviour. Two centuries later, a renowned follower of the teachings of Adam Smith echoed this feeling, when he noted that societies "in their evolution have developed implicit agreements to certain kinds of regard for others, agreements which are essential to the survival of the society or at least contribute greatly to the efficiency of its working" (Arrow 1974, p.26). In Arrow's main work this recognition of the socialized character of economic man is at most a footnote to the main argument, which focuses on the market as the one and only efficient and welfare-optimizing mechanism for the organization of the economy. It is an important footnote, however, as it shows that a market economy can only function if it is firmly embedded in a social order that somehow ensures moderate and civilized behaviour. As we will see below, this is an important notion in the countercurrent of institutional economics.

Smith's message of the regulative powers of the market is still very much alive in economics. In many respects, however, there is a world of difference between the works of Smith and a modern economist like Arrow. In a process of increasing abstraction, the philosophy of the political economy has been transformed into a 'science' of economics. The obvious scientific model to follow was the one that had already inspired Smith himself. The powerful Newtonian analysis of celestial mechanics inspired the construction of a model of the economy in which selfinterest took the place of gravitation as an eternally moving force. In every market, the search for maximum utility by the consumers and the desire for maximum profits on the part of the capitalists ensure a movement towards market equilibrium at a market-clearing price. General equilibrium economics brought this way of thinking to its logical conclusion. Almost hundred years after Adam Smith's Wealth of Nations, Walras published his 'Elements of Pure Economics' (1874). The whole economy is pictured as a complex network of interdependent markets. It is

central authority would be advantageous to the nation. 
argued, that the same mechanisms that ensure equilibrium on every single market will also ensure general equilibrium. The proof of this point does require some very stringent assumptions about behaviour and the availability of information. 'These assumptions allow for the achievement of instantaneous equilibrium. If there would not be instantaneous equilibrium, disequilibrium in one market would cause disequilibria in other markets (and maybe adjustments in the wrong direction because of false signals) and the achievement of general equilibrium would become extremely unlikely. The meaning of these assumptions is illustrated by the solution that Walras found for the problem of defining a path towards a determinate equilibrium: he introduced an imaginary auction where buyers and sellers announce the quantities they wish to trade at various prices. They continue to do so until they find a price at which the market is cleared. Provisional contracts are then made up, that are carried out only when the stated prices turn out to be the equilibrium prices of the system as a whole.

The 'marginal revolution' in economics that took place in the 1870 s and is associated with the name of Walras (together with Jevons and Menger) allowed for a neglect of real-life equilibrating mechanisms (i.e. of real markets), as it focused attention on relatively small changes and small divergences from equilibrium. It also introduced a large measure of mathematics into economics. Political economy had become economics and economics became mathematics. It is therefore not surprising that by 1935 Lord Robbins was able to amaze the world with a definition of economics that did not contain any explicit reference to such themes as production, distribution and consumption. Instead, economics had become "the science which studies human behaviour as a relationship between ends and scarce means which have alternative uses" (Robbins 1935, p.16).

Robbins' definition is still representative of present-day mainstream economics, which is usually called 'neoclassical', to emphasize both the continuity and the differences with respect to the classical economics of Smith, Ricardo and Mill. Continuity is to be found mainly in the emphasis on the organizing force of the market. But contrary to the classical approach, the market serves to create a general equilibrium instead of economic development. On the market, individuals are not just pursuing their private interests; they are maximizing some (necessarily continuous) function. Last but nor least, in neoclassical theory the distribution of income is nothing more than an aspect of the general theory of price determination, i.e. of the market. The classical economists had special theories for the determination of the prices of the factors of production: land, capital and labour. The determination of these prices, which then entered into the determination of the prices of commodities, provided a link to the social structure and institutions of the capitalist economy and society at large. Without these links, economics had indeed become 'pure' economics.

Hundred years again after the 'marginal revolution' Nicholas Kaldor concluded that "the development of theoretical economics was one of continual degress, not progress: the ship appears to be much further away from the shore now than it appeared to its originators in the nineteenth century. The latest theoretical models, which attempt to construct an equilibrium path through time with all prices for all 
periods fully determined at the start under the assumption that everyone foresees future prices correctly to eternity, require far more fundamental 'relaxations' for their applicability than was thought to be involved in the original Walrasian scheme. The process of removing the 'scaffolding,' as the saying goes, -in other words of relaxing the unreal basic assumptions- has not yet started. Indeed, the scaffolding gets thicker and more impenetrable with every successive reformulation of the theory, with growing uncertainty as to whether there is a solid building underneath" (Kaldor 1972, p.1239, emphasis in the original).

\subsection{Countercurrents}

In the course of these two centuries of degress, there have of course been countercurrents. The first one to mention in this respect is Karl Marx. Karl Marx can be considered the last of the classical economists, but it shouldn't be forgotten that he considered himself a 'critic of political economy', as it says in the subtitle of his main work. Marx was cricital of Smith and his followers because of their concentration on the market. It was not that he thought the market mechanism unimportant - as Sweezy points out (1970, p.53), Marx's law of value can even be considered as a theory of general equilibrium -, but he did not think that a capitalist economy was adequately described by referring to it as a market economy. What he found missing (or failing) in the political economy of his times was a clear "articulation of the market with the rest of the human world" (Therborn 1976, p.106).

Sweezy argues, following Franz Petry, that this problem of articulation is central to Marx's theory of value. The workings of the market lead to the establishment of prices, or exchange values; "hidden behind this, as Marx was the first to see, there is a specific, historically conditioned, relation between producers... (W)e may call the analysis of the former the quantitative-value problem, the analysis of the latter the qualitative value problem. The great originality of Marx's value theory lies in its recognition of these two elements of the problem and in its attempt to deal with them simultaneously within a sing]e conceptual framework" (Sweezy 1970, p.25, emphasis in the original). It is well known by now that the choice of a labour theory of value as the basis for this attempt has led to considerable problems, especially concerning the quantitative-value problem. What deserves to be remembered is the recognition of the articulation problem and the way Marx approached it.

Marx started with the classical notion that equilibrium prices reflect a distribution of income between rents, wages and profits that is logically and historically prior to the formation of these prices. Therefore, the equilibrium prices do not just serve to clear markets, but they also help to reproduce the social order that is underlying them: every class is receiving the income that is implied by its position in the social structure. If equilibrium prices do not allow for the reproduction of the social order, a period of crisis will start which will serve to re-establish that order. The main measure of the health of the capitalist order is the level of profits. Characteristic for Marx's approach is the distinction between the creation of profits 
(surplus value) in the production process (which is therefore at the same time a process of exploitation) and the realization of profits on the market. By the midst of the 19th century it had become clear that capitalism developed in a cyclical way and that periods of growth were followed by crises and depressions. Marx noted that even when the capitalist order seemed intact at the level of the individual firm, with exploitation going on as usual, the capitalists could suddenly be confronted by severe problems in actually realizing their profits, i.e. in selling the products at a profit and adding the latter to their capital. In this perspective, it is somewhat misleading to follow Sweezy in saying that Marx had a theory of general equilibrium. Marx had a theory of markets and market prices, but the equivalent of general equilibrium is to be found in his macro-economic schemes of accumulation, which emphasize rather the tendencies for disequilibrium and crisis in capitalism.

Marx's schemes of accumulation are based on the earlier thoughts of the 18th century French physiocrats, especially François Quesnay. Nowadays, the physiocrats are better known for their emphasis on land (nature) as the source of all value -an insight that was neglected in two centuries of euphoria about the productive powers of manufacturing industry. However, the physiocrats also contributed to economics the concept of the circular flow, based on an analogy with the circular flow of blood that had just been discovered. This concept was taken up by Marx and later by Keynes. The basic idea is simple: total demand and total supply of goods must be equal and the connected productive activities rewarded properly for the flow to remain intact. A fundamental distinction is then made by Marx between capital goods and consumption goods (wage-goods) and the two sectors of the economy where these are produced. Wage earners will only buy consumer goods. Capitalists will buy both consumer goods for their own use as well as capital goods. The new capital goods will allow capitalists to produce more (or cheaper), which requires that demand is adapted accordingly. Marx shows that equilibrium growth (accumulation of capital) is possible, but then argues that equilibrium is unlikely to be maintained for various reasons (especially technical change). Time and again overcapacity and/or overproduction will appear, not as localized problems, but as generalized phenomena, leading to a reduction in the level of profits. A new profitengendering order is established through crisis and recession, in which the power of the capitalists to create unemployment plays a central role. ${ }^{2}$

In the various countercurrents to mainstream (neoclassical) economics, both the special character of the determination of profits and wages (the wage relation) and the cyclical, crisis-riddden character of capitalist economic development are recurrent themes. This is true, as we shall see, for the institutionalists, but also for other unorthodox economists like Schumpeter and Keynes. It is of course not a coincidence that a well-known Keynesian like Joan Robinson called her most important book on capitalist development 'The Accumulation of Capital' (1956), a title clearly remindful of Marx's vocabulary and moreover identical with that of Rosa Luxemburg's most important work on the same subject (1912). At the core

2 The word 'crisis', often used to designate the high point of an illness, comes natural in connection with the biological analogue of the circular flow. 
of the famous controversy concerning capital theory, in which Rubinson played a prominent role, is the finding that the explanation of the rate of profit must be found outside the world of utility maximizing economic actors. Thus, as Harcourt (1972, p.2) has observed, "the neo-Keynesians see capitalist institutions - private property, an entrepreneurial class, a wage earning class - as giving rise to contlicts between the classes. It is argued that the distribution between the classes of the net product (which is itself viewed as the surplus of commodities over those used up in its production) cannot be understood independently of the institutional nature of capitalism."

Al countercurrents in economics point beyond the market to the relevance of other institutional arrangements in capitalist economies, determining the distribution of income, the level of profits and therefore the rate of accumulation. These other institutions often lack the equilibrating properties of the market. Consequently, in the works of these economists disequilibrium and crisis appear as normal phenomena, as the logical outcome of the social embeddedness of the economy. They make clear that efforts to improve our understanding of these phenomena will have to pay attention to the role of social institutions in economic life, i.e. to institutional economics.

Before we proceed with a more extensive treatment of institutional economics, it will be useful to take a brief look at sociology - if only because the concept of institutions is central to sociology. Sociology is much younger than economics. If we take the classical age of economics to have lasted from about 1775 to 1850 , classical sociology came about a full century later. Thus, sociology was born in a time when the problems that had occupied Adam Smith had receded to the background. The main contradictions were no longer between the capitalist class and remnants of feudalism or the absolutist state. The case in favour of a free market economy had been made and it had won. However, a new set of contradictions and problems of social organisation had come to the fore, that came to be known as 'the social question'. Sociology matured in the same decades that the labour movement became a well organized force all over Europe (between 1890 and 1920). That didn't make sociology into a science of the labour movement, but Therborn (1976) has convincingly argued that sociology can be seen as "a study of politics after the bourgeois revolution" (124). "It developed and became decisively established as an attempt to deal with the social, moral and cultural problems of the capitalist economic order, under the shadow of a militant workingclass movement and a more or less immediate threat of revolutionary socialism" (143).

We have noted above, that implicit in the notion of a self-regulating economy is the assumption that the self-interested economic actors are somehow keeping within the limits of civilized behaviour. It can be argued that sociology takes its starting point in precisely these social strictures to explain the origins of social order and cohesion. Sociology doesn't reject the economist's point of the unique organizing qualities of the market mechanism; nor can sociology be seen as an alternative or a reply to economics; it is simply concerned with the problem of social order and cohesion in a society in which the market is already performing 
its miraculous works. By 1900 free competition had shown its ability to clear markets and promote economic growth, but it had also contributed to new social divisions, new demands on the political system, and to a decline, if not outright destruction of traditional bonds and morals that had provided the basis for civilized behaviour in the past. All the classical works of sociology are concerned with the changes in social cohesion ('the great transformation', Polanyi 1978) provoked by the rise of the market economy and its subsequent intensification through the industrial revolution.

To put it very simply, sociologists came to argue that social cohesion depends on the presence of values, norms and rules of behaviour that are shared by all individuals making up society. Such "regulative principles which organize most of the activities of individuals in a society into definite organizational patterns" were called institutions (Eisenstadt 1968, p.410). The Frenchman Émile Durkheim, one of the founding fathers of sociology, called these institutions 'social facts', the basic stuff that society is made of and the starting point for any analysis of it. The sociologist argues that human behavior is (and indeed must be) permanently regulated by collective ideas and morals. At first sight there seems to be a similarity with Hobbes' plea for the state to control the passions of man. But the differences are great. Institutions can be external to the individual, constraining him as for instance by the force of law, but institutions can also be internalized and in fact they often are in the form of deep-seated beliefs, role patterns and social taboos. The implication is that sociology rejects the Hobbesian starting point of man in a state of nature. An analysis of human behaviour has to start with the 'social facts' of institutions. No social activity and indeed no species that we would call human is thinkable without collective, shared ideas.

The problem was that all this seemed to be much more obvious for pre-industrial societies than for the capitalist societies at the end of the 19th century. What were the sources of social solidarity in capitalism? Or was it true that these sources didn't exist and that society was slowly disintegrating? Durkheim tried to answer these questions in his work 'The Division of Labour' (Durkheim 1986, first published in 1893). Although the title seems to refer to Adam Smith, who had presented the division of labour as a basic precondition for economic progress, there is little or no reference to his work. The book was rather, as Lukes (1973, p.140 ff.) has pointed out, Durkheim's answer to the intellectual traditions represented by Comte, Spencer and Tönnies. All three had struggled with the problem of social regulation in an industrial society. Opposing them on some points and using their insights in others, Durkheim makes a distinction between two different cohesive forces: 'mechanical' solidarity and 'organic' solidarity. Mechanical solidarity arises from the similarities and commonalities in social life. Mechanical solidarity is usually enforced by penal law (because the members of society tend to view a break of mechanical solidarity as a break with society). Organic solidarity arises from the mutual dependencies that come with an increasing division of labour and therefore with dissimilarities existing in society. Organic solidarity requires a 'cooperative' system of law, focusing on contractual relations. Organic solidarity increases in importance with the development of the division of labour in capitalism. 
In his diagnosis of the economic problems of his times, Durkheim finds that the capitalist economy tends to destroy the shared values and morals of mechanical solidarity without a sufficient compensation in the form of organic solidarity. As a consequence, the capitalist order is threatened by a lack of morals and social cohesion. Durkheim proposes a corporatist reorganisation of society, which could restore the moral basis of the economy by recurrence to the professional morality of such groups as teachers, military officers, lawyers, etc. (cf. his introduction to the second edition of The Division of Labour, 1902). Thus, Durkheim calls for the new professional groups to save 'society'. He differs here from the socialists who call for the working class to change society, but is closer to an economic institutionalist like Veblen (see further below), who speaks of socialism, but is basing it on the professional expertise of the skilled worker.

Let us recapitulate. Economics as a discipline is based on the analytical separation of an economic subsystem from the rest of society. Basically, this reflects the coming into existence of a separate social sphere, the circuit of markets, where capitalists had acquired a measure of (political) independence. In economic analysis it is assumed that actors in this economic sphere can be considered separate from their other social roles. The market itself is inspiring this abstraction: there, every value is expressed in the abstract language of money. Through the analysis of markets economics has been able to generate some powerful insights into the cohesion and continuity of societies where trade, production and consumption are not co-ordinated ex ante by organized social and political processes. It is one thing, however, to argue that the market is an important coordinating device, it is another to argue that it is and can be the only co-ordinating device in an economy. In neoclassical general equilibrium analysis, the conditions under which this is possible have been identified. As could be expected, it turns out that a pure market economy can function perfectly, if the economic actors are supposed to be non-social. Economic man, as Veblen has observed, "has neither antecedent nor consequent. $\mathrm{He}$ is an isolated definitive human datum, in stable equilibrium except for the buffets of the impinging forces that displace him in one direction or another" (Veblen 1898, p.73).

We encounter here a fundamental issue that is central to the history and development of the social sciences. Two images of man are pitted against each other: on the one hand rational or economic man and on the other hand nonrational or sociological man. Economists reject sociological models of behavior, because these tend to point to external (eventually internalized) determinants of behavior and thereby eliminate choice. Sociologists reject the model of economic man, because its abstract rationality leaves no room for the social, institutional and historical context. Economists emphasize that humans act in the pursuit of their (perceived) interests. Sociologists emphasize that these interests and the perceptions thereof are socially conditioned and that action itself is circumscribed by socially constructed laws, customs, morals, etc.. James Duesenberry has summarized the debate in his famous sentence, that "economics is all about how people make choices; sociology is all about how they don't have any choices to make" (cited in Granovetter 1985, p.485). Although this sentence no doubt catches the spirit of the debate, some additional observations are necessary. At first sight, 
it seems that economic man is indeed free to make his own choices, whereas sociological man is caught in a tight and stifling web of roles and obligations. At closer investigation it turns out that the freedom of economic man is quite meaningless (as noted by Veblen, quoted above): he is simply adapting (maximizing given functions) to information handed to him in the form of prices and has no real choice to perform. The point to be made is, of course, that social science is interested in determinate behavior. Even where choice is emphasized, the outcome should be predictable. This can only be done in economics by assuming all preferences and all possible courses of action individually given in the form of smooth functions. In sociology it can only be done by introducing an "oversocialized conception of man" (Wrong 1961). In essence, this ongoing debate is a debate about freedom. The combination of freedom and constraint is part of every sphere of life. Where this combination is built into theory, the price to be paid is that behaviour becomes at least partly indeterminate. In fact, that is exactly what happens when we start re-socializing economic man.

\section{$\mathbf{2 . 3}$ Institutional economics}

The development of the paradigm of the market by the generations of economists that followed the tracks set out by Adam Smith led to the construction of a fundamentally un-social image of the economy and of economic activities. That image is not only unrealistic, which might be acceptable and indeed necessary in any analytical effort, but also shields from our view the fact that beyond the market, there are various other social institutions that fulfill important functions in the co-ordination of economic activities, i.e. in the solution of the economic problem par excellence. Even markets that are often used as textbook examples of more or less perfect competition (for instance the market for agricultural products - many suppliers and many consumers) can in reality function only on the basis of a myriad of social institutions. Indeed, every market is itself a complex social institution.

The resocialization of economic man is probably the best way to indicate the common aim of the various practitioners of institutional economics. Two approaches can be distinguished in this scientific project. On the one hand it is possible to take the neoclassical model of general equilibrium as a starting point. Institutional economics can then be depicted as the investigation of the consequences of lifting the various assumptions that served to create economic man (the removal of the scaffolding in Kaldor's terms). Everywhere, where the neoclassical economist has made an 'unrealistic assumption', the institutional economist points to social institutions that help solve the problems that arise from the fact that in reality this assumption cannot be made. This refers to such problems as gathering and processing of information, defining goals of action, deciding on a course of action in the face of uncertainty, limited knowledge and limited time, etc. Institutional economists also point out that economic actors do not maximize but use rules of thumb to make up their mind and stick to those rules as long as the results of their action are satisfactory. This approach is associated with the concept of 'bounded rationality' coined by Herbert Simon, the 
behavioralist theories developed by March and Simon, and more recently with the work of Oliver Williamson.

Williamson has started with the simple recognition that traditional neoclassical theory cannot explain the existence of firms. Under the assumptions used in general equilibrium analysis, firms could not exist, but should be replaced by so many contracts between individuals. This problem had already been formulated by Coase in 1937. Williamson (1975) explored it further and argued that the existence of firms could be explained among other things by the fact that transaction costs could not assumed to be zero. In the presence of transaction costs 'hierarchy' (i.e. an authoritarian order like the enterprise) may be preferable to the market. ${ }^{3}$ In later work Williamson (1985) points out that there may be more institutional forms between the extremes of markets and hierarchies.

The 'new institutional economics' (of Williamson) represents a clear advance over mainstream neoclassical analysis. When markets fail, for instance in economies with uncertainties and externalities, "the neoclassical economist does not, as he should, try to explain what alternative sets of institutions would be created to take their place. Rather he attempts to refine and expand the commodity space of the economy so that markets are again feasible institutions" (Schotter 1981, p.151). Instead of dreaming up markets for externalities or contingent quantities of goods, the new institutionalists point to real-life institutions that perform the function of these imaginary markets.

There is, however, a problem in this approach to institutional economics. That problem arises from the fact, that the market has been taken as a starting point. Institutions are being explained in a purely functionalist way. They are there because they are needed to make the market function properly. Institutions therefore always appear as appendices to the market. Under the institutional garment there is still a naked economic man. In the end, the market remains the dominating organizing device. This kind of institutional economics is innovative and educative in its (functionalist) explanations of institutions, but it doesn't provide new insights into the actual functioning of the economy. Moreover, since the institutions are derived from the immutable characteristics of economic man, it will be difficult to proceed from the mere explanation of the existence of institutions to an explanation of their change and beyond that to an understanding of the interrelations between economic and institutional change.

There is another and older approach to the institutionalist problem that takes off from almost the opposite starting point, namely from sociological man. Considering this opposite starting point, 'new institutional economics' is a clear misnomer, as it has little in common with the old institutionalist school. Institutional economics 'old style', which we will hereafter simply call 'institutional économics' or 'institutionalism', starts with an analysis of the main economic institutions of

${ }^{3}$ Transaction costs are caused among other things by the tendency of human beings to cheat and lie if it is in their advantage to do so. The reader may wish to reflect on the influence of the ideas of Thomas Hobbes more than 300 years after the publication of Leviathan. 
capitalism, their history, functions and disfunctions, rationalities as well as irrationalities. The market is no doubt one of these institutions, but does not have priority over others. Consequently, the borderlines between the economy and the rest of society become somewhat diffuse.

Although starting from the 'social facts', institutional economics has tried to avoid the 'oversocialized' conception of man. What we find therefore is an economic actor moving in a world that is structured by various social institutions. Behaviour is guided and structured by these social institutions, but not completely determined. The economic problem of decentralized co-ordination then becomes both simpler and more complex: simpler, because various social institutions provide additional means of co-ordination besides the market mechanism, but more complex because there is now 'too much' co-ordination: there are many, sometimes contradictory rules circumscribing human behavior. As a result, human choice is over-determined and in that particular sense free. Human decision-making is re-introduced into the picture. Instead of logical time and 'choice' by the maximization of well-behaved functions we find processes of learning, adaptation and satisficing, historical time and irreversible change. There is co-ordination, but not equilibrium; there are causes, but no determination; there are rules, but the outcome of the game is open. The indeterminacy of institutional economics is both a strength and a weakness. It is a strength where it points to the reality of choice in economic decision making, not the formal choice of the neoclassical maximizer, but irreversible choices made in historical time. It is a weakness where, faced by overdetermination, analysis can degenerate into ad-hoc explanations and detailed descriptions. In search for a way out of this problem, institutional economics has developed a tendency to concentrate on aggregate outcomes and macro-economic problems.

It lies within the logic of the institutional approach that an economic recession will lead to a debate about the adequacy of various social institutions that hitherto seemed to contribute to the functioning of the economy. It can indeed be argued, that a recession becomes a crisis only when the existing institutions are put to discussion. Eventually some actors may take the initiative and propose or simply create new institutions. New institutions may also gradually arise from less conscious behaviour. The destructive/creative element of crises, the fundamental openness for new directions, appears in the institutional approach as a process of search for new institutions able to guide and co-ordinate economic behaviour.

Institutional economics has two main lineages: the German historical school founded by Gustav von Schmoller (1838-1917) and the American institutionalists, led by Thorstein Veblen (1857-1929). Alhough we bring them together here under the same label, they developed separately and are rooted in different traditions and settings. What they have in common is an interest in history and institutions. Moreover, they were both considered or considered themselves as altemative paradigms in economics, opposed to the general equilibrium economics that emanated from the 'marginal revolution' of the 1870s. 
The German historical school, founded by Von Schmoller, is in a second generation associated with such illustrious names as Spiethoff, Sombart and Weber (Schumpeter 1986, p.807 ff.). In its criticism of the increasingly abstract models of economics based on deductive reasoning, the historical school chose an opposite methodology. Instead of deducting economic laws from a few assumptions about economic man, it proposed the inductive use of historical case studies. The historical school produced a large number of important historical studies of economic phenomena, but it turned out to be difficult to combine these again in a general economic theory. Some impressive efforts to that effect were undertaken by Von Schmoller himself, and also by Sombart and Weber. However, they hardly contributed anything to what had meanwhile become accepted as economics. As Schumpeter notes, they could "convey an intimate understanding of social or of specifically economic processes, a sense of historical perspective or, if you prefer, of the organic coherence of things", but not "articulate theorems" (1986, p.813). A very principled debate arose about the possibility of deriving theoretical concepts from case studies and the carrying out of case studies without pre-conceived theoretical conceptions. This famous 'Methodenstreit' in German social science with Menger and Von Schmoller as the main protagonists was for all practical purposes lost by the historical school - at least in the sense that later followers of these ideas were no longer considered economists, but sociologists or historians. ${ }^{4}$ In the course of the debate both parties tended to take on extreme positions. Von Schmoller went as far as to say that economic laws cannot be formulated. What he probably meant, and what continues to be an important principle of institutional economics, is that economic laws can only be formulated and are only valid for a specific institutional environment in a specific historical context (Dillard 1986).

In the United States, institutional economics is normally associated with the name of Thorstein Veblen, who between 1890 and 1925 laid the foundation for an 'evolutionary' or 'cultural' economics. Although firmly rooted in American philosophical traditions, his approach also shows some remarkable similarities to the German historical school. Veblen criticized the orthodox Marshallian economics of his days for being static and mechanistic. Instead, he proposed to treat the economy as the material aspect of human culture as it is developing in history. For Veblen, pure economic theory could at best be only a first approximation to economic reality. Above the level of pure theory a theory of the concrete evolving economic system would have to be developed. Only then would an adequate understanding of economic reality be possible. In his analysis of American capitalism, Veblen differentiated between 'industry' and 'business'. The former refers to the production of useful commodities, whereas the latter is concerned with monetary values (which reminds of the distinction between use value and exchange value by Marx). Industry is seen to be primarily a question of technology, whereas business is an organisational form. Veblen's specific version of the 'socialist' revolution involved a sharpening of the contradictions between

\footnotetext{
${ }^{4}$ Schumpeter sees no winners and argues that both historical studies and the analytical tools to handle the material are needed, a conviction that is visible in all of his work. But Schumpeter too concludes that "the Schmollerian economist was in fact a historically minded sociologist in the latter term's widest meaning" (1986, p.814).
} 
industry and business to the point that the working population led by technical experts would replace business by a system of workmanship that would concentrate on the production of use values only.

Although institutional economics remained a minority position in American economic thinking, it has had considerable influence on public debate about economic problems. Whereas the German historical school has few followers left, American institutionalism has been carried on by several generations of highly competent and outspoken persons and has kept a sizeable following until today. In the 1920 s and ' 30 s for instance institutionalism was carried forward by John R. Commons, Wesley C. Mitchell and John M. Clark. They were less inclined than Veblen to predict the end of capitalism and its replacement by socialism, but concentrated on institutional changes in capitalist economies, especially changes in the role of the state, the organisation of finance and the rise of large enterprises. Mitchell, who founded the National Bureau of Economic Research (NBER), made important contributions to the empirical investigation of business cycles. After the Second World War the tradition is associated with Clarence E. Ayres, Gardiner C. Means and above all with John K. Galbraith. They have focused on the existence of various kinds of rigidities in the economy (administered prices and wages), based on the presence of major power groups, that need to be somehow controlled in order to achieve the full employment potential of the economy. As we shall see below, some of the ideas and concepts of American institutionalism return in the writings of such radical economists as Piore and Sabel.

There is a clear and logical connection between the explanations of economic order given by the institutionalists and the neoclassical economists and their respective abilities to deal with the phenomena of economic crisis and change. The neoclassical economists have drawn the borderlines of the economy so tight that change can only come from the outside. Inside, there is only the perfect reign of the market. In institutional economics these so-called exogenous forces are part and parcel of the economy. Change and crisis then become endogenous economic phenomena.

The institutional approach has never been able to really influence mainstream economics, which developed along the increasingly abstract, neoclassical trajectory sketched above. Partly this is no doubt caused by the ideological role that neoclassical economics has come to play. General equilibrium theory has become a rallying point of economic liberalism. Institutionalists tend to spoil the elegant picture and the politics of it as well. The institutionalists, however, also have to blame themselves. They have only partly succeeded in their project of 'articulating the market with the rest of human society'. They often concentrated so much on the analysis and description of all those institutions supplementing the market, that they lost sight of the basic paradigm of economics: the co-ordination of economic activities by the invisible hand of the market. It is not that the institutionalists were not aware of the importance and the explanatory power of that paradigm. They found it very difficult, however, to integrate this basic insight with their vision of socialized man and the social embeddedness of the economy. What happened, in fact, is that they left that separate social sphere called economy and never came 
back. The 'new' institutional economists around Williamson may become more influential in mainstream economics (although they too are highly distrusted), because they never left that social sphere - but then, of course, they don't really know what the world outside looks like.

\subsection{The régulation approach}

Recently, a new branch of institutionalism has been developing in France. Rooted in marxian and keynesian analysis, this approach tries to combine the interest in historical research that was so characteristic of the German historical school with more traditional (macro-)economic theorizing on growth and crisis.

The basic features of the French régulation approach have been developed in the course of the 1970s. It is an ambitious effort to find new answers to some of the core problems of classical economics. In the 'travail fondateur' by Michel Aglietta (Aglietta 1979, first published in French in 1976) these are the questions posed: "What forces transform the social system and guarantee its long-run cohesion? Are the conditions and modalities of this cohesion capable of evolution? In what conditions and by what processes are qualitiative changes in the relations of production introduced? Is it possible to identify stages in the development of capitalism and can such an identification interpret the structural crises of this mode of production? Is the present crisis a sequel to other historical changes internal to capitalism, and does it offer a basis for hypotheses about future class struggles?" (Aglietta 1979, p.16/17) A decade later, the marxian vocabulary has become less dominant, but these questions are still the central concerns of the régulation approach, summarized by Boyer as "the general problem of the variability in time and space of economic and social dynamics" (Boyer 1986, p.39). Aglietta starts from the observation that Marx's concepts "are representations of the relationships that structure society, and not systemizations of individual choices. The object of economic theory then becomes the study of the social laws governing the production and distribution of the means of existence of human beings organized in social groups" (1979, p.16). What the régulation approach suggests is that Marx's intentions should be applauded, but that the strategy of fusing economic and social concepts is problematic. What is needed instead are 'intermediate' concepts between the abstract notions of economic theory (the laws of capital accumulation) on the one hand and the basic social relations of capitalism on the other. These intermediate concepts are the institutions that regulate economic behaviour. This is, again, the project of the articulation of the economy with the rest of society.

Even though it may not call itself institutionalist, the régulation approach clearly falls into that category as we have delineated it above. The concept of régulation refers to the existence of institutions, rules and customs that 'regulate' and organize behaviour and thereby ensure the reproduction of an economic system. Following a marxian conception of crisis, régulation also refers to the possibility that a system 
is reproduced (in its essence) by a transformation of the 'regulative' institutions. In its research efforts, the régulation approach has concentrated on the investigation of the development of these institutions in various times and places. This has resulted in a considerable number of historical case studies. Although there are some similarities here with the approach of the German historical school, an important difference should also be noted. The régulation approach does have a conceptual framework that serves to guide these case studies as well as to organize and combine their results.

Apart from the obvious influence of (marxian) economic theory, the régulation approach also shows the impact of other lines of thought. The use of the word 'régulation' points to an influence of systems theory. Debate about the insights provided by systems theory in the early seventies circled around the notion of the reproduction of a social system through human action that is guided by norms and 'rules of the game' (Hübner 1989, p.28). ${ }^{6}$ Economics, of course, had always represented the economy as a self-regulating system with the market as regulative device. Sociology on the other hand had defined institutions as 'regulative principles' (cf. Eisenstadt's definition cited above). Systems theory suggested to combine the two, to enlarge or replace the market by a broader notion of regulative institutions - as indeed had been done before by the various streams of institutional economics. In the French environment of the early seventies we may also point to the influential work of Pierre Bourdieu, who introduced the notion of 'habitus'. The 'habitus' is the mental structure with which humans approach and understand their social environment. It consists of the basic schemes that enable us to think, perceive, evaluate and act. These basic schemes are transmitted in the family, in school and more generally in (early) social life. It is 'habitus' that provides cohesion to society: the existing order is time and again reproduced by the actions of individuals, because they have internalized that order; it is reproduced in their minds as well as in their acts. Consequently, the book in which Bourdieu first developed the notion of 'habitus' is called 'La Reproduction' (1970). ${ }^{7}$

It should be clear by now that the French régulation as used here has nothing to do with the English 'regulation', which is usually associated with state intervention and was widely debated in the 1980 s under the heading of 'deregulation'. Theorists of the régulation approach are not necessarily proponents of state regulation. As

5 "Les invariants ne peuvent se reproduire qu'a travers des alterations permanentes particulièrement sensibles dans la longue période- de leur forme et de leur articulation précises" (Boyer 1986, p.49).

${ }^{6} \mathrm{~A}$ contribution that has been concerned with the same problems and has remained closer to systems theory is that by Burns et al. (1985).

7 Generally, the regulation theorists have refrained from formulating a theory about the translation of institutions into individual behavior. Lipietz. seems to be the only one who has made a fleeting reference to Bourdieu (Mahnkopf 1988). The question why economic actors are prepared to play the economic game by the rules (institutions), which is central to the sociological analysis of institutionalization, does not enter the regulation problematique (see also section 5 of this chapter). 
to remind of this difference, we will continue to use the French word, when we speak of 'régulation approach' and 'régulation theorists', but for easy reading we will otherwise use English expressions like regulation, regulative and regulate, which then will have a 'French' meaning, as will be clear from the context.

Marxian economics has been a major source of inspiration for the régulation school, although more so in the beginning (Aglietta 1979) than in later contributions. In Aglietta's work régulation is presented as the institutional and historical form or concretization of the categories that Marx had developed in his theory of the capitalist economy. In effect we have here a two-tiered theory of reproduction: the system is reproduced in the abstract, as an economic system, through the law of value, but it is also reproduced in a specific historical form through the workings of regulative institutions. The abstract economic laws that Marx had derived for capitalism in general, are realized through the workings of specific institutions that regulate economic behavior in a specific historical environment. Hübner (1989) notes, that in later contributions historical laws are no longer considered as elaborations or expressions of economic laws. Instead, economic laws are replaced by historical laws. In this perspective the concentration of régulation theorists on institutional forms and their development over time has led them to re-invent the famous Von Schmoller finding, that economic laws do not exist. ${ }^{8}$

Régulation theorists would probably be more inclined to say that economic laws do exist, not as eternal laws, but only in a specific historical context. Taking their starting point in economic theory, they have in effect developed a hierarchy of 'intermediate' concepts and levels of analysis, starting with capitalism as such and ending with concrete historical development. Marx's schemes of accumulation remain important also in the later contributions of the régulation approach

8 Hübner (1989) deplores this development and blames it on the fact that régulation theorists have in their majority abandoned the use of Marx's theory of labour value. By abandoning Marx's value theory, he argues, the régulation theorists have given up the notion of economic laws that are valid for capitalism in general. I am not entirely convinced that this is true. It is true that the régulation theorists so far have looked for economic laws mainly within the framework of specific regimes of accumulation that are considered typical for specific historical periods (see further below). In that particular sense these laws can be called 'historical'. However, it is not impossible that some economic regularities turn up in every regime of accumulation. These could then be considered as 'laws of motion' of capitalism in general - and the related institutions as the specific historical forms in which these laws are realized. If no such regularities across regimes are found, the notion of general economic laws can be rejected. What is indeed rejected is the derivation of specific economic laws from a few defining characteristics of capitalism, without recurrence to observable economic data. The endless debate about Marx's own formulations of general economic laws, like the tendency of the rate of profit to fall, suggests that it may be quite useful to give up this kind of efforts to find general laws. In Marx's formulation, neglecting for the moment the problem of translating values into market prices, the actual realization of his law depends on the ineffectiveness of counteracting tendencies. These can stop and even reverse the tendency of the rate of profit to fall. Obviously, this law cannot be disproven, since it allows for every possible movement of the profit rate. Some régulation theorists have presented their work as an effort to incorporate the (historical) forms of 'counter-acting' tendencies in a historical/specific formulation of the law that is at least open to empirical investigation and refutation. 
(although often in a keynesian or kaleckian disguise), but they are treated according to what they are, i.e. as abstract conceptualizations. As we shall see, they are primarily used to define various possibilities for macro-economic equilibrium between supply and demand, production and consumption.

The analysis starts with the marxian identification of capitalism as a specific historical mode of production, characterized in approximately the same way as we have done above (Chapter 1). Capitalism is defined by the prevalence of market exchange relations, based on the use of money, and by specific relations of production, based on the separation of the workers from the means of production. The first intermediate concept is that of the accumulation regime. Marx had shown that some stringent requirements have to be fulfilled before accumulation can run smoothly. The régulation theorists start from the historical (rather unmarxian) finding that accumulation has indeed been running quite smoothly (only interrupted now and then by more or less cyclical recessions) over extended periods in the history of capitalism. They then define a 'regime of accumulation' as "the ensemble of regularities that ensure a general and relatively coherent accumulation of capital, regularities in other words, that allow an absorption or spreading over time of the distortions and disequilibria that arise permanantly from the process itself" (Boyer 1986, p.47). These regularities can be compared to Kaldor's 'stylized facts', with the important difference that they may include not just historical constants, but also long term trends. Such regularities would include for instance trends in mechanization and in the rate of change of labor productivity, the time horizon used for the evaluation of investment projects and for management activities in general, the division of income between various classes or social groups and the composition of social demand in relation to the development of production capacity. They may include the modalities of exchange between capitalist and noncapitalist parts of the economy, if the latter play an important part in the economy under study. As in Kaldor's work, these regularities form the building blocks for the set of equations, a simple macro-economic model, that represents a specific regime of accumulation. The identification of important regularities is a matter of economic historical research, organized around the concepts of mode of production and regime of accumulation. Historical research suggests that various different 'ensembles' of such regularities can be identified, that constitute as many different regimes of accumulation. Thus, the mode of production can reproduce itself through various distinct regimes of accumulation. Boyer emphasizes that the unstable character of the accumulation proces is not eliminated by a regime of accumulation, but only moderated. In fact, recurrent economic recessions and cyclical movements can be an integral part of the adjustment processes of every regime of accumulation. Nor does a regime of accumulation guarantee stability for ever, as the regime will itself develop and 'deepen' over time, calling forth structural crises.

At least three historical regimes of accumulation are distinguished in the history of capitalism. First there is extensive accumulation, characterized by capital widening investment, slow growth of productivity, a short time horizon in capital formation, a secondary importance of consumption demand in total demand. Wages are moving with the business cycle. Most workers are supplementing their 
wages by the produce of their own garden. This regime is associated with France in the first half of the 19th century. Secondly, there is intensive accumulation without mass consumption. Here we still have more capital widening than deepening, but productivity is rising because of (taylorist) reorganisation of work. Where investment is connected to new techniques, the time horizon in capital formation tends to lengthen somewhat. Wages are becoming resistant to downward movements and more and more workers have no other income than their wages. This regime has been identified for France and the United States in the period between the two world wars. Finally, there is the regime of intensive accumulation with mass consumption. Mechanisation is increasing and productivity as well. The time horizon in capital formation is extending over several years now. The division of income between profits and wages is regulated by collective agreements. Consequently, mass consumption becomes an important dynamic part of total demand. Markets and needs become internationalized. This is the regime of Fordism, prevalent in Europe and the United States after 1950, about we will have more to say further below.

A regime of accumulation is nothing more than a set of economic regularities. In principle, one could think of other regularities and develop a whole series of possible regimes of accumulation. The three regimes just mentioned were defined and so to speak 'composed' on the basis of historical research. They show that capitalist accumulation can take on different forms, with different dynamics, different growth rates and a different distribution of income. The appearance of these regularities now has to be explained. This is where the régulation approach introduces the concept of 'institutional form'. An institutional form is a codification of one or more fundamental social relations (Boyer 1986, p.49). At the source of the regularities that allow for a more or less regular accumulation of capital over a period of time, are the specific forms that capitalist social relations have taken in that period. Boyer identifies five such relations that take on specific institutional forms: the so-called money relation (referring to the relation between the monetary and the real sphere of the economy, i.e. to the organisation of the monetary and financial system); the wage relation (referring to the division of labour, the determination of wages, consumption patterns); the character of the competitive relations between firms; the relation between the state and the economy; and the relation between the national economy and the international economic system. Obviously, these relations are directly derived from the defining characteristics of capitalism, i.e. they are the characteristic social relations of capitalism.

${ }^{9}$ A Keynesian source for the distinction between the extensive and intensive regimes of accumulation is again Nicholas Kaldor. He has pointed out that "(I)n the early stages of capitalist development, when productivity per man is relatively low, ... the Marxian scheme operates: wages remain at subsistence levels, despite rising productivity per man. But as productivity and surplus value rise, a point must be reached sooner or later, when the surplus value equals or exceeds the profit indicated by the Keynesian formula: from then onwards the share of profits ceases to rise and real wages begin to rise, pari passu with the rise in productivity" (Kaldor 1980, p.256; originally published in 1957). The 'Keynesian formula' referred to says that the share of profits in income $(\mathrm{P} / \mathrm{Y})$ is determined by the ratio of investment (I) to output and the capitalists' propensity to consume (c) out of their income: $\mathrm{P} / \mathrm{Y}=\mathrm{I} /(\mathrm{Y}-\mathrm{cY})$. 
The wage relation is considered to be the key relation in the capitalist mode of production. Changes in this relation serve as the main criterium for the periodization of capitalism by the régulation approach. ${ }^{10}$ The wage relation is a relation of exchange between capitalists and workers. As such, it refers on the one hand to the efforts that workers have to bring and on the other hand to the wages they receive in return. The various aspects of this exchange can be grouped in three categories: $a$. the use of labour power in production : the organization of work, the qualifications required, length of the working day, policies of hire and fire, retirement age; $b$. the procedures in use for the determination of wages: organization of the labour market, negotiating rules, role of unions and of state legislation; and $c$. the reproduction of the working class: consumption patterns, the presence or absence of non-capitalist means of reproduction (e.g. food from own garden), the presence or absence of unemployment benefits, pensions, sickness payments and other forms of social security. The basic characteristics of the wage relation are often summerized in what are called the production norm and the consumption norm, referring to categories a. and $\mathrm{c}$ mentioned above.

The institutional forms guide, shape, and constrain individual behavior. They consist partly of internalized social norms, partly of laws and regulations enforced by the state and partly of social contracts and compromises, achieved after negotiations. In fact, without these conventions, norms, laws, rules and regulations, the economy and indeed even the simplest market could not function. The various institutional forms have to fit together. The fit may not have to be perfect, but the institutions should not require blatently contradictory behavior on the part of the economic actors. A specific (historical) set of institutional forms is called a 'mode of regulation'. A mode of regulation consists of all the institutional forms that ensure the dynamic compatibility of decentralized economic decisions, without requiring that the economic actors have internalized the exact principles of adjustment of the whole system. It forms the basis for a continuation of the prevailing regime of accumulation and for the reproduction of the basic social relations of capitalism (Boyer 1986, p.57). Different regimes of accumulation will be associated with different modes of regulation. However, it is possible that different modes of regulation can result in the same economic regularities associated with a specific regime of accumulation. The régulation approach therefore introduces yet another concept, the 'mode of development', to refer to the specific historical combination of a regime of accumulation and a mode of regulation. ${ }^{11}$

${ }^{10}$ The regulation approach differs here from the Schumpeterian theories that emphasize the importance of different basic technologies and also from such marxian and non-marxian periodizations that are based on changes in market structures and the role of the state.

${ }^{11}$ Lipietz (1987) has introduced the concept of a 'technological paradigm' as a third element of the mode of development. The status of this Schumpeterian concept within the regulation approach is unclear. One would think that eventually existing technological constraints and requirements would appear as institutional forms, i.e. as institutions, norms, rules of thumb, etc., as far as they are economically relevant. 
Modes of regulation necessarily have to be defined in historical time and space. Every national economy is liable to have a (somewhat) different mode. For France, the régulation theorists have identified only three modes of regulation, which they call ancient (à l'ancienne), competitive and monopolist respectively. The choice of the last two names is somewhat unfortunate, because it reminds of the distinction between competitive capitalism and monopoly capitalism that already has a large tradition both in marxian and non-marxian analyses. This distinction is based only on the characteristics of the inter-capitalist relations, whereas the mode of regulation refers to a much wider range of institutional arrangements. The change from competitive to monopolist regulation is associated with the transition from extensive to intensive accumulation. Central to both are changes in the wage relation, i.e. in the norms of production and consumption. In Aglietta's analysis changes in these norms are closely related to changes in the competitive relations between capitalists and in that light the use of such designations as 'competitive' and 'monopolist' may be considered acceptable.

This conceptual framework can now be used to develop a typology of crises. Apart from crises that may result from some accidental non-systemic cause (a war, a flood), Boyer distinguishes three crises. First there are the simple cyclical crises that are an integral part of regulation within a specific development mode. These are the crises that solve some of the tensions and instabilities that arise in the course of an expansion phase in the economy. They set the stage for recovery and further expansion without affecting the prevailing institutional forms. The mode of regulation may, however, influence length and depth of business cycles. The other two types of crisis are structural or 'grand' crises. They arise from contradictions within the mode of development. On the one hand there are crises of the mode of regulation. The prevailing institutional forms turn out to be unable to produce or re-produce the economic behavior that would keep the regime of accumulation going or contribute to its recovery. A crisis of the mode of regulation may arise from external or internal shocks in the sense of new economic facts that cannot be dealt with by existing institutions; it may be caused by social-political struggles that put an end to institutionalized compromises; but they may also arise from the actual logic of the prevailing mode of regulation as it is becoming 'mature' and rigid over time. Crisis in the mode of regulation may arise from any of the basic institutional forms and may then spread (or not) to others.

On the other hand, there is the possibility of a crisis in the regime of accumulation. Here, the problem is not that economic regularities are no longer produced, but that the regularities no longer guarantee a further accumulation of capital, for instance because they do not allow a restauration of profit rates. This can be likened to a macro-economic model with defined parameters that performs quite well in predicting economic developments for say 2-3 years and then starts to produce extreme predictions, even though the parameters remain unchanged. Whereas a crisis in the mode of regulation may be (at first) partial, restricted to one or two institutional forms, a crisis in the regime of accumulation calls into question the whole mode of development. If accumulation cannot be achieved, different economic behavior is required and a search will start for new institutional forms to ensure that this kind of behavior is forthcoming (see below). In practice, 
it will not always be easy to distinguish a crisis in the mode of regulation from a crisis in the regime of accumulation, because both will involve a questioning of existing social arrangements. For the sake of completeness Boyer points out that there is in principle of course an even higher level of crisis, which is the crisis of the mode of production, when the defining social relations of capitalism can no longer be upheld. He points out that it is one of the gains of the régulation approach over traditional marxism, that it is no longer necessary to associate every structural crisis with a crisis of the mode of production.

What we have presented so far is a quite elaborate conceptual framework. These concepts help to organize observations and to guide research. The concepts by themselves, however, do not make a theory. It lies within the logic of the approach, that theories about the functioning of an economy are formulated against the background of a specific mode of regulation, i.e. for a specific national economy. Concretely, such theories would have to deal with the exact relations between certain institutional forms and the economic regularities that make up the regime of accumulation. The régulation approach has indeed produced quite a few detailed historical case studies of individual national economies. Besides that, some efforts have been undertaken to develop models of the different regimes of accumulation on the basis of these historical case studies. No doubt, much remains to be done in this respect. However, most régulation theorists have in fact been occupied with the opposite problem: the inadequacy of existing institutional forms to ensure a regular accumulation of capital. The crisis of the 1970 s is seen as a crisis of the mode of regulation (sometimes even of the regime of accumulation). Consequently, the current situation is analyzed as being indeterminate and open for the creation of new institutional forms.

A lot of thinking has been concerned with the possible shapes of these new institutional forms. The conceptual framework of the régulation approach helps to identify the necessary building blocks, but it doesn't say very much about the process of transformation. It has been coined to describe a functioning mode of development, not one that is in flux. In that sense, Verhagen (1990) is right, when he concludes that the régulation approach offers only the possibility of a static comparison between two modes of development and no theory for the process of transition between the two. It should be noted, though, that this is to some extent the result of a conscious choice by the régulation approach. A crisis is defined as a situation that is fundamentally open, providing room for creative acts, new compromises and new norms. There can be no theory for the choices made at such historical crossroads. That doesn't mean, however, that nothing at all can be said about the growth and creation of new institutional forms. A situation may be open, but some outcomes are more likely than others. It should be possible to derive some insights concerning possible developments from the analysis of functioning modes of development, especially from the development of various institutional forms. The germs of new institutional forms will usually be visible in the old forms. Also the analysis of past crises may provide some insights into the dynamics of transformation. The final section of this chapter is concerned with this problem of institutional change. 
Boyer emphasizes that the examples of American institutionalism and the German historical school have shown that it is not sufficient to simply prove that institutions are important. It is necessary to explain the logic of development of the institutional forms: a logic, that is on the one hand more than a simple epiphenomenon of the logic of the market, but on the other hand doesn't deny the spontaneous equilibrating force of the market (1986, p.129). Only if the institutional forms have an explanatory power of their own for observed changes in economic regularities, is it necessary for economists to get involved with them. The régulation approach therefore has to move beyond a 'static' description of a functioning set of institutions towards its development over time in conjunction with economic development.

Basically, two approaches of the logic of institutions can be found in the literature. The first looks at the functions of institutions and tries to provide an account of their creation or at least a justification of their existence on account of these functions. At the beginning of this type of analysis stands a problem, that calls for an (institutional) solution. The second approach investigates the development of given institutions over time, their 'maturing' and eventual decline or transformation. The logic of creation and the logic of development may seem to be complementary, but the perspectives are quite different. Whereas the one is searching for an 'optimal' institution to solve a given problem, the other is looking at an institution that may be or may have been functional to the solution of some problem, but can contain disfunctional elements as well, as both the problem and the institution are changing. The two require quite different concepts, because if an institution is changing, it must be defined how much or in what dimensions it may change without becoming a new institution. As will be clear from the argument so far, the régulation approach is more interested in the second type of analysis than in the first. The régulation theorists identify the 'maturing' of a mode of regulation and its individual institutions as a possible cause of crisis. Some kind of understanding of the process of maturing will in time have to be produced. Crises, however, can lead to fundamental changes in institutions and to the creation of completely new institutions. Some insights into the 'logic of creation' may therefore be useful as well. An important contribution on this topic has recently been developed from the perspective of game theory.

Game theory has removed itself quite some distance from the games ordinary people play. In normal life, playing games usually involves the learning of rules and often necessitates the presence of a referee who sees to it that everybody sticks to the rules. In game theory, a game is defined by the actions available to the players and by the payoffs associated with each action for each player, depending on the actions of the other players. One could say that in game theory the rules are so strict that only a limited number of actions remain open to each player. Because of that, the course of the game remains tractable. Choice is limited. This is why mainstream economists are attracted to game theory. In real life games, the rules leave so much room for choice that the course of the game and its outcome cannot 
be predicted. That has made games a favorite object of study for sociologists and anthropologists.

Schotter (1981) has applied the conceptual apparatus of game theory to the problem of explaining institutions. He makes a distinction between two explanations of the origins of institutions, which he calls the 'collectivist' and the 'organic'. The former he associates with the work of the American institutionalist Commons and the latter with that of Carl Menger, the opponent of Von Schmoller in the 'Methodenstreit'. In the collectivist interpretation, institutions are the outcome of conscious collective action of rational economic agents. Institutions are then the result of some process of political planning and/or bargaining carried out by collective actors and/or individuals acting on behalf of collectives. These processes are the subject of theories of bargaining and of public choice. The organic explanation on the other hand sees institutions arising out of the interaction of a myriad of individual economic agents, each pursuing his own selfinterest. Schotter is mainly interested in organic growth through individual action, which he models as a repeated non-cooperative game. ${ }^{12}$ In the course of time, as the game is repeatedly played (i.e. actors face the same situation repeatedly), "the players develop certain societally agreed to rules of thumb, norms, conventions, and institutions which are passed on to succeeding generations of players" (Schotter 1981, p.12). Thus, social institutions are seen as regularities in behaviour that the members of society have come to agree upon (indeed, found 'agreeable') for certain recurrent situations. These institutions may be self-policed (when it doesn't pay to deviate from them) or policed by some external authority. Schotter's point is that many institutions arise from individual self-interested action, without the need for some form of binding contract between the actors.

In Schotter's terminology, institutions arise 'by design', if contracts between actors contribute to their creation (i.e. if the game is cooperative). However, he does provide one example of an institution arising 'organically' (i.e. unintended) in a cooperative game context. This involves a version of Nozick's description of the rise of a 'minimal state' from a state of nature (the Hobbesian problem again!). Schotter argues that a state-like institution arises as an unintended consequence of collective action undertaken to deal with the problem of 'theft in a state of nature'. He admits that this offers a problem of classicifation. And indeed it does, because the 'unintendedness' in this case is debatable. The actors collectively create an authority to deal with the problem of theft. They may not have thought of a state, when they started, but in the end they consciously and deliberately create a state (or something Schotter calls a state). In fact, it seems that this case of institutionalization only qualifies as being 'organic', because "the players did not set out to create it [the state BD] at the beginning" (p.51), even though they did create it deliberately in the course of repeatedly playing the game. One wonders, if every institution that was not designed from the beginning in its final form can be considered to have grown organically. That would make the set of 'designed'

12 A non-cooperative game is a game in which no communication between the actors is possible. In a cooperative game, communication and binding contracts are possible, which allow for a coordination of actions. 
institutions extremely small. A cursory look at existing 'designed' institutions suggests that they seldom function in exactly the way they were supposed to. In that sense, they have all arisen 'organically' from a world full of design and binding contracts.

This discussion points to the importance of the definitions of institution that are being used. Schotter is defining an institution as "a regularity in social behavior that is agreed to by all members of society, specifies behavior in specific recurrent situations, and is either self-policed or policed by some external authority" (11). This definition is based on a definition of social conventions given by David Lewis, with the addition of the possibility of policing by an external authority. Even though he includes this possibility of policing, Schotter explicitly sets his definition apart from the one that defines institutions as (sets of) rules that specify or constrict the behavior of agents in various situations. In his approach institutions are not 'rules of the game', but rather elements of the equilibrium solution of the game. Let me suggest a somewhat different terminology, that may clarify the debate. Schotter (and before him many sociologists and anthropologists and indeed economists like Herbert Simon) has argued convincingly that 'regularities in behaviour', rules of thumb, norms, may arise in a society in the course of time, without an organized conscious process of design, but simply because these regularities are found in practice to be agreeable. I would call such regularities 'conventions' as long as they are self-policed. They become institutions as soon as they begin to be upheld by sanctions (of whatever kind). At that very moment, however, they are more than regularities in behaviour: they become regulators of behaviour. They are no longer identical with behaviour, but separate 'social facts'. They are rules of the game, but in their actual behaviour players may not stick to the rules.

The institutionalization of conventions can take place through codification (the rule is defined precisely so that eventual sanctions acquire legitimacy) or by the simple fact that sanctions are being applied to players who do not follow the convention. In both cases, I suggest, we are leaving the world of non-cooperative games and entering that of collective action. In that sense, Commons is right, when he defines institutions as 'Collective Action in control of Individual Action' (quoted by Schotter, p.4.). It seems unnecessary, however, to see implied in this definition that every institution is created intentionally, let alone 'from the beginning'. I would rather think of institutions as having a complex history in which 'organic' conventions (social inventions) interact with deliberate acts of design (social innovations). After all, it may be useful for heuristic purposes to derive institutions from a non-cooperative state of nature, consisting only of self-interested individuals, but we shouldn't forget that conventions are produced in a society of some sort. That implies that they are produced within a framework of already existing institutions. "Institutions constitute a part of the basic definition of society and are concomitant with the very existence of ordered social life" (Eisenstadt 1968, p.410). Indeed, Schotter's non-cooperative games are necessarily played according to certain rules (implied in the strategies available to the players), including the 'state of nature game'. 
Let me try to combine the concepts just presented with the concepts of the régulation approach. Out of the repeated occupation with specific problems arising in specific situations, social conventions may be developed 'organically' by economic actors. These conventions may become institutionalized, which usually involves a measure of codification. Institutions are conventions backed up by sanctions. A large number of conventions and institutions enter into the organization of a basic social relation like the wage relation. Together they make up what the régulation approach has called an 'institutional form'. Since the various conventions and institutions have different histories and have not been designed in one piece, an institutional form consists of potentially contradictory elements. The growth of an institutional form will therefore be one of constant adaptation, reformulation and (re)construction of its elements, a process that again may be partly deliberate and partly organic. What happens is that a workable (agreeable) set of rules is 'selected' from those on offer through the self-interested behaviour of the various (groups of) actors involved. ${ }^{13}$

An institutional form is therefore always partly 'organic', but since it refers to a well defined and quite visible social relation, it is to be expected that its history will also contain a lot of deliberate design. Various actors may have quite clear ideas about the future institutional forms that they would consider desirable, but only seldom will they be able to realize these forms, because the institutional forms cover relations between actors with sometimes opposite interests, so that the final form will usually be some kind of social contract or compromise. Things are somewhat different in the case of the rise of a new mode of regulation. A mode of regulation may be understood as a 'mosaique' of institutional forms. Not just these forms have to be explained, but also the fact that they somehow fit together and function together. Unlike an institutional form, a mode of regulation cannot be easily connected to specific social actors, groups or organisations. More than in the case of institutional forms, the growth of a mode of regulation will therefore be a time-consuming process of selection and adaptation. In one sentence: institutional forms may be 'designed', but modes of regulation will usually grow 'organically'. "Regimes of accumulation and modes of regulation are chance discoveries made in the course of human struggles and if they are for a while successful, it is only because they are able to ensure a certain regularity and a certain permanence in social reproduction." (Lipietz 1987, p.15; cited by Hübner 1989 , p.146) However, even in the case of a mode of regulation deliberate design is not impossible. The process of selection and mutual adaptation of institutional forms may be sped up and even replaced by conscious 'assembly' on the basis of an inspired vision or a working model available elsewhere in the world. Thus, Keynes' model of the economy helped to understand and re-interpret some of the policies and institutions created in some countries before the Second World War. That made it easier to introduce comparable institutions in other countries later on. Nowadays, we are witnessing a comparable debate about the 'Japanese model'.

13 "D'où une conception mettant en avant un processus de sélection, oscillant entre hasard et nécessité, et portant sur les formes d'organisation. If faut le souligner, cette vision n'est ni un fonctionnalisme pur, ni un darwinisme social déguisé, mais combine en un mélange complexe ces deux références." (Boyer 1986, p.136) 
Explanations and perceptions of this model are influencing the current processes of institutional redesign in various countries.

Now let us shift our focus from the creation of a new institution to the changing of an existing one. In what dimensions can an institution change? If we define an institution as a behavioral rule for a specific situation, enforced by some kind of sanction, then, obviously, institutional change can refer to changes in the rule or changes in the sanctions. A change in the pertinent situation or problem would not be considered institutional change, but that will quite often be the occasion for change. Or, the relevant situation or problem may not have changed at all, but changes elsewhere in the environment make behaviour according to the existing rule inadequate. Changes in a behavioral rule will be caused by generalized dissatisfaction about the results of behaviour according to the prevailing rule. Such changes may be enacted in a formalized manner (the institution may even provide procedural rules for the change of its contents) or experimentally tried out, sometimes in spite of sanctions enforcing the old rule, and then copied by others if successful. They may also be discovered 'by chance'. Note, that this implies that at all times there will be actors who (try to) deviate from the rule. The institution may predict the aggregate behavior of actors in the relevant situation, but individual behaviour remains indeterminate. Indeed, the growth and development of an institution can only be explained, if in practice deviations from it are possible. That is why macro-economic regularities can be explained by the presence of institutions. These regularities are the expressions of 'normal' or average behaviour and allow to treat economic actors as identical. The complementary microeconomics, however, must be based on the fundamental proposition that economic actors are all different. ${ }^{14}$

If sanctions do not work, of course, an institution is all but dead. The 'changeability' of institutions depends on the type of sanctions connected to them and the intensity with which they are enforced. This insight is at the basis of what may be called a hierarchy of institutions in terms of the sanctions attached to them. At the highest level there are social norms and values, largely internalized by the various actors and enforced by social control and individual conscience. At a lower level we find laws and regulations that have been enacted by the state or state agencies. They are enforced by the state, which may or may not require considerable efforts on the part of state agencies, depending on the legitimacy of government and of the particular laws and regulations concerned (and on the values subscribed to by the citizens of that state). At a still lower level we find rules that have been agreed upon by contracting parties after negotiations. They can often be enforced with the help of state agencies, but to a large extent this will not be necessary, because the parties subscribe to a social norm that contracts should be kept. The three levels represent degrees of difficulty in changing these regulative mechanisms: it will usually be easier to change a contractual agreement between a limited number of actors than to enact a new law, that will usually be

${ }^{14}$ In the important work by Nelson and Winter (1982) several models are presented that not only allow for this essential differentiation between economic actors, but also for processes of 'search' for new behavioral rules. 
valid for many more actors. To change a social norm or a pattern of values is something that can hardly be done consciously and is in any case a long-term exercise. Nevertheless, as sociologists noticed already in the 19th century, in capitalist societies it is often less dangerous to break an established social norm than to come back on a signed contract. For an understanding of the questions discussed here, it is important to note, that the sanctions attached to a specific rule may change over time, not just in the sense of becoming stronger or weaker, but aiso in the sense of changing from informal social sanctions to penalties by a court of justice or the other way around. Similarly, institutional forms as defined in the régulation approach consist of a mixture of different types of institutions. Consequently, a change of an institutional form can also consist of a change in that mixture. In the wage relation, for instance, much more is handled by law nowadays than at the beginning of this century. Finally, it should be noted that the enforcement of a rule by sanction requires some kind of organization to administer the sanctions. The 'maturing' of an institution can probably be best expressed in terms of a growing rigidity (maybe even bureaucratization) of that organization.

If we now turn to the problem of changes in an existing mode of regulation, it is possible to discern a certain hierarchical order between the various institutional forms that make up the mode of regulation. The régulation theorists tend to treat the wage relation as the most important social relation of the capitalist mode of production. It is around the institutionalization of different aspects of the wage relation that most social debate and conflict is noted. In that respect, it is maybe more precise to say that the wage relation is potentially more contentious instead of more important than the other relations. In any case, the contradiction of interests between capitalists and workers are usually considered to be more fundamental and more difficult to overcome than those between different capitals (problems of competition and the structure of markets) or those related to the monetary system (conflicts of interest between industrial and financial capital, between capital and the state). After the wage relation, the relation between the state and the economy is probably the most debated basic relation of capitalism. Debate concerns on the one hand such basic issues as the protection and limitation of property rights, but besides that the state also enters into the definition and institutionalization of all the other basic social relations of capitalism.

If we suppose that pressure follows the path of least resistance, it seems logical that in the case of a recession, the less contentious institutional forms and within them the less well-structured and weakly sanctioned institutions will be the first to be questioned. Only if the problems cannot be amended by institutional change at these lower conflict levels, social conflict and structural change really become endemic and the recession becomes an open crisis. Once the crisis is there, changes in some of the less contentious institutional forms may result in other economic problems and other regularities in the regime of accumulation, maybe even in the rise of a new regime of accumulation. This may call for changes in more basic institutional forms. This line of reasoning suggests the following reading of institutional change in the past decades: ongoing accumulation in the 1950 s and ' 60 s is accompanied by changes in the international regime (the articulation between national economies and the world market, e.g. because of decreasing 
tariffs) and gives rise to changes in competitive relations between groups of capital, especially through the growth of transnational corporations. The first serious signs of problems in the accumulation process lead to some fundamental changes in the 'money relation', in this particular case in the international monetary system. After the oil crisis of 1973 (only at that point in time did the word 'crisis' come into widespread use) the failure of crisis policies (i.e. of the relevant institutional forms) produced a debate about a crisis of the welfare state and, later again, about the need for fundamental changes in the Fordist wage relation. Although this is just speculative 'quick history', it does suggest that the notion of a hierarchy of institutional forms in a mode of regulation can serve heuristic and organizing purposes.

As noted above, historical case studies play an important role in the régulation approach. The presence of a common conceptual framework makes it easier to organize, compare and combine these case studies than was the case in the German historical school. Historical research is indeed indispensable, not only for an understanding of the origins of various institutions, but also to generate hypotheses about the relations between these institutions, the forms into which they agglomerate and observed economic regularities. Studies of specific institutions, like for instance the labour contract, may point to specific discriminating factors, like new forms of entrepreneurial organization, new technologies or changes in the labour market supply, that correspond with innovations in the form of the contract. This research must form the basis both for periodizations and for hypotheses concerning the factors contributing to changes in institutional forms.

Before leaving the subject of institutional change, a brief note on politics is needed. Various definitions of 'politics' are possible, but the following is, I suggest, quite uncontroversial: politics is a general designation for all activities aiming at the establishment of authoritative 'rules of the game' for (parts of) society. The implication of that definition is that institutional change is also a political process, at least as soon as we leave the world of purely 'organic' institutions. As soon as we are talking about 'designing' institutions, we are talking about politics. Politics adds the dimension of power to the analysis of institutional change. This has important implications. First, efficiency in performing an (economic) function is no longer the only explanatory variable in a functional explanation for an institution; what must be added is its political efficiency, i.e. its impact on the distribution of the sources of power. Second, the distribution of political power and the rules of the political system must be taken into account to explain the actual historical development of an institution. Third, if institutions are to some extent a function of power relations, then they may change if the power relations change, even if there is no need for change in terms of the economic functions performed by the institution. All three implications point to the problem that real-life institutions will never be purely functional for the economy, but also reflect broader aspects of social organisation, among them cultural, racial or religious divisions. The nonfunctional elements of institutions may in turn have unexpected negative or positive effects on the economy. The 'articulation of the economy with the rest of the human world' is not a one-sided affair. Even if we concentrate on the economy and its institutional forms, we should be mindful of the fact that this 'political economy' 
is part of a larger polity that cannot be neglected, especially not in periods of crisis and institutional change. 


\title{
3. The crisis of Fordism
}

\author{
3.1 Fordism \\ 3.2 The crisis of Fordism \\ the economic breakdown of the 1970 s \\ the regulation approach and the crisis of Fordism \\ 3.3 Others about the crisis of Fordism \\ Schumpeterian theories \\ social structure of accumulation \\ Olson \\ 3.4 What comes after Fordism? \\ information society \\ flexible specialization \\ Toyotism
}

This chapter discusses the economic crisis of the past two decades and the related search for new institutions within the general conceptual framework provided in the previous chapter. We begin with a discussion of the postwar mode of regulation, called Fordism. This will be followed by a brief analysis of the crisis of Fordism and the evolving debate about the inadequacy of its institutional forms. We will then turn to the process of institutional change, with special attention for the following questions. Where will initiatives for institutional change most likely come from? Are any rules available to guide actors in their efforts to change current institutions? Are any 'visions' or practical models available to direct the efforts at institutional renewal? This discussion sets the stage for the analysis of institutional changes occurring in the automobile industry that will be the subject of following chapters.

\subsection{Fordism}

In the régulation approach, the mode of development that has been prevalent in the capitalist world since the Second World War is called 'Fordism'. The name refers to early theorizing on this topic by Antonio Gramsci (1971, written between 1929 and 1935) but above all it refers to changes in the wage relation, i.e. to the practices of mass production and mass consumption exemplified by the methods of Henry Ford.

On April 1, 1913 the workers of Ford's flywheel magneto assembly department were for the first time confronted with a completely new organization of their work. No longer were they expected to put together a complete assembly. Their individual work benches had disappeared. Instead, they had to stand beside each 
other at a long, waist-high pipe frame with a smooth sliding surface on which a whole row of flywheels could be placed. Every worker was instructed to perform only a specific detail of the assembly operation and then push the flywheel to the next worker in the row. That first day at the first assembly line in the automobile industry the average assembly time per flywheel went down from 20 minutes to little over 13 minutes. After some changes (raising the height of the line, because workers had complained about aching backs; lowering the number of workers; and moving the flywheel with a continuous chain instead of it being moved by the workers) the assembly time went down to 5 minutes within a year. Ford's engineers had finally found the solution to the problem that had plagued them since the beginning of the production of the Model $\mathrm{T}$ : the problem of mass production. In 1908 , the introduction year of the Model T, Ford had sold almost 6,000 of them. In 1913 he sold 183,000 and ten years later the top was reached with a production of 2 million units (cars and trucks) in one year. It was the assembly line ('moving the work to the workers') that made mass production of this kind possible (Hounshell 1984, p.247 ff.).

A functioning assembly line requires the timely supply of large numbers of interchangeable parts. In the preceding years, Ford had already perfected the production of these parts, making use of a large number of single-purpose machine tools, many of them designed in-house. The idea of using machine-made interchangeable parts already had a long tradition in the United States and had indeed become known in the industrial world as the 'American system of manufacturing'. The idea had, however, not always been easy to realize with the available machine tools. David Hounshell suggests that 1913 was probably the first time in history that the machine tool industry was capable of manufacturing machine tools that could turn out large amounts of consistently accurate work (1984, p.233). Ford and his engineers were continuously searching for the best available machines and materials. Therefore, even though the idea of interchangeable parts was much older and first efforts at mass production had been undertaken for instance in sewing machines and bicycles, the realization of mass production is a phenomenon of the twentieth century. Henry Ford, moreover, deserves to be remembered for this achievement, not only because it was first realized in his factory, but also because the Ford Motor Company took pride in propagating the idea, kept nothing secret, but opened its doors to whoever was interested.

Just two years before the introduction of the first assembly line in the auto industry, Frederick W. Taylor had published his 'Principles of Scientific Management'. Taylor's star had been rising rapidly in the first decade of the century and even though it lost some of its brilliance in the second decade, the basic ideas of 'scientific management' remained very much alive throughout the century. Taylorism stands for a new, systematic way of thinking about the organization of production by a new, rapidly growing group of professionals: the engineers (Noble 1977). At the core of Taylorism we find, first, a sharp division of labour between management (engineers) and workers, where workers only execute the tasks that have been designed for them by management; and, second, the notion that the best way to execute a job can be determined scientifically, 
especially by 'time and motion' studies. Payment of the worker had to be related to this scientifically determined standard. Moreover, workers were to be selected scientifically, meaning that their skill level should be just enough for the job at hand. As Fordism developed in the same period, the question arises, if Ford's system is more than a practical development of Taylorism. Hounshell argues that indeed there is a great deal more. The Ford Motor Company did have a department for time and motion studies (which would be all the more necessary for the balancing of assembly lines) and of course it did practice a sharp division of labour between management and workers. However, "Taylor took production hardware as given and sought revisions in labor processes and the organization of work; Ford engineers mechanized work processes and found workers to feed and tend their machines. Though time and motion studies may have been employed in the setup of the machine or machine process, the machine ultimately set the pace of work at Ford, not a piecerate or an established standard for a 'fair day's work.' This was the essence of the assembly line and all the machinery that fed it. While depending upon certain elements of Taylorism in its fundamentals, the Ford assembly line departed radically from the ideas of Taylor and his followers." (Hounshell 1984, p.252/3)

Nevertheless, if Fordism had only been a new system of work organization, it would probably never have acquired the fame that it did. Fordism stands not just for mass production, but also for mass consumption. Not only did Ford have the vision of the automobile as a product for the masses, but he also became something like an inventor of buying power for the masses by his widely publicized decision in January 1914 to raise wages to the unheard-of level of five dollars per day. Ford has been quoted as saying later that this had been one of the best decisions in his business career; but that he would have made even more profits if he had raised the wage to six dollars. The notion of a positive relation between high productivity, high wages, mass consumption and high profits was widely discussed in the United States and Europe already in the early 1920s. It fascinated not just managers and capitalists, but also found acclaim among theorists of the labour movement. Although all this seems to suggest that Ford was a 'Keynesian' avant la lettre, trying to create effective demand for his own products, the immediate causes for the five-dollar day were more prosaic. The problem was that workers didn't like to work on the assembly line. Labor turnover reached 380 percent in 1913 and toward the end of the year, the company had to hire almost 1000 men in order to expand its personnel by 100 . There were also growing signs of unionization. The five-dollar day was a smart move that settled all those problems at once. In the course of the 1920 s, when it became possible to get and keep workers for lower wages, Ford abandoned the five-dollar day again.

The régulation theory argues that this lack of commitment to high wages (which of course cannot be held by an individual enterprise unless it has much higher productivity than its competitors) is exactly the problem of the 1920 s that finally resulted in the Depression of the 1930s. What we see in the United States, but also in other countries, is a rapid diffusion of mass production methods and technologies, but there is no concurrent expansion of effective demand for the products thus produced. It was only during and after the Depression of the $1930 \mathrm{~s}$ 
and the Second World War that new institutions developed that, much to the surprise of most observers, ensured economic recovery and growth of unprecedented proportions. These institutions make up the mode of regulation of Fordism. Fordism as a mode of development of post-war capitalism includes collective bargaining between unions and employers, the widespread acceptance of the rule that (real) wages can rise in line with productivity, social security organized by the state, which serves as 'automatic stabilizer' for the economy, the recognition of full employment as a legitimate goal of government policy and of fiscal policy as an instrument to that effect, and the so-called Bretton-Woods system regulating international economic relations. Obviously, Fordism in this sense encompasses much more than the assembly line and the five-dollar day, but mass production and mass consumption are still at the heart of the concept. Mass production was based on mechanization and an enormous intensification of work, as illustrated by the reduction in assembly times on Ford's flywheel assembly line. The regime of accumulation based on mass production has therefore been called 'intensive accumulation'. Without mass consumption, intensive accumulation ended in crisis and depression. After mass consumption was ensured by the new institutions that arose out of the struggles of the $1930 \mathrm{~s}$ and ' $40 \mathrm{~s}$, intensive accumulation turned out to be a much more stable regime than the extensive regime of accumulation of the 19 th century.

The institutional forms of the capitalist social relations in a Fordist mode of regulation differ quite substantially between countries. Although Fordism is seen as originating in the United States, some of its supposedly characteristic institutions have developed in a more elaborate and consistent way outside that country. A few general features of the Fordist institutional forms can nevertheless be identified.

We may begin with the intercapitalist relations, i.e. with market structures and forms of competition. As noted above, the régulation approach has focused on the wage relation as the core relation of capitalism, although in the early work by Aglietta changes in intercapitalist relations also played an important role. Aglietta even used the adjectives 'competitive' and 'monopolist' to denote the 19th century mode of regulation and Fordism respectively. It can be argued that structural changes in the organization of capitalism away from its 19 th century forms began with market structures. At least these were the changes that were widely noted and gave rise to extensive debate about the possibility of an 'organized' form of capitalism (Hilferding). As firms grew bigger and bigger and markets became dominated by a handful of giants, the idea that capitalism could move beyond the anarchy of the market seemed not too fanciful. The formidable capacities for efficient organization that capitalism displayed at the micro-level should now be extended to the macro-level. ${ }^{1}$ Although these ideas turned out to be illusory and based on an incomplete understanding of competition, the fundamental insight that changes in market structure affected the functioning of the economy survived. It

${ }^{1}$ In the marxian tradition these ideas are at the basis of the theory of state-monopolycapitalism that was developed by orthodox communist theorists to explain the post-war development of capitalism. The theory basically argues that capitalism has come to be managed by a coalition between big (monopoly) capital and the state (Boccara et al. 1972). 
is present in much of (post)keynesian thinking in the form of imperfect markets, mark-up pricing, and collective bargaining. Keynesianism didn't try to organize capitalism, but it did treat the economy as a 'manageable' whole. Much of that manageability depends on the transparency of market relations that came with the rise of oligopolistic structures. This is of particular importance in the case of the wage relation (see also below). The idea of wages rising in line with macroeconomic productivity growth practically pre-supposes mark-up pricing and a shift away from pure price competition.

Aglietta has emphasized the marxian distinction between the creation of value in production and its realization in exchange on the market. It is only on the market that the aim of capitalist production, the accumulation of capital, can be realized by the transformation of products (value) into money. This necessity for produced values to take on a monetary form is denoted by Aglietta as the monetary constraint'. I will not enter into the value-theoretical debate related to this concept (Hübner 1989, p.86 ff.). One doesn't have to subscribe to Marxian value theory in order to see that money is the medium that relates disparate economic activities to each other. Money makes a complex social division of labour possible or, as Marx has observed, money allows concrete labour to be transformed into abstract labour. Aglietta emphasizes that money is not a neutral medium, but takes on specific institutional forms that regulate (and indeed constrain) exchange relations. Early mass consumption in the United States was accompanied by the rise of consumer credit. In this case it wasn't Ford but General Motors that first created its own banking institution (the General Motors Acceptance Corporation). Consumer credit and investment credit fed each other throughout the 1920s and temporarily covered up the fundamental imbalances between rising productivity in consumer goods production without a concurrent rise in consumer incomes. The resulting financial crisis led to important institutional changes in the American monetary system and financial intermediaries. A general outcome of the crisis was a strengthening of the role of central authorities in the financial system in all developed countries. The national banking systems, regulated by strong central banks, have played an important role in the controlled expansion of demand over the first post-war decades. How important the role of money and the potential of monetary policies were, remained subject of heated theoretical and political debate between monetarists and keynesians throughout the history of Fordism.

Money and financial institutions are of course also of central importance in the relation between a national economy and its trading partners. From the perspective of international trade, the interbellum appears again as a period of transition. Trade had greatly expanded in the period before the First World War and it expanded again with even greater speed after the Second World War, but the period between the wars is one of stagnating trade and protectionism. There is an important difference, though, between the two periods with expanding trade. Before 1914, in the 'age of imperialism' trade focused on the exchange with countries that could still be considered as basically non-capitalist. After 1945, growing international trade was concentrated on relations between the industrialized countries. Postwar Fordism is not a revival of Imperialism. Burkhardt Lutz (1984) who, following Luxemburg, emphasizes that capitalism must always 
expand into non-capitalist spheres, argues that Fordism is based on the expansion of capital into non-capitalist spheres inside the capitalist countries. This involves the destruction of traditional parts of the economy, like agricultural and handicraft production. However true this may be, no-one will deny the importance of expanding international trade for the rapid economic growth and probably also for the absence of major business cycle movements in the first post-war decades. The diffusion of the Fordist wage relation may be at the basis of that expansion, but trade certainly made the expansion easier. The institutions constituting the system of international trade in the post-war period therefore deserve a prominent place in any analysis of this period. This has been widely recognized and the demise of the Bretton Woods system, as these institutions were collectively called, has often been seen as a first signal that Fordism was running into problems. That signal is usually dated with President Nixon's decision to end the convertibility of the dollar on August 15, 1971. It indicates that this part of Fordism too was, if not an American invention, a reflection of its dominating position at the end of the World War that allowed its vision for a new monetary order to be realized (Spero, 1977; Block, 1977).

The state is a necessary part in every social relation of capitalism, since the state is on the one hand part of the mechanisms enforcing and maintaining capitalist institutions and on the other hand it is the place where capitalist institutions are (re)defined, their limits drawn and their legitimacy created. The state and staterelated processes can therefore be discussed under the various basic social relations identified, but it is also necessary to look at the institutional forms of the state itself as a constituent part of the economy, or rather as an institution governing the relations between the economic and the non-economic. This is especially important in the case of Fordism, as it is generally agreed that the state plays a much more important role here than in earlier modes of development. The Fordist state can be characterized by two distinct post-war developments: the rise of the so-called welfare state and the assumption of state responsibility for macro-economic stability and growth, especially full employment. The institutional forms of the Fordist state show significant differences between countries. Whereas the influence of the Americans and the American model is evident in the other social relations, the Fordist state is much less an American creation. In most European countries the welfare state has developed much further than in the USA. The adoption of a Keynesian view of the state and of fiscal policy came relatively late in the USA and never wholeheartedly (Lekachman 1966). This divergence in state development suggests that intensive accumulation with mass consumption was possible in the United States without explicit supportive and corrective state policies, whereas it was not in most European countries. The explanation for this can be given in purely political terms as has indeed often been done: the strength of the European labour movements and the interaction between these movements and christiandemocratic currents are then supposed to account for the completeness of the European welfare states (Gough 1979). However, it is possible that quite apart from these differences in power structures the economic conditions in the United States during the first post-war decades were so much more favorable for continued expansion, that no political corrections on the functioning of markets were necessary until the 1960 s. 
Both the welfare state and keynesian fiscal policies serve to maintain aggregate demand in the economy in the face of destabilizing fluctuations in capital expenditure. Social security, unemployment benefits, pensions and other transfer payments contribute to mass consumption. Besides that, the welfare state stands for state expenditure and involvement in housing, education and health services. The growth of the 'social wage' reflected by this type of expenditure is of course functional to the regime of accumulation, but it can only be explained by reference to the political processes involved in the construction of Fordism.

Let us now return to the wage relation in Fordism. Mass production is the paradigm for the organization of work in Fordism. Of course, not every product let alone every service can be mass-produced, but the assembly line became the model and orientation point for thinking about industrial production. It became, in other words, the 'production norm'. Other types of production organization came to be judged in terms of their distance from this 'ideal'. Mass production is associated with an increased use of unskilled workers, low educational requirements, and increasing power for management (engineers). Braverman (1974) offers a profound analysis of these tendencies, emphasizing the element of control by capital over labour in the organization of production. In his analysis Fordism (Taylorism) is not so much a transformation of 19 th century capitalism, but a continuation and intensification of it. His emphasis on the pure logic of capital leaves little room for the acknowledgement of discontinuities in the history of capitalism. Moreover, it makes it difficult to give adequate treatment to countercurrents and 'illogical' developments, that may contribute to future transformations of capitalist institutions. For example, in Braverman's analysis mass production stands for de-skilling. The fact that in all capitalist countries workers have spent much more time at school than a century ago is not accepted by Braverman as proof of increasing educational requirements. Even though his arguments shouldn't be dismissed too easily, his denial of up-skilling tendencies makes it difficult to recognize forces undermining the logic of Fordism. In fact, precisely in the years that Braverman wrote his book, unrest and protest in the factories were explained among other things by the rising educational level of workers and their aspirations for more interesting and more responsible work.

The determination of wages in Fordism is heavily influenced by the recognition of trade unions as legitimate representatives of the work force. In some countries collective bargaining has also extended to non-unionized workers because collective agreements are enforced by the state for the whole sector to which they pertain. Henry Ford can certainly not be considered as the originator of this aspect of Fordism. He resisted unionization of his work force with all possible means including violence. Nevertheless, mass production did create the preconditions for a new type of unionism that organized workers on an industrial basis instead of a specific trade or skill. Industrial unionism in turn allowed for a connection between wage rises and the rise of productivity at the branch or even national level. Specific skills and scarcities became less important in the determination of wages than the general development of the economy and the relative wage structure. 
With wages rising with productivity the 'consumption norm' of the working population also underwent important changes. We noted already the rise of 'social wages'. Besides that, Fordism has eliminated much of the specific 'proletarian' lifestyle that included the growing of vegetables on small plots of land and the noncommercial organization of 'recreation' by unions and other workers' organizations. In Fordism there is no differentiation anymore between consumption by the capitalists and consumption by the masses (differences of course remain). The pattern of worker consumption is no longer fundamentally different from that of shop-keepers, engineers, civil servants or managers. Mass consumption is consumption by the masses and the remaining differences are differences in size, style or quality, but not in economic substance.

The post-war changes in the institutional forms of the wage relation are being held responsible for the differences in economic development between the interbellum and the 'Age of Fordism'. Boyer and Coriat (1987) develop this point in a simple macro-economic model. They analyze the economy in terms of two relations between output growth and productivity growth. On the one hand they present productivity as a function of the growth of the market (i.e. of output in a closed economy), based on dynamic returns to scale and the effects of capital deepening due to accelerator-investment. On the other hand they produce a relation between demand and productivity, based among other things on a coupling between the rates of change of real wages and productivity. These are in fact simple expressions of the production norm and the consumption norm of Fordism. The latter relation is decisive: aggregate demand now becomes an increasing function of productivity, whereas the same function was decreasing in the inter-war period. Under specific conditions relating to the indexing of wages with respect to productivity, these two relations can generate a stable process of accumulation. "The model confirms that there may be a stable and fast growth path within this general accumulation regime with which mass production and consumption are associated. The rate of growth is higher [than in the inter-war period, BD], since demand is much more dynamic and spills over to productivity via increasing returns to scale, while capital deepening associated with the accelerator mechanism strengthens even more the productivity-growth relation. The pattern of development is stable if the indexing of wages to productivity is sufficient but not too high, so that it guarantees that any discrepancy between productive capacity and demand is self-correcting. (...) During the inter-war period, more productivity ultimately meant less employment. After the Second World War, within the new demand regime, the same movement simultaneously increases productivity, growth and possibly employment." (Boyer 1988b, p.621) Almost as an afterthought Boyer and Coriat point out that even though investment has been depicted as depending only on demand variations, profits obviously also play a role. An additional condition for stable Fordist growth is therefore formulated: the long run trend in distributive shares should not be adverse to profit. In fact, one may well wonder if that condition is sufficient if the capital-output ratio is rising (see below). The profit share, but also the profit rate, have to be maintained if capitalist social relations are to be reproduced. In the course of the $1970 \mathrm{~s}$ it became clear that the institutionalized relation between productivity growth and expansion of demand was conditioned by assumptions about the stability of profits. When profits were diminishing, market growth was 
Table 3.1

Annual rate of growth (\%) of GNP or GDP ( $\dot{Q}$ ) and GNP or GDP per worker ( $\dot{q})$

\begin{tabular}{|c|c|c|c|c|c|c|c|c|c|}
\hline & \multirow{2}{*}{$\begin{array}{c}\text { Earliest } \\
\text { year }\end{array}$} & \multicolumn{2}{|c|}{ Up to 1913} & \multicolumn{2}{|c|}{$1922^{1}-29^{b}$} & \multicolumn{2}{|c|}{$1929^{b}-37^{c}$} & \multicolumn{2}{|c|}{$1951-73$} \\
\hline & & $\dot{q}$ & $\dot{Q}$ & $\dot{q}$ & $\dot{Q}$ & $\dot{q}$ & $\dot{Q}$ & $\dot{q}$ & $\dot{Q}$ \\
\hline Japan & 1880 & 3.4 & 4.3 & 5.9 & 6.5 & 2.4 & 3.6 & $8.0^{d}$ & $9.5^{\circ}$ \\
\hline Sweden & 1863 & 2.4 & 3.1 & 3.3 & 3.9 & 1.9 & 2.3 & n.a. & n.a. \\
\hline United States & 1871 & 2.2 & 4.5 & 2.1 & 4.8 & 0.4 & 0.1 & 2.0 & 3.7 \\
\hline Canada & 1872 & 1.9 & 4.0 & 2.1 & 5.1 & -0.9 & -0.3 & 2.2 & 4.6 \\
\hline Denmark & 1872 & 2.1 & 3.2 & 2.1 & 3.6 & 1.1 & 2.0 & $3.3^{e}$ & $4.2^{f}$ \\
\hline Norway & 1865 & 1.3 & 2.1 & 3.1 & 3.9 & 2.0 & 2.5 & 3.9 & 4.2 \\
\hline France & 1855 & 1.5 & 1.6 & 5.8 & 5.8 & -1.3 & -2.1 & $4.8^{e}$ & 5.0 \\
\hline Germany & 1853 & 1.5 & 2.6 & 6.0 & 5.7 & 2.1 & 2.8 & 4.7 & 5.7 \\
\hline Italy & 1863 & 0.7 & 1.3 & 2.2 & 2.3 & 1.6 & 1.9 & 4.6 & 5.1 \\
\hline $\begin{array}{l}\text { United } \\
\text { kingdom }\end{array}$ & 1857 & 1.6 & 2.6 & 1.6 & 2.7 & 1.6 & 2.3 & 2.5 & 2.7 \\
\hline Netherlands & 1900 & 0.7 & 2.2 & 2.0 & 4.0 & 0.3 & 0.2 & 4.0 & 5.0 \\
\hline
\end{tabular}

' From 1925 for Germany and from 1923 for Sweden, b Or year of onset of depression if other than $1929,{ }^{c} 1938$ for Japan, ${ }^{d} 1953-73,{ }^{~} 1957-73,{ }^{A}$ 1954-73

Source: D.C. Paige, 'Economic Growth: The Last Hundred Years.' National Economic Review, July 1961; T. Cripps and R. Tarling, Growth in Advanced Capitalist Economies 1950-1970, Cambridge University Press, 1973; National Accounts of the OECD, 1962-1973, Vol. I and II, OECD, Paris; and Labour Force Statistics, 1962-1973, OECD, Paris. The figures used by Cripps and Tarling and the OECD are for GDP

Reproduced from Comwall 1977 p.11 
no longer a sufficient condition for investment and productivity growth. ${ }^{2}$

\subsection{The crisis of Fordism}

the economic breakdown of the 1970 s

It is generally agreed that the 1950 s and 1960 s were decades of unprecedented growth of income and productivity in the history of capitalism. Table 3.1 illustrates this point. It shows the spectacular recovery of growth rates between 1951 and 1973 after the dismal record of the 1930s. Beyond that, the table shows that the annual growth rates of many economies were more than double the rates they had experienced in the 19th century and up to the First World War. Not all countries shared equally in this process of expansion. The table makes clear that the performance of the United States and the United Kingdom did not differ significantly from past performance. In absolute terms, of course, the United States were way ahead of the other countries. This was the Age of Fordism. All other countries had the US as a point of orientation and as a competitor whose performance was to be imitated and if possible outdone.

It is also widely agreed that by the end of the 1960 s productivity was slowing down in several countries, that inflation was becoming a persistent problem, the international monetary system had become shaky and the terms of trade on several markets for raw materials (especially oil) were moving against the developed countries. And then came the oil crisis of 1973. At the outset this was no doubt a political crisis that cannot be explained by economic causes, but the rise in oil prices and the general fear of war brought out the already existing downward tendencies. Even though the oil crisis cannot be treated as the main cause of the following economic breakdown, it clearly became the turning point in postwar economic development. This is nicely illustrated by Figure 3.1. It shows trends in industrial production and employment for the (then nine) EEC countries between 1950 and 1978 . The year of the oil crisis represents the downturn, but a break of trends had already occurred in the second half of the 1960s.

A new and widely debated phenomenon of the 1970 s was the fact that these depressive tendencies in the economy were accompanied by high, often doubledigit levels of inflation. The phenomenon was named 'stagflation'. Theory thus far had predicted inflation only in situations of full employment. Now it seemed that keynesian aggregate demand policies to create employment would push the economy into unacceptable levels of inflation. Economists designed new theories

2 Muysken and Wagener (1986) have also taken the Verdoorn/Kaldor-relation between producticity growth and the growth of production/income as a starting point for an analysis of the slowdown of productivity growth in both capitalist and socialist economies in the 1970 s. They find that the slowdown of productivity growth in three capitalist countries can be largely explained by a slowdown in effective demand, whereas a similar slowdown in two socialist countries can be related to a slowdown in the supply of labour (and therefore of production). Their interpretation of these findings is that the economic systems in both cases are running into their inherent (institutionally defined) limitations. 


\section{Figure 3.1}

\section{Industrlal output and employment In the EEC nine}

$(1950-78): 1960=100$

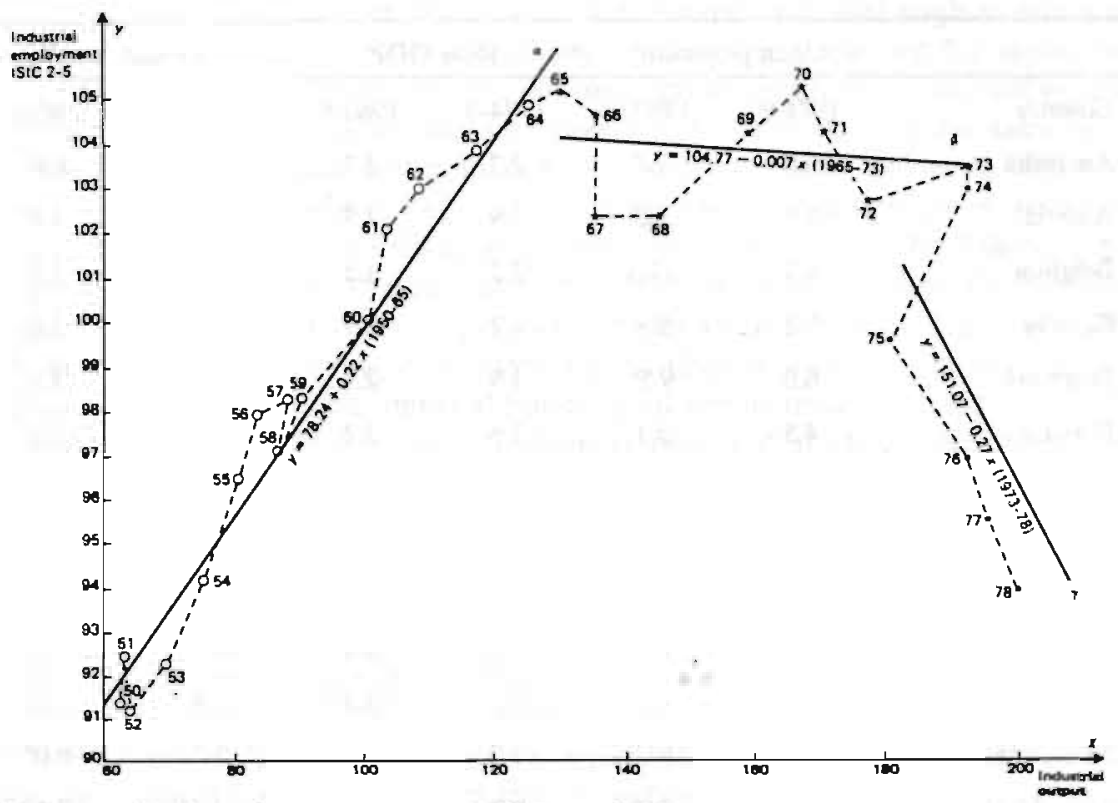

Source: Rothwell \& Zegveld (1981), p. 212

to deal with these developments. 'Vertical Phillips Curve analysis' (succinctly and critically reviewed in Cornwall 1990) and 'supply-side economics' provided the background for a shift in priorities and attitudes in economic policy-making. The fight against inflation received top priority. Inflation rates went down slowly but steadily in almost all OECD countries in the course of the 1980 s. Unemployment rates, however, remained high and indeed increased almost everywhere in the first half of the $1980 \mathrm{~s}$. Table 3.2 shows that for most countries between 1980 and 1986 growth of income and productivity were even lower than in the preceding six years.

The economic perfomance of the industrialized countries in the second half of the 1980s has clearly improved, with the growth rates of GNP rising again and unemployment falling, at least in some countries. Especially in Europe, however, unemployment is still at levels that are way above those of the $1950 \mathrm{~s}$ and ' $60 \mathrm{~s}$. This points to the continuing presence of imbalances that seem to be difficult to remove. The economic regularities of the Age of Fordism have disappeared. The 'Dream of Ever-Lasting Prosperity' (Lutz) is over. It has been followed by the nightmare of stagflation, persistent unemployment, oil crises and tensions in international economic relations. 
Table 3.2

Average unemployment rates, rates of growth of real gross domestic product, and the rates of growth of productivity in 18 OECD countries,1974-1979 and 1980-1986

\begin{tabular}{|c|c|c|c|c|c|c|}
\hline \multirow[b]{2}{*}{ Country } & \multicolumn{2}{|c|}{ Unemployment $^{2}$} & \multicolumn{2}{|c|}{ Real GDP } & \multicolumn{2}{|c|}{ Productivity $^{\mathrm{b}}$} \\
\hline & $1974-9$ & $1980-6$ & $1974-0$ & $1980-6$ & $1974-9$ & $1980-6$ \\
\hline Australia & 5.0 & 7.7 & 2.7 & 2.7 & 1.7 & $1.6^{\mathrm{c}}$ \\
\hline Austria & 1.8 & $3.2^{\mathrm{c}}$ & 2.9 & 1.7 & 2.5 & 1.8 \\
\hline Belgium & 6.3 & 11.3 & 2.2 & 1.5 & 2.3 & 1.9 \\
\hline Canada & 7.2 & 9.8 & 4.2 & 2.7 & 1.3 & 1.0 \\
\hline Denmark & 6.0 & $9.5^{c}$ & 1.9 & 22 & - & 1.9 \\
\hline Finland & 4.5 & 5.1 & 2.3 & 3.2 & 1.6 & 2.2 \\
\hline France & 4.5 & 8.6 & 3.0 & 1.1 & 2.7 & 1.8 \\
\hline Germany & 3.2 & 6.2 & 2.3 & 1.4 & 2.9 & 1.5 \\
\hline Ireland & 6.8 & $11.6^{\mathrm{c}}$ & 4.6 & 1.7 & 3.4 & 26 \\
\hline Italy & 6.6 & $9.2^{\mathrm{c}}$ & 2.6 & 2.1 & 1.7 & 1.7 \\
\hline Japan & 1.9 & 2.5 & 3.6 & 3.8 & 2.9 & 2.8 \\
\hline Netherlands & 5.0 & 10.0 & 2.7 & 1.1 & 2.2 & $0.0^{d}$ \\
\hline New Zealand & 0.9 & $4.3^{c}$ & 0.2 & 2.6 & -1.5 & $2.1^{c}$ \\
\hline Norway & 1.8 & 25 & 4.9 & 3.6 & 2.7 & $2.0^{\circ}$ \\
\hline Sweden & 1.9 & 2.8 & 1.8 & 1.7 & 0.5 & $0.8^{r}$ \\
\hline Switzerland & 0.4 & $0.6^{e}$ & -0.4 & 2.0 & 0.6 & 1.5 \\
\hline UK & 5.3 & 10.6 & 1.5 & 1.4 & 1.3 & 1.9 \\
\hline USA & 6.7 & 7.8 & 2.4 & 2.4 & 0.0 & 0.9 \\
\hline
\end{tabular}

- Standardized unemployment rates from the Revised OECD Data Set and Economic Outlook; ${ }^{\text {b }}$ Ratc of growth of real GDP per person employed; ${ }^{c} 1980-5 ;{ }^{d} 1980-2,1984-6 ;{ }^{\circ}$ $1981-6 ;{ }^{i} 1980-3,1985-6$

Sources: OECD, Historical Statistics, 1960-1986, OECD, Paris, 1988, tables 3.1 and 3.7; OECD, Economic Outlook, OECD, Paris, June 1987, tables R10 and R12; The Revised OECD Data Set, Centre for Labour Economics, London School of Economics

Reproduced from Cornwall 1990 p.43

The basic fact of a break in the post-war macro-economic patterns after 1973 is hardly being disputed. Not much in the way of consensus exists, however, concerning the explanation of this fact. Disagreement already starts with the use of the word 'crisis' to characterize the new situation. In mainstream economics, a breakdown of the economy can only be caused by non-economic, 'external factors' 
that prevent the economy from achieving a Pareto-optimal equilibrium. After the disturbance has run its course, the economy will return to equilibrium again (or in dynamic versions: to equilibrium growth). One of the first official analyses of the economic difficulties of the 1970 s, the so-called McCracken report (McCracken 1977), is often quoted as representative of this perspective. Although in fact it did present a quite thorough and rich analysis, it will be remembered for saying that "our reading of recent history is that the most important feature was an unusual bunching of unfortunate disturbances unlikely to be repeated on the same scale, the impact of which was compounded by some avoidable errors in economic policy." (McCracken 1977, p.14) Consequently, the report was quite optimistic about the possibility of the OECD economies to grow again in the following five to ten years at about the same rate as in the 1960s. As we know now, the ten years following the publication of this report were distinctly less dynamic than the $1960 \mathrm{~s}$. It is therefore not surprising that a growing number of analysts was arguing that more was going on than an 'unusual bunching of unfortunate circumstances'. The alternative to an explanation of this kind is one that tries to account for the economic difficulties by factors that are internal to the economy. If that is the case, the word 'crisis' can be used.

Classical economic theorizing sees crises as endogenous phenomena, to be explained by economic factors. The word 'crisis' is taken from the Greek, where it refers (among other things) to a decision or a judgement by a court. The point is, that after a crisis a new situation exists: an accused is either guilty or not guilty. Or in the medical sphere: after a crisis, a patient either dies or becomes healthy again. In classical economics a crisis sets the economy on a new track; it paves the way, not just for recovery, but also for renewal. Moreover, as in medicine, there is in classical theorizing also a notion of death, represented by various laws of falling profit rates, that would cause recurrent crises and eventually eliminate the capitalist class and therefore capitalism. Heterodox economists have often been interested in crisis-theories. Their critique of mainstream equilibrium economics led almost automatically to a preoccupation with problems of disequilibrium and breakdown. Karl Marx was one of the first economists who clearly recognized the cyclical patterns in the development of capitalism and elaborated various theoretical notions to explain them. Both Mitchell and Schumpeter produced voluminous studies under the title 'Business Cycles'. In the course of time, a distinction was made between the 'normal' (but in terms of general equilibrium analysis still inexplicable) ups and downs of capitalist economies (the so-called Juglar cycles) on the one hand and long-term movements in the development of capitalism on the other hand. The words 'depression' and 'crisis' came to be reserved for downward movements on the latter time-scale. If the word crisis is used for the period after 1973, two things are implied: first, that it is one of those longer periods of persistent downward tendencies in the history of capitalism; and second, that the causes for this development are to be found within the economic system itself.

By the time of the second oil crisis caused by the revolution in Iran (1979), books and articles proclaiming a crisis of various aspects of post-war capitalism were flooding the market. Many of these studies were written by non-economists: 
sociologists, political theorists and historians. Economists remained divided. A majority was still searching for various 'extemal' causes explaining what had now become recognized as a severe recession. The state was found to be the most important culprit. Denison's study 'Accounting for Slower Economic Growth' (1979) for instance was presented as a substantiation of "one of the major causes of retarded economic growth: the costs of government regulation of business" (cover text). A small but vocal minority of economists, however, was re-discovering crisis-theories and the heterodox economists that had been developing them. Especially Schumpeter and the theories of long waves to which he contributed were enjoying renewed popularity (see below). The elaboration of the régulation approach can be considered as part of this revival of heterodox thinking.

\section{the regulation approach and the crisis of Fordism}

In search of endogenous explanations of the crisis, the experiences of the $1950 \mathrm{~s}$ and '60's had to be reconsidered and re-evaluated as well. As we have seen, the régulation approach explains these experiences by the widespread introduction of institutional arrangements that allowed for intensive accumulation on the basis of mass consumption. Mass production techniques produced large productivity increases, which could be translated into (social) wage increases. Organized workers were prepared to accept the new organization of production if compensated by high and rising wages. High wages provided outlets for consumption goods, creating profits for producers of these goods, which in turn called for further investment (i.e. accumulation). This virtuous spiral of Fordist accumulation is further accomodated by several other institutional forms, like the large, vertically integrated enterprise, the welfare state, and the Bretton Woods system. The régulation approach thus encompasses several partial explanations offered by other theorists that emphasize such aspects as technological change, export-led growth, fiscal policies of the state, monopolist organization of the economy, etc..

The breakdown of this virtuous spiral must naturally be related to the same institutional forms that were advanced in its explanation. In fact, two general arguments are possible. Either the institutional forms are breaking down because of internal developmental dynamics, leading for instance to lack of coherence and consistency in the mode of regulation, or economic development (accumulation) under the regime of Fordism has led to new conflicts and economic imbalances that cannot be accomodated by the existing institutional forms. Different authors emphasize and investigate the crisis in terms of different institutional forms. Boyer (1988) has grouped the various explanations under three headings: 1. Diminishing effects on productivity of the Fordist organization of mass production; 2. Destabilizing effects of internationalization of competition on monopolist pricing policies (and therefore on the mechanisms governing wage formation); more generally, destabilizing effects because of the disappearance of complementary relations between national economies; 3 . Destabilizing effects of some rigidities in the Fordist institutions of wage formation. The first group of explanations is concerned with the immanent limits of the Fordist paradigm of production organization and production technology (the production norm). In this type of 
analysis the crisis could eventually be seen as a crisis of the regime of accumulation (but as such the crisis is always affecting the prevailing institutional forms of the economy). The other two groups of explanations are dealing with newly arising problems, caused by the very success of Fordism, that Fordist institutions find difficult to handle. These are clearly pointing to a crisis of the mode of regulation.

1. Central to many crisis-explanations is the 'mystery' (Denison) of the slowdown of productivity growth in several Western countries and especially the United States since the end of the 1960 s. The reasons for this slowdown as seen by the régulation theorists can be either 'technical' or 'social'. A technical explanation points to diminishing returns on the application of Fordist principles. Beyond a certain plant size, returns to scale tend to disappear. Similarly, mechanization also shows diminishing returns. The organizational principles of Taylorism are very effective, but beyond a certain point, a further division of labour and a stricter separation between conception and execution of work make no sense and indeed become counter-productive. In the course of time, the Fordist system had led to a slow but steady increase in the share of indirect workers in the total work force. Fordist factories were becoming bureaucratic machines. As we will see, the Japanese found out that productivity could actually be increased by re-integrating production work and quality control. A social explanation of the productivity slowdown points to increasing worker resistance to the Fordist production system. Labour turnover, absenteeism, sabotage and strikes can be seen as signals of dissatisfaction. While it seemed possible to buy off these complaints by rising wages in the early stages of Fordism, by the end of the 1960 s new demands concerning the quality of work were being voiced in many countries. A new, better educated generation of workers was entering the factories, with attitudes and expectations that were distinctly different from those of the generation that had entered the Age of Fordism with memories of depression and war. Within the logic of Fordism, higher wages were the only answer to worker resistance (beginning already with the five-dollar-day). If productivity was slowing down at the same time for technical reasons, profits would be squeezed from both sides.

2. In Fordism, wages are an elements of production costs, but they also are an important component of demand. Internationalization of competition and production led to increasing tensions between these two aspects of wages, because the wage rate came to function also as a determinant of international competitiveness. "In the ' $70 \mathrm{~s}$, the trade-off between growth of inner market and clearing of trade balances became more and more uneasy. With the monetarist shock [the choice in favour of anti-inflation policies around 1980, BD], some of the greatest advanced capitalist countries made their choice. Giving priority to competitivity and reconstruction of profits, they undertook the destruction of the whole set of wage regulations and agreements, thus putting a definitive end to the Fordist era." (Leborgne/Lipietz 1987, p.8) In the Fordist mode of regulation, intercapitalist relations (market structures) were generally characterized as being monopolistic or oligopolistic. Because of that, mark-up pricing was seen as a logical and empirically valid element in the process of wage formation. Internationalization, however, re-introduced the forces of competition in these oligopolistic structures. Given that exchange rates cannot be used (at least not 
exclusively) to balance out differences in wage increases between countries, internationalization presented new restraints on the process of wage formation.

Internationalization was both an expression of and a further contribution to the narrowing of the economic distances between the various developed economies. In the late 1960 s there was a lot of debate about the technological gap between the United States and Europe. The American economic machine was presented as a formidable challenge ('le defi americain'). Maybe that debate was only possible, because the gap had become so narrow that firms and industries could measure it and consider the jump. In any case, only a few years later, the breakdown of the Bretton Woods system was widely analyzed as the end of American hegemony in international capitalism. As capitalist countries were beginning to perform at comparable levels, competition between them became more intense. Although the strong growth of international trade in the post-war period had to a large extent been intra-industry trade, it had largely been trade in complementary goods (of different technological levels), that were not competing directly with each other. After 1973, the focus is increasingly shifting towards competition in advanced technology markets (Roobeek 1988). At the same time, national economies are beginning to move synchronously. Whereas minor dips in an economy during the fifties and sixties could be evened out by exports to other economies that were moving up at the time, such export-led compensation was no longer possible, after all economies began to follow similar cyclical patterns. All this, of course, also meant a considerable limitation on the possibilities of governments to deploy fiscal, monetary or exchange-rate policies to manage aggregate demand levels in their national economies.

3. With productivity growth slowing down and internationalization introducing new constraints in economic decision making, the Fordist institutions regulating the wage relation came under pressure. Capital intensity was rising faster than productivity and therefore the capital output ratio was rising as well. Under such circumstances, the rate of profit can only be maintained, if the share of wages in national income falls. Fordist institutions were based on wages rising with productivity and the share of wages remaining stable. What happened in fact is that Fordist institutions caused the wage share to rise during the '70s (Mazier 1982). Moreover, "a quasi-perfect indexation of nominal wages to consumer prices, jointly with oligopolistic pricing, generated a wage-price-profit spiral, which culminated after the two oil shocks in two-digit inflation. Hence pressures to reverse previously accomodating monetary policies increased in reverse proportion to the strength of each nation's productive system." (Boyer 1988a, p.88) The last remark points to the popularity of incisive anti-inflation policies in the United Kingdom (and the United States) in the first half of the 1980s. It is not without interest that an early analysis of the crisis (written indeed before 1973) in terms of profits being 'squeezed' between workers' demands and international competition was based on the case of Britain. Glyn and Sutcliffe (1974, first published in English in 1972) argued that the profit squeeze was a logical outcome of the way post-war capitalism and especially its industrial relations had been organized. The squeeze was not necessarily wanted by any of the actors concerned (unions, capitalists or the state). What was needed now in their opinion was to uncover 
these logical connections. Workers had to be made conscious of their chances; they should keep on 'squeezing' until capitalism would collapse. Otherwise, so Glyn and Sutcliffe, times of defeat and darkness for the labour movement would be inevitable. No doubt, they have seen their worst expectations confirmed by the era Thatcher. From a theoretical point of view, however, one wonders if the capitalist order had no other alternatives to offer than workers squeezing capitalists to death or the other way around. It is no doubt one of the merits of the régulation approach that it introduced into the crisis debate a notion of continuity through institutional change. The implication is that workers and their organizations could also play a constructive role in the construction of new institutional forms.

The economic crisis is thus analyzed as a crisis of the institutional forms of Fordism. The economic actors play the game according to the rules, but the result is no longer satisfactory to one or more of the parties concerned. As a result, efforts will be undertaken to change the rules. Depending on the crisis-explanation one can think of new production concepts (a new production norm); protectionist measures against suppliers from low-wage countries and other forms of 'unfair' competition; and adaptations in the industrial relations system. Wherever one starts, however, institutional change in one set of relations will cause further changes in other institutional forms. The different institutional forms have developed together and hang together as a complete system of rules. It is unlikely that only one institutional form could change, while the others remained stable. It is one of the reasons why a crisis of the mode of regulation, contrary to the 'reproductive' crises of the regular business cycle, takes up so much time. New institutional forms have to be developed, negotiated out and balanced against each other in complex political processes. From the régulation perspective, the period after 1973 therefore has to be analyzed as a period of search. While there may have been some efforts at repair of the Fordist institutions in the beginning, more radical departures from the post-war order were soon advocated from various quarters. In the final part of this chapter we will take a look at the process of search for post-Fordist institutions as it is reflected in various visions of the future that can be found in social science literature. Before we do so, however, it will be useful to look at a few other contributions to the debate about the crisis of Fordism.

\subsection{Others about the crisis of Fordism}

The régulation approach has of course not been the only school in political economy to offer an explanation for the post-war growth-regime and its breakdown after 1973 . Various other, partly overlapping and partly complementary approaches exist that deserve to be mentioned here. We start with the theory of long waves in the development of capitalism, that is connected with the names of Kondratieff and Schumpeter. We will then turn to the analysis of the crisis by a group of American radical economists whose ideas have developed parallel to (and sometimes in interaction with) the régulation approach. Finally, we will briefly review the analysis in terms of 'social rigidities' as developed by Olson. 
A good start for a brief review of the 'long waves' explanation of the crisis of Fordism is the early contribution by Mensch (Mensch 1977, first published in 1975). Mensch basically argued that the history of capitalism was characterized by long waves of development that were caused by the bunching in time of basic innovations. Basic innovations are product or process innovations that give rise to new industries and new occupations. They are the source of bifurcations in economic history. Basic innovations are followed by a series of improvementinnovations that will in the long run be subject to diminishing returns. According to Mensch there is no technical necessity for the bunching of basic innovations, because the supply of useful inventions is practically continuous over time. The bunching is caused by the fact that capitalists tend to avoid the risks involved with the introduction of radical innovations and instead prefer to look for gradual improvements of prevailing techniques. They continue to do so even after the potential of these techniques has by and large run out. What follows is a situation of 'technological stalemate' in which only 'pseudo-innovations' without economic impact are introduced. The economy is slowing down and eventually runs into fullscale depression. Only then, battered by the destructive effects of the crisis, will capitalists finally find the way to new basic innovations that will carry the upswing of the next long wave. Mensch saw the economic problems of the late ' 60 s and early ' 70 s as clear signals of a new technological stalemate. He argued that sensible state policies would be able to prevent the coming of a deep depression and help potential entrepreneurs to introduce new technologies. State policies moreover might be able to encourage a more selective treatment of the supply of basic inventions, so that the social and environmental costs that had been associated with earlier expansion phases of capitalism could be avoided. His plea for active technology policies, although perhaps overly optimistic concerning the possibilities of state policy, was certainly influential throughout the 1970s, as policy in most OECD countries and especially in Europe was shifting from defensive restructuring policies to offensive technology and innovation policies.

Mensch's work formed the beginning of a revival of long-wave theorizing. Earlier contributions had been made by the Russian economist Kondratieff in the 1920s and by Schumpeter in the $1930 \mathrm{~s}^{3}{ }^{3}$ The theory has always generated controversy. Sceptics point out that even the existence of wave-like movements in long-term economic development is difficult to prove, because of severe measurement problems. Even more controversial, however, is the position that this long-term wave-like movement is indeed a cyclical movement which is generated by the workings of the economy. Mensch followed Schumpeter in relating the long wave to the bunching of innovations in time. Already in Schumpeter's early work (1980, first published in German in 1911) innovation is the characteristic contribution of the entrepreneur to economic development; it is the final cause of all profits and therefore the essence of capitalist development. It is only logical that Schumpeter also linked the long-term movements of capitalist economies to innovations. In

${ }^{3}$ Brief histories of long-wave theorizing can be found in Van Duijn (1979) and Kleinknecht (1987). 
order to do so he had to hypothesize a clustering of innovations in time. He was criticized (among others by Kuznets) for providing no proof of the clustering of inovations. Mensch did provide some empirical evidence, which he considered as proof of the bunching of (basic) innovations in the trough of a long wave depression. An extensive debate developed subsequently around this particular point. Both the empirical finding of bunching was questioned and the logic of it taking place in the depth of the depression. Why, it was asked, would entrepreneurs take the immense risks associated with basic innovations in the depth of the depression, when prospects of profitability are poor? Van Duijn (1979), who was basically supportive of Mensch, introduced a Forrester-inspired multiplier accelerator mechanism for the investment goods industry to explain the lower turning point of the long wave. He saw bunching of basic innovations taking place in the early phases of expansion, after the upturn has restored confidence. Kleinknecht supplied new evidence for the bunching thesis, but concluded that Mensch's view of clusters of basic innovations in the trough of the long wave was untenable. "In fact, we should no longer speak of clusters but rather of long waves of radical innovations, covering not only the troughs but also the recovery and early upswing phases of the long waves." (Kleinknecht 1987, p.203) Freeman et al. (1982) argued that basic innovations are spread much more evenly through time than suggested by Mensch or Kleinknecht. Moreover, they emphasized that the diffusion process is more important economically than the first introduction (innovation) of a new technique. The recovery and expansion of a Kondratieff wave would have to be associated with the diffusion of basic innovations rather than with their first introduction. In the further elaboration of this argument Freeman et al. clearly moved beyond Mensch's approach. What was important was not the unlikely bunching of disparate innovations, they asserted, but the appearance of 'new technology systems' or 'constellations' of innovations that were technically, economically and socially related. The long-wave upswing was not to be explained by a synchronization of innovations (where it is anyhow very difficult to pinpoint an innovation in time), but by the gradual rise of a mutually dependent and mutually stimulating set of innovations, some of them new, but others older. Although these authors were following Schumpeter in his emphasis on the importance of technological change for the development of capitalism, they were wary of the tendency towards technological determinism that comes easy with this approach. The concept of 'new technology systems' served to introduce additiona] economic and social elements into the analysis: "what matters from the standpoint of large-scale economic fluctuations is not so much the date of a particular basic innovation as a constellation of circumstances favourable to the exceptionally rapid growth of one or more new industries, each involving the combination of a number of related inventions, innovations and economic and social changes. We would now insist furthermore on the vital importance of Schumpeter's point about manageria] and organizational innovations. These may often be just as important as the technical changes for the growth of an industry or technology. (...) The capacity for social innovation is very variable and in addition to the capacity to generate and launch a particular group of technical innovations this must surely be one of the main reasons for the changing locus of technological leadership in the various long waves" (Freeman et al. 1982, p.70/1) 
Freeman et al. point out that the various innovations of a new technology system do not spread evenly across sectors. The result is differential productivity growth and structural change in the economy. Industries unaffected by the new technologies may be expected to decline in relative importance and eventually decline also in absolute terms. The resulting loss of employment can be compensated by the growth of the new industries associated with the new technologies. Depressions are then identified as "periods in which the industrial structure is fundamentally unbalanced by an increasing number of industrial sectors entering their declining phase, and a decreasing number of expanding industries." (Freeman et al. 1982, p.134) In their analysis of the post-war Kondratieff upswing, Freeman et al. emphasize the rise of the 'technology systems' of synthetic materials (drugs and plastics) and electronics (television, transistors and computers) in that period. They show that the employment generation of both industries fell substantially in the course of the post-war period, especially in the 1970s. Moreover, the structure of these main 'carrier' industries (as well as overall industrial structure) became more concentrated over time, which led to different pricing behaviour. Instead of distributing productivity gains to all consumers in the form of lower prices, firms became more inclined to pay higher wages to their employees. The result of these and other structural changes following the maturing of the post-war technology systems was a weakening of the relationship between employment, output and productivity growth, leading to breakdown or at least to what Pasinetti called a 'pause' in economic development.

In this admittedly very brief presentation of a Schumpeterian, long-wave explanation of the post-war rise and decline of Fordism we have emphasized the points where this approach clearly differs from the régulation approach. Two differences stand out in particular. The first one is the notion of wave-like movements in economic development. The régulation approach distinguishes different phases in the development of capitalism, and although these phases have a resemblance with the long waves, they are not the same. Specifically, the régulation theory offers no mechanisms that guarantee a new upturn, comparable to the bunching of innovations offered by Mensch. It should be noted that this quasi-automatic recovery mechanism (and the emphasis on wave-like movements) is less prominent in the contributions by Freeman et al.. The second difference is the emphasis on technological change. The long-wave literature on the crisis of the 1970s makes clear that the régulation approach, because of its emphasis on the wage relation and the production norms of Fordism (mass production) has tended to neglect aspects of technological change that are not related to the organization of the production process. The importance of mass production for post-war economic development is undeniable (indeed also in the electronics industry), but the additional impetus provided by the new carrier industries is equally undeniable. The macro-economic orientation of the régulation approach has prevented it from taking a clear view of technology-related processes of structural economic change that are going on during the rise and fall of modes of regulation and regimes of accumulation. In that sense, the Schumpeterian long-wave approach could fill an important gap in régulation theory. This would, among other things, require an analysis of the relations and interactions between the rise of new technology systems and the construction of new modes of regulation. Some very first steps 
Toblo 3.3

The Fourth Kondratiov

\begin{tabular}{|c|c|c|c|c|c|c|c|c|c|c|c|}
\hline 1 & 2 & & 3 & 4 & & 5 & 6 & & 7 & & 8 \\
\hline $\begin{array}{l}\text { Approx. } \\
\text { periodisation } \\
\text { Upswing } \\
\text { Downswing }\end{array}$ & Description & \multicolumn{2}{|c|}{$\begin{array}{l}\text { Main 'carrier } \\
\text { branches' and } \\
\text { induced growth } \\
\text { sectors infra. } \\
\text { stucture }\end{array}$} & \multicolumn{2}{|c|}{$\begin{array}{l}\text { Key lactor indes- } \\
\text { tries offering } \\
\text { abundant supply } \\
\text { at descending } \\
\text { price }\end{array}$} & $\begin{array}{l}\text { Other sectors } \\
\text { growing rapidly } \\
\text { from small base }\end{array}$ & $\begin{array}{l}\text { Limilations of } \\
\text { previous techno- } \\
\text { economic para- } \\
\text { digm and ways } \\
\text { in which naw } \\
\text { paradigm otters } \\
\text { some solutions }\end{array}$ & \multicolumn{2}{|c|}{$\begin{array}{l}\text { Organisation of } \\
\text { firms and forms } \\
\text { of cooperation } \\
\text { and compotition }\end{array}$} & \multicolumn{2}{|c|}{$\begin{array}{l}\text { Technological } \\
\text { leaders }\end{array}$} \\
\hline $\begin{array}{l}1930 \text { \& } 1940 \text { s } \\
\text { to } 1980 \text { s \& } \\
1990 \text { s } \\
\text { Golden age of } \\
\text { growth and } \\
\text { Koynesian ful } \\
\text { employment } \\
\text { Crisis ol struc- } \\
\text { tural adjustment }\end{array}$ & $\begin{array}{l}\text { Fordist mass } \\
\text { production } \\
\text { Kondratioff }\end{array}$ & \multicolumn{2}{|c|}{$\begin{array}{l}\text { Automobiles } \\
\text { Trucks } \\
\text { Tractors } \\
\text { Tanks } \\
\text { Ammaments } \\
\text { for molorised } \\
\text { wartare } \\
\text { Aircath } \\
\text { Consumer } \\
\text { durables } \\
\text { Process plant } \\
\text { Synthetic } \\
\text { materials } \\
\text { Petro-chernicals }\end{array}$} & $\begin{array}{l}\text { Energy } \\
\text { (especially }\end{array}$ & ㅇii) & $\begin{array}{l}\text { Computers } \\
\text { Radar } \\
\text { NC machine } \\
\text { tools } \\
\text { Drugs } \\
\text { Nuclear } \\
\text { weapons } \\
\text { and power } \\
\text { Missiles } \\
\text { Micro- electro- } \\
\text { nics } \\
\text { Software }\end{array}$ & $\begin{array}{l}\text { Limitations of } \\
\text { scale of batch } \\
\text { production over- } \\
\text { come by flow } \\
\text { processes and } \\
\text { assembly-line } \\
\text { production tech- } \\
\text { niques, full } \\
\text { standardisation } \\
\text { of components } \\
\text { and materials } \\
\text { and abundant } \\
\text { cheap energy. } \\
\text { New patterns of } \\
\text { industrial location } \\
\text { and urban } \\
\text { development } \\
\text { through speed } \\
\text { and flexibility of } \\
\text { automobile and } \\
\text { air transport. } \\
\text { Further cheape- } \\
\text { ning of mass } \\
\text { consumption } \\
\text { products }\end{array}$ & $\begin{array}{l}\text { Origo } \\
\text { comy } \\
\text { Muthi } \\
\text { porat } \\
\text { on di } \\
\text { inves } \\
\text { multi- } \\
\text { ions. } \\
\text { Com } \\
\text { contr } \\
\text { 'arms } \\
\text { basis } \\
\text { Integ } \\
\text { creas } \\
\text { entra } \\
\text { nalis: } \\
\text { hiera } \\
\text { rol. } \\
\text { 'Tech } \\
\text { ture' } \\
\text { corpo }\end{array}$ & $\begin{array}{l}\text { olistic } \\
\text { ttifion. } \\
\text { ational cor- } \\
\text { ons based } \\
\text { oct foreign } \\
\text { nent and } \\
\text { vant locat- } \\
\text { etilive sub- } \\
\text { cting on } \\
\text { length' } \\
\text { or vertical } \\
\text { ation. In- } \\
\text { ng conc- } \\
\text { on, divisio- } \\
\text { lion and } \\
\text { thical cont- } \\
\text { lo-struc- } \\
\text { i large } \\
\text { ations }\end{array}$ & $\begin{array}{l}\text { USA } \\
\text { Germ } \\
\text { Other } \\
\text { Japar } \\
\text { Swed } \\
\text { Switz } \\
\text { USSF } \\
\text { Other } \\
\text { Cana } \\
\text { Ausir }\end{array}$ & $\begin{array}{l}\text { Iany } \\
\text { EEC } \\
\text { entand } \\
\text { EFTA } \\
\text { alia }\end{array}$ \\
\hline 9 & & & & & & 12 & 13 & & 14 & & 15 \\
\hline $\begin{array}{l}\text { Other industrial } \\
\text { and newly } \\
\text { industrialising } \\
\text { countries }\end{array}$ & \multicolumn{2}{|c|}{$\begin{array}{l}\text { Some leatures of } \\
\text { national regimes } \\
\text { of regulation }\end{array}$} & \multicolumn{2}{|c|}{$\begin{array}{l}\text { Aspects of the } \\
\text { international } \\
\text { regulatory } \\
\text { regime }\end{array}$} & \multicolumn{2}{|c|}{$\begin{array}{l}\text { Main leatures of the } \\
\text { national systern of } \\
\text { innovation }\end{array}$} & \multicolumn{2}{|c|}{$\begin{array}{l}\text { Some leabures of } \\
\text { tertiary sector } \\
\text { development }\end{array}$} & \multicolumn{2}{|c|}{$\begin{array}{l}\text { Representabive } \\
\text { innovative } \\
\text { entrepreneurs } \\
\text { engineers }\end{array}$} & $\begin{array}{l}\text { Political } \\
\text { economists } \\
\text { and } \\
\text { philosophers }\end{array}$ \\
\hline $\begin{array}{l}\text { Other } \\
\text { Eastern European } \\
\text { Korea } \\
\text { Brazil } \\
\text { Mexico } \\
\text { Venezuela } \\
\text { Argentina } \\
\text { China } \\
\text { India } \\
\text { Taiwan }\end{array}$ & \multicolumn{2}{|c|}{$\begin{array}{l}\text { 'Wellare state' and } \\
\text { 'warlare state'. } \\
\text { Atlempted state } \\
\text { regulation of } \\
\text { investment, growth } \\
\text { and employment } \\
\text { by Keynesian } \\
\text { techriques. High } \\
\text { levels of state } \\
\text { expenditure and } \\
\text { involvement. } \\
\text { 'Social } \\
\text { partnership' with } \\
\text { unions after } \\
\text { collapse of lasc- } \\
\text { ism. } \\
\text { "Roll-back' of } \\
\text { wellare state } \\
\text { deregulation and } \\
\text { privatisation during } \\
\text { crisis of } \\
\text { adjustrnent }\end{array}$} & \multicolumn{2}{|c|}{$\begin{array}{l}\text { 'Pax Americana' } \\
\text { US sconomic and } \\
\text { miltary } \\
\text { dominance. } \\
\text { Decolonisation. } \\
\text { Arms race and } \\
\text { cold war with } \\
\text { USSR. US- } \\
\text { dominaled intema- } \\
\text { tonal financial and } \\
\text { trade regime } \\
\text { (GATT, IMF, } \\
\text { World Bark) } \\
\text { Destabifsation of } \\
\text { Bretton Woods } \\
\text { regime in 1970s }\end{array}$} & \multicolumn{2}{|c|}{$\begin{array}{l}\text { Spread of specialised } A \\
\text { and D departments lo } \\
\text { most industries. Large- } \\
\text { scale state involvement } \\
\text { in military } R \text { and D } \\
\text { through contracts and } \\
\text { national laboratories. } \\
\text { Increasing state involve- } \\
\text { ment in civil science and } \\
\text { technology. Rapid } \\
\text { expansion of secondary } \\
\text { and higher education } \\
\text { and of industrial iraining. } \\
\text { Transter of lechnology } \\
\text { through extensive } \\
\text { licensing and know-how } \\
\text { agreements and } \\
\text { investment by multi- } \\
\text { national corporations. } \\
\text { Learning by doing using } \\
\text { and interacting. }\end{array}$} & \multicolumn{2}{|c|}{$\begin{array}{l}\text { Sharp decline of } \\
\text { domestic service. } \\
\text { Sell-service fast } \\
\text { food and growth of } \\
\text { super-markets and } \\
\text { hypermarkets, } \\
\text { petrol service } \\
\text { stations. Continued } \\
\text { growth of state } \\
\text { bureaucracy, armed } \\
\text { forces and sodial } \\
\text { services. Rapid } \\
\text { growth ol research } \\
\text { and professions } \\
\text { and financial } \\
\text { services, packaged } \\
\text { tourism and air } \\
\text { travel on very large } \\
\text { scale. }\end{array}$} & $\begin{array}{l}\text { Sloan } \\
\text { MeNamara } \\
\text { Ford } \\
\text { Agneli } \\
\text { Nordhoff } \\
\text { Matsushila }\end{array}$ & & $\begin{array}{l}\text { Keynes } \\
\text { Schumpeler } \\
\text { Kalocks }\end{array}$ \\
\hline
\end{tabular}

Source: Technical Change and Economic Theory (1988) odtod by Dosi et al. (1988), 0.50-57 
have recently been done in that direction (Boyer 1988a; Freeman \& Perez 1988). Table 3.3 shows the elements that enter into a combination of Schumpeterian and institutional analysis of the 'Fourth Kondratieff', i.e. the cycle of Fordism.

\section{social structure of accumulation}

In the United States, radical economists developed a framework for analysis of the crisis of Fordism, that is clearly inspired by both the long wave theory and the régulation approach, but has some distinctive features that warrant separate treatment. In a critique of the idea that long waves are generated automatically by the workings of the economy, David Gordon introduced the concept of a 'socia] structure of accumulation' (SSA). Every period of rapid accumulation in the history of capitalism is grounded in the existence of a set of critical socioeconomic institutions. These institutions, however, are historically contingent: there is no automatism that guarantees the rise of such institutions favorable to accumulation. In other words: a specific social structure of accumulation may run out of steam, but there is no mechanism to generate a new structure. In this respect, the SSAapproach is similar to the regulation approach. The main difference is in the analysis of the dynamics of the social structure itself. Whereas the régulation approach tends to emphasize the economic functionality or disfunctionality of social institutions and arrangements, the SSA-approach emphasizes their political functions and explains the development of a structure of accumulation by changes in the relative power of the capitalist class vis-à-vis the workers. Consequently, the SSA-approach sees a crisis as an expression of rising resistance and power on the part of the working class, whereas the régulation approach is inclined to look for unintended, macro-economic bottlenecks and imbalances that slow down the accumulation process and may or may not be the result of actions by workers.

A first synthesis of work on the SSA-approach was presented in 1982 by Gordon, Edwards and Reich in their study of the historical transformation of labor in the United States: 'Segmented Work, Divided Workers'. It combines Gordon's work on long waves with Edwards' studies of the labour process in the tradition of Braverman (Edwards 1979). In a bold and sweeping analysis the authors present an overview of capitalist development in the United States since the 1820 s. They distinguish three long swings, which are characterized by different social structures of accumulation. Their analysis focuses on the institutions of the labour market and the structure of the work force. Thus, the period from the $1820 \mathrm{~s}$ to the $1890 \mathrm{~s}$ is one of 'initial proletarianization'. The period from the 1870 s to World War II is the period of 'homogenization'. The authors argue that the period of rapid accumulation after the Second World War was conditioned by a social structure characterized by 'segmentation' of the work force. This segmentation was caused by the creation of internal labour markets and by the integration of industria] unions into collective bargaining structures. These were the main mechanisms used by the large corporations to confront the threat posed by the homogenization of the work force and industrial unionism. Segmentation divided up the working class into different fractions with different interests and different levels of organization. It resulted also in a relative decline of the direct production workers in large enterprises (the 'subordinate primary segment') and a growing relative importance 
of less unionized indirect and professional workers (the 'independent primary segment'), and of workers in secondary jobs in smaller firms and traditional, nonunion areas of the economy. Segmentation guaranteed capitalist control in the 1950 s and '60s. It is presented as a crucial element of a complex of laws, institutions and arrangements that the authors call 'the postwar accord': "This social structure of accumulation was rooted in the Wagner Act, Social Security, Taft-Hartley, the Employment Act of 1946, and the Bretton Woods system and encompassed segmented labor markets, diverse (simple, technical, and bureaucratic) systems of control of the labor process, class conflict channeled into the governmental arena, an extensive economic role for government, and the maintenance of a hegemonic military posture to protect the opportunity for American corporations to invest abroad." (Gordon et al. 1982, p.240)

The analysis is obviously inspired by the régulation approach, but puts more emphasis on class struggle, which is given a primary role in the explanation of long swings. Several critics of the book point out that the role and importance of competition between capitals is under-emphasized (Nolan \& Edwards 1984; Wilkinson 1984). In fact, increasing competition between capitals is seen more as a sign of diminishing power of the capitalist class than as a separate regulatory mechanism in the social organization of capitalism. Consequently, the creative aspects of competition, also in terms of social innovation, i.e. as part of the process of search for new institutional forms, tend to be underestimated in the SSA approach and the potential and need for political forms of social innovation (bargaining, legislation) correspondingly overestimated.

Gordon et al. argue that the postwar accord came under increasing pressure from the workers in the course of the 1960s. There was an increase in absenteeism and a decline in workers' willingness to accept Fordist discipline. Moreover, even though official strike activities went down in the 1970s (because of rising unemployment), worker discontent remained visible in wildcat strikes, demands concerning working conditions, opposition to traditional union leadership and the like. Basically then, the crisis of Fordism seems to flow from increasing resistance on the part of the workers. This part of the analysis has been further developed by Bowles, Gordon and Weisskopf in their programmatic study of the crisis: 'Beyond the Waste Land' (1984; also Weisskopf et al. 1983). In an econometric analysis of the slowdown of aggregate productivity growth, Weisskopf et al. present a 'social model of aggregate productivity growth', which includes both a 'Schumpeter effect' and a 'Marx effect'. The Schumpeter effect introduces the possibility that the rate of technical change varies with competitive conditions in the economy. The Marx effect, which is at the core of the analysis, allows for a differentiation between hours of labor hired and effective labor hours, the difference being an expression of the intensity of work. The latter is not constant but changing over time, depending on employer control over employees and on workers' motivation. After inventive and sometimes adventurous operationalization of these variables, the authors present estimations of their model. They show that by the inclusion of social variables a much larger part of the decline of productivity growth can be explained than in more traditional analysis in which variations in technological progress and the capital-labour ratio are the only explanatory 
variables. Because of the difficulty of finding good indicators for some of their social variables the results are open to different interpretations, but they do suggest that conventional studies of the productivity slowdown have been underspecified and therefore overestimated the impact of changes in the rate of growth of the capital-labor ratio. The policy implication is clear: increasing investment will be less effective than expected in reviving productivity growth.

The analysis of the crisis of Fordism presented by the SSA-approach is a predominantly political analysis. Although it is recognized that a variety of factors account for the continuous slowdown in economic growth since the mid 1960s, the crisis is caused by the inability of the political system to deal with this problem. "The deterioration of social relations after 1966 led to escalating conflict over the division of a more and more slowly growing pie. The relations of domination and subordination built into the postwar system amplified these conflicts. (...) In the contentious U.S. political and economic climate of the 1970 s, there was no possibility of a cooperative accomodation among rival claimants, no prospect of an agreement to share in the austerity implied by the slowdown in hourly income growth. Nor could the inflationary conflict be resolved by a quick and decisive victory for capital - as hard as the corporations tried." (Bowles et al. 1984, p.117/8) The authors describe the 1970 s as the era of the Great Repression, which did not succeed in restoring the power of business. It was followed after 1979 by much more aggressive 'blitzkrieg attacks' by business forces. Bowles et al. emphasize that maintenance of corporate power, which is necessary for further accumulation of capital, requires increasingly elaborate measures to control and repress workers. "(T)he high and rising costs of corporate power explain the slowdown of productivity growth in the U.S. economy since the mid-1960s." The costs of repression, they argue, represent an enormous social waste, that could be eliminated by the creation of a truly 'democratic economy'. The rate of growth of productivity could for instance be restored by raising work intensity on the basis of increasing worker motivation through participatory and democratic organization of the workplace and rapid wage growth.

In a later analysis of the Reagan years Bowles et al. (1989) differentiate between 'underlying capitalist power', which is basically determined by the institutional structure of the economy, and 'measured capitalist power', for which they use indicators of e.g. worker resistance, trade power, capital's tax share, and import penetration. They argue that the business offensive under Reagan has succeeded in increasing measured capitalist power. The underlying power of capital, however, did not increase. The underlying structural relationships of the U.S. economy did not change in a manner favorable to rapid accumulation. Low levels of capacity utilization and high real interest rates helped capital to strike favorable deals with workers, citizens in general and indeed with the rest of the world, but at the price of dampening investment and profitability. The 'conservative' supply-side econnmics of the first half of the 1980 s, so Bowles et al., cannot be considered as a constructive contribution to the search for a new social structure of accumulation, but rather as a short-sighted program of redistribution of wealth and income by means of changes in tax and social policies. 
The American SSA-approach differs from the régulation approach mainly in its focus on class struggle. In fact, the régulation approach is so diverse, that some French authors may see little difference between their approach and those of the American radicals. Weisskopf et al. (1988) simply distinguish between a neomarxian (their own) and a neo-keynesian version of the social structure of accumulation approach. The two are seen to differ primarily in the determinants of accumulation: capitalist power versus investment climate and market growth forces. They therefore differ in their analysis of the main causes of crisis. Where they converge is in the emphasis on exogenous, political-historical developments in the shaping of new structures that provide for a way out of the crisis. To the extent that we have presented a rather keynesian version of the régulation approach above, the SSA-approach can be seen as a complementary perspective that may provide important insights in the politics of institutional change.

\section{Olson}

As we are interested in the processes of social choice and decision making leading up to the creation of social institutions, it is useful to look briefly at an explanation of the crisis of Fordism that actually puts collective action at the center of its analysis. In his study on 'the rise and decline of nations' Olson (1982) suggests that a period of stability and growth like that enjoyed by most developed countries in the 1950 s and ' $60 \mathrm{~s}$ will tend to foster the growth of more and more interest-groups that try to produce collective goods for their members. Small, homogeneous groups will be the first to get organized. Later, larger groups also develop solutions to the problem of free-rider behaviour (enjoying the benefits of collective action without paying for it) that is the core problem in organizing interest-groups. These groups effectively try to redistribute social income in favour of their members. By doing so they will more often than not cause total income and efficiency to be lower than potentially possible. They will also have a negative effect on the capacity of a society to adopt new technologies and to reallocate resources in response to changing conditions. In the course of time a society will therefore begin to show signs of 'sclerosis': more and more special rules serving special interests will be introduced and the gap between realized income and potential income will be growing. "Collective action that takes the form of cartelization, collusion or lobbying will generate noncompetitive prices that are inconsistent with equilibrium of the individual participants and that do not clear markets. The noncompetitive prices that are obtained by collective action are, moreover, slow to change because decisions can be altered only by consensual bargaining or by going through time-consuming constitutional procedures." (1982, p.27)

The aim of Olson's analysis is to provide an explanation of macro-phenomena like unemployment that is based on rational individual behaviour. He is critical of Keynesian explanations of unemployment, which he considers to be based on ad hoc assumptions (e.g. sticky wages). He is also critical of the monetarist/equilibrium theories that tend to deny the reality of involuntary unemployment. In his view, unemployment is a real phenomenon that can be explained by the rational hehaviour of individual actors given the possibility of collective action. He starts with a simple analysis of the labour market, showing that the only ones who have 
an interest in keeping wages (and therefore unemployment) above equilibrium levels will be the workers receiving the above-equilibrium wage. He moves beyond this textbook analysis of the monopolistic power of unions to point out (following Malinvaud) that non market-clearing prices on product markets can just as well contribute to unemployment of labour or excess capacity in other product markets: "unemployment due to cartelization in the labour market need not be the most important source of involuntary unemployment; all types of cartels and lobbies need to be taken into account together for a satisfactory analysis of the involuntary unemployment of labor or the underutilization of any other resource." (210)

Olson goes on to present this insight in a general equilibrium framework. Following Clower, he argues that as long as there is no equilibrium on every market, there will be unexploited gains from trade. As long as the vector of prices is not ideal, there will be lower incomes throughout the economy. Aggregate demand will therefore be lower and can indeed be very much lower than if a perfect vector had prevailed. Most economists, so Olson, assume that there is nothing to prevent actors from taking these potential gains from trade. However, there are actors who have an interest in blocking such mutually advantageous trades. And these interests become better organized over time. The important point that is made by Olson is that rational behaviour by individuals leads to sticky prices and wages, because these individuals undertake collective action to serve their interests. There is therefore an important difference between his analysis and much of traditional economic reasoning. The traditional argument says that the economy will achieve optimal results for everyone, if only all actors are allowed to engage in unhampered self-interested behaviour. Olson says that self-interested behaviour in any free society will lead to the formation of interest-groups. Olson thus shows that as soon as we give up the fiction of an economy consisting of atomized actors, institutions come to the fore - because the interest-groups do nothing else than create special rules of behaviour for their members as well as for other groups that they meet at the bargaining table. The prohibition of interest-organizations by force of law is feasible only under a dictatorship, which is not only morally unacceptable, but also economically counter productive, as it leads to other distortions (and the formation of other interest-groups).

Olson argues that differences in performance between countries can be explained by differences in the age and prevailing type of interest-groups in these countries. He distinguishes first between countries with new institutions and those with old. Japan and Germany are the obvious examples of countries whose distributional coalitions have been destroyed by totalitarian government and foreign occupation. After a new and stable legal order had been installed, these countries could grow rapidly, unhampered by the presence of powerful distributional coalitions. The United Kingdom, on the other hand, can be considered as a typical sclerotic country. "The logic of the argument implies that countries that have had democratic freedom of organization without upheaval or invasion the longest will suffer the most from growth-repressing organizations and combinations." (1982:77) A second important distinction is that between countries with encompassing and those with small or narrowly defined interest groups. Encompassing organizations have more incentive than narrow interest groups to increase the prosperity of their 
society. Moreover, in the case of large groups, the costs of redistribution of income may quickly become higher than the amount that is actually available for redistribution. Japan and Germany were double lucky in that their new specialinterest organizations were generally more encompassing than those of the USA and Great Britain. Small countries and countries that have industrialized relatively late would seem to have more chances for the development of encompassing organizations than large, early industrializers.

In an economy full of entrenched and well-organized interest groups, a sudden rise in for instance the price of oil or any other major change that requires the formation of a new set of prices throughout the economy will result in a recession because of slow decision making, crowded agenda and cluttered bargaining tables. It will take considerable time before a new vector of prices will emerge. The stagflation of the 1970s therefore has to be seen as the logical result of a price shock in a set of already sclerotic (UK, USA) or increasingly sclerotic (France, Germany) societies.

As an analysis of the crisis of the 1970 s this analysis presents some problems and is certainly less rich than the approaches we have surveyed above. Problems arise from the fact that Olson argues mainly by way of example but presents his analysis as valid for all times and all places. Reflecting on his examples which range from the Indian caste system to South-African apartheid, it becomes clear that he has said very little about the possible countercurrents in society. History is full of examples of interest-groups that were not successful. A complete theory of social sclerosis would have to explain under what circumstances these counteracting forces can be successful. In a critical review of Olson's analysis, Abramovitz (1983) distinguishes between two explanations for differential performance: those that emphasize the potential for growth and those that emphasize the factors contributing to the speed with which that potential is used. He argues that Olson's thery is of the second type and should be tested together with other theories about factors contributing to growth.

If only because of this lack of attention for other relevant factors Olson's analysis cannot be considered on a par with other analyses of the crisis of Fordism. His book is not meant to be an analysis of that crisis anyway. It tries to provide a general analysis of the economic effects of collective action. The crisis of the 1970s is just an example in Olson's book. There are nevertheless good reasons to mention this study here. First of all, Olson's arguments were not just made within the framework of scientific discourse, but they were also part of an influential political line in the early 1980 s, that was opposed to interest-groups, regulation and corporatism in general and to trade unions in particular. In that sense, Olson's book is part of the general social discourse in the search for solutions to the crisis of Fordism. Another reason to take notice of this study is more theoretical. Olson's book points to specific problems arising from the fact that in a real society, contrary to the traditional economic models of society, co-operation between actors with similar interests is possible and indeed normal. 
In Chapter 2 we discussed the process of the creation of institutions. It was concluded that institutional forms and a fortiori regimes would be the result of (collective) acts of design as well as 'organic' (in-process) discoveries. Olson concentrates on the negative results of collective action, but admits that an economy without interest groups will be unthinkable and/or undesirable. He warns especially against the traditional assumption that government intervention is the only force that may keep an economy from being less competitive (and therefore performing below optimum). "(T)here often will not be competitive markets even if the government does not intervene... Moreover, the absence of government intervention may not be possible anyway, because of the lobbying of special-interest groups, unless we fly to the still greater evil of continuous instability." Together with his observation that the results of actions by encompassing interest groups may be less detrimental to general welfare, this analysis suggests that it may not be necessary (or possible) to follow the liberal notion that all special-interest groups will have to be destroyed in order to create room for the adjustments required to get out of the crisis (the 'new price vector'). Especially where encompassing interest-groups prevail, it may be possible that they find ways of economic adjustment and re-orientation that narrow the gap between potential and realized growth and still respect the basic interests of their members. Adjustment processes will, however, be correspondingly slower.

\subsection{What comes after Fordism?}

In the course of the $1980 \mathrm{~s}$, after it had become clear that the economic crisis could be seen as a fundamental crisis of the post-war institutional forms, the characteristics of 'Post-Fordism' became a central topic of interest in political economy. The contributions to the debate form a complicated mixture of serious analysis, wishful thinking and pure speculation. They describe the ongoing process of social change, but they also contribute to change. Several studies prophesy the direction of future changes, but their authors see their predictions also as programmatic. The prophecies are hoped to be self-fulfilling. Thus we find Kern and Schumann in Germany looking for the 'end of the division of labour' (1984). And Sabel and Piore present us with a 'second industrial divide', i.e. a chance for a new direction in social organization. Others point to the successes of Japanese industry and wonder if maybe Fordism will be followed by Toyotism (Dohse et al. 1985). Others again look at the impact of new technologies and speak of information society.

\section{"information society"}

Information technology plays an important role in many of the speculations about the future structure of social organization. Information technology is the overall designation for a set of technologies that can be used in many different industries. The first applications were in computing, but it was soon realized that all kinds of information can be represented in numbers that can be operated upon. First, the computers were programmed to do calculations; then, the computers were used to program other machines; now, finally, data generated by programmable machines 
are communicated to other machines by means of computer networks. The introduction of (re)programmable machinery and of quick (indeed: real-time) and reliable communications has created new possibilities for the spatial and temporal organization of production processes. The continuous advance in microelectronics is interacting with the constant discovery and development of new applications.

Freeman and Perez (1988) consider information technology to be at the core of a new 'techno-economic paradigm'. Information technology is so pervasive in its effects, that it affects the behaviour of the entire economy. As such it deserves to be differentiated from 'new technology systems', i.e. sets of economically and technically related innovations (see above). A new techno-economic paradigm represents a combination of process, technical, organisational and managerial innovations that embody a quantum jump in potential productivity for all or most of the economy. It involves a radical transformation of the prevailing engineering and managerial common sense for best practice in a wide range of industries. A new paradigm is characterized also by strong dynamics on the relative cost structure of key inputs. Micro-electronics is such a major input showing rapidly falling relative costs, an almost unlimited supply (potentially at least) and applicability in many products and processes throughout the economic system.

Freeman and Perez offer a brief sketch of the characteristics of the 'Fifth Kondratieff' that they expect to be dominated by the information technology paradigm (cf. Table 3.4). They emphasize that in the Fordist system of the 1950s and ' 60 s it was common sense to follow a path of energy- and material-intensive inflexible mass production. With cheapening microelectronics widely available, emphasis is shifting away from economies of scale to economies of scope. Firms try to produce a rapidly changing mix of products and services. Consequently, skill structures and work organizations are changing as well. Freeman and Perez do not pretend to be original in their sketch of 'information society'. Many more or less visionary studies have been published over the past decade outlining some of the alleged consequences of information technology. The added value of the contribution by Freeman and Perez lies in the connection to long wave theorizing. Here, it should remind us that new technologies may not be the cause of the crisis of Fordism, nor in any simple way the solution to that crisis, but that the search for a way out is heavily influenced by the availability of a powerful generic technology.

\section{flexible specialization}

In their widely debated study 'The Second Industrial Divide', Piore and Sabel (1984) argue that the crisis of Fordism provides society with a chance to choose a new direction in the organization of industrial life. In fact, they see the current crisis as more than a crisis of the Fordist system of regulation. Apart from being a 'regulation crisis', comparable to the crisis of the 1930 s, the current period is also one in which the path of technological development is at issue: an industrial divide. The history of capitalism so far has seen only one such divide. That was the divide between mass production technologies and craft-based production systems. It opened up in the course of the 19th century and was closed in favour of mass production. Piore and Sabel argue that there was no economic necessity for this 
Table 3.4

The Fitth Kondrabiev

\begin{tabular}{|c|c|c|c|c|c|c|c|c|c|}
\hline 1 & 2 & & 3 & & & 5 & 6 & 7 & 8 \\
\hline $\begin{array}{l}\text { Approx. } \\
\text { periodisation } \\
\text { Upswing } \\
\text { Downswing }\end{array}$ & Description & \multicolumn{2}{|c|}{$\begin{array}{l}\text { Main 'carrier } \\
\text { branches' and } \\
\text { induced growth } \\
\text { sectors } \\
\text { infrastructure }\end{array}$} & $\begin{array}{l}\text { Key lac } \\
\text { industr } \\
\text { offering } \\
\text { abunda } \\
\text { at desc } \\
\text { price }\end{array}$ & upply & $\begin{array}{l}\text { Other sectors } \\
\text { growing rapidly } \\
\text { from small base }\end{array}$ & $\begin{array}{l}\text { Limitations of } \\
\text { previous techno- } \\
\text { economic } \\
\text { paradigm and } \\
\text { ways in which } \\
\text { new paradigm } \\
\text { offers some } \\
\text { solutions }\end{array}$ & $\begin{array}{l}\text { Organisation of } \\
\text { fims and forms } \\
\text { of cooperation } \\
\text { and competition }\end{array}$ & $\begin{array}{l}\text { Technological } \\
\text { leaders }\end{array}$ \\
\hline $\begin{array}{l}1980 \mathrm{~s} \& 1990 \mathrm{~s} \\
\text { to } \\
?\end{array}$ & $\begin{array}{l}\text { Information } \\
\text { and } \\
\text { communication } \\
\text { Kondratieff }\end{array}$ & \multicolumn{2}{|c|}{$\begin{array}{l}\text { Computers } \\
\text { Electronic capilal } \\
\text { goods } \\
\text { Software } \\
\text { Telecommunica- } \\
\text { tonsequipment } \\
\text { Optical fibres } \\
\text { Robotics } \\
\text { FMS } \\
\text { Coramics } \\
\text { Data banks } \\
\text { Inlormation } \\
\text { services } \\
\\
\text { Digital tolo } \\
\text { cormunications } \\
\text { notwork } \\
\text { Satelities }\end{array}$} & 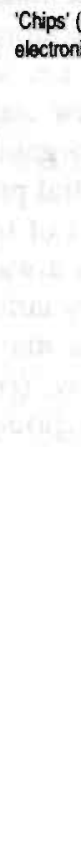 & & $\begin{array}{l}\text { Third generation' } \\
\text { biotechnology } \\
\text { products and } \\
\text { processes } \\
\text { Space activities } \\
\text { Fine cherricals } \\
\text { SDI }\end{array}$ & $\begin{array}{l}\text { Diseconomies of } \\
\text { scale and } \\
\text { inflexibitity of } \\
\text { dedicated } \\
\text { assembly-line and } \\
\text { process plant } \\
\text { partly overcome } \\
\text { by flexible } \\
\text { manulacturing } \\
\text { systems, } \\
\text { 'networking' and } \\
\text { 'econories of } \\
\text { scope: } \\
\text { Limitations of } \\
\text { energy intonsity } \\
\text { and materials } \\
\text { intensity partly } \\
\text { overcome by } \\
\text { electronic control } \\
\text { systems and } \\
\text { components. } \\
\text { Limitations of } \\
\text { hierarchical } \\
\text { departmentaf- } \\
\text { sation overcome } \\
\text { by 'systemation', } \\
\text { 'netwionking' and } \\
\text { integration of } \\
\text { design, production } \\
\text { and marketing. }\end{array}$ & $\begin{array}{l}\text { 'Networks' of } \\
\text { large and small } \\
\text { firms based } \\
\text { increasingly on } \\
\text { computer } \\
\text { networks and } \\
\text { close co- } \\
\text { operation in } \\
\text { lochnology, } \\
\text { quality control, } \\
\text { training. } \\
\text { investment } \\
\text { planning and } \\
\text { production } \\
\text { planning (just-in- } \\
\text { time') etc. } \\
\text { 'Keiretsu' and } \\
\text { similar structures } \\
\text { oflering intemal } \\
\text { capital markets }\end{array}$ & $\begin{array}{l}\text { Japan } \\
\text { USA } \\
\text { Germany } \\
\text { Swoden } \\
\text { Other EEC } \\
\text { EFTA } \\
\text { USSA and } \\
\text { other } \\
\text { Eastern } \\
\text { European } \\
\text { Taiwan } \\
\text { Korea } \\
\text { Canada } \\
\text { Australia }\end{array}$ \\
\hline 9 & \multicolumn{2}{|l|}{ 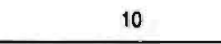 } & & 11 & & 12 & 13 & 14 & 15 \\
\hline $\begin{array}{l}\text { Other industrial } \\
\text { and newly } \\
\text { industrialsing } \\
\text { countries }\end{array}$ & \multicolumn{2}{|c|}{$\begin{array}{l}\text { Some features of } \\
\text { national regimes } \\
\text { of regulation }\end{array}$} & \multicolumn{2}{|c|}{$\begin{array}{l}\text { Aspects of the } \\
\text { international } \\
\text { regulatory regime }\end{array}$} & \multicolumn{2}{|c|}{$\begin{array}{l}\text { Main teatures of the } \\
\text { national system of } \\
\text { innovation }\end{array}$} & $\begin{array}{l}\text { Some festures of } \\
\text { tertiary sector } \\
\text { development }\end{array}$ & $\begin{array}{l}\text { Representative } \\
\text { innovative } \\
\text { entrepreneurs } \\
\text { engineers }\end{array}$ & $\begin{array}{ll}\text { ative } & \text { Political } \\
& \text { economists } \\
\text { urs } & \text { and } \\
& \text { philosophers }\end{array}$ \\
\hline $\begin{array}{l}\text { Brazil } \\
\text { Mexico } \\
\text { Argentina } \\
\text { Venezueta } \\
\text { China } \\
\text { India } \\
\text { Indonesia } \\
\text { Turkey } \\
\text { Egypr } \\
\text { Patistan } \\
\text { Nigeria } \\
\text { Algeria } \\
\text { Tunisia } \\
\text { Other Latin } \\
\text { American }\end{array}$ & \multicolumn{2}{|c|}{$\begin{array}{l}\text { 'Regulation' of } \\
\text { stralegic ICT } \\
\text { intrastucture. 'Big } \\
\text { Brother or 'Big } \\
\text { Sister' state. } \\
\text { Derogulation and } \\
\text { reregulation of } \\
\text { national financial } \\
\text { institutions and } \\
\text { capital markets. } \\
\text { Possibles } \\
\text { emergence of new } \\
\text { style participatory } \\
\text { decentralised } \\
\text { wellare state } \\
\text { based on ICT and } \\
\text { rec-green alliance. }\end{array}$} & \multicolumn{2}{|c|}{$\begin{array}{l}\text { Multi-polarity'. } \\
\text { Regional blocs. } \\
\text { Problems of } \\
\text { developing } \\
\text { appropriato } \\
\text { intemational } \\
\text { institutions } \\
\text { capable of } \\
\text { regulating global } \\
\text { finance, capital, } \\
\text { ICT and } \\
\text { ransnational } \\
\text { companies. }\end{array}$} & \multicolumn{2}{|c|}{$\begin{array}{l}\text { Horizontal integration of } \\
R \text { and } D \text {, design, } \\
\text { production and process } \\
\text { ongineering and } \\
\text { marketing. Integration of } \\
\text { process design with } \\
\text { multi-skill training. } \\
\text { Computor networking } \\
\text { and collaborative } \\
\text { research. State support } \\
\text { for generic lechnologies } \\
\text { and university-industry } \\
\text { collaboration. New types } \\
\text { of proprietary regime for } \\
\text { soltware and } \\
\text { biolechnology. } \\
\text { 'Factory as laboratory'. }\end{array}$} & $\begin{array}{l}\text { Rapid growth of } \\
\text { new information } \\
\text { services, data } \\
\text { banks and software } \\
\text { industries. } \\
\text { Integration of } \\
\text { senvices and } \\
\text { manulacturing in } \\
\text { such industries as } \\
\text { printing and } \\
\text { publishing. Plapid } \\
\text { growth of } \\
\text { professional } \\
\text { consultancy. New } \\
\text { lorms of crath } \\
\text { production linked to } \\
\text { distribution. }\end{array}$ & $\begin{array}{l}\text { Kobayashi } \\
\text { Uenohara } \\
\text { Baron } \\
\text { Bennelon } \\
\text { Noyce }\end{array}$ & $\begin{array}{l}\text { Schumacher } \\
\text { Acki } \\
\text { Bertalanify }\end{array}$ \\
\hline
\end{tabular}

Source: Technicai Change and Economic Theory (1988) edied by Dosi et al. (1988), p.50-57 
to happen. Under different historical circumstances, capitalist development could have taken a craft-based direction (here, they clearly differ from American marxists like Braverman). Similarly, in the current period where mass production is encountering its limits, economic recovery could be based on either a revitalization of mass production strategies (probably on a global scale) or on a strategy of 'flexible specialization'. The latter strategy would to some extent lead back to the craft methods of production that lost out at the first divide and have led a marginal existence ever since.

Important parts of Piore and Sabel's study have been influenced by the régulation approach and the theorizing about the social structure of accumulation. We are here interested only in their distinctive contribution to the debate, i.e. the vision of 'flexible specialization' which they clearly consider to be a much more attractive option than some form of revival of mass production. The vision of flexible specialization is inspired by the economic success of networks of relatively small, technologically sophisticated, highly flexible manufacturing firms in central and northwestern Italy (cf. also Sabel 1982). Flexible specialization is presented as a strategy of permanent innovation and permanent change, based on flexible equipment, flexible (multi-skilled) workers and a sense of community between firms that directs competitive energies in the direction of mutually beneficial innovation. Piore and Sabel argue that firms and economies will drift to either direction at the divide, depending on the extent to which national institutions have become adapted to mass production. In that respect they see more chances for flexible specialization in Italy, Germany and Japan, where there are still important vestiges of craft tradition, than in France or the United States. There are two reasons why economies might mow be more inclined to follow the path of flexible production techniques than at the first industrial divide. The first one is the availability of computers that allow for flexible systems. "The computer is thus a machine that meets Marx's definition of an artisan's tool: it is an instrument that responds to and extends the productive capacities of the user." (Piore \& Sabel 1984, p.261) The very flexibility of this 'tool', however, would also make it suitable for a continuation of mass production. Computers make a change in direction possible and maybe easier, but they do not force the economy in a particular direction. The second reason for the feasibility of 'flexible specialization' is the presence of powerful configurations of demand patterns, industrial structures and social institutions in various countries and regions, that allow for a dynamic development of the economy.

At the core of these configurations that have such diverse antecedents as the prewar Japanese zaibatsu, the German machine-tool industry and the clothing manufacturers of the Emilia-Romagna, Piore and Sabel discern a single model of microeconomic regulation. That model is characterized by flexibility bounded by specialization (in a certain product, or a certain style), by a delicate balance between intense competition in product innovation and structural limits on competition in other dimensions (e.g. price competition), and finally by a sense of community that is fed by the presence of benefits and services that are only available to members of the community. In flexible specialization, "it is hard to tell where society (in the form of family and school ties or community celebrations of 
ethnic and political identity) ends, and where economic organization begins. Among the ironies of the resurgence of craft production is that its deployment of modern technology depends on its reinvigoration of affiliations that are associated with the preindustrial past." (Piore \& Sabel 1984, p.275) This reference to preindustrial times has brought the authors a lot of criticism and the reproach of romanticism. On the other hand, the reference to craft traditions made for an easy connection to traditional marxian lines of argument and long-standing political sentiments in the labour movement, where the destruction of crafts is often still considered as the original $\sin$ of capitalism. Not least because the vision of flexible specialization was embedded in honorable traditions, it inspired not just debate, but also practical policies emphasizing institutional, social and regional aspects of innovation.

In the same year that Piore and Sabel published their study, a comparable vision was put forward by Kern and Schumann in Germany. Although their book 'Das Ende der Arbeitsteilung?' (The End of the Division of Labour?) had a much more limited focus, it essentially had the same message, namely, that the new technologies were offering chances for a reversal of the trends that had characterized industrial labour at least since the days of Taylor. Kern and Schumann are industrial sociologists, who gained their reputation already in the early 1970 s, when they carried out a large empirical research project on workers' consciousness and work organization in various branches of industry (Kern \& Schumann 1974). In this study they defended the so-called 'polarization thesis', which says that the working class is becoming more and more divided into two parts: on the one hand unskilled workers with degraded work and on the other hand highly skilled, professional workers. ${ }^{4}$ The 1984 book is a result of an investigation in the same branches and the same places that were looked at a decade earlier. To put it very simply, the authors argue now that polarization has been replaced by a uni-directional movement. They discern a trend towards upgrading and re-integration of tasks, i.e. towards the end of the division of labour.

Of course, Kern and Schumann were careful enough to put a question mark to all that (cf. the title of their book). They also pointed out that the trend would benefit only a relatively small group of 'rationalization-winners'. Their description of current trends in work organization is based on the estimation that degraded and de-skilled jobs have been or will be automated in the near future. There will be less and less of this kind of 'residual' work left in the factories of the future. All remaining human tasks will be combined in jobs that require a variety of skills. Direct production work, that became the realm of unskilled labour in the age of Fordism, will be skilled work again. Kern and Schumann saw signs of these 'new production concepts' in many of the places they investigated. Like Piore and Sabel, they tended to proclaim these signs as so many proofs that their vision was in fact not a vision but an empirical trend. At the same time, they knew that the new production concepts were still no more than a couple of islands scattered in a sea of Taylorism. Consequently, they urged workers, works councils and unions to use

${ }^{4}$ In the carly seventies, Michael Piore was also concerned with labour market segmentation and internal labour markets, cf. Doeringer \& Piore 1971. 
this opportunity and support such concepts against the remaining old-fashioned managements (cf. also Prakke 1989).

\section{Toyotism}

No enterprise and no country that is searching for a way out of the crisis of Fordism can afford to neglect the lessons that might be learnt from Japan. The crisis of Fordism in North America and Western Europe may not have been caused by the rise of the Japanese economy, but no description of the global economy of the $1970 \mathrm{~s}$ and $1980 \mathrm{~s}$ can be complete without an account of that phenomenon. Compared to the visions of 'information society' and the wishful thinking of the proponents of 'flexible specialization' and 'new production concepts', 'Toyotism' is a quite different contribution to the debate about the possible characteristics of a 'Post-Fordist' economy. Toyotism is not a vision. It is a reality. The concept refers to the impressive competitive successes of Japanese manufacturing industry over the past decade. These successes have not been limited to the automobile industry, but the inroads made by Japanese car manufacturers on the North American car market clearly had an additional symbolic value. Ford was the symbol of the 'American system' of mass production, and it seems only logical that the name of Toyota is now used to designate a production system that may replace Fordism. Other names, like Sony-ism or Honda-ism, have also been used, but there are good reasons to stick to Toyotism. Toyota is not just the largest Japanese car manufacturer, but in many ways more original in its methods and therefore in a way more 'Japanese' than other Japanese firms. ${ }^{5}$ Whereas many Japanese firms copied Western management methods after the war and were very successful at it, Toyota developed its own production system quite early in the race, which then turned out to be so successful that it was adopted by many other Japanese firms in the 1970 s and became known worldwide as 'the' Japanese production system.

Of course, 'the' Japanese production system doesn't exist. The reality of Toyotism at Toyota is different from that at Nissan, which again differs from that at Matsushita. Toyotism as a model that could be adopted by others is obviously an abstraction. Similarly, Japan is a reality, and so are the successes of its industries, but the Japanese model is not. The construction of such models, however, is an important part of the search for alternative institutions to overcome the problems of existing Fordist institutions. We will deal with the Toyota production system in later chapters. Here we want to raise the question if it is possible to identify not just a Toyotist production system but also, as in the case of Fordism, a whole set of Toyotist institutions that make up an alternative mode of regulation.

The first question to ask, is whether the postwar economic history of Japan can be considered as a form of 'intensive accumulation with mass consumption'. It would seem that this is indeed the case, although there are some differences with the

5 This is also true for the way its factories have absorbed the rural population of the area where Toyota is located, much in the same way as the manufacturing sector in general has interacted with the still relatively large rural population. Nissan, on the other hand, was located mainly in Tokyo and always drew its workers from the urban population. 
North American and European patterns. The Japanese population had to wait much longer before it was to participate in mass consumption at Western levels. Post-war accumulation in Japan is characterized by a very high savings (and investment) rate. A substantial share of the national product, moreover, was exported. The proceeds of the exports were used to pay for imports of raw materials and energy, whereas imports of consumer goods were severely restricted. Exports gave an important boost to Japanese industry, allowing it to achieve some minimum levels of scale. In recent decades, huge surpluses in foreign trade were achieved, which may suggest a pattern of mass production at home supported by mass consumption abroad. That, however, would be an exaggeration of the importance of exports to the Japanese economy: "Japan's growth did not depend nearly so much on exports as it did on the development of the domestic market." (Johnson 1982, p.15) Domestic demand was allowed to expand steadily after the mid 1950s, as part of a well-managed, state-controlled system aimed at high economic growth through high investment financed by high forced savings and facilitated by protectionist trade policies.

The second question is, if this regime of accumulation was regulated by Fordist institutional forms. In Japan, probably more than in any other country, Fordist institutional forms were directly imported and indeed formally imposed after the war by the victorious Americans. Here too, however, it didn't take long for some specifically Japanese features to develop, related to Japanese political and social history. These Japanese peculiarities became the object of intensive investigation and debate when the Japanese economy started to show its competitive strength and skillfully mastered the problems generated by the two oil crises. Different authors pointed to different institutions to explain Japan's phenomenal success, often over-emphasizing the importance of a single institution. Some emphasized the role of the state, others the Japanese banking system; some pointed to the industrial relations system and others to supplier-assembler relations; others again looked for an explanation in the institutions of the labor market, the training system or the organization of work. At some point, adding up all these different Japanese institutions and considering their mutual coherence, the question arises if this ensemble of institutions should still be called Fordist. In view of the crisis of Fordist economies and faced by the success of the Japanese economy, it seems more logical to argue that at some early stage Japanese Fordism began to depart significantly from Fordism in North America and Europe. The picture of an alternative mode of regulation emerges that, if only for lack of a better name, may be called 'Toyotism'.

Of course, the construction of a complete alternative mode of regulation tends to exaggerate differences with other countries and to underemphasize similarities. As in the case of the 'visions' mentioned above, however, this is natural and useful within the framework of a search for alternative institutional arrangements. From this perspective, Toyotism as a social system differs from Western Fordism in the organization of practically all basic capitalist relations. In the relation between the state and the economy, the state has been much more active than in the traditional Fordist (Keynesian) model. It is 'active' and not 'interventionist' in the sense that there is constant interaction between the state bureacracy and industry leadership. 
Its role in terms of transfer payments and fiscal policy is minimal in comparison to the efforts it has undertaken to promote the growth of Japanese industries and the structural modernization of its economy. The activities of the Japanese state in the first post-war decades were often more similar to those of developing countries than to those of the advanced industrialized (Fordist) countries. They were very protectionist, blocking not just imports from other countries, but also direct investment, favoring licencing agreements and other forms of technology transfer instead. The expansion of Japanese exports of industrial products, moreover, was greatly supported by an exchange rate policy that kept the Yen undervalued for several decades. The difference between the Japanese economy and the economies of developing countries was, of course, the presence of an industrial base that had been large enough to support an immense war effort during several years. Although it had been partly destroyed during the war and was further dismantled by the American occupying forces, it offered important building blocks for the national program of economic recovery, which was soon to receive additional impetus from the Korean War.

Responsible for the national recovery program was the Ministry of International Trade and Industry (MITI). Some observers were inclined to attribute the achievements of the Japanese economy in the '70s and ' 80 s almost completely to policies of MITI (cf. Johnson (1982) for a balanced historical presentation of this argument). Considering the dismal failure of the centrally planned economies and the uncertain effects of planning activities in other capitalist countries, the capabilities of the MITI-planners acquired almost mythical proportions. Of course, the MITI bureaucrats did not have perfect foresight and they did not always realize their plans. They did have much more power to support and implement their plans than bureaucrats in Western capitalist countries; and for the development of their plans they could rely on close interaction and cooperation with private industry. Ironically, the bureaucrats had received their power from the American occupying forces, that had dismantled the other poles of power in Japanese society: the military and the zaibatsus (see below). The willingness of industry to engage in constructive debate with the bureaucrats was of course a function of that power, but it also derived from the insight, acquired in a series of harsh experiences (including crisis and war), that consensus and cooperation can be more advantageous than unbridled competition for all parties concerned, especially in a developing economy. It was MITI that at a very early stage decided to create comparative advantage for Japanese industry in capital-intensive and technologyintensive industries (iron and steel, petroleum refining, automobiles, machine tools, electronics). The automobile industry is a typical example of that approach. "Public investment laid down the infrastructure to permit a swift rise in auto usage, the domestic market was closed to outsiders, and a competitive auto components industry was established under government leadership. Competition between the assemblers did the rest." (Zysman 1983, p.240) In the 1950s and '60s (the 'high speed growth' years) "Japanese-style government-industrial cooperation came as close to squaring the circle - to achieving social goal-setting without the disadvantages of socialism - as any form of mixed economy among all the historical 
cases." (Johnson 1982, p.311) ${ }^{6}$ 'High speed growth' resulted in the rise of rich and powerful enterprises and a corresponding decline in power for the bureacrats. Partnership between government and business became more equal and therefore sometimes more contentious, but there is no doubt that it did remain in many respects a real and effective partnership.

Cooperation in Japan is not limited to the government-industry nexus. A similar phenomenon in Japanese inter-firm relations has also attracted the attention of Japan-watchers. Before the war, Japanese industry had been organized in powerful 'Zaibatsus', i.e. conglomerates of firms usually grouped around giant trading companies. The phenomenon of Zaibatsu seemed similar to that of the giant firms that dominated Western economies and the Americans insisted on dissolving them in the same way that German groupings like the IG Farben and Krupp were being dismantled. The Zaibatsus, however, were not fully integrated enterprises, but networks of cross-ownership, co-operation and interdependence. It didn't take long for new but similar groupings to re-appear on the Japanese scene, now called Keiretsu, usually grouped around large banks. The dominance of banks in these groupings made them more dynamic than the zaibatsus, which were intent on the monopolization of marketing channels. The traditional (maybe one should say 'Fordist') concept of competition and the accompanying competition policies lack a clear understanding of this phenomenon. The dominance of large firms ('monopolies') in de Fordist mode of regulation shouldn't be equated with the dominance of Keiretsu in the Japanese economy. The important difference is that Keiretsu does not mean the elimination of competiton, but rather the organization of sometimes very intense competition. That competition, however, is controlled, i.e. limited in its harmful effects and directed in specific directions both by state actions and by the cooperative relations between firms and banks. As we shall see in later chapters, the well-administered mixture of competition and cooperation can be found not just in horizontal relations between competing firms, but also in vertical relations between suppliers and assemblers. In both cases cooperation turns out to be an interesting alternative for the Fordist penchant for merger and acquisition.

In Japan, 'organized capitalism' (Hilferding) doesn't imply monopoly capitalism. Similarly, a traditional marxian concept like 'finance capitalism' doesn't describe adequately the shaping of the 'money relation' by the Japanese financial system. As noted above, large Japanese banks are at the core of major groupings of manufacturing companies. They help to regulate the relations between the various parts of the keiretsu and control the intensity of competition. The banking system absorbs household savings and uses them to finance the corporate sector. Credits from banks are the major source of funds for companies. The stock market is not

6 The main instruments used in this cooperative relationship were "selective access to governmental or government-guaranteed financing. targeted tax breaks, government-supervised investment coordination in order to keep all participants profitable, the equitable allocation by the state of burdens during times of adversity (something the private cartel finds it very hard to do), governmental assistance in the commercialization and sale of products, and governmental assistance when an industry as a whole begins to decline." (Johnson 1982, p.311) 
a means of raising new funds for industry from the households sector, but is basically an intercompany and interbank market. Government has kept interest rates low, which also has limited the size of the bond market. The lack of alternatives for bank lending didn't have to trouble companies, however, as long as extensive bank financing was available. This was indeed the case, but there was never enough. The artificially low interest rates created a permanent excess demand for credit. The banks had to resort to some kind of credit rationing between their clients. Although this gave the banks the power to decide in what order their clients would be served, it also provided the Japanese government with an instrument to direct the lending practices of private banks. The pressures on the commercial banks for funds were so high that they loaned in excess of their stipulated ratio and had to borrow from the Bank of Japan to cover their commitments. The Bank of Japan is not an independent institution, but follows the policies of the Ministry of Finance. Consequently, it provided only extra funds to banks whose loan policies were in accordance with government priorities. "The political and policy strategies of the Japanese government would have been difficult to accomplish within the constraints of a capital market-based financial system with freely moving prices and an elaborate securities market. (...) The degree to which government's view prevails within particular sectors depends on the international competitive strength and financial position of their major companies." (Zysman 1983, p.250)

Again, what we see is not simply a system with powerful banks, but one where the undeniable power of the banks is circumscribed by the policies that have been developed by government agencies in close interaction with industry. "The speed of expansion in sectors such as automobiles and steel involved staggering investment sums. Whereas the Japanese produced only 160,000 cars in 1960 , they were producing 3.1 million cars a year by 1970 and over 8 million a year in 1980 . Such rapid expansion was of necessity debt financed, but neither companies nor banks could have managed the debt without special tax arrangements and a policy of diffusing lending risk. (...) Despite seemingly risky corporate financial structures, the system remains stable because government concern with the well-being of firms in favored sectors is seen as an implicit guarantee of the bank loans made to them." (Zysman 1983, p.241/3)

Finally, some remarks must be made on the wage relation in Toyotism. It too has been described as the key to Japan's economic success. In a later chapter we will deal extensively with the Toyota production system (the 'production norm'). Here we will focus on what Japanese employers have called the 'three sacred treasures', i.e. the lifetime employment system, the seniority wage system and enterprise unionism. Although it is widely known by now, that the lifetime employment guarantee is applicable to only a minority of Japanese workers ( $28 \%$ according to Bergmann 1990), it continues to capture the imagination of outside observers. The fact that large Japanese enterprises provide their core workers with a lifetime employment guarantee has no doubt greatly contributed to the willingness of these workers to identify with their enterprise and cooperate in rationalization programs. But even workers without an employment guarantee will find it attractive to identify with their firm and stay there as long as possible, because the wage 
increases with the number of years one has worked with a firm. Both arrangements have made it easier to invest in training programs, because the firm can assume that workers have little interest to move to a competing firm. Firm-specific training in turn, tied as it is to a complex system of evaluations and rewards, makes it even less attractive for a worker to 'exit' his firm. Lifetime employment presumes a willingness on the part of the protected workers to do almost any kind of job and if necessary to move to a distant factory or subsidiary where work is available. The Japanese labour market consequently is characterized by strong segmentation: there is an internal labour market inside the large firms for the workers with employment guarantee; there is a labour market for 'temporary' workers, who may work in the factories of large enterprises for many years, but are formally employed by a subcontractor; there is a labor market serving the needs of the small firms, who do not give their workers an employment guarantee; there is another market for older experienced workers who are leaving the large firms but are still willing to work. The thus accentuated dividing lines in the national work force and the labour market have effectively blocked most efforts to create industrial unions and supported the rise of enterprise unionism instead.

In the background of these institutions is the specific 'dual structure' of the Japanese economy, with a small number of large firms and conglomerates on the one hand and a large number of small enterprises on the other. Lifetime employment forms an incentive for large firms to operate at high and constant capacity. The small business sector provides the large firms with additional capacity to cover fluctuations in demand. It also absorbs many older workers, whose 'lifetime' employment expires when they are 55, causing them to search for a new job in order to improve their suddenly diminished income. The small business sector functions as a shock absorber for the Japanese economy. The shocks are absorbed mainly by the workers employed in this sector, where wages are lower and working conditions worse than in the big firms (and comparatively more so than in other capitalist countries). But even the higher wages in the big firms do not guarantee a quality of life that is available for comparable workers in other advanced capitalist countries. Buying power is not only limited by relatively high prices for several amenities, but also by the need to set funds aside for old age and other eventualities, leading to a specifically Japanese 'consumption norm'. "(T)here are some strong external pressures that encourage the Japanese to save: a comparatively poor social security system; a wage system that includes large lumpsum bonus payments twice a year; a retirement system that cuts a worker's income substantially before he reaches the age of 60 ; a shortage of new housing and housing land, as well as a premium on university education for one's children, both of which require large outlays; an underdeveloped consumer credit system..." (Johnson 1982, p.14)

Even an extremely brief description of the Japanese wage relation cannot be complete without pointing to a major difference with the wage relation in Western countries. Quasi lifetime employment guarantees are also available in other countries, either given by a strong firm (IBM is often mentioned as an example) or provided by legal or contractual protection of employees. Neither is it uncommon for workers in Western countries to identify with 'their' enterprise and 
the products it produces. Even the phenomenon of enterprise unions can to some extent be compared with firm-level activities of trade unions and with legally constituted works councils (e.g. in Germany). Still, there remains a difference with the Japanese wage relation, which Deutschmann (1989) has characterized as the difference between 'generalized exchange' (in Japan) and 'balanced exchange' (in the West). The point is not so much that the exchange between employers and workers in Japan is somehow 'unbalanced', but that it is diffuse, organized along a much longer time perspective and loaded with emotional meanings. Because of that, the Japanese firm can be likened to a family or a clan, rather than to a machine (the bureacracy model). In this perspective, it is rather odd that the recent MIT study on the Japanese production system was called The machine that changed the world' (Womack et al. 1990). The same kind of social relations often prevail in the field of interest representation where the enterprise unions depend more on informal contacts and off-the-record communications with management than on formal bargaining sessions.

The different character of the Japanese wage relation expresses itself among other things in a strong emphasis on the group as organizational unit and on the integrating role of the lower levels of the relatively elaborate firm hierarchy. Tasks and responsibilities are mainly defined at the group level and since group performance depends partly on the social cohesion of the group, the latter is a main responsibility for the group leadership. This has led to widely discussed phenomena like the willingness to work overtime, the reluctance to take up holidays or to stay home in case of illness, and the fact that a lot of free time is spent with fellow workers instead of with the family or in other non-enterprise related activities. Individual wages are related to group performance, but not exclusively so. On the contrary, emphasis on the group as basic social and organizational unit is combined with an elaborate system of individualized evaluation and rewards. "The structure of work organization and the rules of compensation are such that individual competition sustains group performance and thereby the status of the group supervisor - a complex relation in which various components of cooperation and competition mutually support each other." (Bergmann 1990, p.40; transl. BD)

Key words in the description of Toyotism are integration, cooperation, consensus and coherence: between state and economy, between manufacturing firms and banks, between assemblers and suppliers, between employers and unions, between workers and supervisors. These characteristics are at first sight practically the opposite of those of the Fordist-Taylorist system, which proposed an ever increasing division of labor as main organizing principle. Of course, the principle of division of labor is not absent in Toyotism, just as there are integrative mechanisms operating in a Fordist regime. In that sense, the model of Toyotism is a social construct that simply supports a movement of the social pendulum in the other direction, away from the limits and indeed excesses of Fordism. It is certainly not a coincidence that similar values and orientations also play a prominent role in the other alternative visions like information society (emphasizing integration through electronic information and communication technology) and flexible specialization (emphasizing regional cohesion and cooperative networks between 
firms). In this respect it is also significant that Toyotism is usually not associated with advanced technology. It is not connected to a higher level of mechanization than Fordism. Although Japanese manufacturers have been highly successful in some high tech areas and although they are known to have introduced some advanced techniques in production, notably robotics, technology is generally not considered the basis of their competitive strength. In the car industry, fact-finding missions from Europe and the United States were generally disappointed by the level of technology they found in Japanese plants in the second half of the 1970s. Their general reaction was, that 'there is nothing there that we couldn't do, if we would think it would pay'. They did find a different kind of work organization, a different style of production management, and different employment practices that departed on some essential points from the accepted principles of Fordism. What they often didn't realize, was that these organizational and institutional differences also accounted for the fact that the experiments with new technologies obviously did pay for the Japanese.

The 'production norm' of Toyotism has slowly been discovered and indeed constructed over the past decade. Cut loose from its roots in Japanese culture and history, it is now presented as a set of widely applicable management techniques, organizational rules and patterns: a model for the successful organization of production. Just as in the case of 'the American system', adoption of these techniques by firms in other countries will lead to adaptations and modifications in accordance with local culture, tradition and legislation. In some cases, local culture, tradition and legislation may in turn be modified. Although elements of the Toyotist production norm are gaining popularity in Western countries, it remains to be seen if the other institutional forms of Toyotism will diffuse in a similar way. Whereas the production norm belongs to a large extent to management's prerogative (and even there new agreements have to be struck between managements and unions), many more parties are involved in the construction of other social institutions. Not all Japanese institutions will be considered worth copying. In Japan, Toyotist arrangements also include a consumption norm, i.e. a specific income distribution and a specific level of transfer payments, that would seem to depart too strongly from the European Fordist welfare state to be acceptable there. It should be noted, however, that Toyotism is a coherent social system. The various parts of the system are complementary and supportive of each other. Simply copying some selected parts may therefore not bring the desired results in the sense of a functioning regime of accumulation. More creative action, search and bargaining will then be necessary.

In the remainder of this book, we will be mostly concerned with the search for new institutions within the framework of one particular branch of industry. At the level of a single branch of industry, national financial systems and international monetary arrangements, the role of the state and macro-economic consumption patterns cannot be dealt with, or only partially so. In that respect, the following chapters can also be only a partial description of the search for workable arrangements to overcome the crisis of Fordism. 
PART II

Chapters in the search for a post-Fordist order 
. 


\section{Introduction to Part II}

The following five chapters have been written and published between 1982 and 1990. They are published here in the same order that they were produced. No effort has been made to update them or to revise them with the knowledge that is available in 1992. Chapter 9 in Part III will provide a retrospective overview taking account of recent developments. Apart from practical considerations, there are also substantive reasons for publishing these papers in the order and form that they were originally produced. Together they provide a panorama of the search for new, post-Fordist arrangements in the automobile industry. Their order reflects the sequence in which various aspects of the industrial order became the subject of experimentation and public debate. Their contents reflect the themes and viewpoints that were prominent at the time of writing. As such, these papers can also been seen as contributions to the search for post-Fordist institutional forms.

In the 1970s, much of the debate was still dominated by the Fordist paradigm. Economies of scale and low wage costs were considered the most important sources of competitive advantage. The logic of mass production, mechanization and standardization pointed to a relocation of production to countries with a large supply of low-paid, unskilled labour. The rise of Japan as a car exporting country was also seen in that light. Chapter 4 reviews this relocation debate.

By the early 1980 s, after the second oil crisis had shaken up the Western economies, attention focused on the conditions for survival of mass production in the advanced capitalist countries. Fordist answers consisted of mechanization and union busting, but there were also developments that pointed in a different direction. In some places and countries, new production concepts were developed, based on the use of skilled labour both in mechanized and non-mechanized sections of the production process. Co-operative forms of industrial relations were drawing a renewed interest. It was emphasized that mass production was becoming more and more differentiated, requiring skill-based and flexible forms of organization. Chapters 5 and 6 are concerned with these developments.

Flexibility became one of the management buzz-words of the $1980 \mathrm{~s}$. The ability to offer a large variety of products and react quickly to customer orders can only be achieved at acceptable costs, when inventories are low and logistics well organized. This raised questions concerning the merits of another typically Fordist organizational form: the large enterprise with a high level of vertical integration. The Japanese had gone different ways here and set new standards that forced all car manufacturers to reconsider their make-or-buy decisions. Chapter 7 deals with the changing relations between car manufacturers and their suppliers.

By the late 1980s, it had become abundantly clear that the competitive advantage of the Japanese car manufacturers could not be explained by a low wage level. The 
Japanese seemed to perform better on almost every count. Was it possible that they had discovered a model for flexible mass production in high wage countries? If so, could that model be adopted in other countries, or was it too Japanese to be copied in Western countries? These are the questions under investigation in Chapter 8. 


\title{
4. Maturity and Relocation in the Car Industry
}

\author{
4.1 Foreign investment, multinational corporations and relocation of \\ industry \\ 4.2 The theory of relocation and the car industry in the 1970s \\ maturity and conditions for relocation \\ the oil crisis and the Japanese challenge \\ 4.3 Production and trade of automotive products in the 1970s \\ before the crisis: the situation in 1973 \\ production and trade after 1973 \\ 4.4 Alternative strategies for the automotive firms \\ maturity and rejuvenation \\ relocation and government policies \\ 4.5 Some final considerations on the theory of relocation
}

Theories of international trade and investment have predicted that the production of mature industrial products would tend to move to developing, so-called lowwage countries. In this article we shall consider these theories of relocation against the background of production and trade in the world passenger car industry.

\subsection{Foreign investment, multinational corporations and relocation of industry}

Over the past twenty years the theory of foreign direct investment has closely followed the practices of multinational enterprises. As these have increased in number and spread all over the world, theories explaining their existence have also increased in scope, incorporating the multinational enterprise in a general picture of the growing world economy. Firstly, if we take Hymer's seminal dissertation (1960) as a convenient starting point, direct foreign investment was explained as caused by some specific advantage (usually some kind of knowledge) possessed by the investing firm, which could best be exploited by founding foreign subsidiaries. The multinational enterprise was depicted as essentially offensive, monopolizing its advantages on foreign markets. The historical background to this was formed by the stream of investment by US firms in the newly established European

\footnotetext{
${ }^{1}$ Published in Developmens and Change, Vol. 15 (1984), pp. 223-250. Research for this chapter was done under contract for the International Institute of Management in Berlin (West) within the framework of the German contribution to the MIT project on the Future of the Automobile (cf. Altshuler et al. 1984). The author is indebted to Dr. Andrew Black and to an anonymous referee of Development and Change for useful comments on earlier versions of the chapter.
} 
Common Market ('the American Challenge). In the course of time, some more defensive (or perhaps better) competitive features were introduced into the picture. Foreign direct investment came to be seen as an outflow of oligopolistic competition on the home market (Caves 1972) and/or as part of the struggle for market shares in the host countries (Knickerbocker 1973). Not only investment in developed countries, but also the competitive introduction of subsidiaries in developing countries was integrated into a theoretical framework which predicted the introduction and reproduction of oligopolistic structures in national markets all over the world. Finally, the growth of multinationals seemed to cumulate in an opening up of these national markets as several of the important developing countries switched from import-substitution to export-promotion policies. As a result, oligopolistic competition could be reorganized on a world scale. Attention was caught not so much by specific ownership faculties of the firms as by cost advantages of specific locations. Firms were seen to be buying, producing and assembling at different locations, searching for the cheapest combination possible. This 'world-wide sourcing' (Adam 1973) was seen as the text step towards integrating the developing economies into the industrial economy of the developed countries, creating a true 'world economy'. Improved organizational production and communication networks within the multinational enterprise and infrastructural (communications, banking) conditions enabled a new international division of labour (Fröbel et al. 1977).

We are not interested here in an evaluation of this process, depending for instance on one's estimate of the income and knowledge-generating importance of worldmarket production for developing countries, and on which there is much controversy in the literature. Here, we wish only to emphasize what seems to be the general trend, i.e. to expect a shift of labour-intensive (parts of) production processes to developing, low-wage countries as a general consequence of the world economy. Not only that, but in the long run these corporations with their 'global reach' (Barnett \& Müller 1974) were expected to create their own world order, new global institutions replacing the nation-state, which seemed in the words of Charles Kindleberger: 'just about through as an economic unit' (quoted in Gilpin 1975, p.220).

And indeed, practice seemed to follow the pattern outlined as long ago as 1966 by Raymond Vernon in his article on the product life cycle and international trade and investment. The concept of the product life cycle says that all products go through a process of increasing standardization in characteristics as well as in methods of increasing standardization in characteristics as well as in methods of production. In its 'infancy' a product is still adaptable; development activities continue while the market is explored. In order to be able to manage frequent changes, production is located in the home country, keeping $R \& D$, production and firm management close together. At this stage cost considerations are less important as price elasticity of demand is usually quite low. As the product 'matures', the need for flexibility declines and management's attention shifts from product characteristics to production costs. At the same time, demand for the product will increase in foreign countries, especially where demand conditions approach those of the home country. At first, foreign demand will be satisfied by 
exports from the home country, but after some time production will be taken up in the foreign country: a decision usually taken after some threat appears to the monopoly position of the firm, e.g. domestic producers and/or tariff barriers.

In the next stage of the product life cycle the product is mature and its essential characteristics no longer change. Vernon speaks of a standardized product, but emphasizes that standardization does not prevent a great deal of differentiation. At this stage, it is possible that production of the standardized product will all but cease in the home country and imports will take its place. Production will be located in the least-cost location. This could be another developed country, but it might also be a developing country, especially if the product requires significant inputs of labour. other characteristics, which would make a mature product suitable for production in a developing country, are a high price elasticity of demand and a high individual value of the product, so that significant freight costs may be absorbed. Finally, Vernon suggests that product whose production process does not rely upon external economies will be more obvious candidates for relocation than those that require an elaborate industrial environment.

As an example in this stage of the product life cycle Vernon mentions standardized textile products. By the mid-1970s, imports from developing countries accounted for more than 60 per cent of total imports of clothing by the OECD countries (note, however, that these imports covered only a fraction of total demand in these countries (UNIDO 1979, p.156)). Textiles and apparel also figure prominently in the 1977 study by Fröbel et al. Following Adam, these authors show that for some products it has been possible to 'forget' the middle stages of the life cycle and to switch immediately from the innovative stage in the home country to the imports stage, using so-called free production zones offered by developing countries to manufacture a product, or part of it, which is not (yet) in demand in the country itself. Apparently, multinational corporations were able - at least in some industries - to shift production of high-income products to countries with a much lower wage rate without a concurrent loss of labour-productivity. In a later article (1979) Vernon has also pointed out that the existence of large multinational networks of producing-units has created a situation in which even a new product is not necessarily produced first in the country where it is to be marketed.

In the following, we shall use 'relocation' to refer to all possible ways by which multinational corporations can use foreign subsidiaries and other sources to serve demand in their home countries which was formerly met by production within the home country itself.

\subsection{The theory of relocation and the car industry in the $1970 \mathrm{~s}$}

maturity and conditions for relocation

Around 1970 , the passenger car industry was generally considered to be a mature industry. The technical design of cars had not changed fundamentally for several decades. Styling had become a major aspect of competition and 'planned 
obsolescence' seemed to be an invention of the car industry (Wells 1980, p.274). In fact, Vernon, in his 1966 article quoted above, mentions the passenger car as an example of a 'thoroughly standardized product'. Maturity also showed in the structure of the industry. Only a few dozen companies served the world market with, for instance, only four firms producing in the giant US market. Barriers to entry into the industry had become very high since existing producers exploited manufacturing economies of scale to such an extent that the minimum efficient scale of production had reached at least 500,000 and more likely 1,000,000 units (White 1977, p.183-84). The production process was well known and parts of it highly automated. The automobile engine plant had become the classic example of automation in industry. In terms of demand, the share of replacement procurement, also an indicator of maturity, had been growing significantly. In 1970, for instance, 6.7 million passenger cars were newly registered in the EC (EC 9, excluding Ireland), but the total number of cars registered in these countries had increased by only 3.7 million, indicating that almost 50 per cent of demand had a replacement character ${ }^{2}$. Finally, consumer protest and government regulation can also be considered as a sign of maturity and the car industry had its share of both. In the densely populated European countries, in particular, growing opposition was voiced to further expansion of the highway network. All developed countries showed increasing concern about car safety and about air-pollution caused by motor vehicles, which resulted in various types of government regulation.

Keeping to Vernon's scheme, it might be said that the car industry had already reached a 'maturing' stage before the Second World War which became visible in sizeable investments by American producers in Europe. After the war, investment in Europe by American car manufacturers continued and, in addition, there was investment in developing countries, mainly in Latin America where American firms were joined by several of their European competitors. By the early 1970s, therefore, the car industry appeared to be a mature industry, dominated by large multinational corporations with production facilities in several developing countries.

What about the other characteristics that make a product suitable for production in low-wage countries? Cars have a high individual value, but they are bulky. Freight costs are not negligible, but Japanese exports have shown that they are not insurmountably high. Demand is certainly not price-inelastic. On the other hand,

\footnotetext{
${ }^{2}$ Unless otherwise indicated, the data used in this article are based on the following statistical sources:

- OECD: Trade by Commodities, Series B and C, several years (trade in passenger cars, trucks and parts: SITC (rev.1), 7321, 7323, 7328, SITC (rev.2), 781, 782, 184; autom. electrical equipm. SITC (rev. 1),7294).

- UN Statistical Yearbook, several years (data on production and assembly of motor vehicles).

- UN yearbook of International Trade Statistics (trade in internal combustion engines: SITC (rev.1), 7115, SITC (rev. 2), 713; trade in automotive electrical equipment: SITC (rev. 2), 7783), several years.

- VDA, Tatsachen und Zahlen aus der Kraftverkehrswirtschaft (data on registration, production and exports of passenger cars), several years.
} 
the questions of labour content and reliance on a complex industrial environment require some more attention.

Although the production of cars has become a large-scale enterprise which demands enormous capital outlays, the industry can still be called labour-intensive. Assets per employee, for instance, are still well below the average for all industries (Fortune 1981). Even in highly automated plants labour can still account for a high percentage of value added, because capital costs are spread over many units of product. Johnston (1982) estimates labour costs as a percentage of value added varying from 42 per cent for engines to 83 per cent for starter motors. Car producers are among the largest industrial employers and car factories are among the largest in the manufacturing industry. Wages and salaries are therefore a far from negligible item for car producers and it is only natural that in times of sharpening competition they search for possibilities to save on labour costs. Much of the labour that is performed in car factories is relatively simple and often repetitive ${ }^{3}$. Because of this, they have become major employers of unskilled and semi-skilled members of minorities (in the USA) and of 'guest workers' from marginal European and African countries (in France and West Germany). It is only one step further to move the factories southward to where the cheap labour force lives. This becomes attractive also as a means by which to reduce the social and political problems which the presence of large communities of foreign workers cause in the host countries, especially in times of growing unemployment and depressed demand for cars (Bhaskar 1980, p.170-71).

The production of cars depends on a large and diverse industrial environment which supplies the manufacturer with thousands of different parts. Car producers differ in their degree of vertical integration, but all are dependent on numerous outside suppliers, who are responsible for 40 to 60 per cent of the value of most cars. This makes the passenger car a less likely candidate for 'runaway production'. This need for an infrastructure, of course, is precisely why many developing countries have become interested in promoting a national car industry which they expect to stimulate a whole range of other manufacturing industries. By the early 1970s some Latin American countries had succeeded in acquiring a broad range of automotive industrial capable of producing at least some components. We shall discuss these capabilities more fully below. Here it is sufficient to note that a great many automotive parts could, in principle at least, be produced in some low-wage

${ }^{3}$ It is difficult to provide accurate data on the relative skill intensity of the automobile industry. Automobile workers have often succeeded in securing higher wage rates than workers in other branches of industry, but this cannot be interpreted to mean that higher skills are required in car manufacturing. Neither can formal levels of education be used as an immediate indicator of required skills. To take German Volkswagen workers as an example: in 197750.8 per cent of the wage eamers at VW did not have a complete vocational training. 2.2 per cent were in the process of getting one; 47 per cent did have one but many of them in fields that were totally unrelated to their present activities (Doleschal-Dombois 1982: 125). A study on the introduction of robots in the car industry notes that at the largest VW factory in Wolfsburg, two-thirds of 31,800 production workers perform repetitive tasks. Not all of these must be simple or unskilled, but very often the needed skills have been acquired inside the factory. About one-third of all VW production workers are employed in assembly activities (Mickler et al. 1981: 198, 223). 
Thus, all conditions for relocation of production seemed to be fulfilled. The only thing missing was an event or 'threat' to push the car multinationals into large-scale investment activities in developing low-wage countries. The 1970s, of course, produced plenty of pressures and threats.

\section{the oil crisis and the Japanese challenge}

Apart from a one-year downturn in the second half of the $1960 \mathrm{~s}$, the 1973 oil crisis inaugurated the first major crisis in the world car industry since the Second World War. World production of passenger cars fell for two years in a row $(1974,1975)$, and in Western Europe and North America the 1973 record production levels were not reached again, with the consequent emergence of a long-run over-capacity in these areas.

The rising price of petrol, which gave the oil crisis its name, made it more expensive to drive a car. Petrol prices rose quickly, first in 1974-75 and then again after the 'second oil crisis' in 1979-80. To some extent this was compensated for by rising wages and salaries, but during the second half of the 1970 s in particular, petrol prices were rising in real terms. The effects of this on car sales and car usage, however, were probably overshadowed by the effects of lower economic growth rates, increasing unemployment and, consequently, by growing uncertainty about future income and employment. This all served to emphasize the increasing maturity and even saturation of the market for passenger cars in the United States and large parts of Western Europe.

Slower growth and instability of demand lead to sharpening competition between suppliers. In a zero-growth market gains can only be made at the expense of the market shares of competitors. In this case, the situation was exacerbated by the appearance of a new supplier. European and American producers were confronted with a major export offensive by the Japanese car industry which started in the second half of the 1960s (Wells 1980, p.248-49). Japanese exports of passengers cars to the USA increased almost sixfold between 1970 and 1980 . Exports to Europe grew even faster, from e mere 100,000 in 1970 to over a million in 1980 , 75 per cent of which went to the EC countries, i.e. to the home countries of the European car industry.

What made the Japanese export offensive so extremely successful? The first thing that must be mentioned is their price. Japanese cars were relatively cheap, so much so that some observers in the early 1970 s were inclined to see the Japanese advantage almost exclusively in low wages (Wells 1980). By now, however, it has become clear that the Japanese car industry is characterized by better quality management, high levels of automation (i.e. high labour productivity) and good quality design. Above all, it must be recognized that the Japanese car industry had been specializing in exactly the type of car that proved to be the runner of the mid-1970s: small cars with high fuel economy. In that sense, the Japanese were just 'plain lucky' (Takeo Hosoya in Ott 1982, p.38). Whatever the cause of their 
success, the Japanese made price and cost considerations more important features of competition in the car industry than they had been in the previous decades. Wasn't this the final stimulant needed to expel passenger car production out of its traditional locations in Europe and North America? Relocation to low-wage countries only makes sense if labour productivity remains approximately the same in the process. Only then is it really meaningful to speak about 'low' wages. Productivity, at least in the car industry, is related strongly to the scale of operations. Here we encounter an additional problem for relocation, which has been discussed less than the requirements mentioned above. Experience in the traditional car-producing countries has shown that here are substantial economies of scale to be earned in the car industry up to a production of several hundred thousand (Bhaskar 1980, p.55). There are virtually no developing economies with markets of that size for passenger cars. The product cycle theory argues that at first a local industry is built up to cater for the local market, formerly the export market. Considering the size of these markets in the case of passenger cars, it is clear that any advantages in the way of low wages would then be much less than the economies of scale reaped in the home countries of the car industry. Only if factories of approximately 'world scale' were to be built, with much higher capacity than was needed for the local market, would low wages make a difference. The size of the operation and the ensuing heavy dependency on exports and related government attitudes would make a straightforward relocation of car production from a traditional location to a developing country a very risky undertaking. As we have seen, however, practice in other branches of industry had thrown up an alternative: world-wide sourcing, which came to be known in the auto industry as the 'world car strategy'.

The idea of a 'world car' became popular in the US auto industry as the consequences of the oil crisis came to be felt, and fuel economy became an important criterion in the purchase decisions of most car buyers. On the American market, in particular, this was cause for concern for the car manufacturers. During the post-war period, American car buyers had shown a decided preference for big, heavy cars with large and powerful engines. The car producers for their part had been all too willing to produce such cars, as bigger cars tend to be more profitable than smaller ones. Moreover, the predominance of big cars isolated the North American market from foreign competition. Even before 1973, however, this isolation came to an end with imports of mostly small cars, first from Europe and then from Japan, increasing from 5.1 per cent in 1963 to 15.45 per cent of the market in 1973 (Wilkins 1980, p.256). These changing preferences of American buyers were reinforced by legislation concerning the fuel efficiency of cars. The Energy Policy and Conservation Act of 1975 created mandatory standards for the average fuel consumption rate of cars that were sold by a firm in a given year. The threat of large fines forced firms to 'down-size' their larger models and to promote the sale of their smaller models. By the mid-1970s American producers were importing small cars from their own subsidiaries or from foreign manufacturers to comply with the fuel efficiency standards as well as to enlarge their product offering in the lower brackets of the market.

Successful imports into the USA, the increasing importance of fuel efficiency, 
'down-sizing' and also the introduction of a $55 \mathrm{mph}$ speed limit brought the structure of demand in the US car market much more into line with that in other parts of the world. American producers, who were already producing Europeansized cars in Europe, now saw increasing possibilities for the development of a passenger car which could be sold all over the world: a 'world car'. In a sense, there had been 'world cars' before. The Model-T Ford and the VW-Beetle had been sold all over the world. In the $1970 \mathrm{~s}$, however, due to the international operations of the big car manufacturers, the concept of a world car took on new meaning. They would not only be sold, but also manufactured, all over the world. Parts would be produced on a world-scale at the lowest cost location and would then be shipped for assembly or further processing to other places and countries. Of course, the model would need to be adapted to local regulations and preferences, but it would basically be the same standardized car, with development costs spread out over millions of vehicles sold and economies of scale reaped wherever possible (Lall 1980, p.810; Goldschmidt 1980, p.55). This strategy would make it possible to utilize the advantages of producing on a world-scale in lowwage countries, without the disadvantages of becoming dependent on the export and industrial policies of a single developing country. The viability of the strategy would depend on the willingness of developing countries to engage in an exportoriented development policy. It would mean that new national car industries would not come into existence. Instead, countries would specialize in the production of specific parts, exporting most of them. Trade in parts would increase and national producers would become subservient to the global planning of multinational car manufacturers.

Reviewing what has been said in this section, one would expect a process of relocation in the passenger car industry to have got under way in the 1970 s. If this were true, it would have to show in: (a) increasing production of cars and automotive components by subsidiaries of car multinationals in developing countries; (b) increasing exports of cars and/or automotive components from developing countries to the developed countries.

In the following section we shall review some data on production and trade in the 1970 s. First, we shall look at the pre-crisis record production year, 1973, and sketch the development of the international spread of car production up to that point. Then we shall examine the course of events since then.

\subsection{Production and trade of automotive products in the $1970 \mathrm{~s}$}

before the crisis: the situation in 1973

In 197390 per cent of the world production of cars took place in Europe (OECD), North America and Japan. Another 5 per cent was produced in the Soviet Union and Eastern Europe (CMEA). Two-thirds of the remaining 5 per cent of works production took place in three Latin American countries: Argentina, Brazil and Mexico. In Asia, only India showed a minimal of production of passenger cars. Australia, mainly producing and assembling for its own market, and Yugoslavia 
complete the list ${ }^{4}$.

In Western Europe, Spain is growing in importance. The share of the four traditional car producing countries (France, Italy, West Germany and the United Kingdom) has declined quite strongly since the mid-1960s. The Spanish car industry is a direct result of purposive government policy. The Spanish state actively promoted investment behind a high tariff-wall for built -up cars. Foreign producers were invited to participate in joint ventures with Spanish firms. By regulations prescribing an increasing local content for the cars, assembly activities were then gradually turned into a Spanish-based car industry. Low wages and the suppression of strikes were, of course, an additional attraction that the Franco regime could offer foreign investors. In 1973 eight multinational car manufacturers and their local partners produced 96 per cent of the Spanish car production (cars and trucks) (Maxcy 1981, p.127). Almost 20 per cent of this was exported. The internal market, however, was still very much protected and the number of producers too large to face the competition which would result, for instance, after Spain joined the EC. Only by production on a larger scale and/or the import of cheap parts could the Spanish industry be made competitive on the world market. Therefore, in 1972 the Spanish government lowered the local content rules from 70 to 50 per cent on condition that exports would increase. Exports were also encouraged by lower taxes and credits. Among other things this led to important investments by Ford in Spain in the mid-1970s.

Outside the OECD, two groupings of car-producing countries can be distinguished: on the one hand the countries of Eastern Europe and the Soviet Union, organized in the Council for Mutual Economic Aid (CMEA), and Yugoslavia; on the other hand the developing countries in South America and Asia. Although economic conditions are quite different between these two groupings, there is an interesting similarity in the development of their car industries: in the East as in the South the multinational car makers of the Western world have played an important part.

The production of passenger cars in Eastern Europe and the Soviet Union has been growing at a respectable rate since the war. Several West European producers made an important contribution to that process. American and Japanese firms were (and are) practically absent in Eastern Europe. The main purpose of car production in the CMEA countries is to provide for the domestic market, but in the first half of the 1970s exports of cars and parts to Western Europe also began to grow. Some of these exports were part of the agreements on technical assistance and were really payments 'in kind'.

\footnotetext{
${ }^{4} \mathrm{~A}$ car is counted as produced in a country if more than 50 per cent of its value consists of parts that have been produced in that country, which is not always an easy thing to calculate. It is possible, therefore, that in figures for countries like Argentina, Brazil or Mexico, some cars that have been assembled from imported parts have been counted as produced in those countries. On the other hand, in figures for the traditional producing areas, cars that have been produced in a ckd form and shipped in a box for assembly elsewhere, have been counted as produced cars. In the end, if trade in parts would really become a major element in the international set-up of car production, the count of cars produced in specific countries would become increasingly meaningless.
} 
The focal point of car production in the developing countries lies in South America. Outside that continent only India possessed a passenger car industry in 1973. The Indian industry is a purely domestic affair, whereas in South America it is dominated by the big multinational car makers. These differences follow directly from the divergent policies of the national governments concerned. The Indian government attached low priority to the production of passenger cars and did not encourage direct investment by foreign firms. Local content of Indian vehicles lies above 95 per cent but the technology used is outdated.

In South America, US car manufacturers were active even before the Second World War. Until the end of the 1950s their activities remained limited to assembly of more or less 'completely knocked down' (ckd) imports. This situation changed due to pressure enforced by the national governments involved. Brazil, Mexico and Argentina developed ambitious industrialization plans, in which the production of cars took an important place. Foreign firms were invited to invest in production facilities on condition that they would gradually increase the local content of the cars produced. In exchange, the governments promised protection and tax allowances. Motivated mainly by fear of losing potentially important future markets, almost all large car producers participated in the government programmes of one or more of these countries. Without these programmes such investments would in all likelihood not have taken place, local production costs being much higher than in home countries due to the disadvantages of small scale and deficiencies in the infrastructure (Vacano 1979, p.155).

Although there were some differences in the legislation of the three countries, by 1973 the results were very much alike: local producers had been pushed out of the market and what remained were subsidiaries of the large multinationals, all producing far below optimum scale. Tariff walls kept car prices above world market level. The high costs of inefficient production made export possibilities slim. Moreover, the growth of a national car industry had not really brought the benefits that these countries had expected, especially not in the field of the balance of payments. Some of the needed infrastructure for the production of parts had come into existence, but the imports of some parts remained necessary and a steady stream of dividends and royalties went out of the countries. In the early 1970s, therefore, the three countries changed their policies in order to promote exports. Subsidies and additional tax allowances for exporters were combined with lower local content requirements, on condition that the extra imports would be compensated by extra exports. These measures would make it possible, in principle at least, to integrate the subsidiaries into the global network of production of their respective parent companies.

We complete our review of the year 1973 with a look at the trade flows. Imports of automotive products by OECD countries from non-OECD sources were quite small. CMEA and Yugoslavia together accounted for over 50 per cent of these imports; in the case of Western Europe even for almost 90 per cent. Imports of passenger cars from developing countries into the OECD were non-existent. The inflow of 'bodies and parts' from developing countries into the OECD area was a little larger, but its value was still less than 1 per cent of total imports of such items 
by the OECD. Most of these parts came from the car-producing countries in Latin America; more than half, worth $\$ 43.4$ million, from Mexico.

Spain, on the other hand, exported 153 million dollars-worth of passenger cars in 1973 , all of them to Western Europe. Exports of parts were valued at \$54 million. Exports from Spain were thus quite sizeable even before the government started a more vigorous export promotion policy.

Summarizing the period up to 1973 , it seems that at least some of the investment in Spain can be considered as a cost-cutting strategy of the European manufacturers combined, of course, with the desire to participate in the Spanish car market. Activities in other developing economies before 1973 seem to have been motivated mainly by the wish to retain a foothold in large markets, and prompted by protective government policies rather than by some cost-cutting strategy on the part of the firms. Even in the case of Mexico, close to the US market (comparable to Spain in Europe), where one might expect investment with the express purpose to export the products to the USA, this does not seem to have happened (Bennett \& Sharpe 1979). The activities of car multinationals in Eastern Europe were also called forth by government action and not by a desire to relocate production to these countries.

\section{production and trade after 1973}

After 1973 neither Western Europe nor North America could maintain their shares in the world production of passenger cars. The share of USA/Canada went down by 12 percentage points between 1973 and 1980. Most of the gains went to Japan, but the shares of Eastern Europe and of the developing countries also increased appreciably over the same period, each reaching about 7 per cent in 1980 . within Western Europe, whose share went down from 39 per cent in 1973 to 36 per cent in 1980, there was a further movement away from the four traditional carproducing countries. In 1980, Spain produced 10 per cent of all passenger cars in Western Europe. In South America, Brazilian car production reached almost a million units in 1980. Production in Mexico also grew slowly throughout the 1970s. In Argentina the industry suffered from the general economic problems of the country and the production of cars fluctuated accordingly. General Motors closed its plants in Argentina in 1978. Chrysler sold its activities to Volkswagen the next year and Peugeot withdrew in 1981. In 1980 European firms accounted for twothirds of the production of cars in these three countries.

Another developing country is now counted among the carproducing countries: South Korea, where Hyundai Motors, a subsidiary of the largest industrial corporation of the country, dominates the market. Hyundai started as an assembler of ckd kits from Ford UK but now produces its own product, the Pony. The Pony is an Italian design, using parts that originated in many countries. All parts are produced in Korea under licence, local content reaching a level of over 90 per cent. The car is exported all over the world, but mostly to other developing countries. Sales have not expanded as rapidly as had been hoped, however, and neither has the Korean domestic market. Hyundai Motors recently sold 10 per cent 
of its equity to Mitsubishi and now tries to realize its ambitious expansion plans with technical aid of the Japanese firm (Kraar 1983).

Exports of cars by Spain increased rapidly throughout the 1970 s. In 1980470,000 passenger cars were exported, about 45 percent of which went to the big carproducing countries in Western Europe. This has clearly been a case of production relocation. Naturally, most Spanish exports of parts, although much less important than exports of cars, also go to the car-producing countries, not only in Europe but also in the USA (for this and the following, see Table 4.1).

Although trade within the OECD area has been growing rapidly, the share of imports from non-OECD countries has also been increasing although it is still on a very low level. Not quite according to our expectations, imports of cars have grown faster than imports of parts. Imports of cars from non-OECD countries increased their share in total imports of cars from 0.3 in 1970 to 1.3 per cent in 1980. The share of non-OECD parts in total imports of parts rose from 0.7 in 1970 to 2.8 per cent in 1980 . In the imports of passenger cars Eastern Europe and the Soviet Union clearly dominate but they lost some ground in the half of the 1970s, mainly to South America. Yugoslavia's share in OECD car imports also increased slowly throughout that decade. By 1980 the CMEA countries and Yugoslavia together accounted for 76 per cent of car imports from non-OECD countries into the OECD. Since car imports from CMEA countries come from independent producers competing on the European market, this is not a case of relocation as we have defined it, even though the Western car multinationals have been involved in building up these producers. An exception to this is the 1979 agreement between Poland and Fiat, which arranged for the production and exports to Western Europe of the Fiat 126. production of which was to be phased out in Italy.

Imports of parts from CMEA countries have been less important. Yugoslavia, on the contrary, which is tied to the car multinationals through numerous licence agreements and joint ventures, exported as much as all CMEA countries together. Brazil and Mexico were the fastest growing exporters of parts, accounting for almost 60 per cent of non-OECD imports by 1980 . In the second half of the 1970 s, however, other developing countries also increased their exports of automotive parts to the OECD.

Imports of cars and parts have not been spread evenly over the three main areas within the OECD (Table 4.2). OECD-Europe imported 96 per cent of all cars imported from non-OECD sources by the OECD in 1980. Moreover, the share of cars in automotive imports from non-OECD countries increased for all four big carproducing countries in Europe throughout the 1970 s, which does not indicate a world-car strategy. Rather, it seems that the complete production of some models has been shifted to South America (but much less important than to Spain). Sourcing of parts seems to have become relatively less important. On the other hand, the USA was the most important importer of parts from non-OECD countries, mostly from South America. This seems to indicate that American firms are following a world-car strategy, but it should be added that these imports were less than 7 per cent of total imports of parts in 1980. 
Table 4.1

Imports of Cars and Parts to OECD from Non-OECD Countries, and from Spain 19701980 (millions of dollars)

\begin{tabular}{|c|c|c|c|}
\hline Cars from: & 1970 & 1975 & 1980 \\
\hline World & $8,755.5$ & $21,039.5$ & $50,504.2$ \\
\hline Spain & 17.8 & 216.8 & $1,698.9$ \\
\hline Non-OECD & 24.2 & 179.2 & 651.7 \\
\hline Comecon-Eur. & 21.3 & 162.7 & 461.6 \\
\hline Yugoslavia & 0.6 & 7.9 & 33.6 \\
\hline S. America & 0.3 & 5.2 & 109.7 \\
\hline Brazil & 0.1 & 3.2 & 48.6 \\
\hline Mexico & 0.1 & 1.8 & 42.4 \\
\hline Argentina & 0.1 & 0.1 & .15 .5 \\
\hline South Africa & 0.1 & 0.9 & 14.4 \\
\hline South Korea & n.a. & n.a. & 18.4 \\
\hline Parts from: & 1970 & 1975 & 1980 \\
\hline World & $4,675.6$ & $12,214.0$ & $25,379.0$ \\
\hline Spain & 16.9 & 98.7 & 349.7 \\
\hline Non-OECD & 34.3 & 219.1 & 700.9 \\
\hline Comecon-Eur. & 9.8 & 36.7 & 101.5 \\
\hline Yugoslavia & 7.6 & 27.2 & 90.0 \\
\hline S. America & 11.9 & 139.9 & 413.9 \\
\hline Brazil & 1.5 & 31.4 & 180.0 \\
\hline Mexico & 9.9 & 99.8 & 206.4 \\
\hline Argentina & 0.4 & 1.9 & 72 \\
\hline South Africa & 1.4 & 2.7 & 8.8 \\
\hline India & 0.1 & 1.1 & 6.3 \\
\hline Philippines & - & 2.4 & 26.8 \\
\hline Hong Kong & 0.3 & 1.9 & 3.6 \\
\hline Taiwan & 0.1 & 1.7 & 15.0 \\
\hline South Korea & - & - & 5.7 \\
\hline
\end{tabular}

Source: OECD Statistics of Foreign Trade, SITC (rev. 1), 7321, 7328, (1970, 1975); SITC (rev. 2), 781, 784 (1980). 
Table 42

Imports of Cars and Parts to OECD from Non-OECD Countries, Specified for Main Areas within OECD 1980 (millions of dollars)

\begin{tabular}{|c|c|c|c|c|c|}
\hline Cars to: & OECD & USA & Japan & OECD.Eur & $\begin{array}{c}\text { Fr./FRG/ } \\
\text { It./UK }\end{array}$ \\
\hline \multicolumn{6}{|l|}{ from: } \\
\hline non-OECD & 651.7 & 11.9 & 1.0 & 622.8 & 434.1 \\
\hline CMEA & 461.6 & 3.6 & - & 441.8 & 280.8 \\
\hline Yugoslavia & 33.6 & - & - & 33.6 & 25.6 \\
\hline S. America & 109.7 & 0.3 & 0.7 & 108.7 & 102.7 \\
\hline Mexico & 42.4 & - & - & 42.4 & $39.3^{*}$ \\
\hline Brazil & 48.6 & 0.2 & 0.7 & 47.7 & $45.1^{*}$ \\
\hline Argentina & 15.5 & - & - & 15.5 & $15.4^{*}$ \\
\hline South Africa & 14.4 & - & - & 14.4 & 14.1 \\
\hline South Korea & 18.4 & 7.9 & - & 10.5 & - \\
\hline \multicolumn{6}{|l|}{ Parts from: } \\
\hline non-OECD & 700.9 & 379.6 & 9.4 & 283.7 & 224.0 \\
\hline CMEA & 101.5 & 32.3 & - & 65.5 & 37.9 \\
\hline Yugoslavia & 90.0 & 2.3 & - & 87.7 & 82.0 \\
\hline S. America & 413.9 & 315.0 & 0.5 & 89.7 & 74.3 \\
\hline Mexico & 206.4 & 184.1 & 0.4 & 16.5 & 16.3 \\
\hline Brazil & 180.0 & 115.2 & - & 61.8 & 53.1 \\
\hline Argentina & 7.2 & 0.4 & - & 6.7 & 1.0 \\
\hline South Africa & 8.8 & 3.2 & - & 4.2 & 3.7 \\
\hline Philippines & 26.8 & 0.6 & 6.2 & 142 & 8.8 \\
\hline Taiwan & 15.0 & 10.9 & 0.5 & 1.9 & 1.1 \\
\hline India & 6.3 & 2.1 & - & 3.2 & 2.1 \\
\hline South Korea & 5.7 & 2.2 & 1.9 & 1.0 & 0.4 \\
\hline
\end{tabular}

"Mexican car exports only to FRG; Brazilian and Argentinian only to Italy.

Source: OEC.D Statistics of Foreign Trade, SITC (rev. 2), 781, 784.

Not all parts for motor vehicles are included in the statistics we have referred to so far. Two more items might be important for the question of relocation: internal combustion engines and automotive electrical equipment. On the basis of the limited data available, it can be estimated that imports of automotive electrical equipment from developing countries grew from 0.7 in 1972 to between 7 and 10 per cent of total OECD imports in 1980 (Table 4.3). Thus, imports of electrica! equipment seem to have grown much faster than imports of cars and parts from the developing countries. As most car manufacturers do not produce this equipment themselves, the imports probably come from independent local firms or subsidiaries of one of the large parts suppliers that have also turned multinational. 
Table 4.3

Imports to OECD/Exports to World of Automotive Electrical Equipment (millions of dollars)

\begin{tabular}{|c|c|c|c|c|c|c|}
\hline & \multicolumn{2}{|c|}{ Imports to OECD } & \multicolumn{4}{|c|}{ Exports to world market economy } \\
\hline & 1972 & 1975 & 1976 & 1974 & 1979 & 1980 \\
\hline \multicolumn{7}{|l|}{ From: } \\
\hline $\begin{array}{l}\text { World (1972, 75)/Market } \\
\text { economies }(76-80)\end{array}$ & 596.9 & 949.3 & $1,532.0$ & $2,219.0$ & $2,544.6$ & $2,781.2$ \\
\hline $\begin{array}{l}\text { OECD }(1972,75) / \text { Developed } \\
\text { market economies }(76-80)\end{array}$ & 590.3 & 911.8 & $1,480.2$ & $2,114.6$ & $2,428.5$ & $2,682.1$ \\
\hline Comecon & 2.3 & 5.7 & n.a. & n.a. & n.a. & n.a. \\
\hline Developing economies & 3.9 & 31.5 & 51.7 & 104.4 & $116.1^{*}$ & \\
\hline $\begin{array}{l}\text { American developing } \\
\text { economies }\end{array}$ & 1.1 & 21.3 & 32.2 & 69.4 & $61.7^{*}$ & \\
\hline Brazil & 0.8 & 16.9 & 28.1 & 55.4 & 45.6 & \\
\hline Mexico & 0.1 & 2.5 & 0.7 & 1.9 & $1.8^{*}$ & \\
\hline Argentina & - & - & 1.8 & 1.8 & $2.2^{*}$ & \\
\hline $\begin{array}{l}\text { Far East }(1972,75) / \text { Asian } \\
\text { developing economies }(76-80)\end{array}$ & 1.7 & 4.6 & 19.2 & 33.3 & 52.4 & $44.6^{*}$ \\
\hline Singapore & $\cdot$ & 1.2 & 6.6 & 16.3 & 12.5 & 18.1 \\
\hline Hong Kong & 1.3 & 1.8 & 3.5 & 7.2 & 13.0 & 17.1 \\
\hline Korea & 0.1 & 0.1 & 2.5 & 2.5 & 1.6 & 2.0 \\
\hline India & 0.2 & 0.3 & 1.3 & 2.0 & $4.8^{*}$ & \\
\hline
\end{tabular}

\section{*Preliminary}

Sources: 1972, 1975, OECD: Trade by Commodities (SITC 7294 (rev. 1)); 1976-1980: UN Yearbook of International Trade Statistics, 1980 (SITC 7783 (rev. 2)). 
Table 4.4

OECD Imports of Internal Combustion Engines (millions of dollars)

\begin{tabular}{lrcr}
\hline From: & 1972 & 1976 & 1980 \\
\hline & & & \\
World & $3,136.8$ & $5,368.8$ & $10,204.3$ \\
Non-OECD & 43.8 & 287.9 & 512.8 \\
Comecon Europe & 8.1 & 74.8 & 59.7 \\
Developing countries & 34.4 & 211.9 & n.a. \\
Non-OECD America & 27.3 & 171.2 & 360.8 \\
Brazil & 6.1 & 87.9 & 278.6 \\
Mexico & 20.5 & 82.3 & 75.8 \\
\hline
\end{tabular}

Sources: OECD Trade by Commodities, Series B, SITC (rev.1), 7115 (1972,1976); OECD Trade by Commodities, Series C, (rev. 2), 713 (1980)

Engines are, of course, a more important and heavier part of motor vehicles than the electrical equipment. To set up facilities for the production of engines requires major investments, and the minimum efficient scale of production for individual engine types is usually estimated to be at least 300,000 units per year. Available data are again limited, but it can be estimated that in 1972 imports of engines from non-OECD countries amounted to approximately 1.5 per cent of total imports from the world into the OECD (Table 4.4). By 1980 this share had increased to about 5 per cent, which means that imports of engines were more important than imports of other parts. In 1980, South America had a 70 per cent share in this trade and the CMEA countries 12 per cent. Imports of engines from Spain into the other OECD countries grew even faster than those from non-OECD countries. Almost all went to the four big carproducing countries in Western Europe.

The evidence referred to above indicates that: (a) there is no sign of relocation in the Japanese industry; (b) inside Europe the process of relocation of the car industry to Spain continues; (c) licencees in Eastern Europe are sometimes used as parts suppliers by European manufacturers, and, in the case of Fiat, also as suppliers of cars, but they also appear on the West European market with competitive exports; (d) relocation to developing countries is quite limited. The US car makers import some parts and engines, mainly from Brazil and Mexico. European manufacturers buy parts and engines in South America, but also import built-up cars. Their imports show less of a world-wide sourcing pattern than those of the USA, except for trade in engines.

\subsection{Alternative strategies for the automotive firms}

On the basis of the evidence surveyed above, it is difficult to conclude that the passenger car industry is relocating its production to low-wage, developing countries. The American industry increasingly imports parts, but mostly from other 
OECD countries. In Europe there has clearly been relocation of production to Spain - but then Spain is itself a member of the OECD and expected to join the EC soon. It already has preferential tariff access to the EC market. The level of imports from non-OECD countries into the traditional car-producing countries is still very low, and although these imports have been increasing since the oil crisis, their rate of growth has not been as high as might have been expected by those who gave the textile industry as an example.

Over the last five to ten years, moreover, European and US car manufacturers have undertaken very large investment programmes. Most of this investment was made in the home countries of the firms or in other developed countries, with only a small fraction of total investment going to developing countries (Cohen 1982; Maxcy 1981). In terms of our theoretical framework we have to conclude that either maturity in the car industry does not lead to relocation activities, or that our observations concerning the maturity of the car industry were premature. We shall now look into both of these possibilities, starting with the latter.

\section{maturity and rejuvenation}

There is no reason to retreat from our earlier conclusion that the car industry was a mature industry in the early 1970 s. It could be objected that the product was less standardized in Europe than it was in the US (Committee on Technology 1982, p.45). Because of its varied national origins the European industry had developed quite different types of passenger cars, and product innovation had always remained a more important aspect of competition. Still, technological change had become incremental and in the late 1960 s a host of mergers and cooperative agreements between European firms underlined the maturity of the industry (Fennema 1974). The question is not whether the car industry was mature or not around 1970 but whether it remained so in the following decade.

Our expectations for relocation of the industry were based on the need to lower production costs in a situation of increased price competition. An alternative for a move to low-wage areas might be a further automation of the production process as well as other measures to improve productivity. Yet another alternative is to change the character of competition again, with emphasis on quality instead of price. By adding innovative features to the product, it can be made attractive to the consumer, even if it is higher-priced. By 'rejuvenating' the product it can be prevented from entering the last 'runaway' phase of its life cycle (Hayes-Abernathy 1980). Can the absence of relocation in the car industry during the 1970 s be explained by a renewed emphasis on process and product innovation?

There is much to be said for such an explanation. Several factors have contributed to a general speed up of technological change in the automobile industry. Naturally, the European and American producers studied the production system of their new competitors in Japan intensively. Japanese management methods were copied wherever this seemed to promise an increase in productivity. Japanese emphasis on automation found its counterpart in extensive plans for robotization in America and Europe. Automation of production often requires a change in the 
product: and changes in the product also require changes in the production process. There have been many such changes. Increasing pressure by governments and consumers to provide for more safety and lower fuel consumption encouraged research and development in the car industry. New materials were introduced to reduce the weight of cars (aluminium, plastics) and to improve the energy efficiency of engines (ceramics). Consequently, new production techniques were introduced (the use of adhesives, new coating methods). Electronic technology is applied to control of engine and drive train, to suspension and steering system. Components suppliers have played an important role in the process. Many more applications of micro-electronic technology are expected in the coming decade. It is very difficult indeed to maintain that technological change in the automobile industry is still incremental under these circumstances. On the contrary, all changes added together constitute a veritable revolution in the industry. Management is confronted with the difficult task of combining all these innovations into a recognizable and reliable product, timing the sequence and tempo of their introductions, adapting the production process to avoid unnecessary costs and to improve productivity wherever possible. Instead of maturity, we wee increasing diversity: 'it appears that the development of product technology in the 1970s constitutes a sharp reversal of the pattern of technical change that dominated from 1900 to 1950 . The earlier era was dominated by standardization: first in engines, then the chassis, diversity in engine configuration, control systems, drive trains and materials' (Committee on Technology 1982, p.7). It is understandable that management shows little inclination to engage in production in developing countries, because this would only add new problems (training personnel, building up suppliers) to the existing ones, the correct solution of which promises more gains than can be expected from production in low-wage countries.

Jones (1981) distinguishes three dimensions in the competitive environment of the car industry: competition in process technology (productivity), in product technology and in 'international positioning' (i.e. optimal production and marketing locations). He shows that the three major car-producing areas differ in relative strength on these dimensions. Whereas Japan is strongest in process technology, the Europeans seem to have an advantage in product technology and the American firms are best positioned for worldwide sourcing and selling operations. In times of sharpening competition firms will try to improve on all three dimensions, but one might expect that they would build their competitive strategy on their strongest asset. And indeed, Japanese firms are hardly engaged in world-wide sourcing, trusting instead to their low-cost, highly automated production processes, and trying to improve on the product technology. European firms did engage in some sourcing from low-wage countries, but their main strength remained in product technology. The many smaller European producers of high-quality luxury cars play an important role here. In American industry, the concept of the world car was developed, but apparently it did not find as much use as might have been expected. The reason is very likely that American industry was producing the wrong kind of passenger car: large 'gas-guzzling' vehicles which couldn't satisfy the new standards of the 1970s. It would not make sense to go through the complexities of production in developing countries if the resulting product could not be sold. American industry was practically forced to put all available energy into the design, 
construction and production of smaller cars. In other words, it also had to engage in qualitative competition.

Thus, in reaction to increasing price competition in the early 1970s, the industry went back to the drawing boards, reversing trends towards standardization and maturity, rejuvenating its product. This raises questions concerning the concept of maturity. Can an industry by its own actions determine the degree of maturity of its product? Can it simply reverse earlier trends? Then, of course, the predictions of the product cycle theory are weakened. We would suggest that this is not the case. Special circumstances influenced the rejuvenation of the car industry which were not controlled by the industry itself. On the one hand, it was confronted by changes in consumer demand as well as by government regulations concerning safety and fuel consumption. On the other hand, a technical revolution outside the car industry, the micro-electronics revolution, made possible a whole range of new components and performance features in the passenger car. Increasing competitive pressures probably forced the industry into a faster adoption of the new technologies than otherwise would have been the case. Thus, it can quite plausible be argued that relocation of the car industry did not occur, due to extraordinary circumstances and outside influences which temporarily halted and even reversed the process of maturing the industry's product. It should be noted too, that government has influenced this process through regulations and technology policies which encourage the development and use of new technologies.

\section{relocation and government policies}

Can we then safely predict that the car industry, after the temporary rejuvenation of its product, will start to move to low-wage countries? After all, in other respects the car industry gas not become less mature at all. The market in developed countries still has a very high replacement component and concentration in the industry has remained high. The experience of the 1970s suggests that we should be cautious in our predictions. Looking at labour costs and production technology only, even now many of the smaller components of medium technology and high labour content could probably be produced more cheaply in developing countries (Johnston 1982). But other costs and benefits have to be included in the calculations. This becomes clear when we remember that engines were quite important in exports by non-OECD countries. Engines are a major sub-assembly with high value, for which transportation costs are relatively unimportant, production is highly automated and labour content relatively low. It does not seem to be a very suitable product for developing countries.In such cases, the decision to locate a new plant in a foreign country will depend less on labour or transportation costs and more on other advantages offered by the country involved (cheap financing, preferential access to the market, freedom of taxation, subsidies). For instance, 'in the case of Fords's recent decision to locate an engine plant in Mexico without the government policies that reduced the overall cost of building the plant, there was little difference between producing in Japan, the US or Mexico' (Cohen 1982, p.4). Furthermore, precisely because it is highly automated and represents a major sub-assembly, the production of engines is probably quite suitable to fulfil local content requirements in an economic way - at least if export 
of surplus production is possible.

As such, there is nothing unusual about the fact that government policies in the field of finance and trade enter into the cost and risk calculations of firms in general and of firms in the car industry in particular. On the contrary, 'from the earliest days of the world industry, tariffs, taxes, quotas, and regulations have been used in one form or another to influence the location of production and the volume of trade' (Committee on Technology 1982, p.56). What is unusual is that in the late 1970 s some of the policies that were known almost only from the developing countries began to appear also in the developed countries. Firm failures and growing unemployment brought a revival of protectionist sentiment. Japanese exports of cars to Western Europe and the USA were limited by quota systems or 'voluntary' restraint. In the US Congress legislation has even been proposed to introduce local content requirements (The Economist, 1982). In addition, there were many 'non-tariff barriers' to relocation: premiums for investment in economically weak regions, government loan guarantees, government participation in threatened firms, etc. The point is that over the last decade a changing political environment in Western countries has made it prudent and economically acceptable for a firm to keep the bulk of productive activities close to the markets where the products have to be sold, i.e. within the OECD area. Thus, it can also plausibly be argued that car makers in Europe and North America preferred to invest in their home countries rather than in developing countries because of the real and potential intervention by their own governments.

This does not mean that there will be no investment in developing countries; only that this will be tuned to the level of demand there. Thus, although relocation in the sense in which it has been defined in this paper does not seem likely to become very important in, say, the next decade, the export markets of the traditional producer countries uutside the OECD will increasingly be served by subsidiaries of the car multinationals in those countries.

Some observers of the industry have suggested that the multinational car producers are now organizing their production on a regional basis (Maxcy 1981, p.144ff.). Ford, for instance, opened up a new car body stamping plant in the Philippines in 1976 , with a capacity of 70,000 bodies per year. At the same time, the capacity of the engine plant in Taiwan was enlarged to 70,000 per year. In New Zealand Ford has a transmission plant. Most of the products of these plants go to assembly operation in the same area. In this way the automotive balance of payments can remain roughly in balance for the countries involved and production is on a more efficient scale than would be possible for each country separately. The scale of operations is still far below optimum size, of course; a regional approach makes sense only if the region combines liberalized trade among its members with a protective tariff wall on the outside. Indeed, this might very well be the outcome of the political-economic process described above: a regionalization of the world auto industry with different combinations of multinational car producers dominating in each region, and cost differences between each region smoothed out by tariff walls and other political and economic obstacles. It would be like 'downsizing' the world-car strategy. 
In the case of the passenger car industry, at least the economic crisis and the concomitant sharpening of competition have not appreciably increased the speed of relocation to developing countries, although this might have been expected on the basis of most literature on the issue.

The competitive process in the car industry tends to produce two divergent tendencies: on the one hand world-wide sourcing and investment in low-wage developing countries; on the other hand investment in advanced process and product technology, mainly in the traditional car-producing areas. The actual outcome of this process, i.e. the degree of relocation of the car industry, depends on the speed of technical change and on (expectations concerning) government policies of the developing countries, but even more so of the developed nations. As long as the latter suffer from unemployment and/or deterioration of their balance of payments, it can be expected that government policies will throw up barriers to relocation, directly by protectionist measures and investment subsidies, and indirectly by policies promoting the application of new technologies.

Did the extensive literature on foreign investment and multinational enterprise not take account of the importance of the political environment for international trade and investment? Of course it did and yet in a way it did not. An extensive literature on the location of foreign investment pointed out that most industry sources would emphasize markets and not low wages as the most important consideration in the decision-making process. It was clear that tariff barriers were important factors guiding the stream of international direct investment. Still, it can be said that the literature neglected the importance of the political factors because in effect they pointed in the same direction as economic theory (but see Balassa 1979). The results of the forming of the EEC and of the introduction of tariffs and local content rules by the governments of developing countries only encouraged investment activities that were predicted on strictly economic grounds by the theories of the multinational enterprise, the product life cycle, or the new international division of labour.

The common background to all these theories was the assumption of economic growth and continuing innovative activities in the developed growth and innovative activities in the developed economies that would result in high employment levels and government policies favourable to trade and international investment. Now that economic growth is low or negative, unemployment high and innovative activities have not (yet) resulted in the growth of sufficient employment-generating industries, the political signals no longer point in the same direction as economic theory. Whether political forces in the developed countries can actually stop the economic forces pushing for relocation of the industry - and whether they really want to do that - remains to be seen. Predictions to that effect can only be made by a theory which incorporates more fully the working of the political process in the developed economies. 



\title{
5. Teamwork in the West German car industry and the quality of work ${ }^{1}$
}

\author{
5.1 Introduction \\ 5.2 New competition and new technologies: a double challenge \\ 5.3 The teamwork approach \\ 5.4 Consequences for the organisation and for the workers \\ 5.5 Environmental influences on the quality of teamwork
}

\subsection{Introduction}

Teamwork is a controversial topic and a source of many conflicts in the international car industry these days. In the US the automobile workers union UAW is very much divided on the issue. Whereas some of its leading officials favour teamwork as a future-oriented concept for the car industry, others feel that teamwork will have deleterious effects on worker solidarity. In March 1987 GM was forced by a strike in its Pontiac Truck and Bus complex to restore job classification, which had previously been eliminated by team methods of production. In the traditional system each worker has a specific job and uses seniority rights to change jobs. The team concepts provides for wider job descriptions and for job rotation. Apparently, workers couldn't be convinced here that seniority rights could be protected, or that an equivalent way of providing job security and promotion rights could be provided (Automotive News 1987). In GM's Bedford plant in the UK a similar conflict is under way (Financial Times 1987). In the other European car producing countries conflicts haven't reached these proportions (yet). Car manufacturers have been fairly slow in introducing team concepts here and besides that, in most countries workers'rights are not so strongly based on seniority and strict job classifications. Nevertheless in Europe too, team concepts have made their appearance and have required reactions by the unions. In september 1986 Hans Mayr at that time first chairman of the German Metal Workers Union IG Metall and President of the International Metal Workers Federation, called for the unions to 'participate offensively in the new group structures which may offer an opportunity for using new technologies actively in support of the workers.' (Mayr 1986, p.4). Mayr speaks of 'realistic steps away from the exaggerated division of labour of the past toward production structures

${ }^{1}$ Published in Wout Buitelaar (ed.) (1988), Technology and Work Labour Studies in England, Germany and the Netherlands, Avebury: Aldershot, etc., pp. 165-181. This chapter is based on research carried out within the project on 'risks and chances for the workers of the present restructuring in the automobile industry' at the Wissenschaftszentrum Berlin für Sozialforschung (WZB). Unless noted differently, quotes and figures are derived from project materials. 
Team concepts have been controversial in management circles too. Quite often especially middle and lower management are vehemently opposed to team concepts and actually a much larger stumbling-block than the workers on the shop floor. The motives for this opposition are mixed. Some see their power diminish as some of their decisions are taken over by production teams. Others see the real problems of teamwork and doubt that the rewards will be worth the costs (financial, time and effort) of a complete re-organisation of work (Saporito 1986; Lawler 1986). Notwithstanding all the opposition, team concepts are being introduced everywhere with strong support of higher management. That indeed is the interesting new phenomenon about teamwork in the second half of 1980's. 15 years ago teamwork was introduced in the car industry by way of experiment, in projects aimed at improving the quality of work. After a series of strikes and conflicts in the late sixties, the early seventies saw a worldwide revival of interest in quality of working life issues (Auer 1983; Cherry 1982; Guest 1979). In those days probably most managers were inclined to view such projects as costly undertakings, maybe necessary to appease workers, but not desirable by themselves. In fact, in West Germany several such 'humanization projects' could only be carried out because the government provided for substantial financial support (Dankbaar 1986; Volkswagenwerk AG et al. 1980). Proponents of the team concepts pointed out that quite often productivity was higher in the new set up and production costs lower, but for a long time such views remained the exception (Gyllenhammar 1977). Things have changed, however, since the early eighties. Team concepts have now become a widely accepted building block of management's modernisation strategies. Since 1975 almost all of the major car manufacturers in the United States and Western Europe went through a period of crisis and heavy losses. All of them came out of those crises (or are still trying to come out) with ambitious modernisation strategies. The introduction of new techniques (in products as well as in production) plays an important role in those strategies. The emulation of Japanese management concepts does too, for the obvious reason that the Japanese car producers have been so tremendously successful (see also Wood's contribution on 'Japanese managerial innovations'). The Japanese message is (among others) the same as that of the human relations advisors of the seventies: Team concepts pay off in terms of higher productivity, higher flexibility, speedy acceptance of new technologies, etc. Consequently, the car industry -and several other branches as well - has seen a plethora of team concepts applied in production, in planning as well in accompanying activites (quality circles) (Hackstein/Heeg 1986).

General Motors has been favouring team concepts on several occasions (Landen/Carlson 1982) and is currently involved in several far-reaching team projects. Widely debated, but so far only existing on paper, is the agreement between GM and the UAW concerning work organisation in the new small car Saturn division. A similar concepts is already in use for several years now in GM's engine plant in Austria. These projects involve the introduction of a team approach as part of the organisation of a whole plant. There are no comparable projects of that scale in the West German car industry. To some extent the presence of works 
councils legally representing all workers on issues of work organisation makes projects of the Saturn type more difficult to introduce and also less necessary. With support of the works councils, however, team concepts have been introduced in several areas of production and recently the general works council of VW signed an agreement with management concerning the introduction and organisation of quality circles (Volkert et al. 1987). Clearly, teamwork is becoming more important in the West German car industry, gaining support from management as well as from the union and works councils. Teamwork is no longer associated with somewhat esoteric humanization projects, but considered to be an important contribution to the overall competitiveness of the firms. How should this change be interpreted? What is the connection with the new technologies? In an effort to give some preliminary answers to these questions, this paper offers a brief review of the range of team concepts why these concepts can be useful for management in solving certain problems arising from the use of new technologies. Finally, the consequences for the quality of work are briefly explored and the factors influencing the selection of specific team concept are discussed with regard to the possibilities of influencing management choice.

\subsection{New competition and new technologies: a double challenge}

The process of crisis and restructurisation going on in the North American and West European car industries since the mid seventies reflects two major new phenomena. On the one hand the economic slow-down caused by the so-called oil crisis led to a slow-down in demand for cars as well as a shift in demand towards fuel-efficient cars. On the other hand the strong performance of the Japanese car manufacturers, with products that seemed to have anticipated the new demand patterns, put additional pressure on the car manufacturers in the traditional producer countries. The automobile market has become highly competitive again, with constant incentives to lower costs, improve the quality and increase the variety of models on offer. New techniques, bases on information technology, play an important role in this new competitive environment. In early analyses of the Japanese successes a lot of attention was paid to the numerous robots and automatic handling devices installed in their plants. All Western car manufacturers invested heavily in robotics and (later) in computer aided design and other automation projects - only to find out that an 'optimal' use of the new hardware required changes in the structure of the surrounding organisation, in management style, worker training and worker attitudes. What originally was thought to be a relatively simple question of hardware, turned out to be a much more complex problem of organisation change (orgware) and human resources management (humanware). There was also a correspondingly greater appreciation of the achievements and innovations of Japanese industry in this respect. Flexibility and quality were the keywords of their system, with low costs deriving from a policy of zero defects, minimal inventories and highly attentive and responsible production workers. The organisations that were faced by this formidable challenge had for many decades been developing in a different direction, based on the principles teached by Taylor and Ford. 
The basic principles of the 'Fordist' production organisation were a strict separation of planning and execution of work and detailed division of labour in production, based on the short cycle times of an assembly line moving at about 60 cars an hour. Production work that couldn't be planned in detail, usually involving skilled workers for instance for quality inspection and maintenance, was organised in special so-called indirect departments, located more or less close to the areas where the 'direct' work was carried out. Lower management had the task of translating and explaining the planning of work by the staff departments and controlling the workers and reporting back to the staff departments. The whole organisation was oriented towards mass production, presumably at the lowest cost. Quantity came before quality, in the sense that qualitative shortcomings were fixed later on in the production process by special repair workers. The ordinary workers on the line had no responsibility for quality and if provided with defective parts could either use them anyway or let the car go through without the part, so that it had to be fixed later on. By the late seventies the number of repair workers in Western car plants had increased appreciably and they had almost become a kind of 'hidden factory' inside the car factory. Western observers were then very surprised to learn that the Japanese car factories had almost no repair workers and no space reserved for the repair of defective or incomplete cars. The growing awareness of the shortcoming of their production organisation in a highly competitive, quality-oriented market encouraged management to develop a more comprehensive approach toward new technologies, integrating the use of new machinery and new information systems with new concepts three problems seem to have been particularly relevant:

1. The growing capital intensity of production;

2. the growing emphasis on quality.

3. the growing variety in car models and model specifications and optional equipment.

1. Over the past decade huge investment projects have been carried out in the car industry, a lot of them in information technologies and new automatic production equipment. Capital intensity of production has therefore been rising, influencing the structure of production costs. Consequently, in some parts of the factories it becomes more important to keep machinery from standing idle (see Christis in this reader on 'functional structure') than to save on labour costs. 'In this part of our body shop', explains one manager in firm A, 'we have replaced about 175-200 workers by a number of robots which can be handled by 25 workers. It doesn't matter very much to the firm if there are 25 or 26 or 27 workers: what matters is that these robots do not stand idle and that is the main task of the workers here.' The body shop which everywhere (together with the paint shop) has absorbed the largest number of robots, has become the prime example of changing work patterns in relation to changing techniques. Basic issue here is the position of the formally 'indirect', maintenance workers, who ideally should be available for immediate intervention in case of a breakdown of the installation.

2. The growing emphasis on product quality has led to pressure on the part of manufacturers to deliver higher quality as well as to a search for possibilities of an integration of inspection and quality control in the production process. However, such integration is only possible if production workers, have the time to inspect 
their own work, to reject and replace defective parts, etc. In Japanese factories this necessity has led to the (seldomly used) possibility for production workers to stop the assembly line.

3. Intensified competition has resulted in a greater variety of model specifications being offered to the consumer. The possibilities offered by programmable machinery are being used to produce various models on the same production line. All this causes great problems of line balancing, especially in final assembly, where cars differ greatly in required assembly time, depending on the kind of equipment that comes standard on the various models, or has been ordered by the customer. Work on the assembly line is based on the assumption of a roughly equal number of cycle times per car and every departure of that assumption results in longer assembly lines in which some stations are only used for some cars and not for others or in crowded work situations, where workers come in each other's way with negative impacts on quality. One obvious solution is to have some larger components of the car assembled off-line, and then install them in one piece. This may require a redesign of those parts. Another solution involves cooperation with parts suppliers. Greater product variety has often entailed a greater dependence on outside suppliers for specific parts. The next step is to ask these suppliers to deliver the parts just-in-time for assembly.

\subsection{The teamwork approach}

Teamwork in production is expected to contribute to the solution of the problems mentioned above. Several concepts of teamwork have been developed in the West German car industry, varying in scope and in aim. A useful distinction can be made between the following three types:

1. teams in highly mechanized and automated work environment;

2. teams in off-line assembly activities;

3. teams or group work on the assembly line.

1. In the early eighties firm B has introduced teamwork in its modern body shop, where almost all spot welding operations have been taken over by an army of about 140 robots and some dedicated machinery. The main body assembly line has been divided up in three sections (floor pan welding, lower section assembly, body build-up course), which are clearly separated from each other. Work in each section is carried out by a team, which is thus technically and physically independent from the others. The production of sub-groups (for instance side and rear panels, roofs) is also decoupled and apportioned to separate production teams. Each team is responsible for production, maintenance and quality inspection in its section. The interesting new features of this set-up is the transfer of maintenance and inspection tasks to production teams. Direct and indirect work have been redivided. Of course, there are still separate departments for quality control (audit) and maintenance/repair, but several more or less routine tasks of these departments have been transferred to production. Incidentally, not only the tasks, but also several dozen workers (inspectors) have moved out of quality into production, i.e. they have become 'direct' workers. The more noticeable aspect of this new set-up, however, is the increase in responsibilities for production workers, 
which has been made possible by an 'immense training program' (one manager).

Each team consists of one line controller (Strassenführer), one or more robot/installation-minders, one or more inspectors, several parts loaders, and eventually some other personnel if required. Obviously, the teams are not homogeneous: Job descriptions and wage levels differ between team members. Nonetheless the workers are expected to function as a team and special attention has been paid to the involvement of the workers on the jobs with the lowest skill requirements (the parts loaders). A manager described their tasks as follows: 'The loader's task basically involves keeping the parts supply silos for the automatic welding systems filled and placing small parts in the magazines and fixtures. In addition, they have a monotoring function to perform in the section of the plant which they can see, with a view to identifying malfunctions as soon as possible or initiating preventive action before tasks in their areas, for example the replacement of electrode-caps, and assist the line controller and the robot minder or skilled repair staff if more extensive repairs have to be carried out. ' The line controller and the robot minder are obviously the more qualified persons on the team. Long before the new production line started up, about 40 skilled workers (Facharbeiter) of the old body shop were selected for these functions. Apart from their responsibilities for production, it is also their task to teach the loaders and encourage them to assist in maintenance and repair activities.

Management's motives for the new set-up are clear: skilled work is mostly needed when there are problems and production comes to a standstill. Unskilled work (loading) is going on, when the line runs without problems. If both kinds of work are carried out by the same person, less personnel is needed to run the plant. Besides that, it can be expected that the presence of many qualified workers will increase the uptime of the installations, which is becoming an important consideration where capital intensity of production is increasing rapidly. Recently, the same firm has set up a new body assembly line for a new car model. The team work approach has also been applied on the new line and management show itself satisfied with this type of work organisation. Figure 5.1 provides an overview of the new body shop, the number of persons working there, the teams and the job structure (some so-called production teams, that are responsible for a technically defined section, have been divided up again in teams of a workable size). Differences with the earlier set-up are to be found in a greater number of devices for the automatic feeding of parts and in the disappearance of some tasks out of the job descriptions of the team members.

These tasks had to be carried out so seldomly that team members didn't have enough practice and after a while felt no longer qualified to carry them out (for instance manual driving of robots back into their starting position). These tasks returned to maintenance personnel. One remarkable development should be noted here: almost all workers in the body shop, also the parts loaders, have completed formal training in one of the metal workers trades and are skilled workers (Facharbeiter) in that sense. The labour market situation has allowed firm B to engage many skilled workers for direct production tasks, which used to be carried out by semi-skilled workers. In assembly work 60 or $70 \%$ of the workers are now 
Figure 5.1

\section{Production teams in a modern body shop}

\section{Flow Diagram of Body Shop} with Production Teams

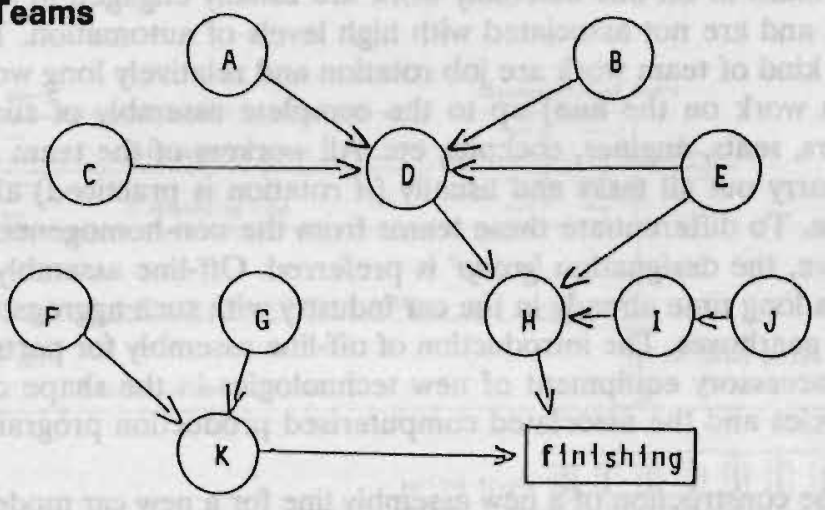

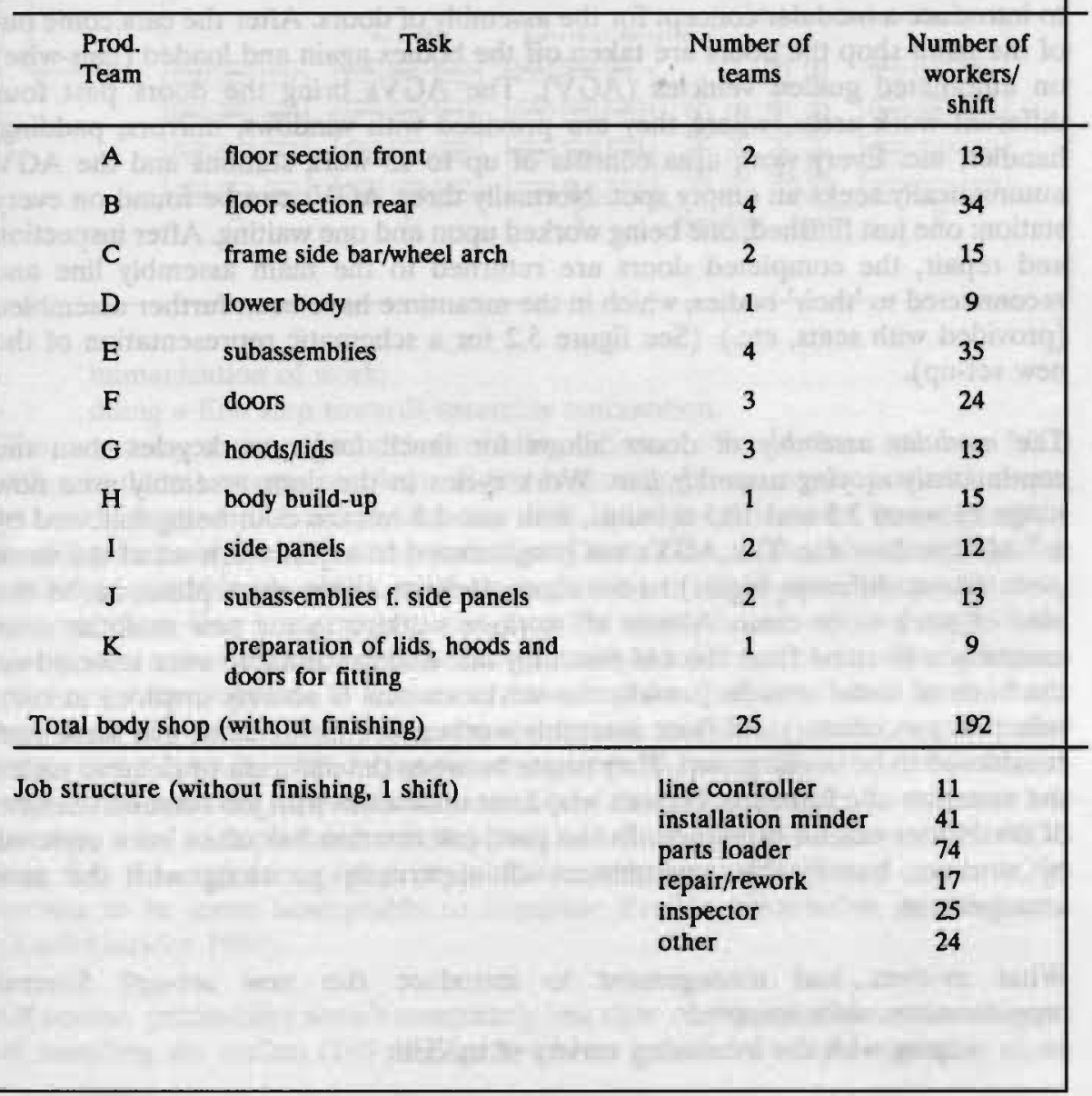


formally skilled workers. The availability of such highly skilled workers makes it relatively easy to introduce team concepts and transfer responsibility for quality and maintenance to the shop floor.

2. Teams in off-line assembly work are usually engaged in tasks that require less skill and are not associated with high levels of automation. The main features of this kind of team work are job rotation and relatively long work cycles (compared with work on the line) up to the complete assembly of such sub-assemblies as doors, seats, engines, cockpits, etc. All workers of the team are equally qualified to carry out all tasks and usually (if rotation is practiced) all will earn the same wage. To differentiate these teams from the non-homogeneous teams mentioned above, the designation 'group' is preferred. Off-line assembly had been practiced for a long time already in the car industry with such aggregates like axles, engines and gearboxes. The introduction of off-line assembly for parts of the car body and for accessory equipment of new technologies in the shape of automated guided vehicles and the associated computerised production programming.

In the construction of a new assembly line for a new car model firm $\mathrm{C}$ has decided to introduce a modular concept for the assembly of doors. After the cars come out of the paint shop the doors are taken off the bodies again and loaded (pair-wise) on automated guided vehicles (AGV). The AGVs bring the doors past four different work areas, where they are provided with windows, mirrors, padding, handles, etc. Every work area consists of up to 15 work stations and the AGV automatically seeks an empty spot. Normally three AGVs can be found on every station: one just finished, one being worked upon and one waiting. After inspection and repair, the completed doors are returned to the main assembly line and reconnected to 'their' bodies, which in the meantime have been further assembled (provided with seats, etc.). (See figure 5.2 for a schematic representation of the new set-up).

The modular assembly of doors allows for much longer workcycles than the continuously moving assembly line. Work cycles in the door assembly area now range between 3.5 and 10.5 minutes, with one 3.5 minute door being followed by a 7 Minute door etc. The AGVs are programmed to adjust the level of the work piece (three different hights) to the characteristics of the work place, i.e. to the kind of work to be done. Almost all workers working in the new modular door assembly unit came from the old assembly line and presumably were selected on the basis of social criteria (usually the works council is actively involved in such selection procedures). All door assembly workers are in the same pay scale and considered to be in one group. They rotate between the different work areas under the direction of a foreman. Persons who have difficulties with job rotation because of disabilities can be exempted. In the past, job rotation has often been rejected by workers, but in this environment all apparently go along with the new arrangement.

What motives had management to introduce this new set-up? Several considerations were involved:

coping with the increasing variety of models; 
Figure 5.2

\section{Schematic representation of modular door assembly}

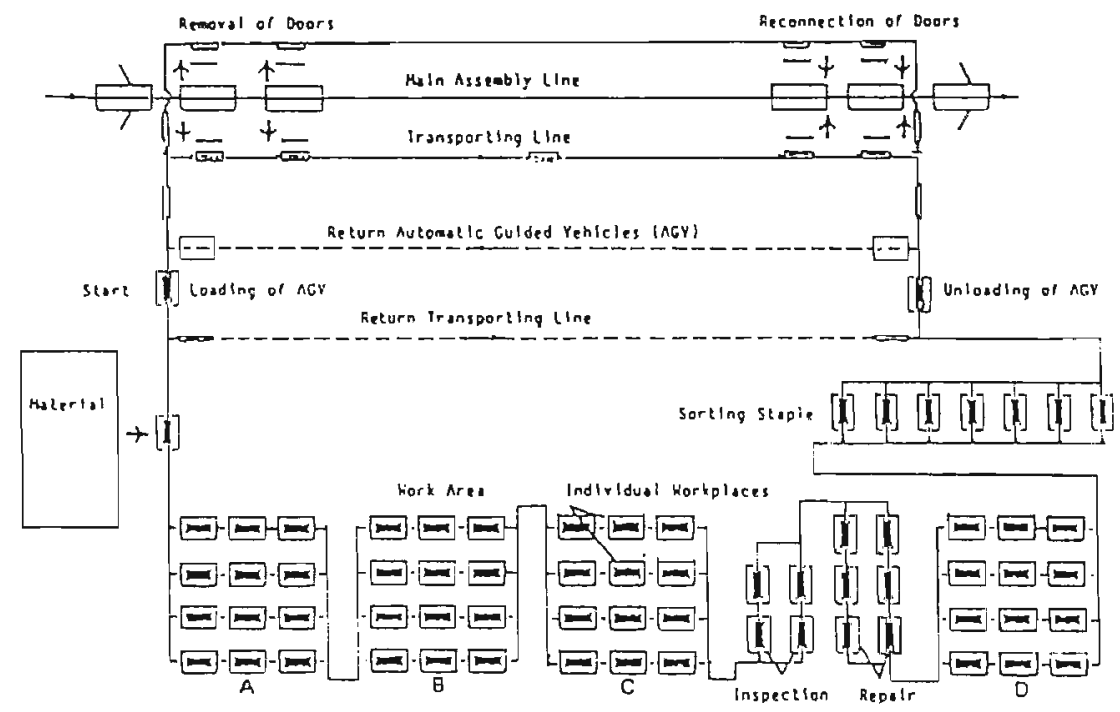

- humanization of work;

- doing a first step towards assembly automation.

The increasing variety of models (including different colours, there are over 3.000 different doors) creates problems of line balancing, of course not just with doors, but with many other components as well. Such problems can be reduced by modular assembly outside of the main line. There is no reason, however, why such modular assembly shouldn't itself be organised in a conventional roundabout assembly line. One manager, who was sceptical about the new system, argued that investment costs for a conventional line probably would have been $1 / 40$ of the costs of the system installed. In that case, however, the quality of work would have remained the same. Improving the quality of work supposedly was another important motive for introducing the new system. In fact, deliberations started with arguments in favour of a modular assembly of the cockpit, which on the main line involves a lot of unpleasant overhead work. A final argument in favour of AGVs was that the engineers expect modular assembly operations based on an AGVsystem to be more susceptable to complete flexible automation in the future (Koch/Gericke 1986).

Of course, profitability wasn't completely lost sight of. Against the enormous costs of installing the system (140 AGVs have been installed for door assembly alone 
and the system also uses much more space than a conventional line) stand important savings. Some of them are clearly visible, like the elimination of at least 34 door assembly jobs (less waiting and walking). Others are less visible, but not unimportant. With the doors taken off, many other assembly activities also become easier (require less time) and material can be put closer to the line. In the old system doors were often damaged in the course of assembly operations. With the new system there is less damage and consequently less repair. Also, in the new setup the worker him/herself pushes away the AGV after finishing his/her job, which means that there will be less unfinished work and consequently less need for inspection and repair than on an ordinary line. Although quality control was maintained as a separate function in this specific case, it can easily be integrated in the tasks of the group (self inspection).

AGVs have also been used in the 'finishing' area of the body job of firm $D$. The area has been divided up in four zones with different tasks: spot welding, soldering, abrading, connecting of doors, hood and trunklid.

Built-up bodies enter the area mounted on AGVs and are guided through the four zones (in the order mentioned). Every zone consists again of several work stations, where small groups of two or three workers carry out the necessary operations. AGVs are automatically guided to an empty work station. All groups can handle all car models and every worker has the same qualification. Work cycles vary from 2 to 10 minutes. Between every zone is a buffer area. Here again, the main advantage from the management point of view is the elimination of imbalances and therefore unavoidable waiting in the traditional linear set-up, because of differences in work load between cars.

AGVs are guided by signals transmitted by wiring in the floor of the plant. The whole system is computer-controlled and there is usually a control stand somewhere overseeing the area with the AGVs. At the control position, the location of every AGV can be read on a monitor as well as the work stations it has been in and the time it has spent there. Thus, in principle there systems provide all the information needed for controlling the performance of individual work stations (and even of individual workers, where there is only one person on a station). The computer knows the standard times for the various operations that have to be carried out in every station on every work piece and it would be easy to signify each station (e.g. by a light switching on) if it is taking more than standard time. Workers and works councils, however, have resisted the introduction of such close control mechanisms, which would provoke constant interventions and observation by the supervisors. In the door assembly case, what is left is a light switching on as soon as an AGV has been in a work station for more than the average cycle time (which may be warranted in case of a more than average work load for the particular door). In the body finishing area, each zone has a sign showing the total number of 'standard' minutes of work that have been completed so far during the shift (i.e. the sum of the standard times of all the bodies which passed the zone, divided by the number of workers). Everyone can easily see then whether the groups has been working somewhat slower than the other. It is left to people in the zones to see to it that everyone is having about the same work load. 
3. A third kind of 'teamwork' which should be mentioned here concerns the formation of groups on the production line. Examples can again be found in the body shop as well as in final assembly. Like firm B firm E has mechanized $90 \%$ of its spot welding operations and almost halved the number of workers in the body shop. Here too, workers on the body assembly line are organised in groups. But the groups are small ( 3 or 4 persons) and homogeneous (all members are in the same wage bracket) and the different sections of the line are directly connected with each other. Within the small groups there is job rotation: loading is combined with inspection or with the reading of production assignments and machine monitoring functions. Because of rotation the workers have come into a higher wage bracket. Slightly more qualified work like that of the line repairman (Nacharbeiter), is not combined with loading. One generally gets the impression that in this plant, management is presently not especially interested in upgrading production work through job enlargement and integration of direct with indirect tasks. Group work and rotation are mainly seen as a means of ensuring (see Atkinsons's 'functional') flexibility and availability of productive capacity. Tooling up, maintaining and monitoring equipment have been assigned to the maintenance department. Even the simple tasks like changing electrodes and renewing air-hoses, which firm $\mathrm{B}$ has given to production, remain with maintenance.

Maintenance troops are stationed close to their assigned sections of the body shop. Whereas in firm B a production man (the line controller) is responsible for practically everything in his section -apart from major technical failures- in firm $\mathrm{E}$ responsibility is shifting to the (indirect) maintenance department. Actually, the maintenance troops located in the production area ressemble the work teams of firm $\mathrm{B}$ to the extent that they are also non-homogeneous, with different pay scales and different trades. As in the production teams of firm B there is no strict rotation but forms of co-operation do exist. The maintenance troops (but remember that in firm B semi-skilled work was done by formally skilled workers).

Another example concerns the formation of groups in final assembly. Firm $F$ is presently considering the possibility of making groups of workers on the assembly line responsible for specific packages of tasks -like all tasks having to do with the installation of seats, or of the engine, or of the cockpit- giving them some identity by marking off 'their' area of the assembly line and by reporting back to them about their performance. The groups would be encouraged to cooperate, even to the extent that standard times would no longer be provided for every individual task and worker but to the group as a whole for every car. In the present situation, with a large variety of cars rolling off the lines, it is unavoidable that assembly workers have different work loads on different cars. One worker may be finished in 30 seconds, whereas the other would need 2 minutes. The idea of standard times for the whole group implies that the $30 \mathrm{~s}$. worker would finish his/her task and help the colleague with the $120 \mathrm{~s}$. task. At the time of writing this is still an experimental project and a lot of questions remain regarding its viability. It should remind us though, as one manager said, that 'the assembly line isn't dead yet; there is probably still a lot of productivity-gain to be achieved there.' (Van Eijnatten et al.) report on a project in a Dutch assembly plant for trucks, where similar groups in final assembly are also responsible for the (sub) assembly of the parts they are 
putting into the vehicles - apparently a combination of the second and third type of teamwork mentioned in this paper).

\subsection{Consequences for the organisation and for the workers}

The concepts of teamwork presented here promise to solve some of the problems that come with the new technologies and the new competitive strategies. Teamwork is aimed at the elimination of down times on expensive machinery; at the incorporation of maintenance and quality control in production and at the prevention and elimination of imbalances in the assembly process. The traditional Fordist production organisation is challenged in all its major characteristics. Assembly cycle times are becoming longer and often are no longer machine-paced. Direct production tasks are combined with indirect tasks and detailed planning of production tasks becomes consequently more difficult, if not impossible. The strict separation between planning and execution is increasingly being questioned by the growing emphasis on the responsibility of workteams for product quality and work organisation. This corresponds also with observations on practices in Japan: 'While line balancing analysis in Western industry is usually a staff engineering function, Japanese foremen will often lead the production line balancing effort.' (Schonberger 1982, p. 115). The same observation can be made if one looks at the consequences of just-in-time delivery systems. What the 'Kanban' system amounts to is a transfer of production steering activities back to production, because it is only there that the actual need for specific parts and materials can be determined immediately and on an on-going basis. As a consequence of 'Kanban' production can no longer blame planning failures in the staff departments, if parts are not available: production is itself responsible for ordering those parts in time (Freimuth 1987).

What then do all these changes mean for the quality of work of the individual worker? Does the demise of the Fordist organisation, which has usually been associated with a low quality of work, hold promise for the workers? Or is the scepticism voiced by many workers and unionists as noted earlier justified? The problem is that these questions usually cannot be answered by a simple yes or no. There is first of all the general problem of comparing the old with the new situation. Do we compare the new jobs with the old jobs in the same location? Or do we compare the old workers with the new ones? What if they are not the same? Do we have to investigate where the old workers went to, and where the new came from? And what to say of the impact of the new work organisation on jobs in other parts of the firm? Where do we draw the limits of the unit we want to investigate? Even if all these questions have been sorted out, there is the difficult problem of deciding upon a suitable measure of quality. In the examples of assembly groups given above for instance, fewer workers are needed to assemble the same number of doors or seats. In that sense, work has clearly become intensified. Because of the new set-up, without pacing by the line, with longer work cycles and with much easier access to the work piece, work may appear actually easier and less intensified to the worker. Job rotation, on the other hand, may be rejected by the worker, because it means that he or she has to adapt regularly to 
changing job requirements, but the regular changes in body movements may be better for the worker's health. Finally, every detailed investigation into the quality of a type of work organisation like teamwork shows that much if not everything depends on the concrete modalities of their introduction. In other words: the design of teamwork is a process of choice, often also a process of bargaining and the eventual quality of work depends on the choices made, the agreements reached and the circumstances influencing these selection processes.

While keeping in mind these many restriction on any sweeping analysis, some general remarks about the impact of teamwork on the quality of work can still be made. The familiar concepts of job enrichment and job enlargement, respectively referring to the vertical and the horizontal dimensions of a job, may serve to organise the argument here (Bailey 1983, p. 78).

Teamwork can be expected to imply job enlargement for production workers in the sense of lengthening work cycles, providing for job rotation and including formerly indirect but relatively routine tasks in the area of quality control and maintenance. At least in West Germany these features of teamwork are normally approved by the workers and actively demanded by the works councils. Usually this broadening of tasks also implies a higher wage for the teamworkers. Most of the firms put a considerable effort into training and preparing the workers for the new environment, which further seems to underline the improved quality of work.

There are some signs that teamwork may also imply job enrichment in the sense of providing the team members with a measure of autonomy and self-regulation. Features like self-inspection, the AGVs that stay in the work station as long as the worker(s) consider(s) necessary, the responsibility for failure detection and timely intervention (in the body shop) point in this direction. The automobile industry, however, still is and remains a mass producing industry, which implies that the autonomy of the individual work teams will always be limited by the overall flow of production. It can be argued that especially the new information technologies have provided management with the means for new forms of overall, integrated or systematic control. The newly-won autonomy of production teams is conditioned by this increase in management control. Whether this so-called controlled autonomy (Dohse et al. 1985) will be experienced as an improvement in the quality of work depends on the balance between the two aspects control and autonomy, which will probably be the subject of continuous bargaining (like the bargaining on the use of control lights on the AGVs mentioned above).

In this vertical dimension of the changes engendered by teamwork lies the main challenge for lower and middle management. If lower management insists on retaining the old Fordist topdown style of management and tries to use information technologies for purpose, there is a good chance of the team approach to break down. 'Our biggest problem is management in the plant: the shift leader, the foreman, the assistant foreman. They don't have knowledge about new trends in work organisation and are surprised by the new developments. They don't know how to evaluate them.' In firm $G$ the industrial engineering department is organising two hour speak-out sessions between workers and foreman (during 
worktime) as part of the effort of introducing a different, more team-oriented management style.

Another obstacle needs to be mentioned here in connection with vertical dimension of teamwork: in most team concepts a team speaker is envisaged, especially where the teams are somewhat bigger. In West Germany, this is a sensitive issue in the relations with the union and the works councils. Team speakers might easily undermine the position of shop stewards (Vertrauensleute) and members of the works council. The latter will therefore try to ensure that official team speakers will be identical with the union's shop stewards. So far, however, this hasn't become a big issue yet. Management hasn't been pushing for the creation of a position of team speaker or group leader, but we expect that someone in the group will grow into that role and then we wouldn't mind if she or he would also be a union activist.'

\subsection{Environmental influences on the quality of teamwork}

In the final analysis then, the quality of teamwork depends on 'the politics in and of production', i.e. on a complex process of bargaining and decision making. The outcome of that process, however, is also dependent on the structure of the environment in which it takes place.

Four such environmental influences can be mentioned, that seem to be of particular relevance for the introduction of teamwork in West Germany:

1. the supply of skilled workers; 2 . the wage structure and especially wage differences between skilled and semi-skilled workers; 3 . the prevailing work organisation and especially the existing division between direct and indirect work; 4. the rights of co-determination of the works councils.

1. Skilled workers (Facharbeiter) have traditionally stayed out of direct production work in the car industry, but recently things have changed. Relatively high unemployment forced skilled workers to apply for jobs in production. At the same time, as noted above, the introduction of new technologies created a certain need for higher qualified workers in production. Where skilled workers occupy production jobs, it is relatively easy for management to engage in job enrichment (teamwork) and there is even a certain pressure to do so in order to motivate the workers to stay on those jobs. Unemployment has been high for unskilled workers and especially for young unskilled workers. In its campaign against youth unemployment, government has been encouraging young people to acquire more skills and education. It has put a lot of pressure on firms to take on apprentices. Consequently, most car manufacturers have more apprentices than their foreseeable requirements for skilled workers would justify. If these workers want to stay in the firm after their apprenticeship, they will have to take production jobs. Data provided by the IG Metall for 11 car plants employing 303.939 persons in 1985 show that the number of apprentices increased by $26.1 \%$ between 1983 and 1985 (from 8.435 to 11.016 ), whereas total employment increased by $4.3 \%$ over the same period (IG Metall 1986). 
Figure 5.3

Wage Differentials In Three Countrles
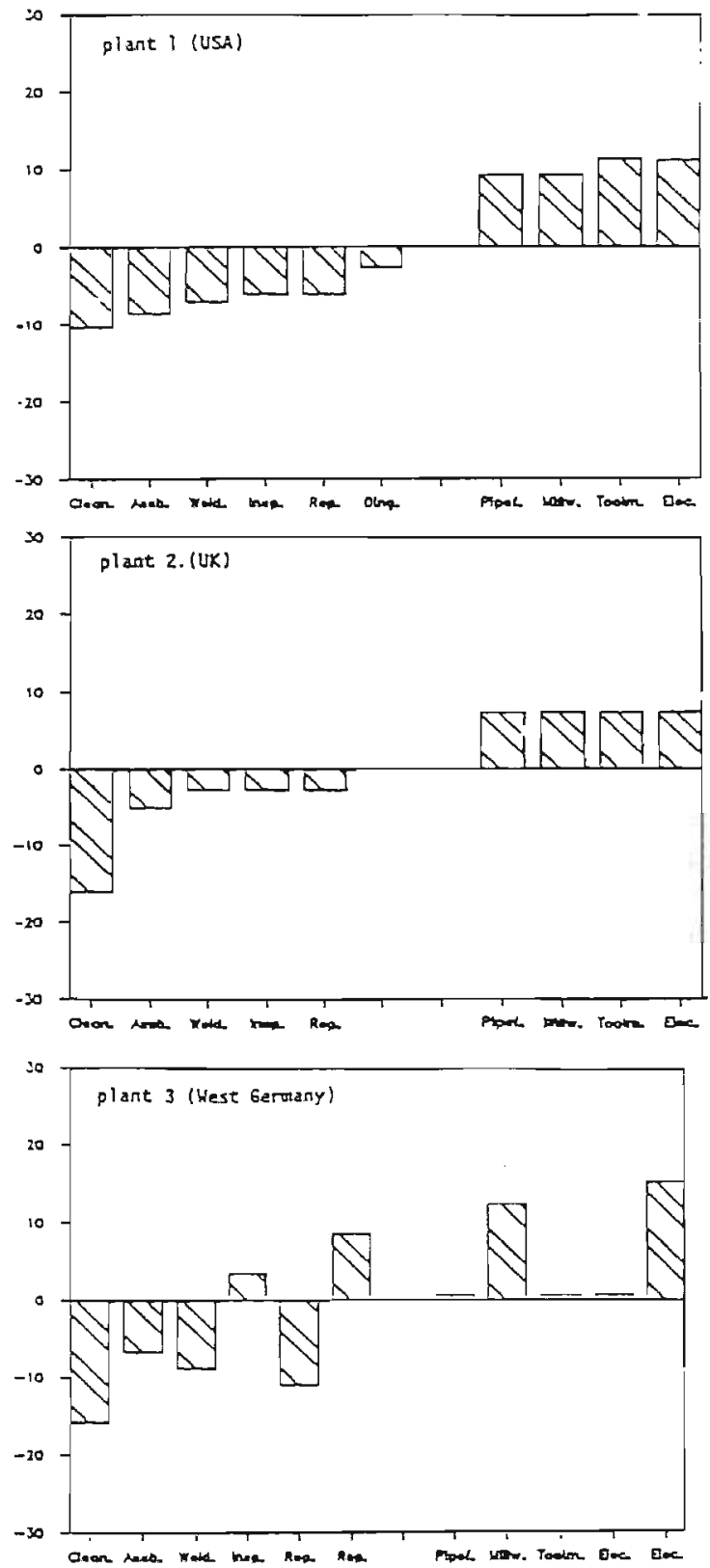

Wage differentlals (wages expressed as a $\%$ of average wage) in car plants In the USA (plant 1, 1981), the UK (plant $2,1981)$ and Weat Germany (plant 3, 1983) for un- and seml-skllled workers (cleaner, assembler, welder, Inspector, repairman, dingman) and skllled workers (plpefltter, mill. wright, toolmaker, electrlclan, electronics speciallst) 
2. Another important environmental factor influencing the ease or difficulty of introducing teamwork is the prevailing wage structure. Because of broader job descriptions and job rotation teamworkers often receive higher wages than traditional workers on the assembly line. How much higher depends on the system of wage determination. Obviously, rising wages represent rising costs and if the costs become too high, management will try to search for other solutions or even give up on the teamwork approach. Especially where production workers engage in tasks that used to be carried out by skilled, indirect workers, the question of wage differentials between skilled and semi-skilled workers might come to play an important role. Comparative research shows that West German car manufacturers may face fewer problems here than their American or British counterparts. Figure 5.3 shows wage differentials between un/semi-skilled workers and skilled workers in three comparable car plants in the UK, USA and West Germany. In the West German car plant earnings in several semi-skilled jobs are higher than in skilled jobs. Creating a new mixture of skilled and semi-skilled tasks may therefore be less costly and less encumbered by status problems than in the other two countries

3. In every process of reorganisation the current organisational structures always play an important role. For the introduction of teamwork in West Germany the prevailing distinction between direct and indirect production work has to be taken into consideration for instance, because it touches upon rules of co-determination. The West German legislation on co-determination prescribes that management cannot change the type of wage for any category of workers without the consent of the works council. Thus, if quality control workers are paid a time rate (which sometimes is the case if they are treated as indirect workers), they cannot be transferred to production, where they would earn a productivity-related wage (measured day work) without the consent of the works council.

4. This leads to the fourth factor of influence that should be mentioned briefly: the position of the union and the works council, their legal rights and their traditional position. The presence of influential and well informed works councils in all West German car producing firms, their legal status which makes their strength less dependent on the prevailing labour market situation and their good relations with the general works councils can afford to take a long-term strategic view of the car industry and to be appreciative of the car manufacturers. The IG Metall, moreover, has been engaged in various experiments and research projects within the framework of the Humanization of Work Program of the Ministry of Research and Technology. It has accumulated considerable knowledge in this field and has developed an advisory structure to support the works councils in such issues as work restructuring, job redesign and teamwork.

Considering these circumstances it may be allowed to conclude with the optimistic note that teamwork in the West German car industry can be expected to bring an improvement in the quality of work. 


\title{
6. Technical Change and Industrial Relations. Theoretical reflections on changes in the automobile industry
}

\author{
6.1 Industrial relations and the employment relation \\ 6.2 Unilateral or joint regulation, conflict and consensus \\ 6.3 Technical change and the organization of work \\ 6.4 Technical change and industrial relations in the auto industry
}

This paper is an effort to deal with some theoretical problems arising from a comparative research project on the automobile industry. The project explored the implications of new production technologies for work organization in relation to international differences in industrial relations systems. Technical change was assumed to present options for work organization and the choice between these options was expected to be influenced by the prevailing system of industrial relations. Changes in work organization were investigated in comparable plants of three multi-national car manufacturers, located in three different countries (Great Britain, West Germany and the USA). Presumably, differences within one country would have to be explained by differences in the policies of the firms, whereas differences between countries would have to be explained by (among other things) differences in the organization of industrial relations of those countries. It was found that, indeed, differences in work organization between firms within one country, although certainly not to be neglected, were relatively small compared to differences between countries. On the part of each corporation, some efforts are visible to develop a more or less unified, corporation-wide approach to questions of automation and work organization, but these efforts are in their outcome strongly affected by existing national patterns of labor relations, labor market institutions, health and safety regulations, training systems, etc.

Empirical findings thus seemed to conform to the expectations that went into the research design. A major theoretical problem appeared, however, because of the fact that during the period under investigation in all three countries industrial relations in the automobile industry were changing more or less rapidly. Especially for Great Britain and the USA several recent studies suggest that decisions concerning the application of new technologies had far-reaching consequences for

\footnotetext{
' Published in Economic and Industrial Democracy, Vol. 10 (1989), pp.99-121. A first version of this paper was written while the author was employed at the Wissenschaftszentrum Berlin für Sozialforschung, in the project 'Risks and Chances for Workers of the Present Restructuring in the World Automobile Industry'.
} 


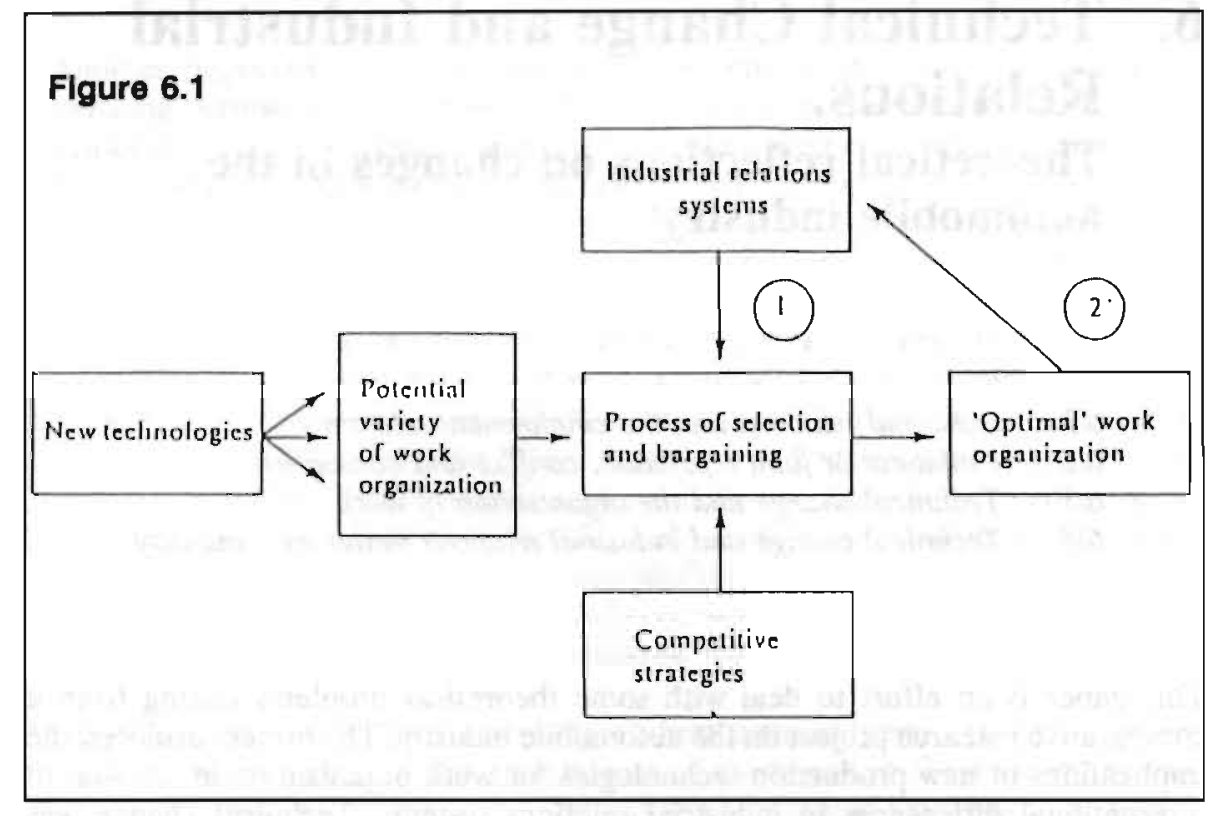

the industrial relations system (IRS). A completely different perspective thus seems possible: not the IRS influencing the choice of work organization, but these choices influencing the IRS (Katz 1984, 1985; Katz/Sabel 1985; Marsden et al. 1985; Streeck 1985a; Willman 1982, 1986). To phrase it differently: whereas the research design had proceeded on the assumption that decisions on work organization are taken within a time frame in which the industrial relations system can be taken to be unchanged, at least in the early eighties it was possible to argue that the IRS in some countries was changing as rapidly as work organization. That by itself doesn't exclude the possibility that the IRS influences choices in work organization, but if the changes in the IRS are somehow caused by those in work organization the argument breaks down. Figure 6.1 offers a graphical representation of the argument. Work organization is depicted as the outcome of a process of selection and bargaining. The work organization that results from the process of selection and bargaining is called 'optimal' in the sense that it is supposed to be the best attainable compromise for all parties concerned under the given circumstances. The project research design was aimed at investigating relation (1) and hardly considered (2). If relation (2) is important, however, the meaning of relation (1) becomes unclear, because the IRS can no longer be treated as an independent variable. Thus, fundamental questions were raised concerning the relative stability of the IRS, the factors underlying its structure and the process of its construction. In order to deal with this type of questions, a conceptual framework is developed in the following sections. We start in section 1 with the notion, that the industrial relations system has the function of regulating the employment relation. Section 2 then takes a closer look at management's role in the process of regulation and considers some of the criticism of the systems approach with special attention for the problem of structural change in the IRS. Section 3 deals with technical change 
and the way it enters into the employment relation. A final section uses the conceptual framework in a brief analysis of recent developments in the industrial relations of the automobile industry in the three countries mentioned.

Those who are familiar with the industrial relations literature will no doubt recognize much of what follows. One source of inspiration has been John Dunlop's seminal work (1958) and especially its reception in British industrial relations literature (Goodman et al. 1975; Wood et al. 1975; also Poole 1981 for an interesting survey; Schienstock 1981).

As a second source I should mention the recent work by Burns, Baumgartner and Deville on actor-system dynamics (1985), especially where it allows more clearly for (strategic) action in a rule-structured environment.

Finally, the following has also been inspired by the ongoing debate about the meaning of strategic choice for the relations between an organization and its environment in general and for industrial relations in particular. In this context, especially strategic decisions by management have recently been emphasized (Schreyögg 1980; Timperley 1980; Kochan et al. 1984).

This paper doesn't pretend to be a faithful exposition or interpretation of these sources of inspiration. It is just an effort to use some of the concepts found there, especially from the systems tradition in industrial relations, to see if they can contribute to an understanding of the theoretical problems mentioned above.

\subsection{Industrial relations and the employment relation}

The employment relation is a relation of exchange. The employee is selling his or her capacity to work a number of hours per day to the employer, who pays a wage or salary in return. Analysts of the labor market concentrate on the explanation of the price of labor and consequently speak of the employment relation as the wage relation. On the labor market we find not only individual workers and employers, but also unions and employers' associations who engage in collective bargaining. Bargaining on the labor market ends with the signing of a labor contract. Labor market research thus concentrates on one dimension of the exchange relation: on the money and other benefits flowing from employers to workers. We are here more interested in the other half of the transaction: the flow of work efforts from workers to employers. Labor contracts may be more or less specific about the jobs that have to be done, but it is only when the jobs are done, that workers find out what exactly is expected from them and that employers find out how good the workers are on the jobs they have applied for. Almost every employment relation is characterized by some implicit or (less often) explicit 'bargaining' over the effort that can be reasonably expected from the employee. Bargaining on the labor market ended with the signing of the contract, but then on-the-job bargaining starts and remains a less visible, but certainly just as important element of the process of exchange.

The 'Industrial Relations System' consists of all activities, actors and procedures involved in regulating the process of exchange between employers and employees. 
Within the system we identify actors and procedural rules, a structure and a process. Actors in the IRS are the employer and the employed themselves, but also employers' associations and labor unions as well as government and its relevant agencies. Together and in interaction with each other, these actors produce a more or less coherent set of rules ( $a$ regime of job regulation) regulating the behavior of employers and workers in the employment relation. The production of rules governing the employment relation is itself a process regulated by rules: it is useful to distinguish between the procedural rules regulating the relations between the actors in the IRS and the substantive rules produced by them to regulate the employment relation. The IRS is a multi-layered system in which higher levels may produce procedural rules for lower level actors. On the lowest level we find the individual worker and/or his or her representative on the shop floor (shop steward) interpreting and bargaining over the terms of his or her labor contract with the employer or rather with the agent of the employer (the supervisor) on the shop floor. Actors at that level are active in the execution of the labor contract, acting out the employment relation, guided by the rules established in the IRS, and at the same time they contribute to the creation of new rules, customs and practices which eventually may even become part of labor contracts (this process of formalization of informally developed rules and regularities is called reinstitutionalization by Goodman et al. 1975). Above the individual/shop floor level (actors: workers, shop stewards, supervisors) one may distinguish the level of the plant and/or firm (actors: works councils, shop steward committees, union locals, plant or firm management), the level of industry (actors: industrial unions, employers' associations) and the national level.

The industrial relations system is an analytical construction. Actors can be active in different systems at the same time. Workers and supervisors at the lowest level of the IRS e.g. are also active in a production system, in which they cooperate in the production of commodities, together with other actors who are not part of the (same) IRS.

The (internal) procedural rules define the structure of the industrial relations system by circumscribing the roles and responsibilities and the interactions of the actors at the different levels. The structure is a property of the system as a whole, an expression of the relations between all actors as a result of all rules, and as such it is relatively robust. Individual actors may change (governments e.g.), grow or amalgamate (unions, firms) and individual procedural rules may be amended without greatly affecting the structure of the system. It should be noted that these rules have been created by the actors themselves. This is the main reason why government is commonly identified as an actor within the system, because in almost all capitalist countries, governments have been involved with or have interfered in the process of defining the basic rules of the IRS. So, even in those countries where government is hardly involved in the actual process of regulating the employment relation, it can still be considered as important actor in the system.

The structure of the IRS gets reflected in the regime of job regulation produced by the system. However, just as in a game the rules do not determine which player will win (though they might limit the losses of any player), so in the industrial 
relations system the procedural rules alone do not fully determine the actual process of job regulation and the substantive rules (the regime) coming out of this system. The process (or game) of job regulation is an ongoing process in historical time. The procedural rules and the structure of the system may be more or less favorable to any of the actors, but the relative strength of the actors and the strategies followed by them also play an important role. Specific rules of job regulation therefore also reflect the relative strength of the actors at the time when the rules were made. It isn't easy to define relative strength independently from the outcome of the process of regulation, but it is fairly obvious that such factors as the situation on the labor market; the political color of government; and even the individual shrewdness of labor leaders or employers can affect the relative strength of the actors in the IRS and therefore the rules produced by the system. Even a complete knowledge of the structure of the IRS, therefore, doesn't enable us to predict precisely the rules of job regulation produced in this system. The explanation of any specific rule or any specific set of rules (regime) requires knowledge of a larger set of variables in the context of the IRS, which influence strength, perceptions and strategies of the different actors.

Figure 6.2 provides a graphical representation of the conceptual framework outlined above. In the center of the figure is the employment relation. Workers exchange efforts against wages with employers who employ them within the framework of a competitive strategy. The terms of exchange are regulated by the prevailing regime of job regulation - a set of 'rules of the game', some of which are firm-specific whereas others have a wider applicability. The actual exchange going on in a firm is not only dependent on the prevailing set of rules, but also on the strategies and attitudes of the individual employer and the workers concerned. These actual terms of exchange are one of the determinants of the competitive performance of the firm, which on the one hand feeds back into competitive strategy and on the other hand influences demand for labor. Demand for labor by all firms determines the level of employment, which in turn is a major factor in the explanation of workers' attitudes and unions' strategies (and their strength vis-a-vis the employers). The rate of unemployment and other macro-economic criteria are an important input into government policy making concerning industrial relations. In the figure, a clear distinction is made between rule-guided behavior within a specific employment relation, which is naturally mainly a concern of local management, (groups of) individual workers, shop stewards, works councils, etc. and (strategic) actions within the industrial relations system aimed at formulating rules for the employment relation. Such actions within the industrial relations system are guided by another set of (procedural) rules, which constitute the structure of the IRS. Behavior within the IRS may also be aimed at changing these internal rules of procedure - usually in connection with a desired change in the regime of job regulation.

\subsection{Unilateral or joint regulation, conflict and consensus}

Under capitalist conditions the possession of capital (to pay wages) and capital goods confers upon the owners or management the right to organize the process 


\section{Figure 6.2}

\section{The Industrial Relations Systems and the Regulation of the Employment Relation}

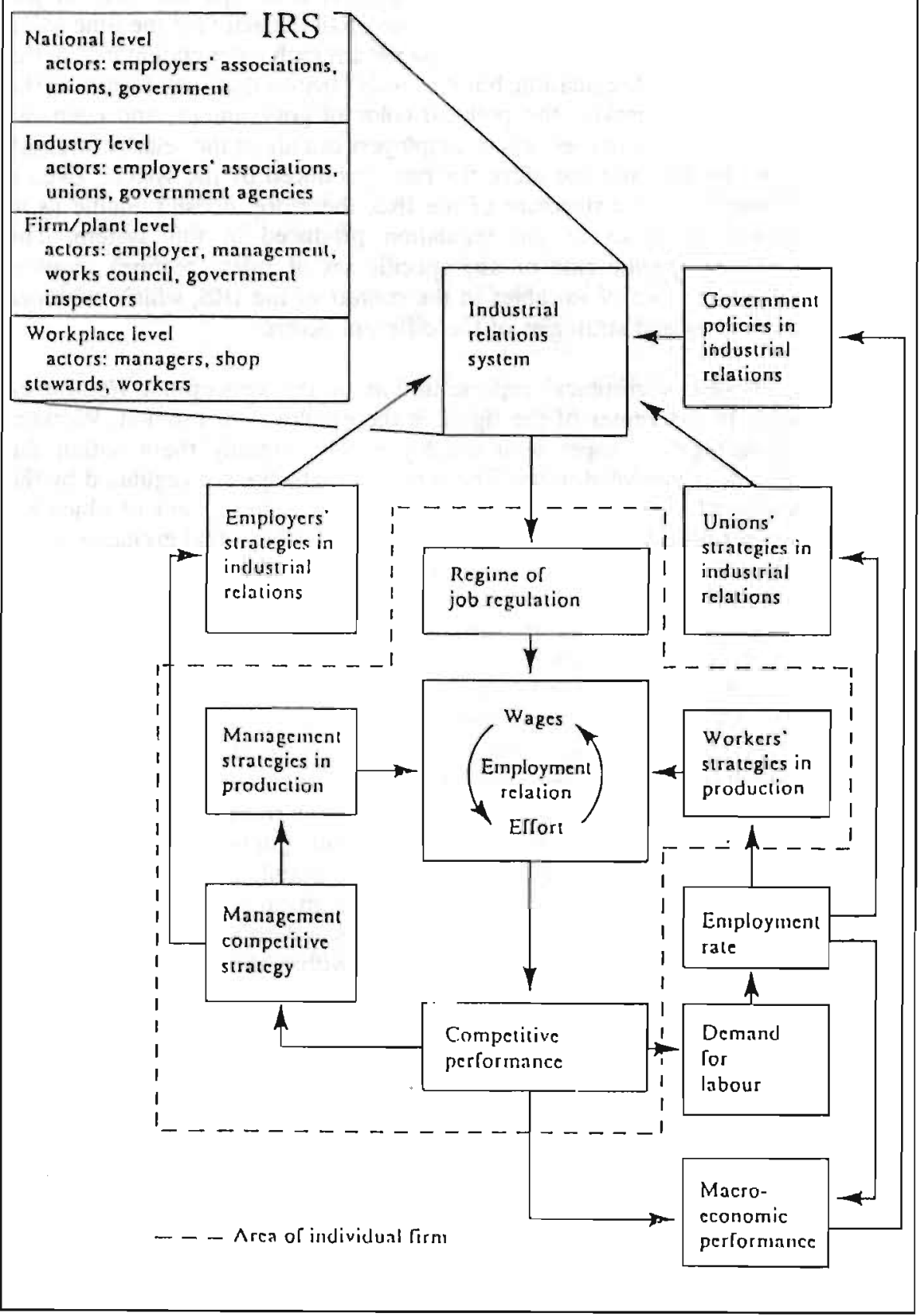


of production (including designing the jobs and planning the efforts of workers). The basic meaning of the labor contract under capitalist conditions is that the worker gives up his/her autonomy in exchange for a wage and allows the employer to decide what he or she has to do (heteronomy). Management therefore usually takes the initiative in designing rules and standards for the execution of jobs. As long as the workers do not object to the efforts demanded from them by management, the rules guiding the efforts side of the employment relation are simply rules made by management. Armstrong et al. (1981) express this quite strongly: "...the 'normal' mode of rule-making is by management decision, not by anything conventionally recognized as a bargaining process. (...) (R)ule-making hegins as a management process and (...) it becomes material for 'industrial relations' only as an 'exception' and by way of reaction to the background process of management rule-making." (64) It seems to me that Armstrong et al. are making an important point here, but they are going too far. It is correct to emphasize that management usually has the initiative in rule-making, but management is not operating in a vacuum: it cannot make rules at will. In the course of time many of the rules and standards developed by management have been challenged by the workers and have become an object of bargaining and conflict, some of it at the workplace, some of it more explicitly at higher levels of the industrial relations system. Collective agreements have been reached and in most countries, governments have enacted labor relations laws. As a result, there are limits to the rule-making rights of management, some of them imposed by government (the socalled status rights of employees), others agreed to after bargaining with unions or other representatives of the workers (the contractual rights of employees). A regime of job regulation will not prescribe behavior of the employer and employees in all detail; it will usually leave many things to be decided by the actual participants in the course of developing their relation. In practice, some actors may want to deviate from the rules and if they are not hindered to do so they may contribute to the creation of new rules (customs and practice). Here we find what amounts to a third kind of limitation on management's prerogatives: customary or informal rights of the workers, that are not based on any written agreement or formal law, but that are nonetheless very real and difficult to circumvent. Many of the employers' rights, however, have not been seriously questioned and in every employment relation there are many parts of the effort bargain that are virtually uncontested.

If we take a closer look at any regime of job regulation, we find that there are in fact always two kinds of rules making up a regime. On the one hand there are the rules that have been produced jointly by employers, workers and/or government. On the other hand there are rules that have been made by only one of the actors, without being contested by and without any explicit involvement of the other actors. Most of the unilateral rules come from employers as part of their efforts to organize production. These are usually the more specific rules for specific jobs, subject to the limits set by more general rules generated by the IRS as a whole. Of course, whatever decision an employer takes concerning job regulation, it will take the possible reactions of workers and their representatives into account. In that sense, any rule-making is a process of joint regulation and it is entirely correct to call the regime of job regulation a product of the industrial relations system.

It is important to see what the systems approach as outlined above does and does 
not do. What it does is to identify and describe the mechanisms behind a functioning employment relation. It argues that actors in the employment relation behave in accordance with certain rules and shows where these rules come from and under what circumstances they may change. It does not show, why actors might be willing to engage in regulatory activities and to stick to the rules thus produced. In fact, it is a basic assumption of the theory that all actors are willing to accept the employment relation as a fact of social life, that can and has to be regulated, but in its essence remains unchanged.

This basic assumption has earned the systems approach a lot of criticism. Because it took a fundamental aspect of capitalist society as given, the systems approach was accused of 'accepting' capitalist property and power relations. Moreover, these power relations were said to be presented in a distorted fashion: the notion of joint regulation seemed to suggest that the two parties in the employment relation were of equal stature, whereas in reality the employers are obviously more powerful (Fox 1974; Dimmock/Sethi 1986). Similarly, in his recent critique of Dunlop's systems approach, Roche (1986) says that Dunlop is assuming a 'value consensus' among workers and employers, which doesn't exist. In his interpretation of Dunlop, Roche distinguishes a minor and a major theory. The minor theory would refer to the position that "the features of a given set of contractual rules depend on the technological, market and power (by which Dunlop meant 'legal') situations of actors in industrial relations" (Roche 1986, p.8). The major theory would be that "rules are created in order to 'satisfy' the 'need' for order in industry" (idem, p.10). Roche considers the minor theory as more or less self-evident, whereas he criticizes the major theory, because it suggests a value consensus among the actors which does not exist and is not even necessary for the validity of the minor theory.

Let me use this critique of Dunlop for a further clarification of my conceptual framework (without indulging in the rather fruitless exercise of giving a 'correct' interpretation of Dunlop). Firstly, it is necessary to point out that the rules (the regime of job regulation) which are produced by the actors in the IRS cannot be explained only by factors ('situations') in the context of the system (which influence relative strength, perceptions of actors, etc.), but also by the actions and strategic choices of the actors, guided by the rules of the IRS, i.e. by the historical process of regulation. The IRS is not a mechanical device, which translates technological, market and power 'situations' into substantive rules, but a 'game' in which actors may or may not use the opportunities available to them to create rules in favor of their interests. Secondly, the rules (the regime) produced by the IRS can be expected to ensure some order in industry (in the production system). If they wouldn't do that, either the rules or the industry wouldn't survive very long. None of the actors may be completely satisfied by the prevailing order, and it is indeed doubtful that consensus can be reached about the properties of a desirable order in industry. Still, there may very well be a measure of consensus on the desirability of order as such, if that refers to a situation in which the industry and its employment relations continue to exist. In that sense, there is no great role in the IRS for actors who consistently prefer disorder over order in industry. This is the real meaning of the so-called consensus assumption: there is no alternative for the employment relation in sight and therefore all actors have an interest in its continuation. Interests diverge, however, as soon as the specifics of the relation - 
the terms of exchange - come into the picture. Thirdly, what I would consider to be a "major theory" would be a theory explaining the internal rules of the IRS, i.e. the structure of the system. Roche points out that Dunlop in his chapter 8 is trying to do just that and considers this to be a forgotten, but much more solid basis for general theory. Dunlop there tries to explain structural differences between national systems of industrial relations by reference to the historical process of political, economic and national cultural development. Contrary to what Roche seems to think, this explanation is nothing less than a special application of the two (the minor and the major) theories he identifies to a situation where an IRS has not yet been established - underlining the importance of the distinction between the rules of the IRS and the rules coming out of the IRS.

The structure of a national industrial relations system, i.e. the rules regulating the relations between the different actors in this system, has come into existence in order to satisfy industry's "need" for order in a specific phase of national political and economic development. A national IRS is first structured in the process of regulating specific employment relations probably during the period of national industrialization and is consequently influenced by the type of economic activities (dominant industry, state of technology) as well as by the characteristics of the political system of that period. This proposition is closely connected to the following:

1. Once an IRS has been structured, it is difficult to change the structure again, because it has meanwhile led to role definitions and identification with those roles; interests are interpreted and coalitions are formed on the basis of these roles and many participants consequently take an interest in preserving the structure as it is. 2. Major changes in the structure of the IRS can only be expected if there are also major structural changes going on in the economic, political or cultural context of the system. If the conditions and institutions that in the past assisted in structuring the IRS no longer exist, the forces in the IRS pushing for a continuation of that structure will be correspondingly weaker. This proposition doesn't exclude incremental change. Individual rules of the IRS may change, but the general structure - the outcome of the combined impact of all procedural rules on the roles of and relations between the actors - can be expected to remain relatively stable. 3. Structural change outside the IRS is a necessary, but not a sufficient condition for change in the structure of the IRS. In addition it is necessary that the IRS turns out to be incapable of producing a regime of job regulation that can adequately deal with problems arising out of the employment relation under the new economic and/or political circumstances (the 'need' for 'order').

\subsection{Technical change and the organization of work}

When actors are dissatisfied with the practices that eventually prevail in the employment relation, or rather with the results of these practices in terms of their goals (income, productivity), this will have repercussions on their activities in the industrial relations system. They may change their strategies, try to gain strength or to find allies in an effort to change the regime of job regulation or the procedural rules of the IRS or both. 
If performance of the firm is satisfactory, there will normally be little incentive for management to change the terms of exchange prevailing in the firm or more generally, to attack the regime of job regulation. In fact, efforts to change the rules may have direct negative effects on performance, if the new rules are opposed by workers and unions. However, if the firm is doing badly in a competitive market, it will consider changes in its mode of operation. Depending on what are considered the reasons for the bad performance, the rules governing the employment relation may come under attack. At first, management will try to achieve a better performance without changing the established rules. Control of workers will probably increase, as management tries to impose more vigorously its interpretation of the rules. If that is not enough, management will try to change the substantive rules of job regulation in the process of bargaining over wages, job evaluations, job descriptions, etc.. Eventually, all rules impinging on the utilization of workers and in some way limiting the freedom of management to act as it desires, will come under attack. The attack doesn't always succeed, however. Especially if there are other firms in the industry with a better performance, it is unlikely that an unsuccessful firm will be able to change the regime of job regulation beyond its own walls. Only the rules created in-house may come under pressure, but if workers have the possibility of moving to the more successful firms, even internally generated rules may remain unchanged. On the other hand, if a whole branch of industry is experiencing difficulties against foreign competitors, all actors in the industry's industrial relations system may be willing to participate in the construction of a new regime of job regulation. But again, if the industry is going down in an otherwise buoyant economy, employers may not be able to gather enough strength on their own, or to enlist support from other industries or government, in order to change more than the rules constructed within their own industry.

And even then, workers may prefer to leave the industry if they can, rather than agreeing to change the rules of job regulation. If on the other hand, employers in a wide variety of industries are facing economic problems and if they are also convinced that a change in the regimes of job regulation is a necessary part of their recovery strategies, workers and unions may have to agree to changes in the regime of job regulation, to which they would have been opposed in better days. If they do not agree or cooperate in such changes, employers and/or government may take the initiative in changing the whole structure of the industrial relations system, changing the rules of the game or even the identity of the unions with whom they are dealing. Thus, a general economic crisis and structural economic change may provoke initiatives for structural change in the industrial relations system, if the prevailing structure is not flexible enough to react to the new environment in terms of producing a regime of job regulation that enables firms to survive.

Of course, an economic downturn usually also changes the relations of forces between capital and labor. If firms go bankrupt and unemployment rises, the position of the workers and their unions weakens. This may result in changes in the regime of job regulation, especially in those parts of the regime that are revised regularly like the wage rates. Such changes, however, would normally remain within 
the limits defined by the structure of the industrial relations system. If changes in relative strength of the two parties would always result in structural changes in the IRS, the proposed conceptualization would be rather useless.

The relative performance of a firm depends on many other factors besides the terms of exchange in the employment relation. In manufacturing, efficiency and smoothness of production always depend on the ability and willingness of the employed to carry out the tasks assigned to them, but they depend also on many other factors: the availability of raw materials and intermediate products, the functioning of machinery and the presence of capable maintenance and repair personnel if machinery breaks down, the quality of parts and tools, the overall planning of the flow of production, etc.. Even if all of this has been taken care of, the firm may still perform dismally, if other firms have found cheaper ways of producing or have developed products that consumers find more attractive. It is the task of management to ensure that a firm is approaching current best practice in all parts of its operations - at least in terms of overall costs - and to develop marketable products.

If we look at the history of industrial production organization, workers' willingness to carry out their tasks was always considered to be an important management problem, but it was also seen as relatively easy to solve. On the one hand, wages and disciplinary action, carrots and the stick, were and are seen as the basic means of solving the willingness problem. On the other hand, it was always recognized that willingness can be enhanced by such job design that work becomes satisfying and meaningful to the worker. With the growing size and complexity of industrial production systems, the organization of all the other factors mentioned above became the main preoccupation of management. Regulating the employment relation became a function which often wasn't even represented at the highest management level of the enterprise. Wickham Skinner (1986) observes that a main assumption underlying the development and selection of equipment and process technologies has always been, that "otherwise successful and profitable equipment and production technologies may present personnel problems, but such problems can be overcome." (p. 161) In other words: labor power is traditionally considered to be the most flexible and most adaptable part of the production system: after technology has been chosen, workers and work organization can somehow always be added on later. It is therefore understandable that many analysts and also management itself have tended to look at technology, at the hardware, as a determinant of work organization, the division of labor and all other rules that management tries to impose in the employment relation. Recent research in this field, however, has come to emphasize that technology does not determine job design or work organization. Even if technology is taken as given, even if machinery is already in place, there are still options available for the organization of work and the design of jobs. The range of choice is of course even greater, if work organization is taken into account at earlier stages of the development of production technology. All this implies, that one type of production technology can be made to work profitably with different regimes of job regulation. Apparently, here lies a potential terrain of contest and of bargaining between employers and workers. This is more than the on-the-job bargaining we considered above, which 
is concerned with the intensity of effort required on a given job. Here we are also talking about bargaining about the (re)design of jobs, taking place for instance in talks between works councils and management on the occasion of a new investment project or between unions and employers' associations concerning the contents and organization of occupational training. Of course, such bargaining would remain of limited importance, if the various potential types of work organization showed large differences in productivity and profitability. In that case, economic mechanisms would ensure the eventual selection of the most profitable. In fact, international comparisons show that different types of work organization with clear differences in the quality of work coexist for an extended period of time, apparently without a clear relation to the relative performance of the firms concerned. This discussion becomes further complicated if dynamic arguments are introduced, for instance that it is advantageous to choose a less profitable type of work organization now, because it has a greater potential for further development than others that would be more profitable in the short run.

Such debate and the research based on it have a tendency to move away very quickly from the old viewpoint that technology basically determines work organization and job design, i.e. major parts of the regime of job regulation. A cautious remark therefore seems appropriate (see also Wood 1987). Technology provides options, but the range of options is not unlimited. It is probably more appropriate to say that a specific type of equipment and production technology determines the outer limits of the 'terrain of contest', i.e. of the possibilities for job design and work organization. If this is true, major changes in production technology, whatever their precise cause, will redefine the field of options concerning work organization and job design. Such changes will then quite often lead to management initiatives for changes in the regime of job regulation along with the introduction of the new technologies. As noted above, such initiatives often come as an afterthought after new equipment has been chosen. New machinery is often approved because it eliminates labor and it is then left up to lower management levels to propose a new work organization for the remaining workers, on the assumption that this will always work out somehow (with curiously little attention for potential savings in this area of action). Only recently awareness has (again) been growing, that decisions on job design and work organization may have an important impact on a plant's performance, and 'human resource' management is becoming one of the key elements in strategic management, represented at enterprise board levels.

Technical change thus enters the employment relation mainly through management initiative. Technical change is usually associated with new products or new process equipment. From an economic point of view, however, technical change has a wider meaning, referring to any shift in an industry's best practice, regardless of any connection to new 'hardware'. A new organization of work requiring fewer workers for the operation of the same equipment, or one resulting in better quality with the same number of workers, are just as much technical change in this sense as the introduction of a new piece of machinery.

The introduction of new techniques is part of a competitive strategy which reflects management's interpretation of the environment in which the firm is operating. In 
the automobile industry for instance, the interpretation of the successes of the Japanese producers has touched almost all dimensions of the production process over the past decade. New machinery (robots), new materials, new design methods (CAD), new models and new product features, but also new types of work organization, new job definitions, quality circles and just-in-time logistics have all been considered as contributing to these successes. The world's best practice, in other words, has changed fundamentally, not just in relation to hardware, but also to 'humanware'. Ultimately, therefore, any competitive strategy in the automobile industry will have to deal with questions of work organization and job design.

\subsection{Technical change and industrial relations in the auto industry}

Let us now return to the questions raised in the beginning of this paper. Since the early 1970 s the international automobile industry has been going through a process of crisis and change. Although this is a multifarious and complex process, two main elements can be easily distinguished: on the one hand there has been a sharp increase in competition because of the combination of stagnating demand and the appearance of several new independent producers from Japan (and recently from Korea) on the world market, who were able to produce at lower costs than their western competitors. On the other hand a wave of new technological opportunities has swept over the industry, changing the product as well as the production process. The new producers, moreover, turned out to be well posed to adopt these new technologies. In the organization of their manufacturing operations, the Japanese car manufacturers had adopted some of the main features of the western 'Fordist' production concept, notably the assembly line, but in several areas they had developed a different approach to work organization, with less distinction between direct and indirect work, more teamwork and more attention for the potential contribution to quality and efficiency by production workers. This made their production organization more flexible and more receptive for new process and product technologies. The interaction between these two elements, between the more quantitative and the qualitative aspects of the crisis, has complicated strategic decision making for all firms. The implications for management's policies toward work organization and the employment relation have been equally complex and sometimes even contradictory. Some aspects of the crisis, especially the combined arrival of stagnating demand and new low-cost producers, seemed to point to straightforward rationalization policies, mechanization and automation, shedding of overcapacities, dismissals and tough wage policies. Other aspects, like the renewed emphasis on design and quality, and the new models of work organization and industrial relations presented by the Japanese industry, seemed to call for a more encompassing policy of 'modernization', emphasizing not just product and process renewal, but also a better use of 'human resources', training and retaining personnel, motivating workers to take an interest in product quality, etc.. It is in the introduction of new techniques that both kinds of policies overlap. For instance, if robots are introduced in the body shop, not only will they replace a large number of welders, but the tasks of the workers on the new line will have to be (re)defined. (Dankbaar 1988) 
In fact, all automobile manufacturers in North America and Europe had to combine cost-cutting measures with efforts at 'human resource management', but the combinations were different in different countries, depending (among other things) on industrial relations. In an admittedly very rough generalization, it may be said that the prevailing regime of job regulation as well as the structure of the IRS in West Germany encouraged managements from the start to introduce new techniques in a 'modernization mode', emphasizing the reorganization of work and the utilization of human skills rather than the elimination of workers. In the USA and Great Britain on the other hand, managements found it more attractive, at least originally, to introduce the new techniques in a 'rationalization mode', emphasizing the cost-effectiveness of new technologies. eliminating workers where possible.

In Great Britain and the USA, the prevailing regime of job regulation tied workers' rights and rewards closely to the existing 'Fordist' system of work organization. In the USA for instance, job security depended on seniority, which was tied to a carefully defined system of job classifications. In Great Britain too, job descriptions were closely tied to manning levels, with the additional complication, that workers with different jobs were often represented by different unions. Using new technologies in a 'modernization mode', redefining jobs and the division of labor between direct and indirect, skilled and semi-skilled work, would involve major changes in the regimes of job regulation that had been produced in years of collective bargaining. In West Germany on the contrary, job security and wages were not based on this 'job control' approach. Consequently, workers and unions had less reason to consider management's initiatives concerning work organization as a direct attack on their positions. The changes in work organization that management considered necessary, could either be introduced unilaterally or formally agreed to without much upheaval through the existing bargaining mechanisms. In this respect, the West German industrial relations system turned out to be more flexible than the British or American system. Streeck (1986 a,b) has pointed out that somewhat paradoxically this flexibility arises from a system with a strong, formalized structure in which state legislation (co-determination) plays an important role. Clearly then, the IRS, its structure and the regime of job regulation arising from it, influenced the direction that work organization was taking in each country, confirming the relation (1) in our figure 6.1.

In the course of time, car manufacturers in the USA and Great Britain found out that cost cutting, dismissals, mechanization, automation and reassertion of management prerogatives were necessary, but not sufficient elements of a revitalizing strategy in the car industry. They had to 'modernize' and modernization implied a departure from the Fordist patterns of work organization. Modernization, 'learning from Japan', now meant a new approach to the combination of hardware and 'humanware'. Even automation had become a different affair: flexible automation took the place of single-purpose mechanization and required a different work organization, new training and new attitudes. Thus, eventually American and British manufacturers had to face the problem that a thorough modernization of their operations called for a major change in their regimes of job regulation. Here the two countries show different patterns. In the US, car manufacturers negotiated 
with the United Auto Workers (UAW) and achieved major changes in the regime of job regulation (wage concessions, a major reduction in the number of job classifications). In Great Britain, management unilaterally imposed major changes in the regime of job regulation, insisting on management prerogatives in a whole series of issues, and introduced changes in the structure of the industrial relations system with support from the government (new rules for picketing, strike ballots, union elections). In the new Nissan plant, even the traditional representation of different trades by different unions has been replaced by a single union approach. The relations between work organization and the industrial relations system in the process of introducing new production techniques in the car industry around 1980 can then be summarized as follows:

1. The prevailing regime of job regulation determined in the early stages the 'mode of introduction': rationalization or modernization.

2. Eventually, because of competitive pressures, all firms had to switch to a 'modernization mode' and the structure of the IRS determined whether it was possible to achieve a corresponding new regime of job regulation (where necessary) through regular bargaining or through unilateral action by management. 3. The unilateral imposition of a new regime of job regulation automatically implied management initiatives, with and without government support, to change the structure of the industrial relations system.

Table 6.1

Rationalization, Modernization and Industrial Relations in the Car Industry in West Germany, USA and Great Britain around 1980

\begin{tabular}{|c|c|c|c|}
\hline & West Germany & USA & Great Britain \\
\hline Rationalization & $\begin{array}{l}\text { Difficult under } \\
\text { prevailing regime }\end{array}$ & $\begin{array}{l}\text { Easy under } \\
\text { prevailing regime }\end{array}$ & $\begin{array}{l}\text { Easy under } \\
\text { prevailing regime }\end{array}$ \\
\hline Modernization & $\begin{array}{l}\text { Minor regime } \\
\text { changes necessary }\end{array}$ & $\begin{array}{l}\text { Major regime } \\
\text { changes necessary }\end{array}$ & $\begin{array}{l}\text { Major regime } \\
\text { changes } \\
\text { necessary }\end{array}$ \\
\hline $\begin{array}{l}\text { Structure of the IRS } \\
\text { after modernization }\end{array}$ & $\begin{array}{l}\text { Virtually } \\
\text { unchanged }\end{array}$ & Minor changes & Major changes \\
\hline
\end{tabular}

Table 6.1 provides a schematic summary of the (schematic) argument. In terms of our theoretical model, we find that British and US manufacturers, under the pressure of continuing unsatisfactory performance, have come to the conclusion that a new type of work organization is necessary, that cannot be realized under the prevailing regime of job regulation. Consequently, they have taken the initiative to put pressure on the unions and/or government to change the regime. In the UK this eventually led to some structural changes in the IRS. Here we see, how management's definition of the optimal work organization becomes a force influencing and changing the IRS, i.e. relation (2) in figure 1 . The question now rises, which one of these two relations identified in figure 1 is more important. Is it exceptional for the IRS to adapt to new practices in work organization, as now seems to happen in the US and Great Britain? Or is it exceptional, that an IRS can survive virtually unchanged and regulate employment relations in a rapidly 
changing environment, as seems to happen in Germany? Current analyses suggest a little bit of both. The changes in management's production concepts, that currently can be observed, are often considered to be exceptional, related to a new basic technology and representing a rare historical event (a 'divide') as suggested by analysts like Piore and Sabel (1984), Kern and Schumann (1984). In such cases, one would expect that changes in production technology and work organization give rise to changes in the IRS and in the regime of job regulation, unless an IRS is exceptionally flexible. That seems to be the point made by Streeck, who puts up the German/Scandinavian system as a model of flexibility for other countries. Lega] (status) rights of employees, enforced by the state, make it easier for workers and unions in these countries to negotiate about changes in the regime of job regulation, even in periods of high unemployment. The absence of such status rights for workers, especially in the field of co-determination, seems to have caused at least initially major competitive disadvantages for the car manufacturers in Great Britain and the USA. However, to the extent that modernization is more or less completed in all countries, a more 'normal' situation is developing, where job regulation is taking place within the framework of an established (restructured) IRS. Competitive pressure is still very high in the world car industry and the West German producers are being forced to undertake rationalization measures. It remains to be seen, if the German system is also flexible enough to deal smoothly with quantitative adjustment, that could largely be avoided so far (especially at the German-owned manufacturers) by early modernization and by going up-market. This will not be easy, especially if the reduction of personnel cannot be achieved on a voluntary basis (a major element of the German regime of job regulation), but the firms may find it advantageous that rationalization is taking place on the basis of a modernized production process, after many of the difficulties with new technologies that have bothered the car manufacturers in the other two countries, have been straightened out. 


\title{
7. Problems and Prospects of the West German Automotive Components Industry ${ }^{1}$
}

\author{
7.1 The West German car industry \\ 7.2 The West European automotive supplier industry \\ 7.3 The West German automotive supplier industry \\ 7.4 Changes in the market for automotive components \\ floor space \\ personnel costs \\ inventories \\ new technologies, new entrants \\ enterprise politics \\ 7.5 Implications for the supplier industry
}

It is only 20 years ago, that almost the entire world automobile industry stood in awe before the level of vertical integration achieved by General Motors. Its ability to produce even the steel and glass it needed in-house was considered one of the main reasons for its dominating position in the world market. Nowadays, that same high level of integration is seen as one of the liabilities that GM has to overcome in order to regain its balance in an industry where the old rules and models of operation no longer seem to count. All major car manufacturers in the Western World are presently following the lead of their successful Japanese competitors: they are reducing their level of vertical integration, reconsidering make-or-buy decisions that were made long ago, and building new, much closer relationships with their suppliers.

This paper explores the implications of recent outsourcing strategies of car manufacturers for the West German automotive supplier industry. After a brief analysis of the West German car industry in section 1, sections 2 and 3 provide some basic information on size and structure of the automotive supplier industry in Europe and West Germany respectively. Section 4 describes the tendency for de-integration in the West German car industry, investigates various motives for de-integration and provides some specific examples of changing assembler-supplier relations in that country. Section 5 finally describes the consequences of these changes in the market for the structure of the West German supplier industry.

\footnotetext{
${ }^{1}$ A slightly edited version of this chapter was published in French in: Étienne de Banvillc \& JeanJacques Chanaron (1991), Vers un système automobile européen, Economica, Paris, pp. 43-72.
} 
The production of automobiles, both passenger cars and commercial vehicles, and of engines and components is an activity of vital importance to the West German industrial economy. More than $11 \%$ of the persons employed in manufacturing industry are working in this sector and about $15 \%$ of all manufacturing investment is carried out there. As in most other West European countries, the history of the West German automobile industry in the post Second World War period is one of almost uninterrupted growth until the early 70's. In fact, between 1950 and 1970, it was only in 1967 that total vehicle production fell clearly below the level of the preceding year. That year was the first major post-war recession year and a first sign that the years of reconstruction were definitely over.

Total vehicle production (cars and trucks) in West had Germany increased from 306,064 in 1950 to $3,842,247$ in 1970 . Already in 1954 vehicle production in West Germany had surpassed the French level of production and two years it also overtook the UK. Since then, West Germany has been the largest car producing country in Western Europe. For many years, only the United States was producing more vehicles than West Germany, but it was in that same crisis year 1967 that Japanese vehicle production first surpassed West German production. The Japanese industry never gave up that second place behind the US again (and indeed gained the first place in 1980). It was another sign of structural change that would affect the dynamics of the industry in the decades to come.

Following the 1973 oil crisis, 1974 was, of course, the second major year of recession for the West German auto industry. Motor vehicle production fell by more than $20 \%$, from 3.95 million to 3.10 million. Whereas it had taken the industry only one year after 1967 to recover from the recession, it took three years now before the 1973 production level was reached and surpassed again in 1977. Since then, the industry has been expanding slowly, but quite steadily. The second oil crisis has not had the same impact as the first (two years of lower production in the early eighties). In the second half of the 80 's, production has reached new, unprecedented heights in a very favorable West European market. Thus, whereas the 1980 level of production was only slightly above that of 1970 , in 1989 it was approximately 1 million units higher (figure 7.1). In the following we will concentrate on developments over the past two decades.

The history of crisis, recovery and growth between 1970 and 1990 is reflected in the development of employment in the industry (figure 7.2). The reflection is far from perfect, however. What we see is that employment usually falls or stabilizes (with a time lag), if production declines. Each time, however, recovery has been strong and employment has increased substantially over the period. In 1970, 582,664 persons were employed in the automobile industry (passenger cars, trucks and components). Ten years later their number had increased to 684,071 . Considering the fact that production in these two years was almost identical, this suggests that the industry was having productivity problems. Another ten years later, with production 1 million vehicles higher, employment has again increased by approximately 100,000 . Of course, behind these global figures there are 
Flgure 7.1

\section{German Motor Vehlcle Industry \\ Production 1970-1989}

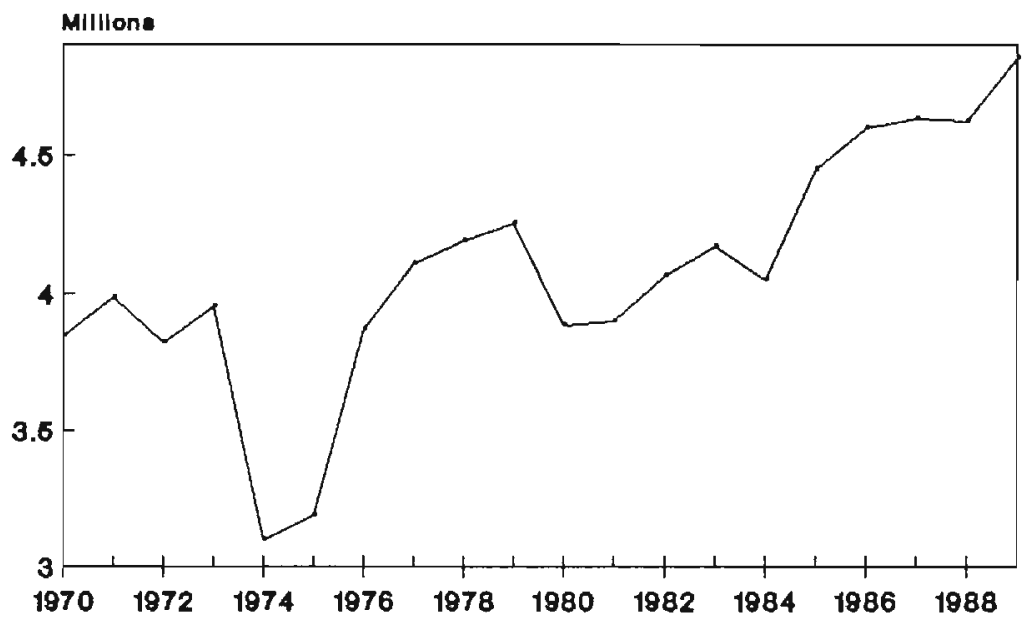

\section{Source: VDA}

differences between firms and between branches (motor vehicle producers vs. parts producers), on which we will comment below.

The West German motor vehicle industry encompasses basically six manufacturers (neglecting for the moment the very small ones). Four of these are German-owned enterprises: Volkswagen/Audi, BMW, Daimler-Benz and Porsche. The other two are subsidiaries of the major US manufacturers General Motors (Opel) and Ford. Three manufacturers are so-called volume producers of a range of passenger cars covering all major market segments. These are Opel, Ford and Volkswagen. Audi is part of Volkswagen and is especially aiming at the higher market segments. Volkswagen is the only one of the three German volume producers to have a special brand name for its luxury cars. The other three manufacturers are so-called specialty producers, aiming at the higher market segments only. Between them there are also important differences. Porsche is just a small producer of sports cars with an annual production volume of around 10,000 cars. BMW and Daimler Benz are major competitors of each other in the German market (and elsewhere), aiming at similar segments of the market, but whereas BMW is mainly a producer of cars and motor cycles, Daimler Benz has grown into a highly diversified industrial complex, the largest manufacturing enterprise of West Germany. Daimler is also the only German car manufacturer that is heavily engaged in the commercial vehicle market.

A large part of West German motor vehicle production has always been exported (figure 7.3). The share of exports in total production has been stable over the past 


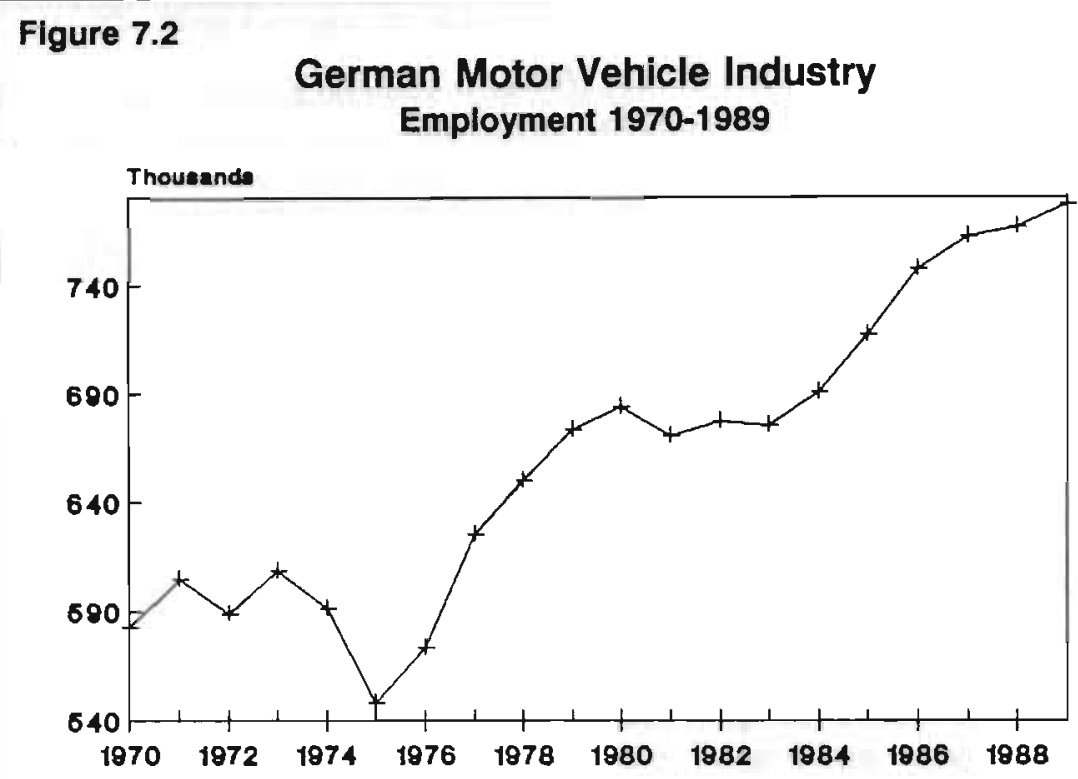

Source: VDA

two decades at approximately 55\%. The remaining $45 \%$ of production has guaranteed the German producers a dominating market share in their home market. For passenger cars, the share of West German producers over this period has ranged between $75 \%$ (in 1976) and 67\% (in 1986). Their share is slowly declining (and somewhat more than these figures indicate, because imports from foreign production operations are counted here as part of the 'German' share; the percentages given are based on registrations by brand name). Among the imports, Japanese brands have become increasingly important. Whereas the share of Japanese makes in total registrations of new passenger cars was little over $1 \%$ in 1970, it rose to $15 \%$ in 1987 (figure 7.4). From less than 3\% in 1970, Japanese imports now take up almost one third of total imports of passenger cars.

Imports of passenger cars have been growing faster than exports over the past two decades. The impact on the balance of payments has been less dramatic, because the value of the exported cars is much higher than the value of the imported cars. In the trade with Japan in 1988, for instance, for every five imported Japanese passenger cars sold in Germany, only one German car was sold in Japan. In terms of value, however, these exported cars $(85,000$ or $2.5 \%$ of the Japanese car market) amounted to $48 \%$ of the value of the Japanese cars imported into West Germany.

The Japanese manufacturers have clearly pushed down the market shares of other imported cars. However, if we look at the market shares of the individual German manufacturers, the market share of the five German-owned manufacturers 
Figure 7.3

\section{The German Motor Vehlcle Market}

(1970-1987)

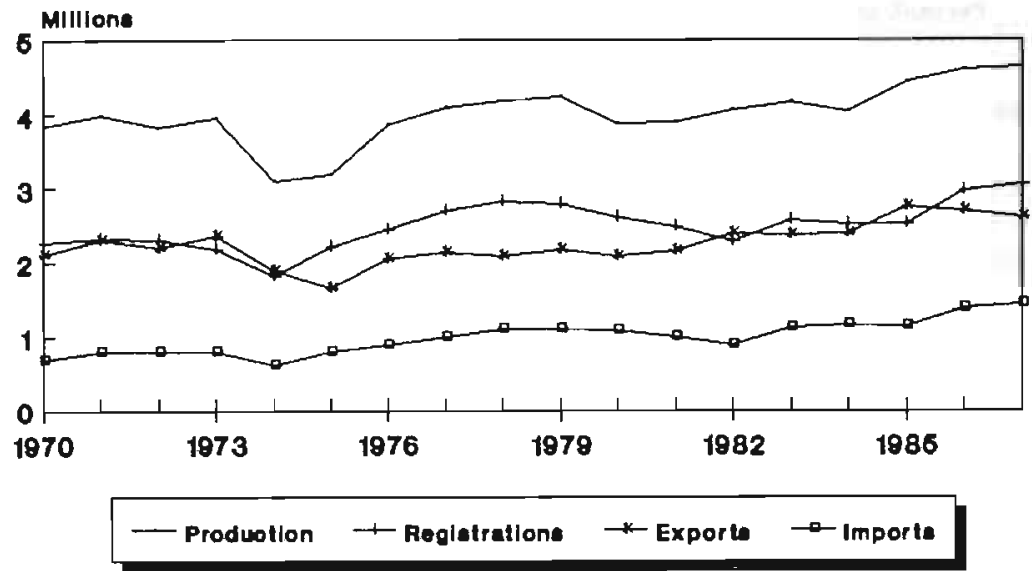

Source: VDA

(Volkswagen-Audi, Daimler Benz, BMW and Porsche) has been stable or even slightly increasing, whereas the share of the two US-owned manufacturers (GM/Opel and Ford) has been decreasing, especially that of Opel (figure 7.5).

In terms of profitability the German-owned producers also performed somewhat better over the last ten years than their American-owned counterparts. Audi, BMW, Daimler Benz and Porsche were profitable every year from 1980 to 1989. Volkswagen made a loss in 1983 only; Ford Werke AG incurred losses in 1980 and again in 1984 and 1985; and Adam Opel AG, finally, made losses in 1980 and ' 81 as well as in 1984, ' 85 and ' 86 . The profitability of the German producers is not very impressive, however, if it is set against turnover. Only in the second half of the eighties, when the market was booming, did the share of net profits in sales rise over the $2 \%$ mark.

The past two decades have been decades of crisis, rationalization and automation (for instance by the introduction of robots), but also of product innovation, a movement towards higher quality, safety and luxury. Whereas rationalization is expected to lead to lower employment, product innovation and improvement is expected to lead to growing numbers of workers in the car factories. If we consider the actual development of employment as the outcome of a struggle between these two contradictory forces, some interesting differences between the different manufacturers can be noted. Generally speaking, the German-owned manufacturers have been expanding their work force over the past decade, whereas the American-owned manufacturers have been contracting quite strongly since 
Figure 7.4

\section{Germany, Market shares}

1973-1987

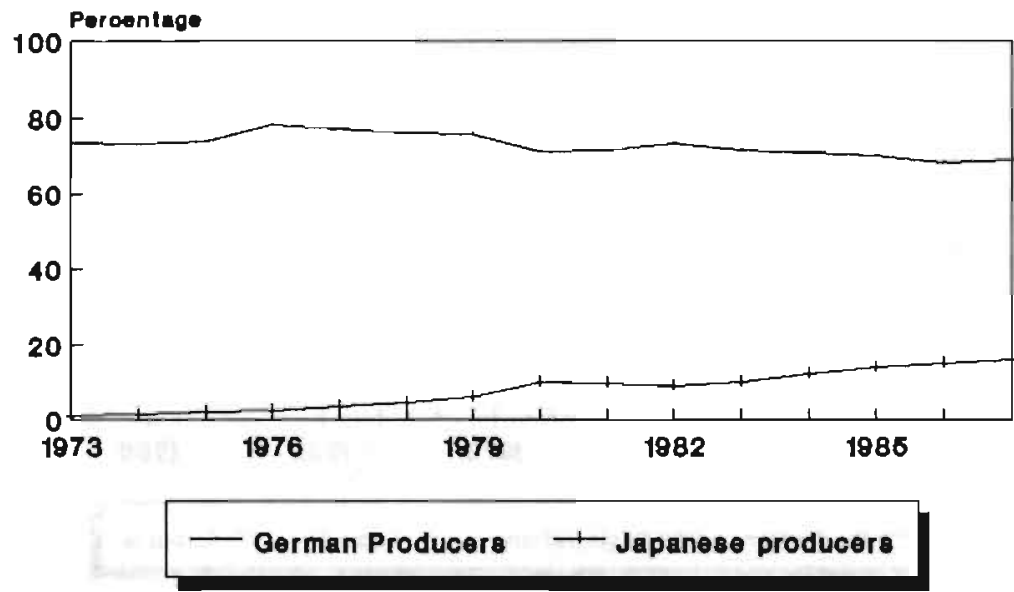

Source: VDA

1980. The result has been that employment at VW/Audi and Daimler Benz in 1987 was more than $20 \%$ above the 1978 level, and at BMW it was almost $50 \%$ higher. At Adam Opel AG and the Ford Werke AG on the other hand, the 1987 employment level was about $20 \%$ below the 1978 level. This would seem to imply that at these two firms rationalization had more weight than product innovation, whereas at the German-owned firms it was the other way around. In the last two or three years of the 1980's, however, employment at the German-owned manufacturers has also been contracting (at VW/Audi and Porsche) or stabilizing (at Daimler Benz and BMW). With new technologies and new models in place, rationalization gains the upper hand. This is all the more necessary as the German industry is feeling the pressures of an integrating European market, with a growing presence of the Japanese, but also of the Italian and French producers. Rationalization is basically following two courses of action. One is the improvement of productivity through increased automation and better work organization. The other is concentration on so-called core activities, an increase in outsourcing and co-operation with major components suppliers. We are concerned here with the latter strategy.

\subsection{The West European automotive supplier industry}

The European car manufacturers presently produce about 35 to $45 \%$ of the value of their products in-house, both by assembly activities and by manufacturing of several major components (apart from these activities, value is also added by 


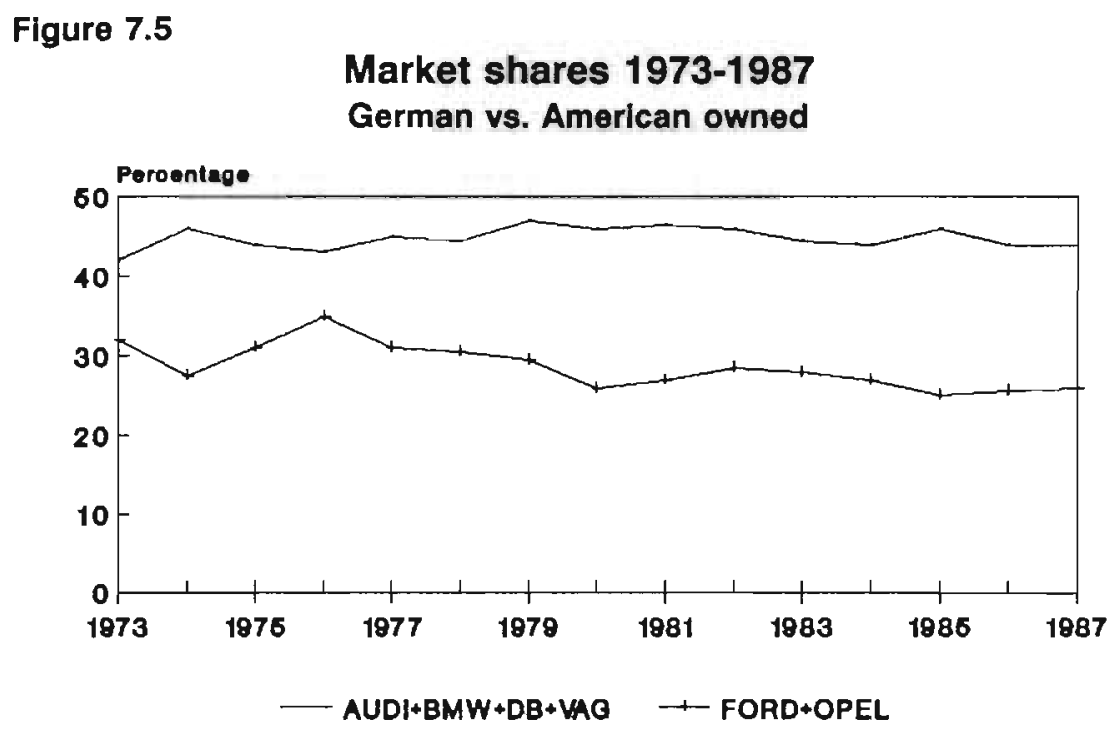

\section{Source: VDA}

distribution and marketing activities; the percentage mentioned refers to value added as a share of total sales value, see also Figure 7.6). The auto makers buy parts like tires, batteries and glass from suppliers, who usually also serve a large market for replacement parts (the so-called after-market). On the other hand, there are the so-called primary suppliers (the Original Equipment Manufacturers or OEMs) of proprietary and engineering components, who usually undertake considerable investments in R\&D to support their products. The secondary/tertiary suppliers are often subcontractors to the primary suppliers, but at least up till now they often also supply directly to the auto makers. This does not involve close interaction with the auto makers as in the case of the primary suppliers. Many of the parts they sell are not specific to the auto industry. Finally, there are the suppliers of materials, who often work closely with the vehicle manufacturers on questions of application and processing.

John Wormald (1989) distinguishes between in-house engineering and in-house manufacturing/assembly. Presently, he estimates that on average a European volume passenger car manufacturer is manufacturing $42 \%$ of vehicle value inhouse, but is responsible for the engineering of $60 \%$ of that value. "European vehicle manufacturers continue to exercise a substantial degree of direct design control over their products, particularly at the subsystem and assembly levels, sometimes providing detailed specification down to the level of components." (Wormald 1989, p.150) However, he expects this situation to change in the future, both with respect to engineering and to supply responsibility. Thus, by the year $200050 \%$ of total value of a car could be engineered jointly or independently by 
Figure 7.6

Shares of Retall Price of Car

\begin{tabular}{|l|l|l|l|l|l|}
\hline $\begin{array}{l}\text { External } \\
\text { Supply of } \\
\text { Parta and } \\
\text { Muterials }\end{array}$ & $\begin{array}{l}\text { Costs of } \\
\text { Trensportation } \\
\text { and Storage }\end{array}$ & $\begin{array}{l}\text { Vulue } \\
\text { Mdded } \\
\text { Maru- } \\
\text { facturing }\end{array}$ & $\begin{array}{l}\text { Costs of } \\
\text { Oistribution }\end{array}$ & $\begin{array}{l}\text { costs of } \\
\text { Morketing } \\
\text { and Soles }\end{array}$ & $\begin{array}{l}\text { Dealer } \\
\text { Margin }\end{array}$ \\
\hline
\end{tabular}

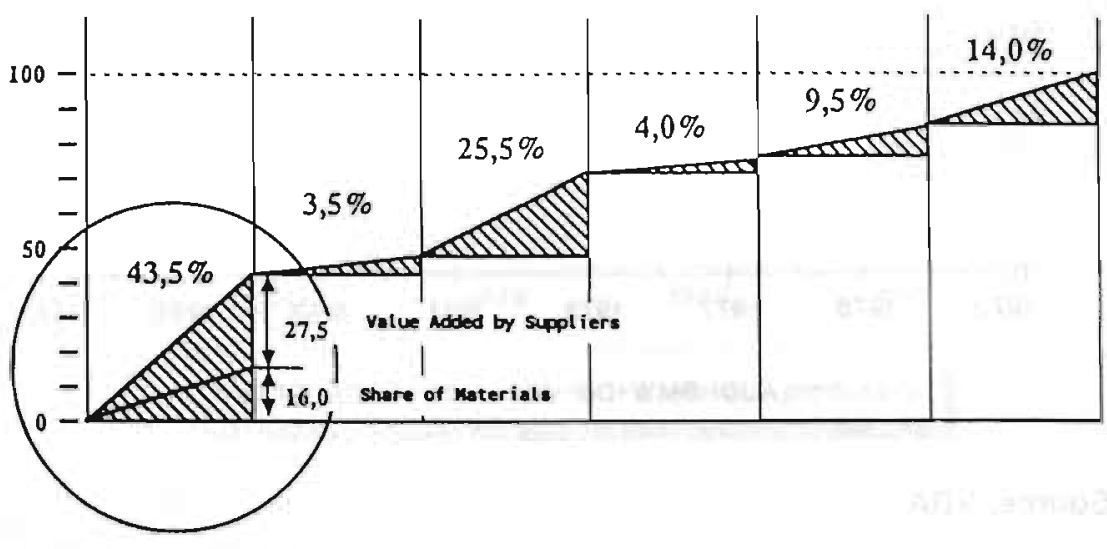

Source: Automobil Produktion, March (1988), p. 70

supplier firms, who by then would supply $63 \%$ of that value (Figure 7.7 ).

The European automotive supplier market is characterized by the fact that $80 \%$ or more of sourcing by the European car manufacturers is still nationally based. Apart from that, the car manufacturers have always tended to keep the supplier firms in highly dependent and subordinate positions. The result has been an industry composed of very few international firms (the main exception is Bosch) and a relatively large number of firms with a national orientation and a corresponding scale of operations that nowadays is considered clearly inefficient. Only recently, this situation is changing and several suppliers are consciously trying to establish European-wide or even global operations. The drive to reinforce scale and to acquire a better technology base is showing in the current high level of intercorporate transactions, like takeovers, mergers, joint ventures and alliances. These also reflect changing attitudes among the car manufacturers, who are now more ready to accept the need of financially and technologically strong supplier firms (however, European assemblers so far seem to be less inclined to transfer responsibility completely to suppliers than the US manufacturers: "In many cases, the European assembler is retaining development capability in a technology which could be comprehensively engineered by a supplier." (Lamming 1989, p.27)). 
Figure 7.7

In-house Manufacturing and Engineering as Share of Total Value, Europe 1990-2000

Europe 1990

SUPPLX

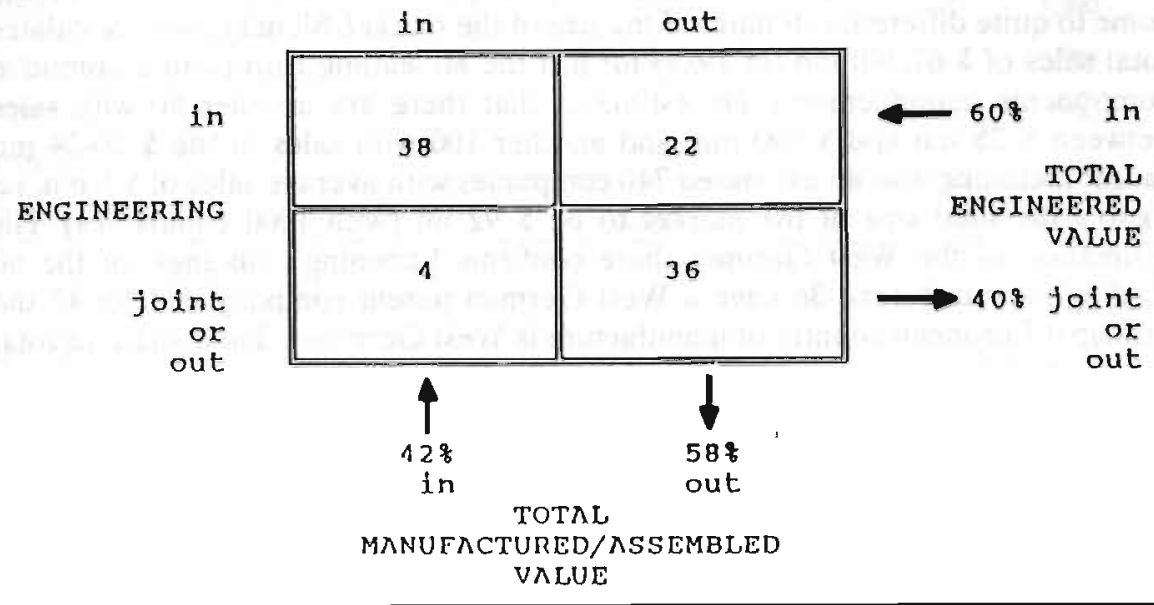

Europe 2000

SUPRLY

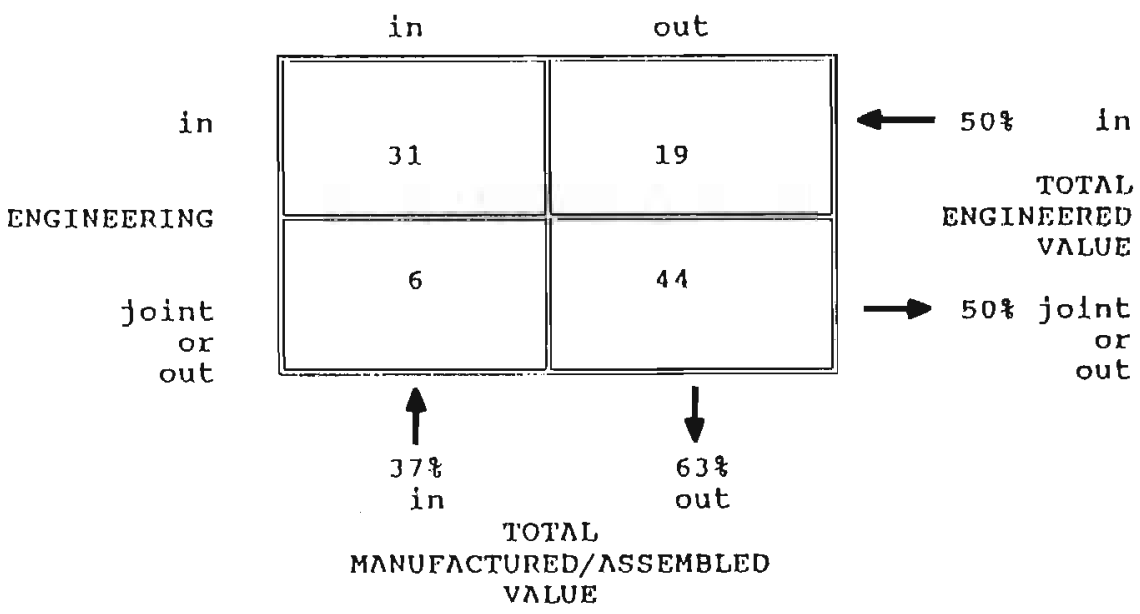

Source: Wormald (1989), pp. 151, 155 
Lamming estimates the size of the total European market to be about 50 bn ECU for original equipment and a further 20 bn ECU aftermarket (Lamming 1989, p.14; see also Table 7.1). He estimates that this market is served by approximately 10,000 minor and 1,500 major supplier firms: "the nationally based assemblers throughout the EEC buy between 85 and $97 \%$ of purchases in their home state, whilst major component suppliers realize about half their sales at home and a further third elsewhere in Europe". West Germany would account for $40 \%$ of the European components production, with 450 major and 5,000 minor firms. Others come to quite different estimates of the size of the market. Sleigh (1989) calculates total sales of $\$ 67,240 \mathrm{mn}$ (in 1987) for just the 80 leading European automotive components manufacturers. He estimates that there are another 80 with sales between $\$ 25 \mathrm{mn}$ and $\$ 500 \mathrm{mn}$, and another 100 with sales in the $\$ 10-24 \mathrm{mn}$ range. Including also an estimated 740 companies with average sales of $\$ 5 \mathrm{mn}$, he figures the total size of the market to be $\$ 92$ bn (with 1000 companies). His estimation of the West German share confirms Lamming's findings: of the 80 leading manufacturers, 36 have a West German parent company and for 43 the principal European country of manufacture is West Germany. Their share of total sales is $40.7 \%$.

\subsection{The West German automotive supplier industry}

Describing size and structure of the West German automotive supplier industry is not as easy as one might expect for an industry of this size. There is no separate organisation of automotive suppliers (the Association of the German Automobile Industry VDA covers car manufacturers as well as suppliers) and official statistics on 'Manufacture of Parts for Motor Vehicles and Motor Vehicle Engines' (SYPRO 3314) and 'Manufacture of Bodies for Motor Vehicles and of Motor Drawn Trailers and Caravans' (SYPRO 3316) cover only a fraction (mostly metal working firms) of all suppliers to the car manufacturers. Suppliers of tires, batteries, plastic parts and electronic parts for instance are not included in these categories. SYPRO 3314 (1987) provides a total count of 615 parts suppliers, employing 265,856 persons with total sales of DM 43.7 bn.. SYPRO 3316 (1987) adds another 363 firms with 37,786 employed and DM 6.6 bn sales. Including suppliers classified in other branches, other sources arrive at much higher figures. Table 7.2 shows estimates of the numbers of suppliers of original parts for the various German auto makers. These numbers can of course not be added because of double counting, but it is clear that there must be several thousand suppliers. One estimate speaks of 30,000 firms with an automotive turnover of approxiamtely DM 66 bn (AP June 1988: p.44). The number of suppliers who supply serial (in regular use for every car) parts and components, however, is much smaller. The Commerzbank (1987) mentions a total number of 2500 supplier firms. Doleschal (1989) arrives at a total of 3600 firms with approximately $1.5 \mathrm{mn}$ employees, of which 785,000 are dependent on sales to the car manufacturers. Total automotive sales of these 3600 companies amounted to DM 98 bn in 1988. 
Table 7.1

The Numbers of Automotive Components Firms in European Countries

\begin{tabular}{lcr}
\hline & Major & Minor \\
\hline West Germany & 450 & 5,000 \\
France & 400 & 1,500 \\
Italy & 250 & 1,000 \\
UK & 300 & 1,500 \\
Spain & 50 & 500 \\
Others & 50 & 500 \\
Total & 1,500 & 10,000 \\
\hline
\end{tabular}

Source: Lamming (1989), p.13

Table 7.2

Suppliers of serial components for the car industry

\begin{tabular}{lllllr}
\hline Firm & Suppliers & A- & B- & C-Parts & Units (1) \\
\hline & & & & & \\
Audi & ca. 1800 & - & - & - & 417.200 \\
BMW & ca. 1200 & $5 \%$ & $25 \%$ & $70 \%$ & 461.340 \\
DB & ca. 700 & - & - & - & 598.079 \\
Ford (2) & ca. 1440 & $16 \%$ & $12 \%$ & $72 \%$ & 837.603 \\
Opel (3) & ca. 1100 & - & - & - & 921.826 \\
Porsche & ca. 700 & $10 \%$ & $20 \%$ & $70 \%$ & 50.715 \\
Vw & ca. 2000 & $8 \%$ & $22 \%$ & $12 \%$ & 1.414 .734 \\
\hline
\end{tabular}

(1) Produced in 1987; (2) Of which 640 in West Germany, 690 in rest of Europe; (3) Appr. 90\% in Europe

Source: Doleschal (1989)

Parts of the supplier industry are highly concentrated. Doleschal and Bludau calculate that the largest 144 firms employ 856.000 persons and have a total sales volume of over DM 136 billion (Table 7.3). Half of these large firms (with over 1000 employees) can be found in the metal industry; the others are classified under the electrical, plastics, rubber, glass, textiles, paints, ceramics and chemical industries. It is often emphasized that the German supplier industry is typically medium-sized and not really prepared to face the competitive challenge of the large US and Japanese enterprises on the one hand and the new European conglomerates (Valeo, Magneti Marelli) on the other. On the other hand, as we will see below, the changes in the market have stimulated several new powerful actors to enter the scene, most notably Siemens. Table 7.4 provides names and some data for the most important West German automotive supplier firms. 
Table 73

A. Distribution of employment and sales in the largest German automotive supllier firms

\begin{tabular}{|c|c|c|c|}
\hline Firm Size & Number & Employees & Sales \\
\hline 10.000 u. grösser & 18 & 487.189 & 74.301 \\
\hline $5.000-9.999$ & 24 & 164.253 & 29.060 \\
\hline $3.000-4.999$ & 17 & 68.226 & 14.953 \\
\hline $2.000-2.999$ & 19 & 47.400 & 6.175 \\
\hline $1.000-1.999$ & 66 & 88.656 & 12.015 \\
\hline Totals & 144 & 855.724 & 136.50 \\
\hline
\end{tabular}

B. Branch structure of the largest German automotive supplier firms

\begin{tabular}{lrrrrrrrrrr}
\hline \multicolumn{1}{c}{ Size } & MET & ELE & PLA & RUB & GLA & TEX & PAI & CER & CHE & Total \\
\hline $10-30000$ & 9 & 6 & 2 & 1 & - & - & - & - & - & 18 \\
5- 9999 & 12 & 4 & 4 & 3 & 1 & - & - & - & - & 24 \\
$3-4999$ & 9 & 2 & 2 & 3 & 1 & - & - & - & - & 17 \\
$2-2999$ & 9 & 1 & 3 & 1 & - & - & 2 & 1 & 2 & 19 \\
$1-1999$ & 39 & 8 & 7 & 7 & 2 & 2 & - & - & 1 & 66 \\
\multicolumn{1}{c}{ Totals } & 78 & 21 & 18 & 15 & 4 & 2 & 2 & 1 & 3 & 144 \\
\hline
\end{tabular}

Source: Bludau/Doleschal

Table 7.4

West Germany's leading component manufacturers : classification by sales turnover.

\begin{tabular}{lrlc}
\hline Company & $\begin{array}{r}\text { Sales } \\
(\$ \mathrm{mn})\end{array}$ & Parent & $\begin{array}{c}\text { Country of } \\
\text { Parent }^{1}\end{array}$ \\
\hline Bosch & 7,611 & Robert Bosch GmbH & \\
ZF & 1,942 & Zahnradfabrik & \\
Continental & & Friedrichshafen AG & \\
BASF & 1,772 & Continental AG & \\
Teves & 1,667 & BASF AG & USA \\
Mahle & 1,306 & ITT Inc & \\
VDO & 861 & Mahle GmbH & UK \\
Uni-Cardan & 859 & VDO Adolf Schindling AG & \\
Behr & 795 & GKN plc & \\
Freudenberg & 770 & Behr GmbH & \\
Fichtel \& Sachs & 607 & Carl Freudenberg GmbH & \\
Hella & 602 & Mannesmann AG & \\
Siemens & 600 & Rheinhold Poersch GmbH &
\end{tabular}


Table 7.4

West Germany's leading component manufacturers : classification by sales turnover.

\begin{tabular}{|c|c|c|c|}
\hline Company & $\begin{array}{r}\text { Sales } \\
(\$ \mathrm{mn})\end{array}$ & Parent & $\begin{array}{l}\text { Country of } \\
\text { Parent }\end{array}$ \\
\hline Du Pont & 600 & Du Pont de Nemours \& Co & USA \\
\hline SWF & 483 & ITT Inc & USA \\
\hline SP Reifenwerke & 441 & Sumitomo & Japan \\
\hline Mann Filter & 417 & Mann \& Hummel GmbH & \\
\hline Webasto & 401 & Webasto AG & \\
\hline Eberspächer & 397 & Eberspächer KG & \\
\hline Varta & 397 & Varta AG & \\
\hline Happich & 389 & Happich GmbH & \\
\hline Boge & 322 & Boge AG & \\
\hline Kolbenschmidt & 322 & Kolbenschmidt AG & \\
\hline Ymos & 286 & $Y \operatorname{mos} A G$ & \\
\hline Phoenix & 284 & Phoenix AG & \\
\hline Goetze & 281 & Goetze AG & \\
\hline Kostal & 222 & Leopold Kostal GmbH & \\
\hline Pierburg & 214 & Pierburg GmbH & \\
\hline Voith & 208 & JM Voith GmbH & \\
\hline RHW & 183 & RHW GmbH & \\
\hline Flachglas & 179 & Pilkington plc & UK \\
\hline LUK & 172 & LUK GmbH & \\
\hline Mannesmann Kronprinz & 167 & Mannesmann AG & \\
\hline KKK & 161 & MUT/Daimler-Benz AG & \\
\hline Halbergerhütte & 153 & Halbergerhütte $\mathrm{GmbH}$ & \\
\hline Elring & 112 & Elring Dichtungswerke GmbH & \\
\hline Knorr-Bremse & 100 & Knorr-Bremse AG & \\
\hline Desag & 97 & Desag GmbH & \\
\hline Moto Meter & 88 & Moto Meter AG & \\
\hline Kaco & 75 & Kaco GmbH & \\
\hline BBS & 74 & BBS AG & \\
\hline Perrot-Bremse & 67 & Fulminawerke $\mathrm{KG}$ & \\
\hline Aeroquip & 50 & Trinova Corp & \\
\hline
\end{tabular}

1. In case not West-Germany

Source: derived from Sleigh (1989), Table 3 (pp. 29-33).

\subsection{Changes in the market for automotive components}

Figure 7.8 gives an impression of current world-wide 'de-integration' trends. It shows that little change is expected in the fields of raw materials and rough processing, where a clear division of labour is in force. In finish processing and 
especially in components processing, however, manufacturers are expected to shift to external sources. A review by Booz, Allen \& Hamilton (1987) estimates that in the 1990 's, compared to the early 1980's, approximately $10 \%$ more of value added will be contracted out to the supplier industry.

Table 7.5

Vertical integration in the West German car industry added value divided by total value of production (\%)

\begin{tabular}{lccccccccc}
\hline & 1970 & 1978 & 1980 & 1982 & 1983 & 1984 & 1985 & 1986 & 1987 \\
\hline $\begin{array}{l}\text { Daimler Benz } \\
\text { AG }\end{array}$ & 41,7 & 47,4 & 45,2 & 43,4 & 43,7 & 43,9 & 44,4 & 46,9 & 46,3 \\
BMW AG & 39,5 & 45,6 & 42,4 & 40,2 & 40,0 & 40,9 & 39,7 & 36,6 & 35,7 \\
VW Konzern & 35,4 & 43,2 & 42,0 & 40,6 & 40,3 & 40,6 & 40,7 & 37,3 & 34,3 \\
Ford Werke & 36,2 & 42,2 & 35,1 & 35,4 & 34,1 & 30,5 & 29,9 & 31,8 & 32,9 \\
AG & & & & & & & & & \\
Adam Opel & 36,7 & 40,7 & 32,9 & 31,3 & 30,5 & 27,7 & 28,2 & 27,6 & 30,0 \\
AG & & & & & & & & & \\
Average & 37,6 & 44 & 41,3 & 39,7 & 39,2 & 39,0 & 39,0 & 38,3 & 37,2 \\
\hline
\end{tabular}

Source: IG Metall

The West German auto makers are all on the path of de-integration. Volkswagen has announced publicly, that it wants to reduce its level of vertical integration by one percentage point per year. Naturally, the West German metal workers union IG Metall is following these developments closely and it is from that source that data about the trends in vertical integration are regularly being made available. Table 7.5 shows that vertical integration reached a peak in 1978 and has been decreasing by about 10 percentage points for all manufacturers except Daimler Benz. Except for the latter firm, vertical integration has reached a level of $30-35 \%$ of the value of production. Other calculations sometimes come to different data, but the trend is undisputed: the car makers make less and less of the car themselves. A recent authoritative survey of opinions among leading managers in the automotive industry predicts a continuation of the historical trend at least until the mid 1990's (Figure 7.9).

Dimishing the level of vertical integration and concentration on 'core activities' has become something of a fad in many branches of industry. In all likelihood some of the outsourcing decisions that are now being taken will later be regretted and if possible reversed. Nevertheless, apart from management- and above all consultancy-fashions, there is also some more solid economic reasoning behind the trend of diminishing vertical integration. It is clearly related to other fundamental changes in the industry: changes in product technology (the increasing importance of electronics), changes in the market (increasing intensity of competition with high product differentiation and shorter product life cycles), changes in the production process (partly necessitated by the changed market conditions, but also driven by 
Figure 7.8

\section{Shifting sourcing strategies in the motor vehicle industry}

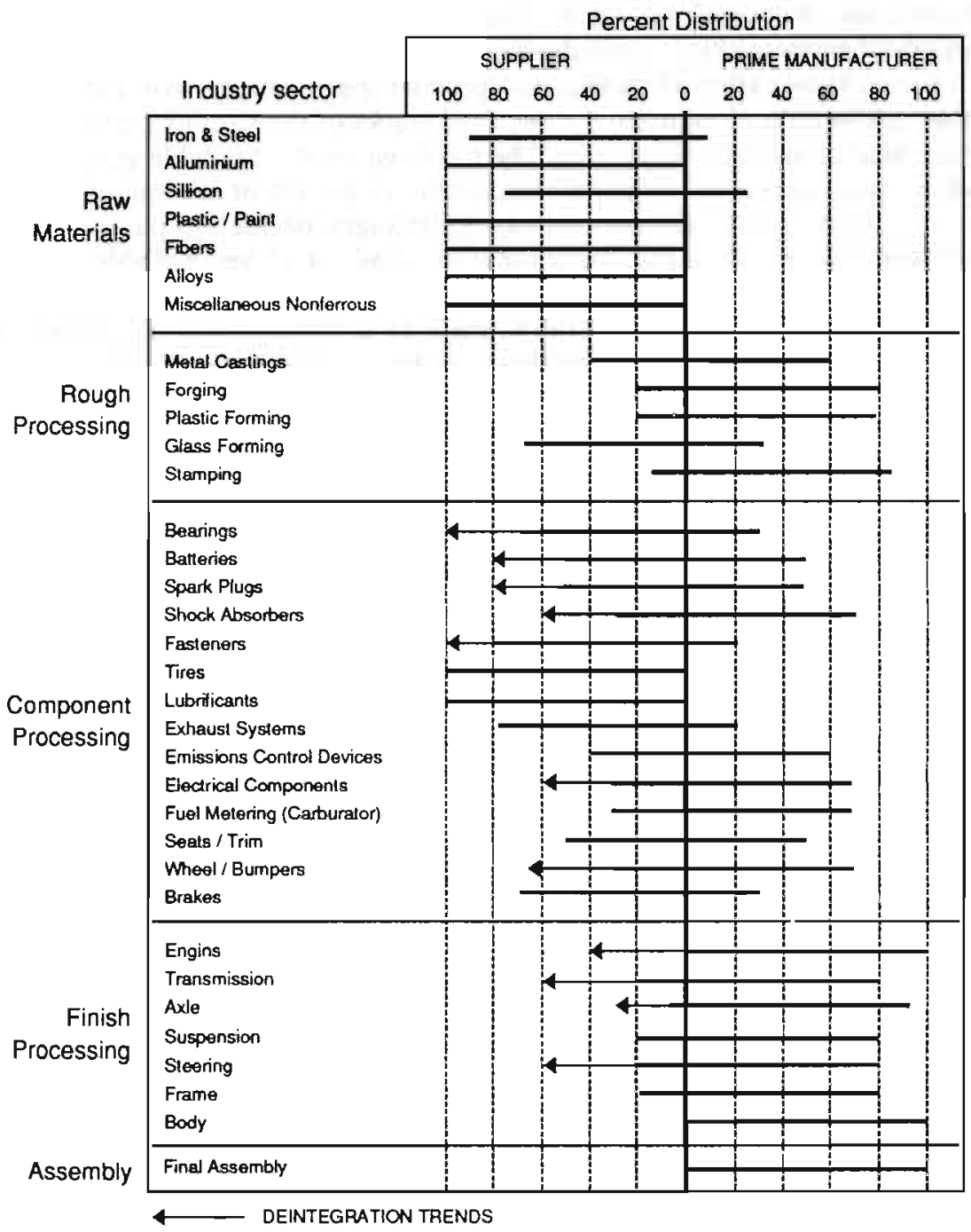

Source: Booz , Allen \& Hamilton 
new technological possibilities).

floor space

One reason for considering de-integration is the increasing lack of floor space in assembly plants, caused by new assembly techniques (the use of automated guided vehicles) and the break-up of the traditional assembly line, with the off-line assembly of major components and sub-assemblies. These changes are also induced by the increasing variety of models and product specifications. Without a change in the organisation of logistics, the required stocks of the various parts necessary for this kind of product variety would be too large for the available storage space. Lack of space makes it sometimes interesting to get rid of secondary activities. This is probably one of the reasons why Volkswagen decided to purchase plastic tanks from Kautex, after producing them in-house for 15 years. Table 7.6 shows expected changes in required floor space in a West German assembly plant for small commercial vehicles. All major production departments will need more square meters per vehicle, but assembly's needs are clearly becoming much higher with an increase of almost $60 \%$ (including pre-assembly activities). Clearly, if the erection of new buildings is impossible or too expensive, other production activities will have to move.

Table 7.6

Available and planned floor space in a German assembly plant (1988)

\begin{tabular}{lcc}
\hline Production Dept. & Present Space & Planned Space \\
\hline & (in square meter per vehicle) & \\
Press Shop & 28 & 37 \\
Body Shop & 69 & 80 \\
Paint Shop & 56 & 63 \\
Total Assembly & 112 & 178 \\
(Without Pre-Assembly & 65 & 108 ) \\
\hline
\end{tabular}

Source: Jürgens/Reuter

\section{personnel costs}

A second reason for de-integration is that parts suppliers can often make the same parts cheaper than the car manufacturer because of lower personnel costs. There are several reasons why personnel costs at parts suppliers might be lower than at the car manufacturers. Simply because of their size, because of their often more complex operations and the need to keep a strong research, development and engineering capability, the car manufacturers (and especially their parts supplying operations) suffer from large overhead costs and bureaucratic frictions. Besides that, depending on the industry in which the parts supplier is operating, differences in collective agreements may involve considerable wage differentials. A worker producing seats in a motor vehicle plant falls under the collective agreement for 
metal workers, but if the same work is done at an independent seat manufacturer, the relevant collective agreement may be that of the textile industry. Figure 7.10 shows that even the suppliers falling under the category of SYPRO 3314 (see above) have considerably lower personnel costs per employee than the car manufacturers. Capital costs per employee (depreciations plus interest paid on loans) are also higher for the motor vehicle manufacturers, which reflects a higher capital intensity. To the extent that more capital requires higher skilled work, this would explain the higher personnel costs. The crisis of the automobile industry in the first half of the eighties finds an interesting illustration in Figure 7.11, which shows that from 1980 to 1984 these higher costs per employee at the car manufacturers did not result in higher profits per employee. This must have given additional impetus to the outsourcing movement.

Of course, the question might be raised if suppliers from outside Germany might not be able to produce at even lower costs than the West German suppliers. Imports of motor vehicle parts into West Germany have been increasing steadily and are expected to increase further. Johannes Ricken of the supplier firm Kautex estimates that "if imported parts used to make up $8 \%$ of externally acquired parts for a car manufacturer only a couple of years ago, that percentage is bound to be around 15\% or higher by now" (AP June 1989, p.28). So far, however, local (national) content of the West German cars appears to be far over $80 \%$. Imports of parts have grown, but so have exports. The relation of exports to imports of parts and accessories of motor vehicles (measured in US dollars) has changed slightly from 3.21 in 1980 to 3.01 in 1985 and 2.88 in 1987 (Figure 7.12). Imports of parts not covered by the statistical category used here may have grown a little faster, but it seems safe to conclude that the international competitiveness of the West German automotive parts suppliers is still considerable, in spite of the high West German wages. In fact, West Germany has a positive balance of payments in automotive parts with all its European trade partners. Imports from so-called low wage countries have grown quite rapidly, but from a very low base, and there is no reason to expect that they will be able to balance the exports of parts from West Germany to non-OECD countries in the foreseeable future. It is, moreover, highly likely that a considerable share of automotive parts imports comes from foreign operations of West German suppliers. Doleschal estimates that at least $75 \%$ of the suppliers he has identified have either their own operations in foreign countries or have products produced under licence there. A survey of the suppliermembers of the VDA showed that they were producing in altogether 50 different countries and counted 623 fully or partly-owned subsidiaries and licencees.

Of course, this move is also necessitated by the movement of German assemblers to other countries, for instance to Spain. "The supplier who really believes that he can export his parts from here to Spain and to deliver them there just in time for assembly, will be in for some unpleasant surprises. No-one will buy that kind of delivery concept from him." (Ricken, June 1989, p.28) 


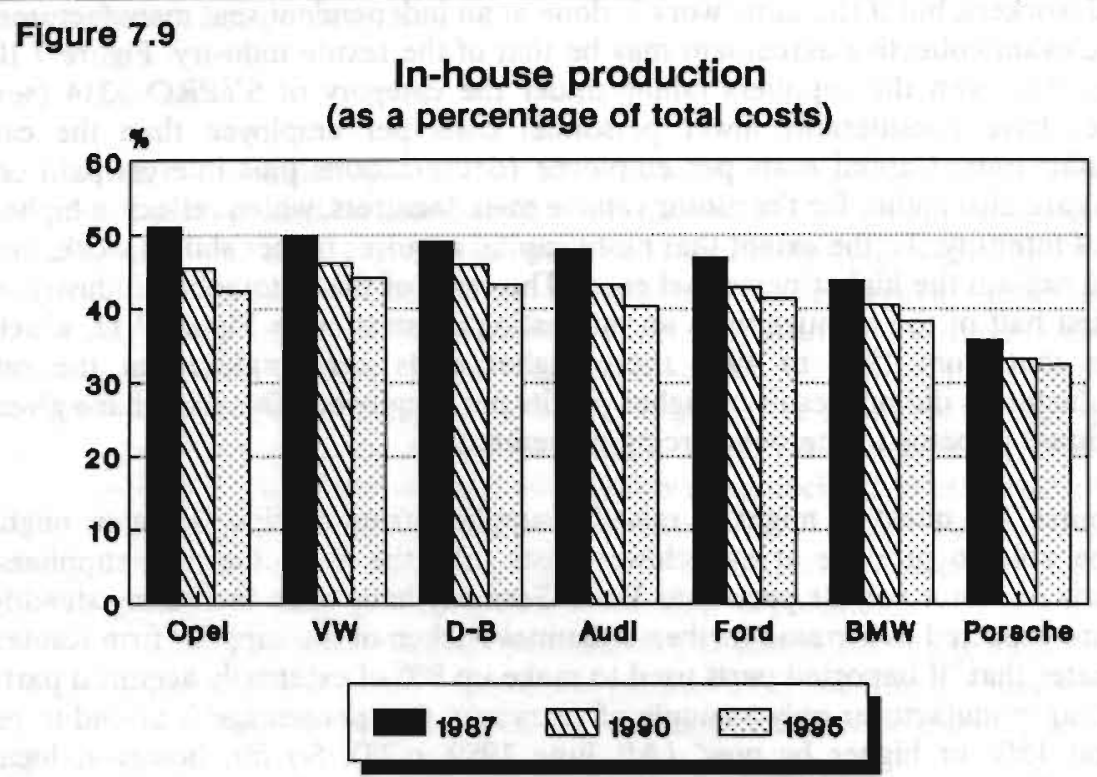

Source: Andersen/Wildemann 1988

\section{inventories}

A third reason for de-integration is that the costs of inventories of parts and goods in process have been given more and more attention, partly because of their increasing numbers with greater product variety, partly because of the increased efficiency elsewhere, which made the share of inventory costs in total costs go up. Of course, the Japanese methods for dealing with inventories (just-in-time delivery) have greatly influenced thinking in this field. Just-in-time production and just-intime delivery (the two are not the same!) have been on the increase in the West German motor vehicle industry, but if only for lack of clear definitions, it is difficult to measure how much has been achieved. Of course, not all parts are equally suitable for just-in-time procedures. In German business literature a distinction is made between A-, B- and C-parts according to value (high, medium, low) consumed per period and the related costs of tied capital involved. Only about $10 \%$ of all externally bought parts are considered A-parts (see also Table 7.2), but these represent a much higher share of the total value of externally supplied parts (up to 80\%). A further differentiation can be made between socalled X-, Y- and Z-parts, i.e. parts that are used at a constant rate, a regular cyclical rate and an irregular rate. Although this approach has been developed in relation to relatively simple parts, it can also be used to examine the JIT-suitability of more complex subassemblies and components like complete seats, panels, instrument panels, drive trains, etc. Although these systems often differ from one car to the next, they are used at a constant rate and the problem of dealing with the changing mix of components is no longer dealt with by the car assembler but 
by the systems supplier, who in turn can make an ABC-analysis of the parts he is using.

Available data show a strong growth of external data links for all auto makers. It can be safely assumed that all of the 144 larger supplier firms mentioned above have the capacity for data links both in the commercial and in the technical field. Volkswagen alone had EDI connections with about $10 \%$ of its 2,500 regular suppliers by the beginning of 1989 (AP April 1989, p.100). In 1988 Daimler Benz had EDI connections with 150 suppliers for the transfer of delivery calls. A considerable number of them is also connected to the CAD system of Daimler Benz. EDI-consultant Actis, specialized in the automotive supplier business lists 186 clients in West Germany (february 1990) that make use of its front-end-system. Interestingly, the German Association of the Automobile Industry (VDA Verband der Automobilindustrie) has been very active in the promotion of standards for the transmission of data. The VDA surface interface (VDAFS) was created in 1983 for the transmission of free form surfaces. It is especially geared to the requirements of surface systems as used in the automotive industry. VDAFS is increasingly being used also in other parts of Europe. VDA is also attempting to establish an overall system for the centralized preparation of standardized parts descriptions, which is flexible in terms of CAD. A first project entitled VDAPS (VDA Program Interface) is concerned with the exchange of standardized parts descriptions between different CAD systems. Furthermore, VDA has developed several standardized messages for EDI (delivery calls, invoices, shipping notifications, transport noticifications). These standardisation efforts show a clear awareness of the technological needs arising from the external integration of formally independent firms, like parts suppliers and car manufacturers.

Probably more than in the original Japanese 'kanban' example, just-in-time in Germany has a clear information technology content. This is especially so in the case of just-in-time production, where components are being produced exactly in the volume and sometimes even the sequence in which they are required at the assembly line. One example is the company Webasto, which is producing slide sunroofs at a volume of 7000 per day in two plants, serving practically all German car assemblers. In its Utting plant, it has optimized the internal and external logistics so that now $10 \%$ of the externally sourced parts (accounting for $70 \%$ of the value thereof) are delivered exactly on the day they are needed. Basically, this concerns sheet metal and electrical motors. Stocks of ready product can be found only on the trucks, that are on their way to the clients, who build them right away into their cars. A pilot project is going on to introduce EDI for the transfer of shipping notices, invoices and data on quality and construction (AP September 1989). Best known examples of just-in-time production are in the production of seats. Daimler Benz offers its customers a choice of 35,000 different seats (materials $\mathrm{x}$ colors $\mathrm{x}$ technical features). Since 1985 Keiper-Recarco is delivering complete sets of seats at the Daimler-Benz assembly line (now 600 per day), that have been ordered only 5.5 hours before. Production at Keiper-Recarco is automatically controlled by orders coming in over a direct data-link. There is no inventory of completed seats and the inventories of parts and raw materials at Keiper-Recarco has also been reduced to an average of 1.5 days of production. A similar system has been 
Figure 7.10

\section{A comparison of Cost Structures \\ Motor Vehicle Manuf. vs. Parts Manuf.}
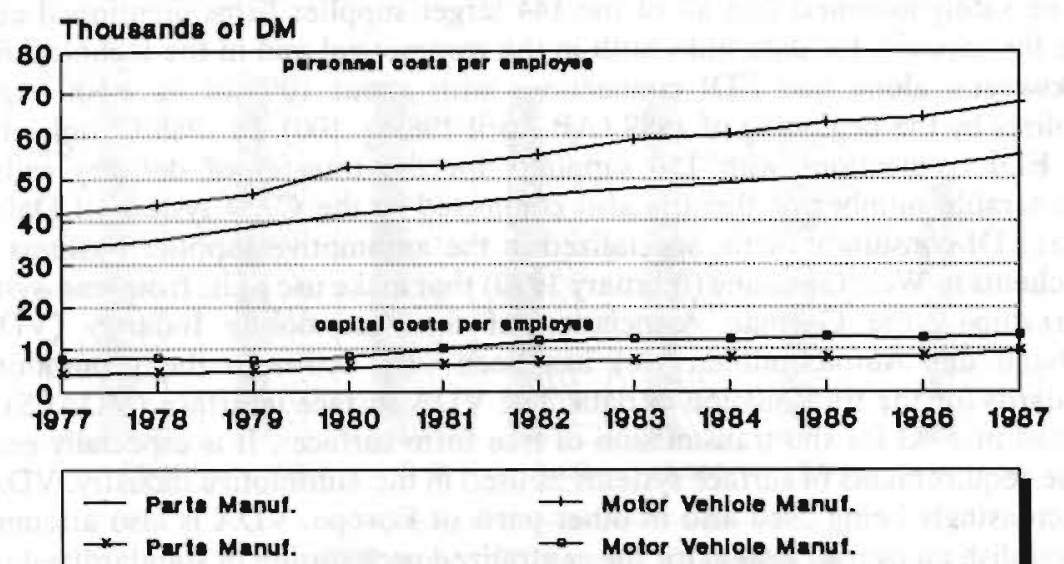

Source: Statistisches Bundesamt

introduced more recently by Schmitz \& Co, who are producing seats for the new BMW plant in Regensburg. Schmitz and Co receive the final production order via teleprocessing only two hours prior to fitment. Both the Keiper-Recarco and the Schmitz plant are new just-in-time plants especially built for this purpose at short distance from the final assembly plant. The building of the new BMW plant in Regensburg prompted 20 supliers with more than 2500 employees to set up new production sites in the vicinity.

Altogether it is estimated that there are today about 120 assembly plants of parts suppliers, that have been built especially for just-in-time production or delivery. It is difficult to come to a more precise count, because of the possibility that parts of older plants have been re-organized for just-in-time purposes.

Just-in-time delivery can of course be realized without just-in-time production and the consequent integration of the production control system with that of the car manufacturer. Just-in-time delivery can be done from inventory (but even in that case, the capability to fit into the vehicle maker's computerized manufacturing requirements program is usually required). If delivering from inventory, the supplier would be carrying the inventory costs that used to be carried by the car manufacturer. And indeed, we see among suppliers an increasing tendency to physically separate the activities of processing, assembly and storage, with the latter two being decentralized and moved in the vicinity of the car plants. Examples of just-in-time delivery at the new Volkswagen factory in Emden are the delivery of plastic tanks from a warehouse by Kautex and the delivery of bumpers 
Figure 7.11

\section{Profits per Employee}

Motor Vehicle Manut. vs. Parts Manuf.

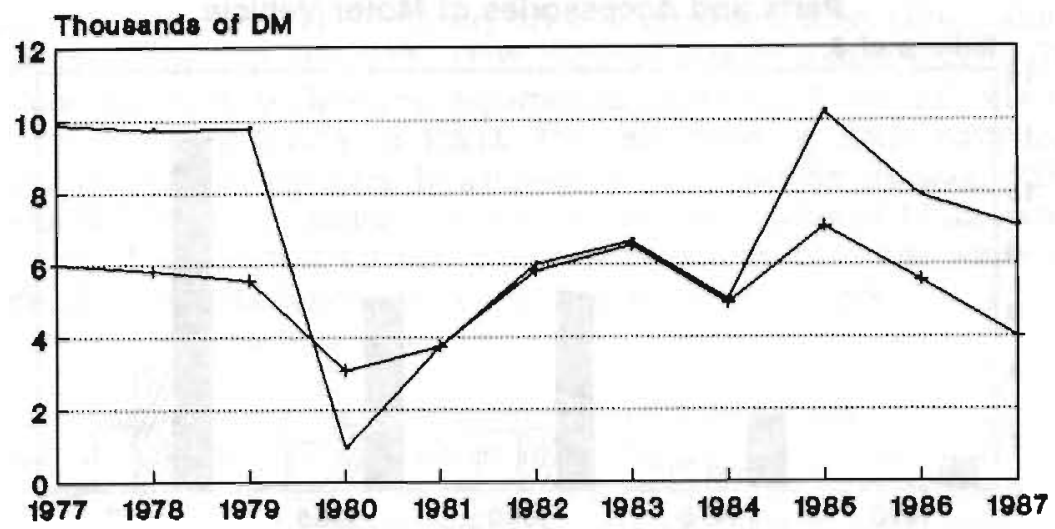

\section{- Motor Vehicle Manuf. + Parts Manuf.}

\section{Source: Statistisches Bundesamt}

by Peguform. Both firms deliver in order of assembly and receive final orders from Volkswagen through EDI five hours before assembly. Kautex is producing on the basis of information on the car production schedule that is provided two weeks in advance; Peguform has components in store and waits with final assembly until the final order has been received. The newest materials control system at Audi, which will be introduced at Volkswagen as well, provides production schedules no longer on a weekly, but on a daily basis. The schedule is revised daily (with a time horizont of six days) on the basis of inputs from all participants in the logistics chain. The system was introduced early in 1988 and already paid back its costs during the first year. By early 1989150 suppliers were keyed into the system, supplying 9,000 parts, i.e. $73 \%$ of the value of the external parts for the two Audi plants in Ingolstadt and Neckarsulm. Of these, $15 \%$ was connected on-line through the VDA interface 4915. Two transportation firms (Amberger and Scherm) are also included in the system, who take care of transitional storage and are receiving delivery orders several times a day for combined delivery of parts directly to the assembly line from various suppliers.

To reduce supply shortage risks just-in-time systems usually assume a single stage supply to eliminate transfer failures. In Germany this translates to a maximum distance of $200-300 \mathrm{~km}$. The strong pressure to reduce costs and to show flexibility in the delivery of components with an increasing number of variants, however, usually prevent a simple, larger-inventories solution. The possibilities of keeping (over)capacity available for unexpected changes in orders are also limited and costly. Solutions have to be sought in quick tool changing, high levels of preventive 
Figure 7.12

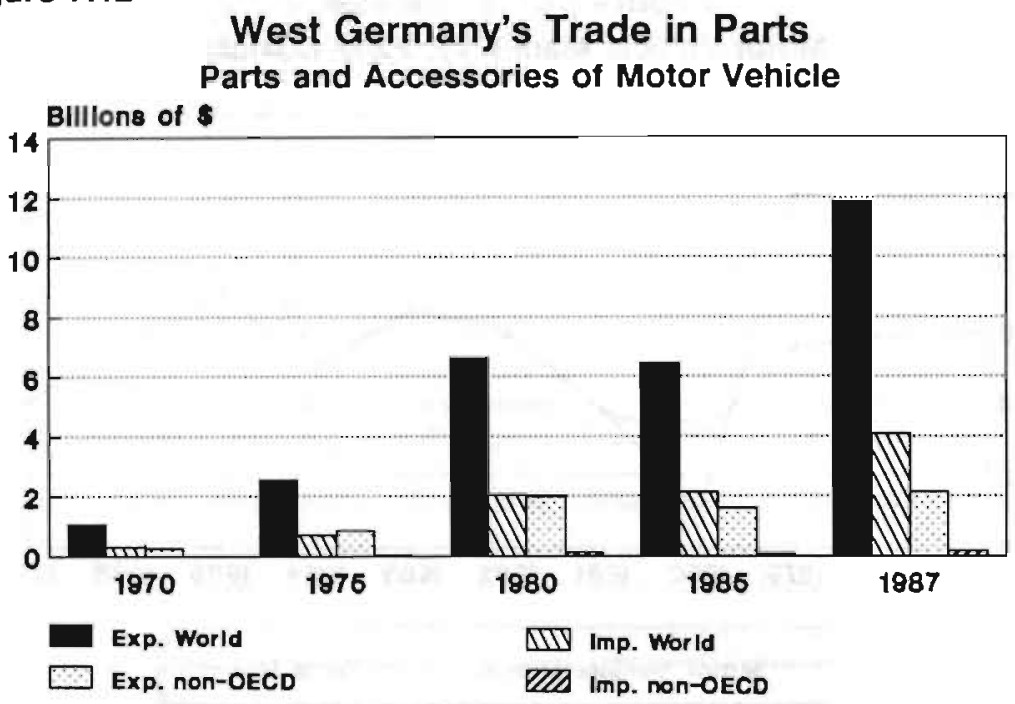

Source: OECD

Trade by Commodities, SITC $732.8 / 784$

maintenance to prevent 'in production' equipment breakdown, and investment in flexible production equipment, machining cells, robots, etc.. This is all the more necessary if one considers that high quality standards are the necessary correlate of just-in-time delivery. A supplier must be capable of developing a "U-Pass" quality control level, which results in a zero defect at the car assembly plant. The capacity must therefore also be in place to replace unexpected rejects quickly. Of special interest is, finally, the problem of packaging and transportation, where suppliers have to make considerable investments - usually aided by the car manufacturer or by independent transportation firms. Increasingly, special lorries are being designed to fit the transportation and delivery requirements of specific products, but also in answer to complaints about noise and air-pollution coming from the persons living along the supply lines of the car manufacturer.

new technologies, new entrants

Fourthly, rapid changes in technology have necessitated many auto makers to look outside their premises for know how concerning the possible uses of new materials and electronics. Know-how available at the components supplier has always been an important reason for outsourcing. In a period where several new technologies are becoming available for application in motor vehicles (new materials, ceramics, electronics, CAD, robotics, sensors) and the car is in many respects no longer a mature product, but one in its second youth, car manufacturers find themselves compelled to rely on supplier knowledge. Of course, several manufacturers (GM, Ford, Daimler-Benz) have also acquired a lot of knowledge by the take-over of 
high-tech firms, but even so their capacity to experiment and develop new components is limited. Examples of components for which the auto makers have shifted the responsibility to supplier industry firms are ABS-systems (Bosch, Teves), 4WDR systems (Steyer, Borg-Warner, Uni-Cardan), electronic fuel injection (Bosch, Lucas, TI, Motorola), active suspension systems (Boge, Monroe, Lotus), smart power steering (ZF, TRW, Bendix), climate control systems (Behr, Nippondenso). In West Germany, important suppliers like Bosch, ZF, VDO and FAG are investing heavily in $R \& D$. The high costs of $R \& D$ have led to cooperation between suppliers. In automotive electronics for instance, VDO is cooperating with Boge (active suspension) and Kolbenschmidt (ABS-systems), GKN and ZF established Viscodrive to develop and produce four wheel drive systems, Monroe and Bosch are cooperating in the development of advanced electronic car suspension systems.

The technological changes and the growing share of electronics in the value of an average car have aroused the interest of the big electronics firms and brought some new powerful players on the scene. 'Automotive Technologies' has recently been made into a separate entity within Siemens. For 1990/91 R\&D expenditures of DM $650 \mathrm{mn}$ have been planned, mainly in the area of automotive electronics. In its efforts to challenge the position of Bosch, Siemens finds support from the car manufacturers. Together with Daimler Benz the firm has developed an automatic four-wheel-drive system (4-Matic). For BMW it is developing an integrated engine-control system. Apart from Germany, Siemens also has development centers in the US and in Korea. In october 1988 it took over Bendix from Allied Signal, which provided knowledge in the field of actuators and sensorics. As Siemens is planning to develop and sell complete systems, it needs the sensors to generate the data for the electronic systems. Siemens' automotive boss Walter Kunerth expects that in the future the car manufacturers will continue to "possess the know-how about various functions and concrete ideas about the basic concepts for the electronic system. The supplier will then further develop and implement this concept" (AP November 1989, p.22). By the takeover of Kraftfahrzeug-Elektronik Nürnberg GmbH (KEN) from Triumph-Adler, Siemens has gained entrance to Volkswagen, that is buying electronic controls for ignition, fuel injection and engine controls from KEN.

A former competitor of Siemens, AEG-Telefunken, was taken over by DaimlerBenz. Since July 1989 the automotive activities of AEG are organized in 'AEG Autoelektronik'. It has a turnover of DM $750 \mathrm{mn}$ (about DM $500 \mathrm{mn}$ electrical and electronic parts), of which only $20 \%$ are coming from Daimler Benz. AEG produces for instance the controls for the ABS system of Teves, electronic ignition modules for Volkswagen and Audi. Together with LUK it has bought a 50\% interest in 'Atlas Fahrzeugtechnik' for joint development in the field of engine technology.

\section{enterprise politics}

Finally, it should be remembered that vertical de-integration is often not an inevitable thing to do, but a decision with advantages and disadvantages. 
Therefore, de-integration can also be used in enterprise politics as a threat to exercise pressure on the internal production activities and especially the workers, to improve their performance, discipline, productivity and quality, to change working hours, etc.. Outsourcing decisions are easier taken than carried out in the face of strong resistance from threatened employees, works councils and unions. In the course of negotiations the decision is sometimes withdrawn in exchange for concessions from the workforce. At Volkswagen, regular procedures have now been established, which ensure that workers get a chance to voice their opinions on an outsourcing decision (and eventually to bargain for a reversal of the decision) (see also Jürgens/Reutter 1989).

\subsection{Implications for the supplier industry}

Lamming (1989) predicts that the competitive pressures in the automotive supplier market will reduce the number of major suppliers in Europe from the present 1500 to less than 1000 . The remaining major suppliers will be larger and will be more inclined to source components in low-cost countries. Although these suppliers will be engaged in substantial R\&D, Lamming doesn't expect the European assemblers to entrust supplier firms with the complete development of major components, at least not in the foreseeable future. This would require a measure of trust that can only develop slowly in the face of a legacy of highly adversarial relations. Of course, to the extent that suppliers develop the potential to present the assemblers with products and technologies that they cannot produce themselves (at least not without a severe cost penalty), supplier-assembler relations will become more balanced. This would require not only the scale and technological capability of firms like Bosch, but also a conscious effort to develop a more active, strategic approach on the part of the suppliers.

What does all this mean for the different players in the West German automotive supplier industry? Clearly, the industry has been investing heavily in its future. Between 1978 and 1986, the West German motor vehicle industry invested DM $74.6 \mathrm{bn}$, of which DM 11.4 bn were invested by the supplier firms. Yearly investment expenditure per employee in the supplier industry more than doubled over this period, from DM 4,900 in 1978 to DM 11,000 in 1986 (Doleschal, 1989, p.34). Of course, not every firm can afford such expenditure and in fact many of them had to borrow heavily from the banks. An investigation by the Dresdner Bank, covering about 250 German supplier firms, showed that the financial position of these firms had deteriorated considerably in the recent past, in spite of record sales. Equity as a percentage of total non-financial assets sank from an average of $80 \%$ in 1985 to $65 \%$ in 1987 . Over the same period, the number of years needed to cover existing debt out of the cash flow increased from an average of less than six to 7.2. The Bank came to pessimistic conclusions concerning the future of the German supplier industry. The strength of the industry had always been in technology and marketing, but in the world of global markets and global sourcing by the assemblers, size was becoming more important. Foreign investment and/or acquisition would be necessary, but this would be very difficult for lack of financing. Lack of capital and lack of financial management would be a bottleneck 
here - and dependence on the banks and the capital market would therefore increase. The Dresdner bank emphasized that the supplier firms would have to invest not only in (foreign) markets, but also in R\&D. It argued that the level of currently $3-4 \%$ of turnover would have to increase to between 5 and $10 \%$ (AP April 1989, p.36).

Sleigh (1989) comes to similar conclusions, where he says that "much, clearly, will be determined by capital availability and the price of that capital will determine the future for many West European component manufacturers" (p.18).

There are, of course, some ways in which the car assemblers can support the suppliers in their efforts to deal with the demands made upon them. In exchange for (investements in) quality and punctuality the supplier may receive longer term contracts than the traditional one-year contract. Also, closer co-operation between assembler and supplier, joint development and the development of just-in-time arrangements are all factors pushing in the direction of single-source practices, replacing the old wisdom of at least two separate suppliers (supplying two thirds of the required parts with the rest of the parts produced in-house). Ford, for instance, has recently used a new supplier approach in its Fiesta project. From the first concept to serial production the same supplier was engaged for the various parts. That meant that decisions abouit suppliers had to be taken well in advance of serial production, sometimes four years in advance. As a consequence, the number of late changes was reduced by $40 \%$. It also involved a move towards single sourcing: $40 \%$ of the Fiesta parts come from one supplier, 47 from two and only $13 \%$ from more than two (AP September 1989, p.50). Table 7.7 shows how far single sourcing has advanced for the West German assemblers.

Table 7.7

\begin{tabular}{lccccccc}
\hline Buyer & $\begin{array}{c}\text { Produced } \\
\text { units }\end{array}$ & \multicolumn{2}{l}{ Volume Bought } & $\begin{array}{c}\text { Total } \\
\text { Suppliers }\end{array}$ & $\begin{array}{c}\text { of which } \\
\text { single } \\
\text { source }\end{array}$ & $\begin{array}{c}\text { of which } \\
\text { JIT } \\
\text { source }\end{array}$ & $\begin{array}{c}\text { vertical } \\
\text { integration }\end{array}$ \\
\hline & x 1000 & $\begin{array}{c}\text { Total } \\
\text { DMbn }\end{array}$ & $\begin{array}{c}\text { Import } \\
\%\end{array}$ & & & & \\
Audi & 422 & 7 & 12 & 1100 & 900 & 10 & 65 \\
BMW & 489 & 9,5 & 20 & 1000 & 800 & 10 & 45 \\
Ford & $958^{4}$ & 13 & 46 & 1300 & 800 & 140 & 37 \\
Mercedes & 536 & 22 & 13 & 2500 & 600 & 70 & 62 \\
Opel & 989 & 8,6 & 45 & 1150 & 1000 & 23 & 40 \\
Porsche & 29 & 1,5 & 5 & 600 & 580 & 40 & 29 \\
Vw & 1463 & 20 & 12 & 2600 & 900 & 90 & 47 \\
\hline
\end{tabular}

'Sole source of a part or system for one type of car; ${ }^{2}$ Order frequency at least once every 24 hours; ${ }^{3}$ Estimates; various definitions; ${ }^{4}$ Including German car types produced in Belgium. 
Table 7.8

Structure of the Automotive Supplier Industry

\begin{tabular}{|c|c|c|}
\hline $\begin{array}{l}\text { Automotive Sales } \\
\text { as a \% of Total Sales }\end{array}$ & $\begin{array}{l}\text { Usually } \\
\text { less than } 30 \% \text {. }\end{array}$ & $\begin{array}{l}\text { (much) more } \\
\text { than } 50 \%\end{array}$ \\
\hline \multicolumn{3}{|l|}{ Number of Employees } \\
\hline$>10000$ & $\begin{array}{l}\text { independent } \\
\text { own technology base } \\
\text { example: Siemens }\end{array}$ & $\begin{array}{l}\text { equal partnership } \\
\text { own technology base } \\
\text { example: Bosch }\end{array}$ \\
\hline $\begin{array}{l}>1000 \\
<10000\end{array}$ & $\begin{array}{l}\text { low dependency } \\
\text { highly competitive } \\
\text { environment } \\
\text { exit option } \\
\text { example: Schaeffler }\end{array}$ & $\begin{array}{l}\text { highly dependent } \\
\text { competitive } \\
\text { environment } \\
\text { usually first-tier } \\
\text { suppliers } \\
\text { example: Pierburg }\end{array}$ \\
\hline$<1000$ & $\begin{array}{l}\text { Specialised in a } \\
\text { smal range of } \\
\text { products } \\
\text { highly competitive } \\
\text { environment } \\
\text { example: Solo }\end{array}$ & $\begin{array}{l}\text { completely dependent } \\
\text { strong pressure to } \\
\text { reduce costs } \\
\text { danger of becoming } \\
\text { second-tier supplier } \\
\text { example: Nosag }\end{array}$ \\
\hline
\end{tabular}

As noted above, the supplier firms vary strongly in size, technological prowess and competitive environment. Table 7.8, derived from Doleschal (1989), distinguishes 6 categories of suppliers on the basis of two criteria: the importance of automotive sales in total sales and the size of the firm as measured by the number of employees. Let us look at the impact of the recent trend of de-integration on these different categories. Large firms, for whom the automotive market is not the major outlet for their products (for instance Siemens), can be expected to become more active, either by taking over smaller, more specialized suppliers, who are in need of technological support, or by expansion of already existing activities to pick up a share of the growing market. Technological know-how will be an important determinant of their activities. The same can be said for those large firms, that are largely dependent on the car market. An enterprise like Bosch has so much to offer in terms of technology, that its relations with the car manufacturers can only be described in terms of mutual dependence and partnership. Firms in this category usually have a strong and profitable market position, based on product patents and related production know-how. If we now look at the somewhat smaller firms with between 1000 and 10000 employees, the implications of dependence or 
independence of the car market become more pronounced. Since exclusive product technology plays less of a role here, competition is strong as a consequence of the highly competitive conditions of the world auto market. Car manufacturers are exerting heavy pressure on their suppliers to reduce prices and costs, while at the same time requiring higher quality and delivery at the shortest possible notice. Suppliers that do not depend on the car market have a real exit option and do indeed choose that option if they find the auto makers' demands unbearable. The suppliers, who depend on the car market, have no choice but to invest in production technology, telecommunications and (sometimes) product innovation. They have to do this in order to stay first-tier suppliers of complex components. Of course, among the firms falling into this size category, there are extreme differences as to the possibilities they have to maintain their position. More than in the past, their competitiveness will depend on the mastery of some field of technology and/or on design and systems management capabilities. The smaller firms, finally, with less than 1000 employees, are under constant pressure to reduce costs. Those with a low dependence on the car market tend to be or become second-tier suppliers. Those who are dependent on the car market often lack the means to invest in their status as first-tier supplier. For these firms, quite often it isn't really sensible to do so. Instead, they can rely on and try to improve on their competence in a specific technique, a process or a material, and to become a reliable second- or third-tier supplier to a first-tier components supplier. To the extent that they possess strategic knowledge or require large investment funds, they form the object of take-over schemes by the larger firms. Actually, quite a few firms in this category already turn out to be partly or wholly owned by larger supplier firms. "The survival strategy of the sub-supplier is specialization, automation, flexibility. He has to be leading in terms of costs. Everything is a question of price - with growing pressure from imports" (AP April 1990:2, p.28). Doleschal concludes that medium-sized supplier firms will probably be the most important and dynamic actors in the industry, but more than in the past, these firms will be part of larger enterprises, that possess the financial and technological means necessary to underpin their competitive position.

Summarizing, the de-integration trend in the West-German automobile industry has the following major consequences for the automotive supplier industry:

- $\quad$ Suppliers will increasingly invest both in R\&D (especially the larger ones) and in new plant and advanced production equipment. Capital costs per employee will rise - and personnel costs may rise as well, also because the influence of the IG Metall will follow the integration achieved though data links.

- Suppliers will be highly mobile, by a further expansion of foreign operations as well as by the setting up of just-in-time plants in the vicinity of car assembly plants.

- Suppliers will try to separate the functions of processing, assembly, and storage, centralizing processing and decentralizing the other two for purposes of just-in-time delivery.

Because of exit and take-overs, vertical de-integration in the car industry will probably lead to concentration - and probably to increasing vertical integration - in the automotive supplier industry. 



\title{
8. International Competition and National Institutions. The Case of the Automobile Industry
}

\author{
8.1 The Japanese 'threat' \\ 8.2 Explanations \\ 8.3 The Toyota production system \\ 8.4 Toyotism \\ 8.5 The social context \\ 8.6 Leaming from Japan \\ 8.7 Changing social institutions \\ 8.8 The German/Scandinavian model \\ 8.9 Conclusion
}

The competitive performance of the Japanese automobile industry over the past two decades has been astonishing. Hundreds of books and articles have been written trying to describe and explain this phenomenon. The car manufacturers of Western Europe and the United States are still recovering from the many blows dealt out to them and anxious to learn whatever can be learnt from Japan. The following article deals with the problem of learning from the experiences of others, from other countries with other traditions and institutions. The basic argument is that to learn is not to imitate. Car manufacturers that simply try to copy Japanese practices are unlikely to regain competitiveness in the world market.

\subsection{The Japanese 'threat'}

In 1988, the world production of motor vehicles (passenger cars, trucks and buses) amounted to 48.6 million units. Of these, 14.9 million were produced in Western Europe. Although there is much talk about a maturing of the car markets, the fact is that the total number of cars on the roads in still growing everywhere. We are all familiar with the consequences: congested cities, air pollution and traffic

\footnotetext{
${ }^{1}$ Published in C. Freeman \& L. Soete (ed.), New Explorations in the Economics of Technological Change, Pinter Publishers. London/New York, 1990, pp. 157-174. Research on which this article is based was carried out in the framework of the following projects: 'Risks and Chances for Workers of the Present Restructuring in the World Automobile Industry' (Science Center Berlin); 'Comparing Capitalist Economies, Variations in the Governance of Sectors'; 'Renewal and Restructuring at Volvo Car BV' (Programme on Technology, Work and Organisation). See also Dankbaar 1988a, 1988b, 1989a, 1989b, Dankbaar \& Van Diepen 1990.
} 
accidents with a terrible death toll year after year. This article, however, deals with another more mundane problem, that comes to the minds of European car manufacturers upon hearing figures like these. That problem is: why is it that the West European car industry is producing only 14.9 million units per year? The European share of world motor vehicle production used to be much higher. Of course, we know what happened: over the past two decades the Japanese motor vehicle industry gained an enormous share of the world market. The traditional homelands of the auto industry were conquered one by one with the result that approximately every fourth car sold in North America and every eighth car sold in Western Europe is Japanese. The Japanese share of world production was less than $2 \%$ only in 1958 (188,000 vehicles). Ten years later it had risen to $14 \%$, in 1978 it was $22 \%$ and in 1988 the Japanese manufacturers produced $12,699,803$ motor vehicles, or about $26 \%$ of world production. About half of these, 6.1 million, were exported (1.4 million to Europe). The stunning competitive performance of this industry alone (but of course, there were more) was sufficient to change the balance in international economic relations, not just between Japan and the United States, but worldwide. It is at the basis of a revival of protectionist sentiment. It also resulted in some of the largest investment programs that private industry has ever seen, as the old giants of the industry tried to regain strength.

\subsection{Explanations}

What are the explanations for the success of the Japanese car manufacturers? In the course of time, many different explanations have been provided. An early one, probably most current and most valid in the 1960s, referred to the lower wage level in Japanese industry, compared to the earnings of the automobile workers in Western Europe and North America. Even after wage levels started to rise for the employees of Toyota, Nissan and the other Japanese manufacturers, the argument kept some of its validity, due to the low level of vertical integration in the Japanese car industry. The Japanese manufacturers are really assemblers. Parts and components are supplied by a network of independent or semi-independent firms, where wages are usually much lower. Whereas the high level of integration of firms like Ford and General Motors, who even produced some of their own steel and glass, had long been considered a competitive advantage, Japanese practice showed that it could also be a disadvantage, because high 'automotive' wages have to be paid during all stages of the production process. Still, by now the differences in wage levels between Japan and its competitors have become much less important and cannot explain the continuing competitive successes of the auto industry.

Another popular explanation was that the Japanese had simply been extremely lucky. This may be called the explanation of the 1970s. The Japanese were indeed lucky in that they had exactly the right products to offer, when the oil crisis hit the West and demand for small, fuel efficient cars soared. Especially in the United States, where cars had become bigger and bigger and fuel prices had always been low, the traditional car manufacturers were caught off-balance. Even if there had not existed a 'big-car culture' in these enterprises, the lead times and 
organisational rigidities of these huge firms are such, that changing their basic orientations takes many years if not decades. The two oil crises of 1973 and 1979 provoked a decade of crisis and uncertainty in the North American car industry. To call the Japanese success pure luck, however, would be too easy. That wouldn't explain why other producers of small cars, who already had access to the North American market (Volkswagen), couldn't expand their market share and indeed lost most of it in the course of the 1970s. It was really a combination of circumstances (there was no room for big cars in Japan), foresight (a strong interest in fuel efficiency and pollution control) and luck, plus the willingness and ability to use this golden opportunity. In the end, ability was more important than luck. By 1980 , it was clear that the Japanese success was based not just on low wages, let alone on luck, but on the ability to produce high quality products at low costs. Several American studies of the Japanese cost advantage, including one ordered by the United Auto Workers, all came to the same conclusion (Flynn, 1982).

High productivity then can be called the explanation of the eighties. High productivity itself, of course, must also be explained. A variety of reasons has been adduced, some already old, others new. One reason was culture. Parts of Shintoism, the recent experiences of war and reconstruction, Japanese group mentality, their willingness to identify with 'their' firm, these and other aspects of Japanese culture were seen to produce a specific Japanese work ethic, comparable to the Protestant Ethic that according to Max Weber had explained the rise of capitalism in Europe.

Another reason mentioned was simpler and more straightforward: exploitation. And indeed, the speed and intensity of work in Japanese assembly plants was certainly higher than in most Western plants. It had been described in vivid detail by Satoshi Kamata (1986) in his book 'Japan on the passing lane', based on his own experiences as an assembly line worker. The assembly line with high speed, short-cycled production tasks is still the cornerstone of Japanese industry. Still, it is difficult to explain the competitive advantages of the Japanese only by the fact that the assembly line workers work harder.

A third reason for Japanese performance was found in the levels of mechanization they had achieved and especially in the use of robotics. Japanese statistics seemed to show that they were way ahead in the use of robots. On closer inspection, the level of mechanization was less spectacular. Investigating teams from western countries came to the conclusion that there was nothing in the way of robotics that they didn't and couldn't do themselves. The interesting thing was that the Japanese used robotics and other means of mechanisation where they didn't seem to be profitable from a western perspective.

This finally then leads to a fourth major explanation: the Japanese seemed to have a better system of production management. Without denying the importance of the other factors mentioned, the great achievement of the Japanese car manufacturers is no doubt that they have developed new improved methods for the organisation of production in an industry where everything had been improved already over and over again. It is to this point that we will now turn. 


\subsection{The Toyota production system}

Ever since the days of Henry Ford, automobile production has been organised on a moving assembly line according to the principles developed by Frederic Taylor and by Ford himself. In accordance with Taylor's ideas of 'scientific management', direct production work is short cycled (usually less than one minute) and carefully measured. There is a strong division of labour between work preparation, work execution and quality control. Ford's specific contribution consisted of the introduction of the continuously moving assembly line and other forms of mechanization, which determined the pace of work. The influence of this production concept has been at work in all manufacturing industries and in all industrialized countries. 'Fordism' as it has been called, was of course also introduced in the Japanese car industry after the Second World War. Schonberger (1982) has even argued with regard to the modern Japanese manufacturing methods, that "the Japanese out-Taylor us all" (p.193). In some respects, for instance where it sticks to the central role of the assembly line, this is certainly true. In other respects, however, the Toyota Production System represents a strong departure from the principles that guided Henry Ford.

The Toyota Production System (TPS), which has in its turn become a model for other Japanese car manufacturers and indeed for the world car industry, is connected with the name of Ono Taiichi. With great endurance, if not fanaticism, Ono Taiichi spent several decades at various posts to improve the production system at Toyota (Cusumano, 1985). Guiding principle of his production system is the elimination of waste. Waste, that is represented for instance by in-process inventories (buffers), repair work, and workers standing idle. All these are quite common in a traditional Fordist production system, but Ono Taiichi set out to eliminate them. He made direct production responsible for quality, going as far as allowing production workers to stop the line, if they cannot achieve the required quality. He eliminated buffers and reduced inventories of parts and components to a bare minimum. Bottlenecks and quality defects thus became visible immediately. Workers were supposed to support each other as soon as they had finished their own particular task (teamwork) and the time allowed for the tasks was reduced accordingly (no more idle workers standing around). Gradually then, the TPS was organized around the two related principles of 'Just-In-Time' and 'Total-Quality-Control'. If everything is produced just in time for the next stage of production and all buffers and inventories disappear, quality has to be perfect (zero defects). Otherwise, the flow of production gets disrupted. But there is more to Total-Quality-Control than the necessity (and ability) to do everything right the first time. TQC also stands for the idea of continuous improvement of the production system. Workers were not only asked to do everything quickly and correctly, but also to think of ways of doing it quicker and better. Quality Circles were organized where workers could develop new ideas and work them out together with engineers if necessary. This represents another major departure from the principles of Taylor and Ford. Taylor proceeded from the assumption that there is one best way of doing things and on that basis developed 'a fair day's work' as a norm for the production worker. Ono Taiichi's approach is based on the idea, that there is always a better way of doing things. The factory can and must 
be continuously improved. The TPS therefore represents a system of permanent improvement and permanent intensification of work.

\subsection{Toyotism}

All this resulted in a production system, that differs in crucial ways from the traditional Fordist system. Table 8.1 shows some of the differences by comparing two typical assembly plants in Japan and the United States. Productivity in the Japanese plant (hours per car) is more than twice as high as in the American plant. The total workforce of the U.S. plant is also more than twice as high as the Japanese workforce. If working hours would be the same, therefore, both plants would produce the same number of cars!

Looking at the structure of the workforce, we find some more characteristic differences. The number of persons working directly in production in the American plant is double that of the Japanese plant. For all other (indirect) functions, however, this relationship is even higher. For Quality Control the ratio is 2.3, for Manufacturing Engineering 3.1, for Production Control 3.3 and the Management Staff in the American plant is even 4 times as large as in Japan. Thus, even though the Toyota Production System started out from the Fordist system, it has now gained a quite distinctive identity and it is only logical that the concept of 'Toyotism' has been coined to designate it as an alternative to Fordism (Dohse et a..).

Krafcik (1988a, 1988b) has characterized Toyotism as a 'fragile' production concept as opposed to the 'robust' character of the Fordist system. It is fragile, because it lacks the inventories, buffers, quality control and repair areas, that were introduced in the Fordist system to ensure an uninterrupted flow of production. They were considered regrettable, but necessary costs, in view of the limited motivation and lack of knowledge of the assembly workers and the levels of quality achievable by component suppliers. Ono Taiichi saw them as 'waste' and set out to eliminate them. Of course, this could only be done by eliminating their causes. The functioning and the cohesiveness of this fragile system depends on new, cooperative assembler-supplier relations, on an intricate individualized method of rating and paying employees, on specific labour relations with a management-dominated union-organisation. Toyotism is, in other words, not just a new management technique, but involves - as indeed Fordism did - also a great deal of social and institutional innovation.

\subsection{The social context}

Naturally, the Toyota Production System is rooted in Japanese society. Whatever new methods and organisational forms Ono Taiichi thought up, they had to be fitted to and accepted by Japanese social institutions. The development of Toyotism is closely related to the development of economic, social and cultural institutions in post-war Japan. If we look at the present situation, there are some 
Table 8.1

Assembly Plant Comparison: Japan- United States, ca. 1980 (employees)

\begin{tabular}{|c|c|c|c|}
\hline & & & Ratio \\
\hline Funclion & Japan & United States & $\mathrm{Japan}=1.0$ \\
\hline $\begin{array}{l}\text { Ouality Control } \\
\text { (inspection) } \\
\text { (emissions) } \\
\text { (engineering) }\end{array}$ & $\begin{array}{c}156 \\
(120) \\
(26) \\
(10)\end{array}$ & $\begin{array}{r}359 \\
(302) \\
(37) \\
(20)\end{array}$ & $\begin{array}{l}2.3 \\
(2.5) \\
(1.4) \\
(2.0)\end{array}$ \\
\hline $\begin{array}{l}\text { Production Control } \\
\text { (scheduling) } \\
\text { (materials) }\end{array}$ & $\begin{array}{l}95 \\
(11) \\
(56)\end{array}$ & $\begin{array}{c}310 \\
(66) \\
(216)\end{array}$ & $\begin{array}{c}3.3 \\
(6.0) \\
(3.9)\end{array}$ \\
\hline Product Enginecring & 22 & 6 & 0.3 \\
\hline $\begin{array}{l}\text { Manufacturing } \\
\text { Engineering } \\
\text { (maintenance) } \\
\text { (janitors) }\end{array}$ & $\begin{array}{l}132 \\
(62) \\
(10)\end{array}$ & $\begin{array}{l}411 \\
(207) \\
(114)\end{array}$ & $\begin{array}{r}3.1 \\
(3.3) \\
(11.4)\end{array}$ \\
\hline $\begin{array}{l}\text { Production } \\
\text { (painting) } \\
\text { (assembly) }\end{array}$ & $\begin{array}{l}1324 \\
(250) \\
(641)\end{array}$ & $\begin{array}{l}2640 \\
(421) \\
(1603)\end{array}$ & $\begin{array}{l}2.0 \\
(1.7) \\
(2.5)\end{array}$ \\
\hline Management Staff & 33 & 132 & 4.0 \\
\hline Grand Total & 1762 & 3885 & 2.2 \\
\hline Hours Per Small Car & 14 & 31 & 2.2 \\
\hline
\end{tabular}

Source: Cusumano (1985), p.329

elements in the social context of the automobile industry, that are obviously helpful to the success of Toyotism. The industrial relations system in Japan is characterized by strong unions at the company level and very weak union organizations at the industry level. Industrial unionism as exemplified by the United Auto Workers in the United States or the IG Metall in West Germany was defeated in Japan in the early 1950s. With the support of managements companyoriented unions were set up, that were willing to proceed on the assumption that the (long term) interests of the company are identical with those of the workers (cf. Halberstam (1986) for a description of the struggle for control of unionism at Nissan). Another important element in the context of the industry is the educational system. The Japanese system doesn't know a vocational training system outside of private industry. After (a generally high level of) general education, 
workers learn specific trades and professions inside the firm where they come to work. As this training is firm-specific, mobility between firms is difficult, which in turn allows firms to invest into their workers. As a result, the Japanese labour market is highly segmented. There is a large gap (in status and in pay) between those who managed to become members of the body of permanent employees of one of the big firms and those who find themselves on the other side of the track with less security and lower pay. The economic and social policies of the Japanese government in support of the educational system, of the organisation of the labour market and last but not least of the automobile industry itself are of course also important elements of the social context of Toyotism. No study of modern Japan is complete without reference to the Ministry of International Trade and Industry. The influence of MITI has often been overestimated and its plans for the auto industry were often disregarded by the manufacturers. Nevertheless, government industrial policies, protectionism as well as structural policies, the MITI approach toward technological planning and problem solving, are all part of the environment that influenced Toyotism.

At the factory level, this environment shows up in various elements of Toyotism that are not immediately visible on the shop floor, but nevertheless are crucial to its success. The permanent employees, for instance, pay a price for their job security and social status where they are expected to identify completely with their firm, to forego vacations and to be willing to work overtime whenever necessary, to accept new assignments and new locations of work without protest and to devote their free time to think about further improvements of the organisation of their work. They are also expected to accept the intricate system of supervision, rating and rewards, which has led some observers to the statement that the personnel department at the Japanese car plant fulfils the same functions that the industrial engineering department fulfils at the traditional Fordist plant, i.e. ensuring that workers work to the limits of their capabilities. Interestingly, although there may be fewer management staff at the Japanese plant (as shown in Table 8.1), it was shown in comparison with German plants that there are far more persons with a supervisory function, who play an important role in the system of individual rating of performance (Jürgens and Strömel, 1987). The social distance between the workers and these supervisors, who have also direct production tasks, seems to be less than in Western countries. This contributes to the potential for team work. It may be explained by the fact that all workers have entered the firm at the same level and were promoted (or not) through individual ratings and training. Similarly, the social distance between production workers and engineers has remained small due to the fact that the engineers for lack of staff and colleagues were forced to make active use of the process knowledge of the workers.

\subsection{Learning from Japan}

Obviously, the Japanese social context is not available elsewhere. What does this imply for the efforts of Western car manufacturers to learn from Japanese experiences and to introduce the Toyota Production System in their factories? 
Should they try to install not only a new production system, but a new social context as well in their countries? Is that at all possible? Should they for instance try to break industrial unionism or demand the abolition of the independent vocational training systems in their countries? At this point we can roughly distinguish two positions. On the one hand it is argued that the Toyota Production System is essentially a set of management techniques that can be introduced anywhere in the world. On the other hand it is said that the success of the Toyota Production System is rooted in Japanese social institutions. A transfer of the system to another social context will therefore be unlikely to succeed.

John Krafcik (1988a, 1988b) has argued forcefully, that the social context doesn't matter very much. He has made a comparative analysis of the performance of auto assembly plants in Europe, Japan and North America and sees his evidence as refuting the "country explanation for high performance":

"Intra-regional variation in operating performance was found to be significant in North America, Europe, and Japan. Substantial overlap among these regions and relatively consistent international intracorporation performance supports the notion that corporate parentage is at least as important as location in determining the performance of an assembly plant."

(Krafcik, 1988a, p.115)

Figure 8.1 shows that of the 38 assembly plants investigated by Krafcik, the best performing plant (in terms of productivity) was Japanese-owned and located in Japan. ${ }^{2}$ It also shows that European-owned assembly plants in Europe were on average showing the worst performance. However, the best performing plant in Europe had higher productivity than the worst performing in Japan. Apparently, the 'world class' performance levels of the Japanese plants can also be achieved in other countries. In an effort to explain the variations in performance, Krafcik has developed a composite indicator for the use of Japanese management methods. Included are such indicators as the percentage of floor space available for repair, the presence of teams, the level of unscheduled absenteeism, and the possibility for visual control of the production process. He finds that good performance correlates with the use of 'Japanese' concepts of production organisation. Figure 8.2 shows that 'fragile' management, as measured by Krafcik's indicators, is correlated with high productivity, whereas 'robust' (Fordist) management is generally associated with low productivity. All Japanese-owned plants are in the fragile-high productivity corner. Almost all the plants of one unidentified US multinational, however, are also in this corner. Krafcik cannot say this, but these plants can only be Ford plants. Ford has tried very hard to introduce Japanese methods into its plants. Besides that, it was running almost all of its plants at full capacity during the period under investigation, which in all likelihood led to high productivity scores. Interestingly, figure 8.2 also shows that one of these plants scored high on productivity while the management index indicated a highly 'robust' approach.

\footnotetext{
${ }^{2}$ In his analysis Krafcik has made corrections for differences in product, so that his findings express 'real' differences in productivity, as if all plants were producing more or less the same car.
} 
Figure 8.1

Range of World Productivity Performance

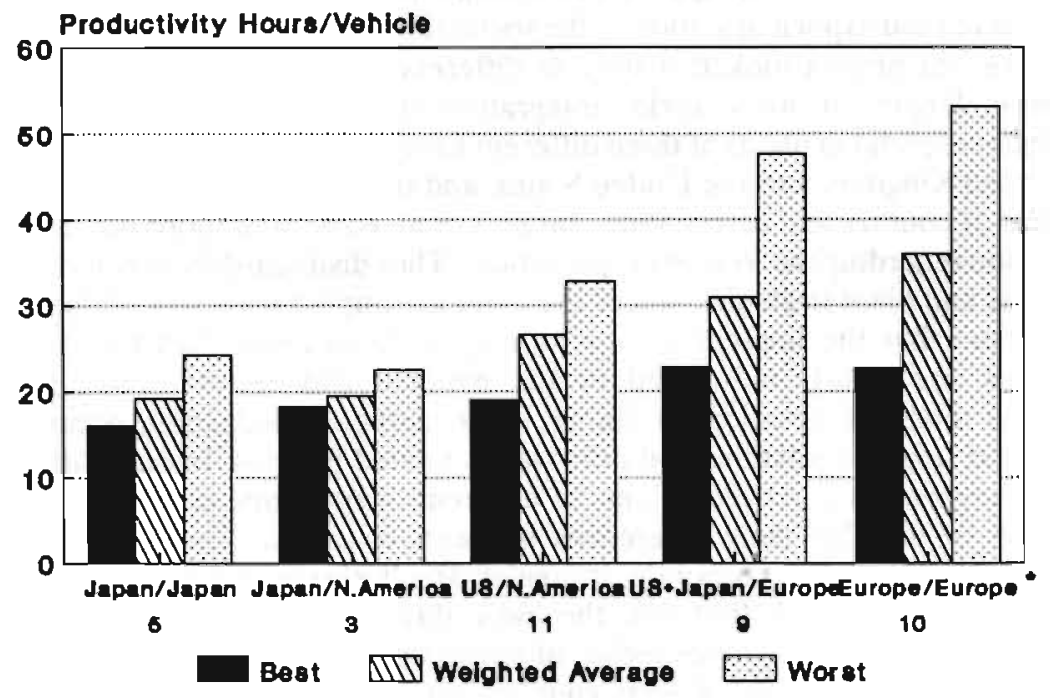

- Parent Looation/Piant Loodion/8ample 81zo

Krafcik and others, who base themselves on the same research (Jones/Womack, 1988), basically argue that 'world class' performance levels can be achieved by adopting the Japanese system of production management. They point to evidence from the United States, that it can indeed be transferred to other countries quite easily.

"The opening of the first Japanese plants - Honda in Ohio, Nissan in Tennessee, and the GM/Toyota joint venture in California quickly eliminated all "cultural" explanations of Japanese competitiveness. These plants showed that American workers and managers could produce cars with the same productivity and very nearly the same quality as equivalent plants in Japan." (Jones /Womack, 1988)

There is, of course, no reason why the same should not be possible in Europe. And indeed, Nissan has established a new plant in Great Britain, which seems to perform quite well. Ford's efforts, however, to introduce 'Japanese' methods into its British plants seem to be far from successful and meet with resistance from local managements as well as from the workers. Over the past decades, the British car industry has not performed well and the British-owned part of it has performed worst of all. Explanations of the demise of the British-owned car industry have often pointed to inflexible social institutions, that made it impossible for the 
industry to adapt to the new competitive challenges. Krafcik's findings and the Nissan experience on the other hand seem to point to a failure of management.

In another international comparison of automobile assembly plants, Jürgens et al. (1989) have paid explicit attention to the social ramifications of plant performance. This research project looked mainly at differences in work organization (team concepts, length of work cycle, integration of tasks, supervisory structure, automation levels) in plants of three different car manufacturers in West Germany, the United Kingdom and the United States, and tried to explain these differences in terms of country and corporation. Jürgens et al. come to a more differentiated conclusion regarding the "country explanation". They distinguish between corporate strategies and plant strategies, where the latter are implementations of the former. They argue that the implementation strategies, much more than the corporate strategies, are clearly influenced by the national and sectoral institutions of industrial relations, vocational training, labor market organization, occupational health and safety regulations and other labor related policies. In fact, differences in work organization between plants of different firms in one country were often found to be smaller than differences between countries. That doesn't mean, however, that different corporate strategies aren't clearly recognizable in plant practices. Jürgens et al. find that the basic thrust of a corporate strategy, for instance whether it emphasizes technical innovation or manpower rationalization, shows up in plant practice of every country, but

"the influence of location of the plant is modifying and overruling many aspects of the influence of corporate decision making. (...) The national systems of industrial relations and other labor-related policies and institutions in the three countries each have a particular selective effect on aims and priorities of restructuring activities in the plants. (...) These country-specific patterns of selection interact with the corporate strategic profiles, which leads to characteristic blends and mixtures."

(Jürgens et al., 1989, p.361/2/3; transl.:bd)

Note that these country-specific patterns of plant-level work organization do not necessarily exclude the possibility of large differences in productivity and product quality between plants in the same country, as they have been found by Krafcik. On the contrary, Jürgens et al. find similar differences in plant productivity, not only between countries, but also within the same country and/or within the same corporation. ${ }^{3}$ The insight that Jürgens et al. contribute to the debate, therefore, is not that 'Iocation explains performance', because it obviously does not, but the simple and nonetheless important point that 'location matters'. The social and institutional context will always be reflected in the actual practice of production organisation. Any effort to introduce new management techniques in a factory therefore will have to deal with this context. Where Krafcik points out that high

\footnotetext{
${ }^{3}$ Jürgens et al. have not corrected for product differences as Krafcik has done, but they have selected plants, that are producing comparable models (sometimes the same) for the same market segment. Their data show that, especially in the US, plant performance is showing strong cyclical movements through the years. Plant comparisons should therefore preferably be based on data over a time period of several years.
} 


\section{Figure 8.2}

\section{Management Style and Productivity: Japan, N. America, Europe}

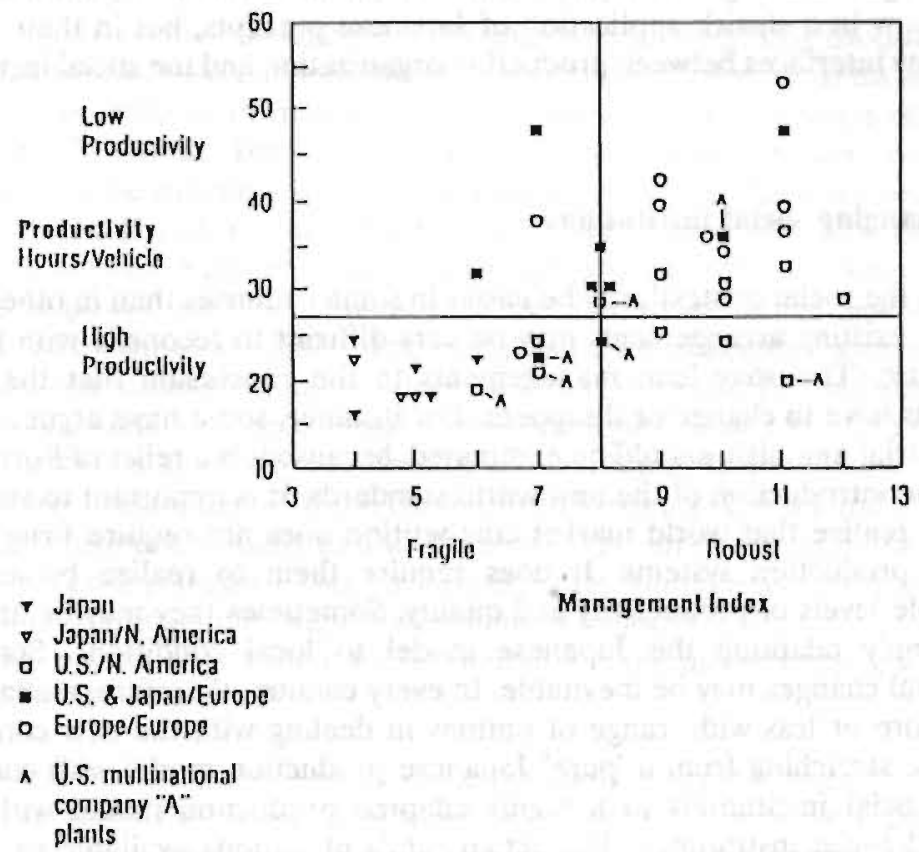

Source: Krafclk (1988b), p. 49

productivity can be associated with the use of some 'Japanese' methods, Jürgens et al. make clear that it is absolutely necessary to find out how these new techniques have been matched to the social context. Whereas a removal of repair areas on the shop floor may be an obvious sign of management's efforts to apply Japanese lessons, management's real achievement in this plant may very well be the way in which it has convinced workers and unions to go along with the new approach. It would then be highly misleading to explain high productivity in this plant by reference to the first measure, which is technically easy to achieve. If management fails to reconcile the new methods and the social context, we can expect either a return to 'robust' management methods or a combination of fragile management with low productivity.

Returning to the questions raised above, we can conclude on the basis of the contributions by Krafcik and by Jürgens et al. that the Toyota Production System, brought down to a set of rules for the management of production, can be 
introduced in other countries. However, just as the TPS is rooted in Japanese society and history, the application of these rules in another country will have to deal with the existing social context, the social institutions and traditions of that country. Just as Fordist factory regimes in France are quite distinct from Fordism in Germany, 'Toyotism' in different countries will also show different features. Able managers can organize high productivity plants everywhere, but their ability doesn't show in a slavish application of Japanese precepts, but in their handling of the many interfaces between production organization and the social institutional context.

\subsection{Changing social institutions}

'Handling the social context' may be easier in some countries than in others. Some important existing arrangements may be very difficult to reconcile with the rules of Toyotism. This may lead managements to the conclusion that the existing institutions have to change or disappear. For instance, some have argued recently that industrial unionism should be eliminated, because it is a relict of Fordism that hinders the introduction of the new world standards. It is important to stand back here, and realize that world market competition does not require firms to copy Japanese production systems. It does require them to realize by and large comparable levels of productivity and quality. Sometimes they may be able to do so by simply adapting the Japanese model to local conditions. Sometimes, institutional changes may be inevitable. In every country, therefore, managements have a more or less wide range of options in dealing with the new competitive challenges, stretching from a 'pure' Japanese production model with completely changed social institutions to a highly adapted production model with almost unchanged social institutions. The actual range of options available to managements in a specific country depends not just on the prevailing context, but also on the creative and political capacities of managements.

It is necessary to mention 'political' capacities here, because the process of changing social institutions is necessarily a political one. It involves bargaining with various social groups and organizations, the writing of new contracts, the construction of new institutions and sometimes legislation. Social institutions are usually a product of the interaction of various social actors and cannot be simply created by one group of actors. The interaction can be co-operative, but also confrontational, which again depends not just on circumstances, but also on strategic choices made by the actors themselves.

Take for example the case of changes in the institutions of industrial relations in the various car producing countries over the past decade. The institutions, rules and organisational forms dealing with industrial relations are typically national in character and vary more between countries than between firms (Dankbaar, 1989a; Jürgens et al., 1989). Over the past decade, managements in all car firms have introduced new technologies and new production concepts. Everywhere this involved dealing with the prevailing system of industrial relations. In Great Britain and the USA, the prevailing system tied workers' rights and rewards closely to the 
existing 'Fordist' system of work organization. In the USA for instance, job security depended on seniority, which was tied to a carefully defined system of job classifications. In Great Britain, job descriptions were closely tied to manning levels, with the additional complication that workers with different jobs were often represented by different unions.

In these countries, the introduction of Toyotism, e.g. integrating production tasks and quality control tasks and introducing team concepts, necessarily involved major changes in the balance of interests that had been produced in years of collective bargaining. In Great Britain, managements supported by the conservative government chose to follow a confrontational course. As a consequence, industrial relations in the British car industry have changed considerably, especially at the plant level, where the power of shop stewards has been reduced. Under these new relations of power, managements hope to be able to introduce new production concepts (Marsden et al., 1985). The new production concepts, however, require a measure of mutual trust and co-operation that does not fit traditional British industrial relations and the confrontational strategies chosen by the government and managements have only confirmed these traditions. In the United States, car manufacturers negotiated with the United Auto Workers (UAW) and both parties showed an unexpected ability and willingness to try out new possibilities and new contractual arrangements. This has resulted in some major changes in the industrial relations system (wage concessions, a major reduction in the number of job classifications), which could be reached in a much more consensual way than in Great Britain (Katz, 1985).

In both anglo-saxon countries we find a tendency to adopt the Japanese model and change the industrial relations system. In countries like West Germany and Sweden on the other hand, we find a tendency to work with the existing institutional framework and adapt the production model. In West Germany, job security and wages were not closely tied to a Fordist model of production organization with narrowly defined jobs. Consequently, workers and unions had less reason to consider management's initiatives concerning work organization as a direct attack on their positions. The changes in work organization that management considered necessary, could either be introduced unilaterally or formally agreed to without much upheaval through the existing bargaining mechanisms. In this respect, the West German industrial relations system turned out to be more flexible than the British or American system. Streeck $(1986,1988)$ has pointed out that, somewhat paradoxically, this flexibility arises from a system with a strongly formalized structure in which state legislation (co-determination) plays an important role. Legal (status) rights of employees, enforced by the state, make it easier for workers and unions in these countries to negotiate about changes in the organization of work, even in periods of high unemployment when unions are weak. The absence of such status rights for workers, especially in the field of co-determination, seems to have caused major competitive disadvantages for the car manufacturers in Great Britain and the USA.

Of course, the industrial relations system is only one element of the social and institutional context, in which the car manufacturers have to operate their plants. 
Other important elements are the national systems of education and vocational training, government industrial and technology policies, labour market institutions, traditional attitudes towards work, etc.. In view of all these peculiarities of the various production locations, the suggestion that production concepts can be transferred from one country to the other unmodified seems to be highly naive. Managers who nevertheless try to do so, may achieve some improvement in plant performance, but in all likelihood this performance will fall short of the foreign model. They may even be confronted with lower performance levels. The notion that a social context can be adapted at will to a given production concept is, of course, even further removed from reality. In actual practice, both the production model and the social context will change in interaction with each other. It can be argued that it belongs indeed to the essence of entrepreneurship to find a balance between socially acceptable, and therefore effective, changes in the institutional context and improvements in the organization of work on the shop floor.

\subsection{The German/Scandinavian model}

In Germany and the Scandinavian countries, efforts to improve productivity and product quality have naturally taken note of the Japanese example, but the willingness of all parties to move within the framework of existing institutions has created the setting for a quite distinctive approach, which is more in line with national institutions and traditions. At the institutional level this 'German/Scandinavian model' is characterized by the existence of legal rights of co-determination for works councils and organized workers and more generally by a relatively strong involvement of unions and workers at all levels of decision making (Barber/Lansbury, 1987). It should be added that unions and works councils usually exercise their rights with an equally traditional sense of responsibility and self-restraint. Another important institutional element is the well-functioning system of education and vocational training in these countries, which guarantees a steady supply of well-trained workers.

At the plant level the 'German/Scandinavian model' is characterized by the influence of socio-technical thinking, which is completely absent in the Japanese model. Thus, we find in the German and Scandinavian plants intensive efforts to uncouple labour from the motions of machinery and to introduce stationary work places (usually based on the use of automatic guided vehicles) with longer work cycles, whereas in Japanese plants, the dominant model is short-cycled, machinepaced labour on the continuously moving assembly line. The most extreme example of this movement away from the Fordist assembly line is the new assembly plant of Volvo in Uddevalla, where a small group of workers is assembling a complete car on one spot.

In the German and Scandinavian plants there is a clear tendency to diminish the use of unskilled and semi-skilled production workers and instead have direct production workers, who have completed vocational training in the regular educational system. This can be compared with the situation in Japan, where workers receive quite extensive in-house training. An important difference is the larger possibility for German and Scandinavian skilled workers to move on the 
external labour market, whereas in Japan workers are largely restricted to the internal labour market. The tendency of rising skills for production workers is wide-spread in the automobile industry. The motor vehicle manufacturers in the Netherlands for instance are following the same line. In co-operation with regular training institutions, they have recently created a new apprenticeship course for automobile assembly worker, which used to be at most a semi-skilled job. Where the regular system of vocational training is less well-developed, firms are forced to develop more in-house training.

The higher level of training is necessary because workers are no longer expected to carry out just one simple task. More and more they are expected to assist each other, to be able to switch frequently to different tasks, to inspect the quality of their own work and even to carry out routine maintenance work. The increasing levels of mechanisation in all parts of the car plant and the consequently rising costs of machine breakdowns and interruptions of production have increased the importance of well-trained and well-motivated production personnel. Frequently, production workers are now organized in teams. In German and Scandinavian plants, however, the meaning of team work differs considerably from the team concept that is prominent in Toyotism. In the European plants teams are meant to be semi-autonomous groups, that are able to carry out a specific set of tasks on the basis of their own planning and internal decision making. In the Japanese plants the teams lack autonomy and function primarily as vehicles for social discipline and control.

\subsection{Conclusion}

The competitive successes of the Japanese automobile manufacturers have been investigated by all their competitors. Each of them wants to learn 'Japanese lessons'. Especially the methods of production organisation developed at Toyota have attracted attention and the Toyota Production System has become a model for manufacturers all over the world. The argument of this paper is that efforts to introduce this model in other countries will at best meet with only limited success as long as managements fail to take adequate account of the social context in which their plants are operating. ${ }^{4}$ Furthermore, there is no reason to assume that 'world class' standards can be achieved only by following the precepts of Toyotism. In fact, it is one of the basic understandings of Toyotism as developed by Ono Taiichi that there is always room for further improvement. It is therefore within the logic of the model itself that the introduction of Toyotism in other countries will lead to different adaptations and new varieties. The quality of managements in car plants becomes visible, not in their willingness to adopt Japanese methods, but in their ability to apply and adapt these methods in a different social context and to manage the concurrent processes of social and institutional change.

\footnotetext{
4The fact that Japanese 'transplants' in the United States and Great Britain seem to function quite well, does not necessarily argue against this point. Apart from other reasons that may explain their productivity (greenfield plants with hand-picked personnel), these plants are most likely to be led by managers who are very much aware of the fact that they are operating in a non-Japanese environment that requires special efforts of adaptation and integration.
} 
So far, it is only in Germany and the Scandinavian countries that the competitive process in the automobile industry has led to the appearance of a production model with features that differ significantly from Toyotism as well as from Fordism. Like Toyotism this model is rooted in the social context of these countries and it remains to be seen, if it can serve as a model for other countries. In that respect much will depend on the competitive performance of the West German car manufacturers in the coming years, and especially on the performance of the German-owned manufacturers. If they succeed in staving off the present onslaught of the Japanese manufacturers, the German/Scandinavian model may become a source of inspiration for other manufacturers, especially in the other European countries. It is not impossible, however, that these 'German lessons' are learnt quicker by the Japanese manufacturers than by the Italian, French or British manufacturers. 


\section{PART III}

New rules:

The automobile industry and institutional analysis 



\title{
9. New rules for the automobile industry?
}

\author{
9.1 Automotive paradise: a retrospective view \\ 9.2 Paradise lost \\ the consumer revolt \\ workers revolt \\ new technologies \\ the oil crises \\ 9.3 Car wars \\ 9.4 The Japanese production system \\ just-in-time \\ 9.5 The industry context \\ supplier relations \\ industrial relations \\ 9.6 The new rules of the game
}

The preceding chapters have dealt with various aspects of the crisis of Fordism in the automobile industry. This chapter provides first a synthetic overview of that crisis and then focuses on current debate concerning the future of the industry. At the center of that debate stands 'the Japanese production system', a source of inspiration, a model to follow, a moving target, a real phenomenon with mythical proportions. The Japanese challenge is the culmination of a long series of challenges that the traditional Fordist production system has had to face since the late 1960s: revolting consumers and workers, oil crises and new demand patterns, new regulations and new technologies. The Japanese production system is now presented to the traditional Fordist car manufacturers as a chance to overcome the crisis of Fordism, as a coherent set of new rules for the industry.

\subsection{Automotive paradise: a retrospective view}

After World War II passenger car production, that had stopped almost completely to make room for the production of military vehicles, was quickly resumed in all the major car producing countries. By 1950, production was already above the prewar levels in both North America and Western Europe. In that year, the North American industry alone was responsible for more than $85 \%$ of world passenger car production (Table 9.1). Obviously, this predominant position of the Americans in world production was untenable as soon as the European countries had recovered from the damages of war. By the end of the 1960s, the European car manufacturers' share of world production was at $40 \%$, just about the same as that of their North American counterparts. 
In those twenty years world production of passenger cars had more than tripled from about eight million to over 25 million. These decades saw the world-wide diffusion of the American model of mass production. Everywhere, car manufacturers tried to implement the lessons that Ford had taught them. Of course, conditions were different in various countries and Fordism consequently developed into various configurations. The basic elements were all there: specialized machine tools, the moving assembly line, Taylorist methods of work analysis, but they were used with varying intensity, depending on such circumstances as the size of the market, the supply of skilled and unskilled labourers, the level of wages and industrial relations.

The introduction of Fordist production methods had started in Europe already in the 1920s. Especially the French and Italian automobile builders like Citroën, Renault, Berliet and Agnelli were fascinated by Ford's model and inspired by his enormous successes. Ford in his turn was very open about his methods and provided both the press and his competitors extensive information about them. The European car markets remained much smaller, however, than the North American market, which limited the applicability of Ford's methods. With small production series, neither Ford's levels of mechanization nor his high wages were feasible. At lower levels of mechanization, 'scientific management' was more difficult to achieve. In their machining shops, most European manufacturers maintained some kind of piece rate system. By doing so, they left the workers with some control over work methods and work speed (Tolliday \& Zeitlin 1986).

After the war, some of these departures from the original Fordist model survived even after production had increased in volume. Managements didn't bother to come closer to the ideal model as long as the market was growing and they were selling whatever they could produce. Besides that, unions had quickly become an established part of the industrial order of post-war Europe. Piece rates were a permanent bargaining object for the unions. Employment levels could be defended by means of traditional craft-related job demarcations, that provided 'job control'. In the course of time, however, industrial unionism came to accept the Fordist production system in exchange for high wages. Inefficiencies that dated from preFordist times were most difficult to eliminate in the country where traditional trade unions (and equally traditional managers) resisted the logic of the Fordist production organization: in Britain. Only in the early '70s did British Leyland effectuate the change from incentive-based wages to the 'measured day work' system (Lewchuck 1986). In other words, it began to introduce some basic elements of Fordism at the same time that other firms had reached the limits of that system and began to search for other methods.

In the early post-war years, each of the major European countries still counted several car manufacturers, but in the following decades a process of concentration took place, comparable to what had happened in the United States in the 1920 s. By the early 1970 s, each major country had only one or two passenger car manufacturers left: Volkswagen (including Audi) in Germany, Renault and Peugeot (including Citroën) in France, Fiat in Italy and British Leyland (including Rover) in the United Kingdom. These concentration processes, however, had taken 
Table 9.1

Regional Structure of Passenger Car Production

\begin{tabular}{|c|c|c|c|c|c|}
\hline Year & Total & $\begin{array}{l}\text { USA + } \\
\text { Canada }\end{array}$ & $\begin{array}{r}\text { Western } \\
\text { Europe }\end{array}$ & Japan & $\begin{array}{r}\text { Other } \\
\text { Regions }\end{array}$ \\
\hline \multicolumn{6}{|c|}{ Cars (1000s) } \\
\hline 1937 & 5009 & 4069 & 899 & 5 & 36 \\
\hline 1950 & 8179 & 6951 & 1110 & 2 & 116 \\
\hline 1957 & 9786 & 6460 & 3024 & 47 & 255 \\
\hline 1964 & 17113 & 8305 & 7284 & 580 & 944 \\
\hline 1971 & 26157 & 9666 & 10624 & 3718 & 2149 \\
\hline 1978 & 31917 & 10320 & 11321 & 5976 & 4300 \\
\hline 1985 & 32047 & 9263 & 10577 & 7603 & 4604 \\
\hline 1989 & 35930 & 7807 & 13728 & 9052 & 5343 \\
\hline \multicolumn{6}{|c|}{ Shares (\%) } \\
\hline 1937 & 100 & 81.2 & 18.0 & 0.1 & 0.7 \\
\hline 1950 & 100 & 85.1 & 13.6 & 0.0 & 1.4 \\
\hline 1957 & 100 & 66.0 & 30.9 & 0.5 & 2.6 \\
\hline 1964 & 100 & 48.5 & 42.6 & 3.4 & 5.5 \\
\hline 1971 & 100 & 37.0 & 40.6 & 14.2 & 8.2 \\
\hline 1978 & 100 & 32.3 & 35.5 & 18.7 & 13.5 \\
\hline 1985 & 100 & 28.9 & 33.0 & 23.7 & 14.4 \\
\hline 1989 & 100 & 22.1 & 37.2 & 25.6 & 15.1 \\
\hline \multicolumn{6}{|c|}{ Compound Yearly Growth Rates (\%) } \\
\hline $1957 / 71$ & 7.3 & 2.9 & 9.4 & 36.6 & 16.4 \\
\hline $1971 / 85$ & 1.5 & -0.3 & 0.0 & 5.2 & 5.6 \\
\hline $1985 / 89$ & 2.9 & -4.2 & 6.7 & 4.5 & 3.8 \\
\hline
\end{tabular}

Source: Hild (1986), Table 2; VDA, Das Auto international in Zahlen, various years, own calculations.

place almost exclusively within national boundaries. Europe remained divided into a number of national markets that were still too small to exploit fully all the advantages of mass production. This may help to explain why the American manufacturers continued to improve their mass production methods, while the European manufacturers remained more active in the field of product development. The Americans treated the automobile as a 'mature' product that could be changed in appearance, but that would remain technically the same. Consequently, they developed a product renewal routine based on yearly changes 
that would only go 'skin deep'. It was even said that they refrained from improving the quality of the car in order to shorten its useful life: planned obsolescence. In Europe, the interest in improving quality and performance of the automobile remained much more alive. This was visible not only in the number of automotive patents taken out in Europe, compared to the US (Altshuler 1984, p.104), but also in the survival of a substantial number of so-called specialist producers like Jaguar, Lotus, Saab, Lamborghini, Alfa Romeo, Mercedes Benz, BMW, Volvo, Porsche, Ferrari, etc. These specialists, producing only for the upper market and sports segments, introduced a large number of product innovations that later trickled down to lower market segments. Altogether, the European automobile industry showed more technological dynamism but lower productivity than the North American manufacturers. This can even be maintained for the subsidiaries of the American manufacturers in Europe. Already well established before the war, the subsidiaries of Ford and General Motors (Opel/Vauxhall) acquired a distinctly European identity. The main operations of both firms were (and are) located in Britain and Germany, with Ford having a more British profile, later also establishing its European headquarters in Britain, while General Motors became rooted more strongly in Germany (around the Opel marque). Abernathy (1978) argues that the North American car manufacturers had been so single-minded in their quest for high productivity that they had all but lost the ability for product innovation. As long as there were no major product innovations coming up this didn't create significant problems. As we shall see, however, in the 1970s possibilities for product innovation multiplied as a result of the so-called micro electronics revolution. The technically versatile, but less productive European car manufacturers seemed better positioned to take advantage of these new opportunities. Thus, having progressed so far along the road of Fordist production techniques became a drawback for the North American producers when new possibilities appeared for product innovation.

Before taking a closer look at the various challenges to Fordism that appeared in the late 1960 s and multiplied rapidly in the course of the 1970s, it is necessary to mention the development of the Japanese automobile industry since the end of the war. Almost unnoticed at the time, Japanese passenger car production had grown from almost nothing in 1950 to 3.7 million in 1971. Western observers found Japanese cars to be small, technically unsophisticated and ugly. The Japanese had little tradition in the development and design of cars and much of their early models was based on licencing agreements with Western car manufacturers and on reverse engineering. Just as the car manufacturers in other countries, they were eager to apply Fordist mass production methods. All through the fifties and sixties, however, their production volumes were even lower than those of the European industry. Consequently, just as in Europe, Fordism in Japan again developed into a specific local configuration. Without the European capacity for product innovation, all attention went into the improvement of efficiency at much lower levels of production than in the other car manufacturing countries. The result was an industry that by the beginning of the 1970s was ready to challenge the North American champions of Fordism at their own specialty: productivity. 
Slowly at first, but then at an increasing speed cracks were appearing in the Fordist production machine. What went wrong? Where did decline begin? Some say that the American car manufacturers had become spoiled by their own success. They had become slow, fat and sloppy, their products ugly, oversized and of bad quality. Others point to the coming of age of a new generation of workers, better educated and without memories of the economic crisis of the 1930s. These workers were less suitable for the high speed assembly lines of Henry Ford than the earlier generations of immigrants and farmers. Others again point to changes that occurred in international power relations, resulting among other things in the 1973 oil crisis and the subsequent rise in prices of oil and raw materials. Even though oil prices went down after some time, the automotive industry was never the same again. Another challenge frequently mentioned is the micro-electronics revolution, the coming of cheap computing power, programmable machinery, robotics, and sensorics. They allowed for new methods of production and production planning, new levels of automation that Henry Ford could only dream of. And then, of course, there were the Japanese, who seemed to have an answer to all these problems.

In the early seventies, even before the oil crisis, criticism of the 'automotive system' had reached politically relevant proportions, especially in the U.S.. The car and its manufacturers were being accused of destroying the environment, using up scarce resources, not just oil, but also capital and space, carelessly endangering human lives and wasting human energy and ingenuity in its production processes. The ensuing sense of crisis was admirably summarized in Emma Rothschild's book 'Paradise Lost' (1973), that prophecied 'the decline of the auto-industrial age'. A decade later, an important international study on the automobile industry also raised the question of 'The Future of the Automobile' (Altshuler et al. 1984). By that time, however, it had become clear that the auto industry had not entered an era of decline: "..the capacity of the world's automakers to deal creatively with the most pressing energy, air-quality, and safety challenges is great, and urban traffic restrictions will not discernably affect aggregate motor vehicle sales or volumes of travel." (Altshuler et al. 1984, p.107) What had been proclaimed as a crisis of the automobile turned out to be a crisis of the way automobiles were designed and produced. It was a crisis of the Fordist production system.

\section{the consumer revolt}

Was it the beginning of the end of the era of mass production, when consumers started to complain about the product? There had been some rumblings when the American 'Big Three' (GM, Ford and Chrysler) started their practice of yearly model changes, inducing status-conscious customers to buy a new car before it was technically necessary. Most of these model changes only concerned the outer wrappings of the cars, which were getting bigger and heavier, but not better. 'Planned obsolescence' was the name of the game and not everyone liked it. However, in the years of plenty this type of criticism remained of limited importance. Things changed dramatically when the issue of safety was raised. In 
1965 Ralph Nader published his now famous indictment of the American car manufacturers under the title 'Unsafe At Any Speed'. Nader attacked the lethal instability of the Chevrolet Corvair. According to his account, GM's engineers knew about this, but they had been unable to overrule the stylists and the cost accountants. The Corvair, just like the Vega that came under attack later on, was an import fighter directed mainly against Volkswagen and had to stay cheap in order to be effective as such. The logical conclusion that Emma Rothschild draws from this episode is that " $(t)$ he causes of auto unreliability have to do with the character of modern mass production, where complex products are manufactured in an atmosphere of unremitting cost efficiency." (1973, p.87) Cost efficiency is seen as something that is detrimental to quality. Cost competition, in other words, had lethal consequences for the consumer. Emma Rothschild was not the only one to draw this conclusion. Even in a country with a traditionally non-interventionist government, this was a clear reason for intervention. The long term effect of Nader's contribution was a wave of increasingly strict regulations that hit the industry with considerable force. These regulations concerned safety, later also fuel efficiency and exhaust emissions. They forced the car manufacturers to enter new fields of technology and to engage in research and development. Similar regulations were also introduced in other countries, although sometimes much later. American regulations were generally most severe and the American manufacturers had to invest considerably into meeting them.

It has been argued by opponents of regulation, that this has led to underinvestment in other important fields of technology and that regulation therefore contributed to the decline of competitiveness of the American manufacturers in relation to the Japanese and Europeans. The point is difficult to prove, but to the extent that U.S. regulations were more difficult to meet for large cars than for small ones, the Japanese clearly enjoyed an advantage. The real problem, however, was that mass production in the North American version had somehow become associated with low quality. As we shall see below, this hadn't been the case in Japan, where mass production had become organized around the notion of 'total quality'. In the traditional Fordist system, quality had its price: it meant more inspectors, more repair and lower output. After the Japanese had proven that 'quality is free', American quality experts, who had been preaching that message for years, finally found a hearing in their own country. The result has been a steady increase in quality of Big Three products throughout the 1980s.

In Europe, there was no similar debate about the safety of small cars. In the first half of the 1990s American safety and emission standards are still more strict then European ones. The European specialists, however, increasingly manifested themselves in the course of the 1970 s as champions of safety (at considerable speed), durability and quality. Their products appealed to status-conscious consumers in the United States, for whom the Japanese products were too cheap. Prices didn't really matter very much as long as the dollar stood high enough. Therefore it didn't matter that high quality had been achieved sometimes rather inefficiently, with a large quality control staff, a lot of repair work and craftlike methods that reminded of the pre-Ford era. Although not always leading the world, the European specialists incorporated important new technologies in their 
products throughout the 1980s. The North American market offered ample opportunities for this pleasant mixture of solid craftmanship and high technology. Whereas European exports to the U.S. consisted mainly of small cars (Volkswagen) in the early 1970 s, a decade later they consisted mainly of large and expensive cars. So, by the end of the 1970s the American manufacturers faced the formidable task of re-inventing the small car while at the same time defending their positions in the large and medium-sized range against attacks from below (Japan) as well as from above (Europe).

\section{workers revolt}

If it wasn't the consumer revolt, then surely it was the workers' revolt that raised the question if Fordism had a future in the car industry. Automobile workers played an important role in the big strike movements that shook Europe in the late 1960s. These strikes were widely interpreted as a sign of disaffection with the quality of work in the mass production factories. In past decades, the unions had learnt to translate complaints about the quality of work into demands for higher wages and other compensations. Now they were severely criticized for neglecting the health and safety of their members, for acquiescing to the degradation of work and disregarding the possibilities for improving the quality of work. A new generation of workers had arrived into the car plants, a generation that had not experienced the hardships of crisis and war. These workers were less inclined to accept the tediousness of assembly line work as a fact of life. They took for granted the wages and the standard of living that their parents had considered a just compensation for toiling in the Fordist system. They were often better educated than their parents and very conscious of the gap between what they could do and what was required of them. In the United States, these differences between generations were reinforced by the seniority system that had been bargained out between employers and the United Auto Workers (UAW). This system ensured that in case of a downturn in the market, the persons with the shortest employment record would be dismissed first ('last in first out'). ${ }^{1}$ Obviously, workers with low seniority have less to lose than workers with twenty years on their record. In Europe, car manufacturers had never resorted to the same extent to the 'hire and fire' policies that their American counterparts used to deal with the irregularities of the market. Partly this was also due to legislation that gave workers some protection against dismissals. Consequently, the generation gap was not reproduced in a division between workers with high and low seniority. In the European labour movement, the youthful protest served to revive some old programs and demands that had been muted by the victory of Fordism in the 1950s.

Before protest broke into the open, it had been visible in such things as absenteeism, labor turnover, product quality and shopfloor conflicts. In a position

\footnotetext{
${ }^{1}$ This can lead to substantial reshuffling of jobs in case of dismissals. The workers dismissed may have had jobs that are not eliminated. Persons with higher seniority will than be called upon to do these jobs. It is a system that is typical for a production system where jobs are so simple that workers have become completely exchangeable.
} 
paper produced by General Motors for the 1970 contract negotiations with the UAW, management complained about increasing "tardiness, loitering, failure to follow instructions, and abuse of employee facilities", especially of the sickness and accident benefit program. Workers reported ill more often and recovered more slowly. Moreover, they reported more often "strains and sprains and nervous diseases", that were more difficult to diagnose (quoted by Rothschild 1973, p.125). Two years later, these individual silent signs of protest turned into a strike that attracted nationwide attention. In february $197297 \%$ of the workers of the GM plant in Lordstown, Ohio voted in favor of a strike to improve working conditions. The strike lasted for three weeks. It received a lot of coverage from the press, because in the years before GM had put forward exactly this plant as its vision of the future. In 1970 the plant had been modernized and stuffed with the latest computerized technology (e.g. 26 Unimate robots for welding and paint spraying) to produce the Volkswagen-fighter Vega. It is ironic that this plant, which apparently harbored already some of the technology that would change the face of the industry in the following decade, would become a symbol of resistance against old-fashioned Fordism. On account of Rothschild's description of the strike, it seems that the strike resulted from the fact that management resorted to strict discipline and speedup when the new technology didn't perform as expected. In the national press, at least, the strike was depicted as a strike against "assembly line monotony" (Wall Street Journal) and a call for restauration of the "primacy of man" in production (New York Times; all quotes in Rothschild 1973, p.17).

To the credit of General Motors it must be said that over the past decades it has been engaged more than any other car manufacturer in an active search for alternative forms of organization, other management styles and different relations with the unions. At the time of the Lordstown strike, GM was already running a program of Organizational Development (OD) aimed at the managerial and salaried ranks. OD was an anti-Taylorist approach that criticized the disregard for the capacities of workers to share responsibility and to think about their job and how to do it better. In 1973, the OD program was enlarged and elaborated on the basis of an agreement between the UAW and GM. A GM-UAW National Quality of Work Life Committee was created that supported the development of an enterprise-wide Quality of Work Program (QWL) in the following decade. Aim of the program was to create a more satisfactory work life, which would then result in a reduction of absenteeism and turnover as well as in higher quality products (cf. Landen \& Carlson 1982). GM also experimented with so-called team-based plants (Cherry 1982) and pay-for-knowledge schemes, which reward workers for their knowledge, regardless of the job they are currently carrying out, but with the understanding that that knowledge will of course be available to the firm by means of job rotation, mutual support and team work (Scheinecker 1988).

Similar developments could also be noticed in Germany, where a new coalition government of social-democrats and liberals initiated a large research program on the 'humanization of working life' in 1974, which involved support for experimental redesign of workplaces and production lines (Dankbaar 1987). Firms that wanted to participate were required to involve their workers and union representatives in the project. Already in 1973, the metal workers union IG Metall, which also 
represents the automobile workers, had after a week of strikes concluded a framework contract with the employers of the important region of Nordwürttemberg-Nordbaden. This contract for the first time arranged for some control of the workers over standard setting; it called for minimum tact times of 1.5 minutes and prohibited further shortening of existing tact times. Moreover, it was agreed that a humane design of jobs was desirable and that job enrichment and job enlargement were important means to achieve those ends. Further elaboration of the agreement was left to the works councils of the individual firms. Significantly, some of the earliest projects of the Humanization program were carried out in the automobile industry. Automotive supplier Bosch reported on an experiment with workplaces that were uncoupled from the assembly line and Volkwagen carried out a group work experiment in an engine assembly shop. These experiments, although they often didn't survive the duration of the project, gave managements and union practical insights into the potential and limitations of non-Taylorist forms of work organization. There is a substantial continuity in thinking from these early experiments to the various forms of group work described above (Chapter 5) and more recent efforts to introduce team concepts on a massive scale in the German automobile industry (Minssen et al. 1991).

None of these projects went as far as the Swedes. Volvo created a world-wide sensation by the presentation in 1974 of its new assembly plant in Kalmar, which was based on the insights of another prominent anti-Taylorist tradition: the sociotechnical systems approach. The socio-technical systems approach (STS) had developed in Great Britain in the late 1940s. It argued that every production system consists of a technical and a social subsystem. The organization and interaction of both subsystems contribute to the success of the production system and they bave to be jointly optimized. The Taylorist tradition was accused of neglecting the role of the social system in its search for productivity. The main vehicle of joint optimization that the STS approach developed was the (semi)autonomous working group. Instead of concentrating on the determination of individual tasks the STS approach designed work packages for groups of workers that could regulate their internal division of labor. By handing over responsibility to these groups, it was argued, the organization would be more flexible, less planning activities would have to be carried out by expensive staff far away from the shopfloor and workers would be better motivated. The motivational aspect was no doubt an important consideration for Volvo's management when it decided on the Kalmar plant. Absenteeism and high labor turnover had been (and still are) a perennial problem for the Swedish car industry.

In the Kalmar plant, assembly work was organized around stationary work stations, where groups of workers carried out part of the assembly process. The car bodies were moving from one station to another on automated guided vehicles. The continuously moving assembly line was thus eliminated. The assembly process had as much as possible been divided up into coherent sets of activities, that became the responsibility of individual groups. Inside these groups, consisting of 15 to 20 persons, workers could rotate over different jobs. Work cycles were about 25 to 30 minutes. The groups were also responsible for quality and for simple maintenance work. Even the architecture of the plant was emphasizing the principle of group 
work with separate entrances and rest rooms for each team. Since 1974 some changes have been made to the organizational design of the plant, but the main principles were maintained. In the mid 1980s the Kalmar plant was the most efficient plant of Volvo in Sweden. It remained a controversial plant, though, both with managements, who preferred a tighter control over labor, and with workers, who found the improvements in the quality of work insufficient. As the labor market became very tight in the second half of the 1980 s, absenteeism increased rapidly. After experiments with other concepts and extensive evaluations, the Kalmar concept was taken up again and further elaborated in the new assembly plant of Volvo in Uddevalla. Production started there in 1989. The plant consists of 6 separate factories, each containing four workshops with four assembly stations. In principle, it is possible to assemble a complete car in each assembly station, so that 96 cars can be assembled at the same time. Of course, this requires that the working group at the assembly station is capable of assembling a complete car. Required training would be about at the level of a car mechanic. Alternatively, each working group in a workshop could do $25 \%$ of the assembly work. The Uddevalla plant has attracted worldwide attention and is just as controversial as the Kalmar plant in its days (cf. Auer \& Riegler 1988; Berggren 1991).

As we will see below, the Japanese production system also emphasizes the importance of team work. It would not be correct, however, to treat the Japanese team concept under the heading of the workers' revolt. The introduction of group work in Germany, Sweden and in some General Motors plants occurred in reaction to worker protest, resorted to anti-Taylorist theories and methods, and evolved often in close cooperation with the unions. The Japanese team concepts on the other hand were developed on the basis of traditional Taylorist thinking and predicated upon the defeat of industrial unionism in the early fifties. Consequently, in the Japanese approach the concept of autonomy as an important attribute of the group is absent and the group is basically used to eliminate the waste resulting from the inevitable imbalances between individual standard times (a function that is of course also present in socio-technical group design).

\section{new technologies}

The micro-electronics revolution also posed challenges for the traditional Fordist arrangements. To start with, it provided numerous opportunities for product innovation. The use of these opportunities was greatly encouraged by the growing number of regulations concerning safety, fuel consumption and emissions. In the mid 1970s, microprocessor controls were added to engines, to be followed by more microprocessors in transmissions and suspensions in the course of the 1980s. Microprocessor-controlled anti-skid braking systems that had initially been developed for airplanes came to be adapted for cars. New impact and acceleration sensors allowed for the instantaneous assessment of situations and the construction of passive restraint and traction control systems. New plastic and composite materials were introduced to deal with crash test requirements without raising the weight of the vehicle. Technologies that had been on the shelf for many years came to life under the pressure of regulatory action and increased competition: diesel, fuel injection, turbo-chargers, aerodynamics, front-wheel drive. After 
decades in which the basic technical contents of the car had changed relatively little, a series of new functions were introduced. A mechanic from the 1920 s would not have had many problems in understanding the functioning of an ordinary 1970 model. By the end of the 1980s, even cheap small cars were full of microprocessors, and the same mechanic would be at loss looking under the hood of any one of these models.

As noted above, the American manufacturers found it far from easy to engage in major acts of product innovation. They had concentrated for a long time on the improvement of productivity along the lines of mass production and had unlearnt the art of product innovation (Abernathy 1978). They were also handicapped by the fact that they had followed Henry Ford's lead and produced a large part of their parts and components in-house. Now that new technologies had to be incorporated into these parts, the American manufacturers had to find ways of mastering all these technologies themselves. This was one of the reasons the Big Three acquired interests in aerospace and defense firms, as these were the firms that were supposedly familiar with advanced technologies. The Europeans not only had a stronger tradition in product innovation, especially the specialists, but the industry also counted a larger number of independent component producers that were capable of doing their own R\&D, providing a broader basis for automotive innovation. The Japanese, finally, increased their spending on automotive R\&D tremendously. In 1975 Japanese firms already took out more automotive patents in the United States than US firms did. Two years later, they also overtook the German manufacturers on this count.

Product innovation and the new emphasis on quality changed the character of competition in the automobile industry. All major manufacturers had to invest considerably in order to acquire the necessary technological capabilities. What counted in the end, however, were not these capabilities as such: all major actors were and are able to implement advanced technologies and to produce high quality products. What counted were the speed of implementation and the costs of producing high tech, high quality products. In a recent study, Clark and Fujimoto (1991) have shown that the Japanese car manufacturers have developed some development and design practices that have allowed them to realize appreciably shorter and far more efficient product development processes than their Western competitors. With shorter lead times they could react more quickly to new technological opportunities and changing consumer preferences.

Development practices also differ in their attention for manufacturing efficiency. In fact, there seems to be much more interaction between product development and the manufacturing process in Japanese enterprises. Ease of manufacturing is a constant point of attention in the development process and inputs from manufacturing departments into the development process are a regular and integral part of that process. In the $1970 \mathrm{~s}$, the interaction between development and manufacturing did not receive much attention in Europe and North America (with the exception of Abernathy (1978)). In what may be called a typically Fordist inclination, attention was focused on the opportunites for improving the efficiency of the production system. The Americans were the first to introduce programmable 
robots in their production lines (mainly for paint spraying and spot welding). Programmable machines offered clear advantages over the dedicated equipment that had been used in earlier efforts at mechanization. The latter kind of machines had to be scrapped almost completely when there was a model change. The new robots would only have to be reprogrammed. The speed of technological change in the early period, however, was such that the robots would be outdated by the time a new model arrived. A potentially more important advantage was the possibility to run different models with differently sized bodies over the same line. The robot would recognize the model and treat it according to the relevant program. This kind of flexibility, however, required major changes in the organization and planning of production. In the traditional Fordist system there was a separate assembly line (and a separate plant) for each model and in most cases robots were not really used for flexibility. Moreover, the workers with their highly fragmented jobs and low level of skill were not able to deal adequately with these complex machines.

As we shall see below, the Japanese production system had developed in a different direction and had already introduced mixed product lines and multi-skilled workers before robots became technically feasible. The Japanese had always introduced all kinds of simple devices and mechanisms to simplify work, control quality and speed up production. By the late 1970s, it was said that they were far ahead of the rest of the world in the use of robotics. On the spot investigations of these rumors by large delegations of automotive managers showed that the Japanese had not developed more advanced technology than the Americans or Europeans. They had implemented many simple and partial solutions that were not spectacular from a technical point of view but that helped them along a diffusion and learning curve, while the American and European engineers were still working on the construction of far more complete and therefore far more complex automatic installations. These large projects took more time than expected and ran into a lot of difficulties, causing high costs before they worked more or less satisfactorily. More often than not this was a consequence of the Fordist lack of communication between engineering departments and production workers. Meanwhile, the Japanese manufacturers are also building highly automated production installations in response to a tightening labor market. It would seem that through their piecemeal, trial and error approach they have acquired the capability to do so far more cheaply than their American and European competitors.

Only slowly did it occur to the traditional Fordist producers that the new equipment did more than eliminate some workers: it changed the structure of the workforce, which required a new style of management, new training programmes and a new work organization. Figure 9.1 illustrates these changes over the first decade of robotization. It shows how within a ten year period spot welding was almost completely automated. The share of robot welds rose from $6 \%$ to $36 \%$ over 
Figure 9.1a

Mechanization on the body shop: the case of FIAT

Trend of Automation in Spot Welding

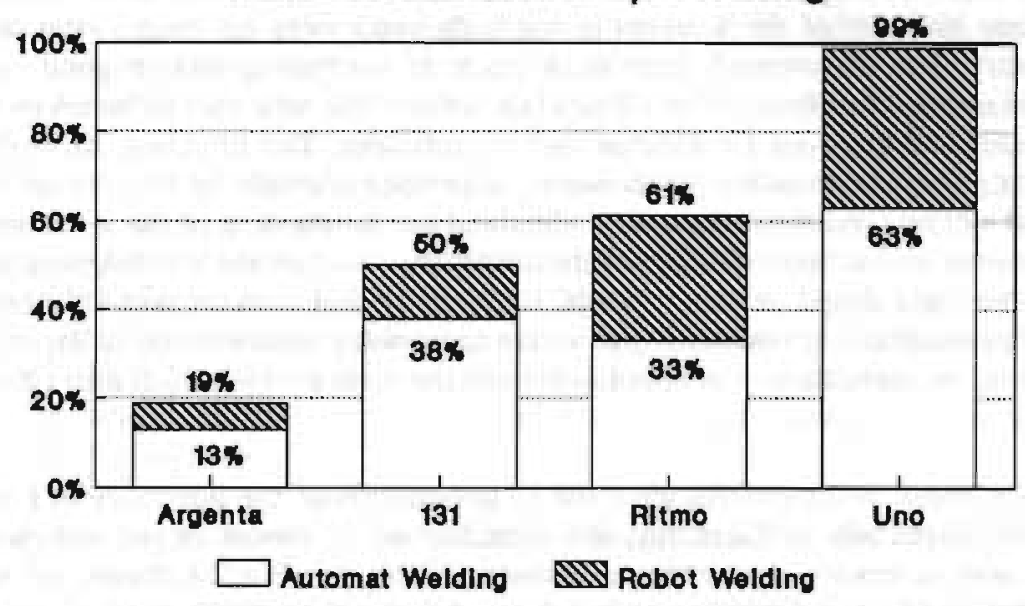

Source: Volpato 1984

Figure 9.1b

Mechanization in the body shop: the case of FIAT

Robogate and Conventional Welding

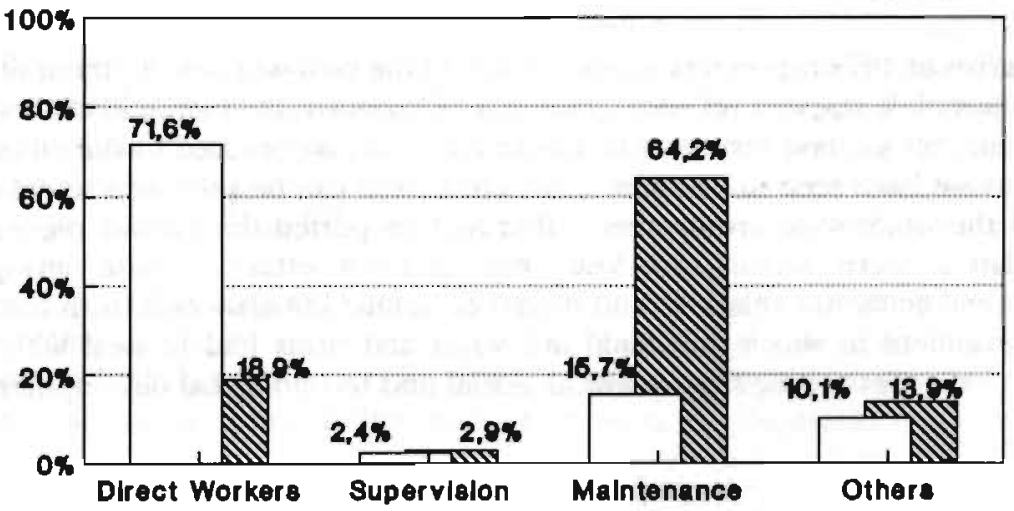

$\square$ Robogate Conventional Line

Number of Workers: Conventional Line $=247$, Robogate $=137$ 
that period. ${ }^{2}$ On the conventional line almost three quarters of the workers were direct production workers (usually semi-skilled welders). On Fiat's so-called Robogate line of 1982 less than one fifth of the workers were direct production workers, whereas two thirds were skilled maintenance workers. This quantum change over a short period was difficult to master with traditional Fordist methods. The large majority of the workers in the body shop were no longer attached to machinery that determined their work pace. If everything was in good order, workers only had to feed the machines (an activity that was also to be taken over by robots) and look out for failures and irregularities. The effective use of these complex automatic installations, however, depended crucially on the attentiveness of these workers, on their ability to understand the functioning of the installations, to intervene and correct quickly where necessary - and on their willingness to do so. These body shops, in other words, required skilled workers and cooperative industrial relations. In countries that where these were available, i.e. in Japan and Germany, the introduction of robotics caused the least problems (cf. also Chapter 6).

Logically, these developments gave rise to debates about the adequacy of Fordist methods. Especially in Germany, the introduction of robots in the automobile plants was a reason to continue debate about non-Fordist forms of work organization (Wobbe-Ohlenburg 1982; Kern \& Schumann 1984). It appeared that in the newly robotized and automated departments of the German automobile plants, new job profiles were developing for skilled operators of automated installations and around these, new forms of work organization. These 'new production concepts' were even extended to parts of production that had so far not been touched by flexible automation. An increasing number of skilled workers ('Facharbeiter' who had completed an apprenticeship) were working directly in production. The old Fordist division of labour between direct and indirect production workers was disappearing.

the oil crises

The oil crisis of 1973 represents a major break in the post-war development of the world automobile markets (cf. also Chapter 4). Obviously, the manifold challenges to Fordism that we have just described were not in any way caused by the oil crisis. In fact, as we have seen in Chapter 3, the crisis itself can be seen as a signal that some of the world-wide arrangements that had supported the Fordist regime of accumulation were starting to lose their positive effects. These changing international economic relations and macro-economic imbalances in turn formed the environment in which individual industries and firms had to deal with the specific challenges arising from political, social and technological development.

\footnotetext{
${ }^{2}$ Robots are not necessarily the cheapest form of automation. Dedicated equipment, moreover, is usually faster, because it can do many spotwelds simultaneously. If different car models have some elements in common, it may be possible to run them through a mixed line of dedicated equipment (doing the same operation on every car body) and robots (with different programs for different body shapes).
} 
Figure 9.2 clearly shows how world motor vehicle production (i.e. passenger cars and commercial vehicles) increased rapidly between 1953 (the end of the Korean War) and 1973. Since then, the pattern is more clearly cyclical and average growth much lower. In the United States, in fact, new car registrations have never again reached the 1973 level! The second oil crisis caused another downturn, so that world production in 1982 was well below that of 1973. After 1982, however, substantial growth has been achieved again, although the growth rates of the 1960s have not been duplicated (cf. Table 9.1). Behind this world-wide pattern lies the much more differentiated experience of the various national car industries. Figure 9.3 shows that the U.S. industry has been much more sensitive to cyclical ups and downs than the European industries. The patterns of development in Western Europe and the U.S. are relatively similar, however, if compared to the post-war history of the Japanese car industry, which is one of high and almost uninterrupted growth. The expansion of the Japanese automobile industry during and after the two oil crises made the experience of these crises quite different from that of previous downturns. For the first time, slow growth was accompanied by the rise of an additional supplier.

In the late 1960s and early ' 70 s, the rise of Japan as a supplier of cars to other regions of the world was only just beginning. Japanese export successes, mainly on the North American market, were seen as a confirmation of the maturity of the product, which made production in less advanced and low-wage countries increasingly feasible. Now that German wages were rising, it seemed only natural that other countries would overtake the Germans on the American market and offer cheap and simple cars to replace the Volkswagen Beetle. Then came the oil crisis of 1973 which caused prices of gasoline to rise rapidly. The reactions of the American consumers were predictable. Demand for small and fuel-efficient cars was suddenly soaring in a market that had always favoured large, comfortable 'gasguzzlers'. The Japanese were there at the right time with the right products to satisfy this demand. In view of the expansion of the demand for small cars, Volkswagen decided in 1974 to start production in the United States. The traditional American manufacturers had not much to offer in this market segment and became worried enough to start a major operation called 'downsizing'. This involved taking their large models as a starting point for the design of smaller cars. Such cars naturally had all the characteristics of a compromise and could not compete effectively with cars that had been designed as small cars from the start. In the second half of the 1970s however, American consumers seemed to opt again for large cars. American manufacturers wavered between leaving the small car market to foreign competitors or starting serious development efforts in this field. Then came the second oil crisis. Now it was obvious that small cars would remain important and that the American manufacturers had a long and costly learning process ahead of them, if they wanted to meet the Japanese challenge. ${ }^{3}$ The

\footnotetext{
${ }^{3}$ There are still various riddles that remain to be solved in the discussion on small cars and U.S. manufacturers. If it is true, as Altshuler et al. (1984) argue, that U.S. manufacturers succeeded twice in developing a small car reply to German imports as soon as these came above a certain sensitivity threshold (about $8 \%$ of the market), why couldn't they do so in the second half of the 1970s? Moreover, how is it possible that General Motors and Ford were able to
} 


\section{Figure 9.2}

\section{World Vehicle Production 40 years}

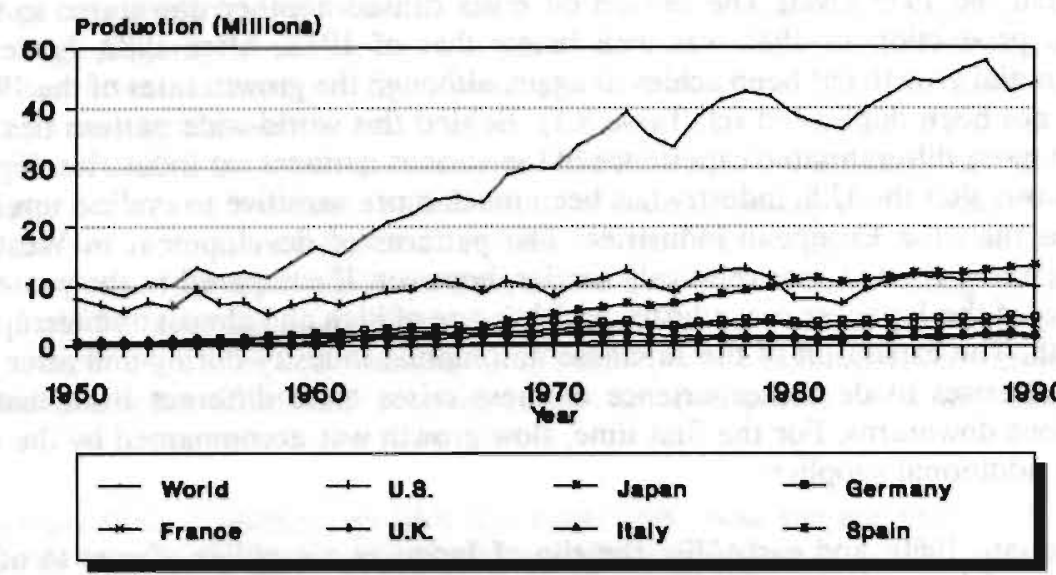

Source: Automotive News 1991

Japanese in the meantime had used the seventies to learn about the American market. They had made very large profits that were used to improve their products. Slowly but steadily, they were moving upmarket.

In Europe, the oil crisis didn't have such a dramatic impact on the structure of demand in the car market as in the United States. Gasoline prices had always been much higher in Europe than in North America and European manufacturers had always offered small and even very small ('supermini') cars to their customers. The Japanese manufacturers, moreover, concentrated their exporting activities in the 1970s mainly on North America and to a lesser extent on the smaller European countries that didn't have an indigenous car industry. That doesn't mean that nothing changed in Europe. In terms of industry structure, these were the years of consolidation after the national concentration processes. In terms of products, the European manufacturers were developing a wider variety of products, moving away from the single product line of previous decades. Especially for Volkswagen, the most successfull mass producer in Europe, the changeover from the Beetle, which had seen annual production volumes of more than 1 million units in peak years, to a more modern and diversified product line represented a tremendous change. In Europe, downsizing was not an issue. If anything, there was a movement in the opposite direction with passenger cars growing in size in response to rising incomes. By doing so, the European car manufacturers postponed the direct confrontation with the Japanese. They couldn't avoid the confrontation in the

develop and produce small cars in Europe, but not in the U.S.? 


\section{Figure 9.3}

\section{World Vehicle Production 40 years}

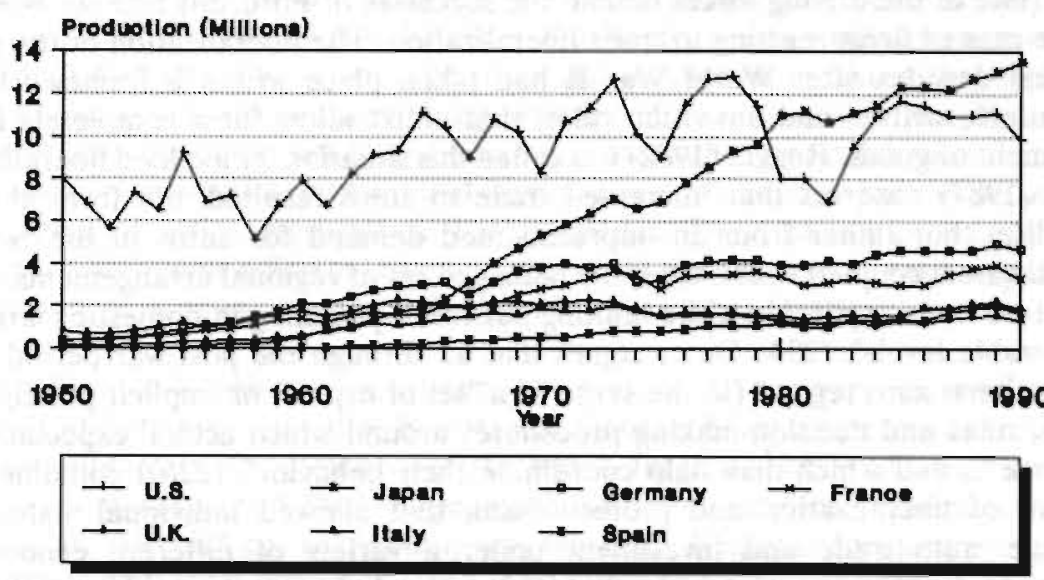

Source: Automotive News

smaller European countries, however, where the Japanese gained market share rapidly, taking over $40 \%$ of the market in countries like Finland and Ireland by the mid 1980s.

\subsection{Car wars}

Any newcomer in an oligopolistic market is bound to pick up market share, once he has overcome the various barriers to entry. Even if the new product is not better than that offered by established firms, some consumers, motivated by curiosity, will try out a new brand and some of them will hang on to it. In this particular case, the new Japanese products often had a better price/performance ratio than competing products. Japanese cars offered features as standard that were only available as expensive 'extra's' on indigenous cars. Quality was good and design was improving rapidly. Wherever they started to sell, the Japanese could increase market share almost without effort. Before they knew it, the traditional car manufacturers were engaged in a fierceful struggle over market shares. The 'car wars' (Business Week) were on.

Two phases can roughly be distinguished in these 'wars'. In the first phase, the Japanese manufacturers were exporting a rapidly growing number of automobiles. This led to major imbalances in international trade and to various forms of protectionist action. In the second phase, the Japanese started to invest in production facilities in the importing countries. This gave the discussion about the 
Japanese production system and its transferability to other countries a very urgent and practical meaning.

The first phase showed in an interesting way how the post war expansion of world trade (one of the driving forces behind the successes of Fordism) had not been a simple case of firms reacting to trade liberalization. The liberalization of trade in the first decades after World War II had taken place within a framework of institutions, written and unwritten rules, that didn't allow for a completely free movement of goods. Ruggie (1982) has called this situation 'embedded liberalism'. Dunn (1987) observes that "increased trade in autos resulted, not from global liberalism, but rather from an unprecedented demand for autos in the North Atlantic area, coupled with a carefully managed set of regional arrangements that permitted trade expansion while limiting outsiders' pouching in domestic markets to tolerable levels". (234) Dunn argues that all through the post-war period the international auto regime (in the sense of a "set of explicit or implicit principles, norms, rules and decision-making procedures around which actors' expectations converge ... and which may help coordinate their behavior". (226)) contained a mixture of liberalization and protectionism, that allowed individual states to 'manage' auto trade and investment under a variety of different economic conditions. For Europe this meant, that trade expanded on a regional level, but the American auto companies had to enter the region through direct investment in local production facilities. "Thus, the European nations' opening to imports was clearly an invitation to European imports." (236) And even then the different national governments took steps to make sure that their auto industries would survive in the new regional competition. "Even in the 1980s, after 25 years of stepped-up trade and lowering of formal trade barriers, each of the big three continental producers still dominates its own domestic market." (237) The Japanese car manufacturers behaved as if they had never heard of all these unwritten rules. Whereas Volkswagen started to assemble cars in North America when it thought that it had achieved the appropriate market share, the Japanese kept on exporting millions of cars. Over the 1970s their market share in the US increased from $4 \%$ to $23 \%$. The result was growing protectionist sentiment in the traditional producer countries. In Europe, old trade restrictions were enforced, giving the Japanese a quota of 3,300 cars for Italy, a maximum of three percent market share in France and almost no import licences for Spain. The British government arranged for a 'voluntary' restraint on the part of the Japanese to approximately $11 \%$ of the UK market. The U.S. government found it difficult to depart from its free trade rhetoric, but under the pressure of worker protests and management complaints also negotiated 'voluntary' restraints with the Japanese Trade Ministry. The Japanese were accused of keeping their own market closed to imports and of engaging in various forms of unfair trade, including dumping.

What made the whole debate difficult for the traditional car manufacturers was that they had also been importing an increasing number of parts and were considering the possibility of 'sourcing' engines and even complete cars in lowwage locations like Mexico or Brazil. In fact, as we have noted in Chapter 4, the first major strategic reaction of the American manufacturers to changing demand patterns was the so-called world car strategy. The idea of a single car to be sold 
on all major markets was tempting, as soon as Americans started to buy smaller cars. The logic of Fordism called for the exploitation of scale economies on a world scale. There would be economies of scale in development and design and in the production of long series of components. A real world car would not only be sold all over the world, but also be produced everywhere, i.e. every part and component in the lowest cost location. Obviously, a strict enforcement of the unwritten rule that cars have to be produced in the region where they are sold would also constrain the purchasing policies of the American and European manufacturers. Anxious not to lose access to potentially large markets and enticed by protectionist legislation, they had invested in production capacities in several developing countries, especially in Latin America. These capacities were usually far below minimum efficient scale and the world car concept seemed to promise a much more economical use of third world (low wage) locations.

First efforts to develop a world car, however, were not very successful. The projects of both Ford (the new Escort) and General Motors (the so-called J-Car) faltered already in the design stage (Dohse \& Jürgens, 1985). Although starting from a common concept, the European and the North American Escorts ended up being quite different and shared only very few parts. Regional development teams, interacting with local regulations and local tastes had received so much room for maneuver that the result looked more like two cars than one. The J-Car (Cavalier, Ascona) was developed in a more integrated fashion. Starting in 1981, it was produced in various locations all over the world. Local versions were not completely identical, but commonality was achieved in such major components as engines, axles, gear boxes, etc.. This offered opportunities for rationalization on a world scale. Profiting from these opportunities, however, turned out to be far from easy. The engine for the J-Car was to be produced in Brazil, but the American consumer preferred a stronger engine so that production plans for Brazil could not be realized. The lessons that the American manufacturers (and their competitors who closely followed these experiments) have drawn from this experience seem to be twofold. First, differences between world regions in taste, regulations, incomes and economic development continue to be so great as to warrant product development, design and marketing on a regional rather than a global scale. Second, commonality at the level of major components is possible, but requires major efforts of coordination in design, production and logistics. The costs of these efforts may be larger than the potential economies of scale. These lessons pointed to a renewal of interest for more modest, regional orientations. Against this background, it became easier for the American champions of free trade to advocate stronger measures against the Japanese export offensive.

The Japanese, it should be understood, were faced with the problem that their home market was relatively small and their own world region full of relatively poor countries that couldn't afford to buy large numbers of passenger cars. The first results of Japanese 'voluntary' restraint were therefore quite understandable, but 
unexpected and not encouraging for the American manufacturers. ${ }^{4}$ Faced by limits expressed in numbers and not in value, the Japanese began to export larger and more expensive cars to the United States, which assured them even higher profits in a market that clearly wanted these cars while exacerbating the U.S. trade deficit. In the longer run, however, protectionism did lead to the logical effect of Japanese investment in production locations in the United States and increasingly also in Europe. ${ }^{5}$ So far, this has not led to a major improvement in the balance of payments between the US and Japan, although the number of cars being imported is decreasing. The American 'Big Three' car manufacturers are now suffering heavy losses in market share to the Japanese 'transplants'. Protectist sentiments are still strong, but now they take the somewhat awkward form of demanding access for American products to the Japanese market.

In Europe, the programme for completion of the internal market has made it necessary to review the protectionist policies of individual member states of the Community. If there is free trade between the member states, import restrictions on Japanese cars for individual countries become impossible. In the summer of 1991, the European Commission has achieved a voluntary restraint agreement with the Japanese, which limits the exports of cars from Japan to the EC to 1.23 million units per year until the year 2000. That is the level achieved already in 1990. From 2000 on, there will be no more restrictions, except for a general import duty (currently $10.5 \%$ ). Furthermore, the Japanese manufacturers will be allowed to increase their share of the EC market to around $16 \%$ by the end of 1999 through the sale of cars that have been manufactured inside the Community. This means that the Japanese can manufacture approximately 1.2 million cars, if demand rises towards 15.1 million as is currently expected. There will be no restrictions on the sale of cars produced inside the Community. ${ }^{6}$ It is widely assumed that the Japanese will further increase their production activities in Europe in the nineties.

Altogether, it seems that the unwritten rule that cars have to be produced by and large in the region where they are sold is still in force. The frontal attack on this

\footnotetext{
4 The first Voluntary Restraint Agreement was reached in 1981. The Japanese manufacurers agreed to limit their exports to 1.76 million cars in the first year. They also consented to limited increases in the following years, leading to a level of 2.3 million in 1985, which has been treated as the maximum since then. Exports fluctuated just under this figure and then started to fall (to 1.7 million in 1990).

s Honda had already announced plans for production in North America before the protectionist pressures became irresistable. Mair (1991, p.64) suggests that both Honda and Nissan have seen transplant operations as a means of overcoming Toyota's predominance on the Japanese market by overtaking it in foreign markets.

"Press reports indicate that there is still substantial disagreement inside the Community on the question if products of Japanese transplants with less than $80 \%$ European content will be counted as local products or as imports.
} 
rule by the Japanese has not succeeded, although growing international trade in components may still be undermining it from another direction. ${ }^{7}$

Once they had overcome their initial reluctance, Japanese car manufacturers expanded their North American operations at an unprecedented speed. Honda was the first to start assembly operations in Marysville (Ohio) in 1982, Nissan followed suit in Smyrna (Tennessee) a year later and Toyota started cautiously by means of a joint venture with General Motors, called New United Motor Manufacturing Inc. (NUMMI), which began operations in a former GM plant in Fremont (California) in 1984. Since then, these pioneers have been followed by Mazda, Mitsubishi (in a joint venture with Chrysler), Suzuki, Subaru and Isuzu. Moreover, Toyota has also started independent assembly operations, while Honda has expanded with additional assembly plants in Ohio and Canada and an engine plant, also in Ohio. In 1990, these so-called transplants (including the joint ventures with GM and Chrysler) produced $21.8 \%$ of all cars manufactured in the US. For two years in a row $(1989,1990)$, the best selling car in the United States has been the Honda Accord. About two thirds of the more than 400,000 Accords sold in 1990 had been built in the U.S. The total capacity of the transplants in North America is expected to rise above 2.7 million by the mid 1990s. Several manufacturers have now also started design and development activities in the U.S.

In Europe, Japanese automotive investments are running at least five years behind the activities in North America. Honda was again the first to appear on the scene, as it agreed to support British Leyland (later called Rover) with the renewal of its product line. This resulted in joint production of a Honda and a Rover model in a British Leyland plant. In the late 1980s an engine plant and an independent assembly operation were added. Meanwhile, Honda has acquired a 20\% ownership in Rover with the rest being owned by British Aerospace. The first to start its own assembly operation in Europe was Nissan. Heavily subsidized by the British government, that wanted to find compensation for the failure of stated-owned British Leyland to maintain its market share, it started assembling cars in Sunderland in 1986. Production has been growing very slowly compared to the American transplants' growth rates. In 1990, Nissan assembled about 75,000 cars in England. It is claimed that local content had reached $80 \%$ by then (Mair 1991, p.72). Toyota will start assembling cars in England in 1992 and will also establish

7 It is sometimes argued that the overseas investment strategies of the Japanese car manufacturers are substantially different from those of the old Fordist multinationais like Ford, General Motors or Volkswagen (Ruigrok et al. 1991; Mair 1991; cf. also Hoffman \& Kaplinsky 1988). The Japanese would combine a global orientation in their operations with intense efforts to turn their foreign manufacturing operations into firmly rooted regional or local actors. This would make them on the one hand less interested in Third World locations, where a manufacturing environment is lacking; on the other hand, it would imply that their subsidiaries in North America and Europe are much more tightly controlled than for instance the European subsidiaries of Ford and GM. To the extent that Japanese car manufacturers depend strongly on a sophisticated supplier infrastructure, it is obvious that they will hesitate to invest in Third World countries (but if they do so, the impact may be larger than that of the investment projects of Western multinationals in the $1960 \mathrm{~s}$ ). It remains to be seen, however, if Japanese subsidiaries in industrialized countries will end up being less independent than the subsidiaries of Ford and GM in Europe. There is no easy solution to the tension between local roots and global control. 
an engine plant there. In Germany, Toyota has a small joint production project with Volkswagen, with the latter assembling about 15,000 Toyota pick-up trucks per year. Mitsubishi has acquired a $33 \%$ share in Volvo Car BV in the Netherlands. Starting 1995, its assembly plant will produce Mitsubishi cars next to the follow-up model of the Volvo 400 series that was developed by Volvo Car in the 1980s.

The Japanese have no doubt proven that they are able to produce their products against acceptable costs in a foreign environment. It has become difficult to maintain that their competitive advantage was based on specifically Japanese circumstances, although this critique will linger on as long as local content is substantially below that of domestic firms. Local content has, however, been rising and given the relatively short time span that the transplants are now operating, they have achieved more than most observers would have predicted (Mair 1991). In the car wars, the battle has clearly shifted now towards a direct confrontation of different management styles, different corporate organizations and different production systems. North American and European manufacturers have no more excuses for performing worse than their competitors, now that these are no longer located in an exotic country, but just across the street.

\subsection{The Japanese production system}

In Chapter 3 we have seen that the institutional forms of the post-war Japanese mode of regulation can be characterized with concepts like cohesion, integration and co-operation. These are not just characteristics of the general political and economic organization of the Japanese economy, but they apply also to the production system that is at the core of the competitive successes of the Japanese automobile industry. Nowadays, the management press is full of articles about Japanese concepts and Japanese systems and it is difficult to realize that only twenty years ago not even Japanese managers were conscious of the fact that a new production system had been developed in their country that was going to revolutionize manufacturing practices all over the world. It was only in the course of the 1970s that the methods of production organization developed at Toyota attracted the attention of other Japanese industries and other car manufacturers. Whereas the majority of Japanese companies incurred considerable losses as a consequence of rising prices following the first oil crisis of 1973, Toyota continued to be very profitable. Toyota quickly became a model to be followed by all others. "From this viewpoint it would not be too much to say that Japanese companies have conquered the depression of oil shock by introducing the Toyota production system partially or totally." (Monden 1983, p.v) Because of this, it is now possible to speak of the Toyota production system as 'the' Japanese production system. In reality, of course, Japanese companies and even car manufacturers vary widely in the extent they have adopted the methods developed at Toyota.

Although it is useful and necessary to differentiate the Japanese approach from the old Fordist methods, it shouldn't be forgotten that it is originally the Japanese configuration of Fordism. Much of what is now considered typically Japanese could 
also be found in Henry Ford's approach of production. The Japanese took Ford's ideas and applied and developed them in accordance with their needs and circumstances. Monden for instance points out that "Toyota's plants are realizing firm-wide integrated single-unit flows of production, which all connect to the assembly line. In this sense the Toyota production system is an extension of the idea behind the Ford system." (Monden 1983, p.69) We don't want to engage here in a scholastic debate about whether or not the Japanese have developed a system that is worthy to be called their own. The point to note is that their system resulted from a long period of intensive experimenting and learning, applying some basic methods and orientations of Taylorism and Fordism in an environment where American levels of mass production were unattainable. Appropriate methods were developed to achieve high levels of productivity and quality for lower numbers and smaller series. By the time that Japanese industry reached 'American' mass production levels, a system of production was in force that was already effective at much smaller production series and consequently offered enormous competitive advantages.

In some crucial respects this Japanese system had come to differ from the various Western elaborations of Fordism. By the beginning of the 1980's first efforts at systematic description of the system were being published outside Japan (Monden 1983, Schonberger 1982). Within a few years, concepts like just-in-time, kanban, quality circles and single setup became familiar phrases in the world of production management. The early descriptions made clear that what was called a system was in fact a set of notions, techniques and organizational devices, that had been developed in answer to various problems and needs over a period of thirty years. In his foreword to Monden's book, Taiichi Ohno, widely recognized as the father of the Toyota production system, emphasizes this point: "(S)ince the Toyota production system has been created from actual practices in the factories of Toyota, it has a strong feature of emphasizing practical effects, and actual practice and implementation over theoretical analysis. As a result, it was our observation that even in Japan it was difficult for the people of outside companies to understand our system; still less was it possible for the foreign people to understand it. (...) Therefore, we are very interested in how Professor Monden has 'theorized' our practice from his academic standpoint and how he has explained it to the foreign people. (...) Although we have a slight doubt whether our Just-intime system could be applied to the foreign countries where the business climates, industrial relations, and many other social systems are different from ours, we firmly believe there is no significant difference among the final purposes of the firms and people working in them." (Monden 1983, p.i-ii)

What is it then that all firms in the world have in common? It is the desire to increase productivity and reduce costs. All accounts of Taiichi Ohno's work at Toyota underline his single-minded search for all kinds of 'waste' in the production process that could be eliminated, be it superfluous motions, unnecessary stocks, indirect work, unnecessary repair, etc. (cf. also Cusumano 1985). "Our approach has been to investigate one by one the causes of various 'unnecessaries' in manufacturing operations and to devise methods for their solution, often by trial and error." (ibid.) 


\section{just-in-time}

One major solution was, as noted above, the extension of Ford's idea of the assembly line to the preceding production departments and the supplier firms. Ford had introduced the idea of a continuous flow of product in final assembly, but the parts and components that were added to the body in the course of the assembly process were produced in large series, exploiting all possible economies of scale. As a consequence, the Fordist assembly lines were surrounded by large stockpiles of parts. In his critical search for 'unnecessaries' Taiichi Ohno identified these inventories as 'waste'. Not only did the inventories tie up considerable sums of capital, but they also occupied space and even more important: they encouraged a lax attitude towards quality. Workers, who had to produce large series of the same product, became bored and negligent of product quality. Assembly workers on the other hand, who found defective parts, simply took another one from inventory. There was no reason to feed back information on the defect to the relevant production department: the part had probably been produced weeks or months earlier and meanwhile other parts were being produced. It was simply accepted that part of a series would be defective. Ohno set out to eliminate this waste. The basic idea was that parts and components should only be produced in the quantity needed for current production. Ideally, there would be a single piece flow of parts and components in the direction of the assembly line, where they would arrive just in time to be used. This was of course an old idea, the dream in fact of every production engineer, but Ohno went farther than anyone else in systematically eliminating obstacles on the road to single piece flow production. ${ }^{8}$ Knowing about the irregularities of production, he didn't try to develop a master schedule that would give every department precise instructions on quantity, timing and sequence of the items it had to produce. Instead of 'pushing' all departments at the same time, trying to have them behave as a single machine, final assembly was given the task of 'pulling' the parts and components it needed from the various departments. The means for doing so were simple order forms, so-called kanbans, that were connected to the containers and racks with the various parts used in assembly. These containers held small lots of parts, enough for maybe 5 vehicles. An empty container was to be returned to the relevant production department and exchanged for a full one; the attached kanban was a signal that that particular part had to be produced again. Without kanbans, no production was allowed. If production was interrupted in final assembly, no kanbans were forthcoming in the other departments and the whole plant would fall still. Changes in final demand translated automatically to changing demands on the supplying departments. Of course, the latter had to know roughly what kind of demand they could expect in order to prepare for adequate personnel, machinery and materials, that had to be ordered from their suppliers. Such information was given in the form of monthly

8 "There was an heroic era of stock reduction from 1955 to 1969 when the Japanese manufacturers took out three weeks of stocks and reduced their sales cover from 9.2 to 6.2 weeks. But, in the past 20 years, the Japanese have not managed any steady improvement in their turnover stock ratios.(...) (A) leading edge enterprise like Toyota, which runs on nine days stocks, has effectively reached the end of the road." (Williams et al. 1989, p.98) Continuous improvement in these 20 years may, however, have contributed to keeping stocks at the same level while introducing a larger varicty of often more complicated products. 
production planning. Normally, daily production would be a commensurate share of the production planned for that month, but actual daily production orders could differ substantially (in size and mix) from those plans. The only one to be informed about such deviations, however, was final assembly. All other departments were informed 'just in time' through the kanbans they were receiving. In this way deviations of up to $10 \%$ could be dealt with without problems.

Of course, many preconditions had to be fulfilled for a system like that to run smoothly: technical, organizational and social. In order to avoid a sudden surge or fall in demand for any part, special care was taken to smoothen out the variety in final assembly as much as possible, i.e. a steady mix of vehicles would come off the line. Moreover, the lead times for the production of all parts had to be shortened tremendously. Producing small lots of components ran counter to the logic of mass production, where economies of scale would be reaped by running expensive (often dedicated) machinery for long periods without interruption. Small lots implied frequent interruptions of production for the exchange of tools and dies. This was absolutely uneconomical as long as setup times ran into hours or even days. By various technical and organizational devices, however, setup times at Toyota were reduced to just a couple of minutes (a setup of one digit, i.e. less than ten minutes was designated as a 'single setup'), which greatly reduced economical lot sizes.

High levels of machine utilization, moreover, were not necessarily a good thing in the eyes of Taiichi Ohno. ${ }^{9}$ Given the fact that different machines have different capacities, high utilization rates will only lead to inventories. Instead of having a machine running for three weeks and then standing idle for one week, Ohno preferred the machine to run for three minutes and then stop one. This resulted in a completely non-Fordist concept of work organization in the machining shops. The Fordist approach was to have specialized machines in specialized (functional) departments with specialized workers. Batches of workpieces were moved from one specialized department to the next for different operations to be performed. Toyota brought together all machines that were necessary to produce a certain part and placed them in a U-shaped line. Each machine was provided with a device that made it turn off automatically after completing its operation on one part. That made it possible to differentiate more clearly between the operating time of the machine and the operating time of the worker. A worker could walk from one machine to the next along the U-shaped line, starting an operation on the first machine, carrying the workpiece that he had just taken off that machine to the second operation, etc., so that after completing one round, one unit would be finished. In that way, one worker could operate a large number of machines, maybe as many as 15 , simultaneously. With one worker, the cycle time for producing one unit is the time the worker needs to make one round. It is possible, however, to change the cycle time by changing the number of workers. Figure 9.4

${ }^{9}$ As Williams et al. (1989) correctly observe, this implies that the elimination of one kind of waste (stocks) was preferred above the elimination of another (idle machinery). "In a Japanese factory with a pull through production system and zero stocks, all the machines must run at the pace of the slowest machine on the line: stocks are kept low by shutting down the faster machines or running them on extended cycle times." (p.101) 


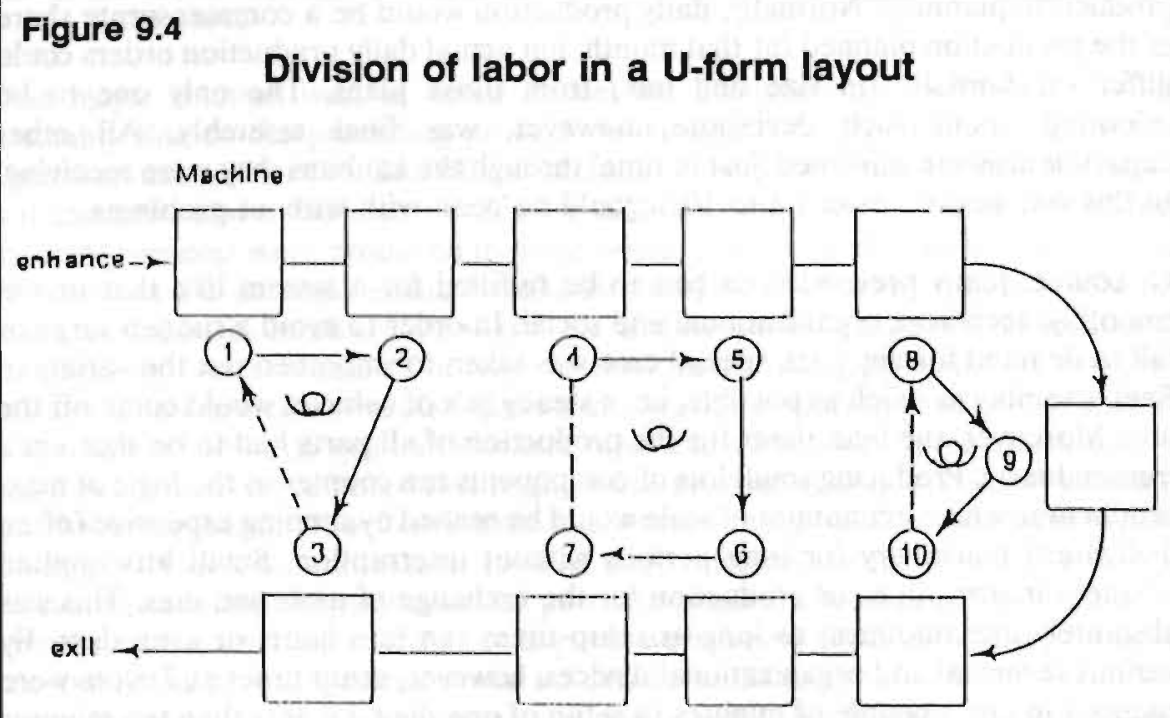

Source: Monden, 1983

shows how three workers can be operating one U-shaped line. The cycle time is correspondingly shorter (but of course cannot be less than the time any of the machines needs to carry out its operation). Note, that the three workers do not simply operate a number of consecutive machines on the line. Their division of labour is such that walking distance is minimized. Even more flexibility is achieved by combining several of these U-shaped lines into one integrated whole. This is illustrated in figure 9.5. Figure 9.5.a shows the layout of the production lines for six different parts. Figure 9.5.b shows how eight workers operate all these machines with a cycle time of one minute per unit (i.e. one unit of each product per minute). Figure 9.5.c shows how lower demand is translated in a longer cycle time and consequently in a lower number of workers with a longer walking route. Contrary to Fordist arrangements, workers in this environment had to be able to operate many different machines, i.e. they had to be 'multi-skilled'. That doesn't necessarily mean, that they had to be highly skilled. Learning to operate each machine might be a matter of hours. ${ }^{10}$ Nevertheless, more skills were required than in the traditional Fordist setup.

10 "For example, the load on a machine ordinarily is set at about $90 \%$ of its full capacity and each worker, operating as a multi-function worker, might handle as many as ten machines. When demand increases, temporary workers will be hired and each worker will handle less than ten machines, thereby enabling $100 \%$ utilization of machine capacity. It is, however, necessary to have machines that even a newly hired, unskilled laborer will be able to become fully proficient on within three days." (Monden 1983, p.58) 
Another important difference flowing from the lay-out and the presence of multiskilled workers is what Toyota calls the mutual relief movement. The point where two workers meet in a production process is treated as a zone of potential overlap. If a worker wants to pick up a workpiece and finds that it hasn't been taken off the preceding machine, he will do that for his delayed fellow worker so that the latter can catch up and work can go on. In this way, a flexible line balancing mechanism is introduced that takes care of deviations from the precisely measured standard times for each operation that went into the planning of the work organization. "Human friendships may be cultivated through such teamwork under the mutual relief system", writes Monden (1982, p.73). Whether it should be called friendship or not is open to debate, but it is well known that Japanese automobile workers are under considerable pressure to consider the interests of their 'team' higher than their individual interests. They are expected to spend a lot of their free time with their colleagues. Their families and even their health are of secondary importance. "The Japanese employment system, wage system, the system of transferring workers among various departments, and the on the job training system for cultivating versatile workers are all based on the principal Japanese value of group consciousness. For the purpose of attaining total system effectiveness in a society which had no additional frontiers, excessive individualism had to be restrained." (Monden 1982, p.116) In practice, this meant that Toyota workers were pressurized into accepting the considerable flexibility that was required from them. In the final analysis, the ease with which the just-in-time system could accomodate considerable deviations from original production planning was based not just on technical devices, original layouts and innovative work organization, but also on the willingness of workers to work overtime if necessary and to accept (temporary) speedups of production.

A further deviation from the Fordist model, flowing logically from the workings of the just-in-time system, is that responsibility for quality is given to production. In the Fordist system it had become the rule that separate inspectors and separate quality control departments were responsible for product quality. In the eyes of Taiichi Ohno, these people didn't add any value to the product, so they should wherever possible be eliminated. Workers should be encouraged to take responsibility for the quality of their own work and in the case of one piece flow production that is almost self-evident. Every time that a worker passes on a defective part, it will usually be noticed already at the next station and production will fall still, because there are no other parts available. In other words, just-intime stands for a quick feedback on quality defects that can then be corrected immediately. If workers are responsible for quality, they must have the means to assure that no incomplete or defective component leaves their workplace. A lot of attention was paid at Toyota to the development of techniques that would allow for the detection of defects or abnormalities and a subsequent stoppage of the line or machine. Some of these were technical devices of the type that also stopped a machine automatically after finishing a job. Others were simple statistical methods that allowed workers to check quality through sampling. For workers on a moving assembly line, quality control is difficult because they have only a given cycle time and then the workpiece is leaving their work area again. In traditional Fordist assembly lines, this leads to defective parts being consciously built into the car (to 
Flgure 9.5

\section{Job Rotation in Japan}

A

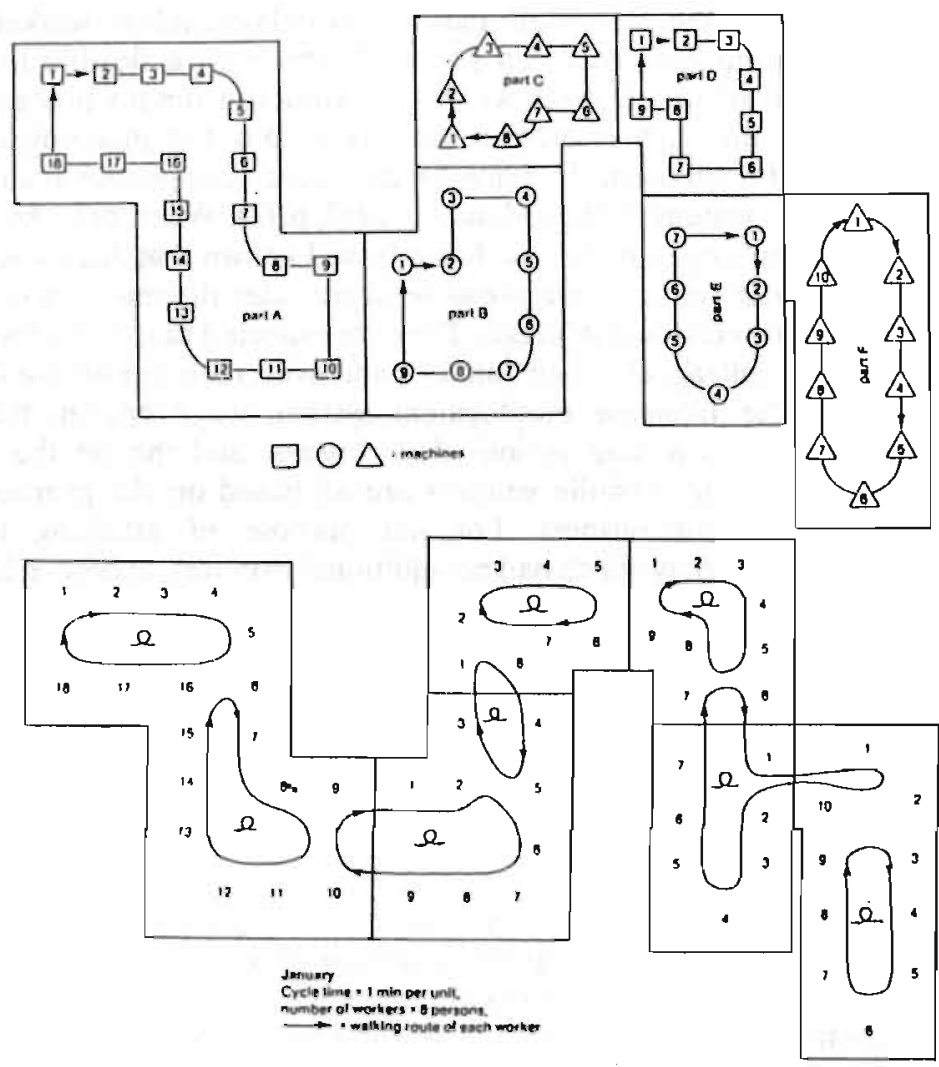

B

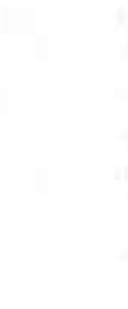


be removed again in later repair areas) or in incomplete cars rolling off the line. Western car manufacturers who visited Japan in the 1970's and 1980's were dismayed to find that Toyota had given its assembly line workers the possibility for stopping the entire line. In their countries, they argued, workers would stop the line all the time and production would come to a complete standstill. At Toyota, on the contrary, workers did all they could to avoid stopping the line. Instead of signalling that they couldn't finish their task on time, they tried to finish their task outside the area of their work station, 'drifting' along the line. In the border areas of work stations management therefore had installed mats, that would stop production if stepped upon (like the type that opens doors in supermarkets), so that imbalances and quality problems would become visible.

Added to the individual responsibility for product quality was the collective practice of continuous improvement activities. Henry Ford, of course, had always been searching for improved machinery that would enable him to produce quicker and cheaper. This search for advances in mechanization and automation, however, was combined in the Fordist system with the Taylorist notion of the one best way to carry out a specific operation. In the Japanese system there is no such notion of optimality. There is always room for further improvement, not just through new or improved machinery but also through a further refinement of manual motions, a new lay-out or new economies in the use of materials. Such improvements are not imposed one-sidedly on production by some engineering department, but they are developed in meetings of small groups of workers called quality control circles. All employees must participate in some quality circle, which are led by a supervisor. A circle selects a problem and develops a solution that is submitted for approval and advice. Technical support may be forthcoming from engineering staff. A well-developed structure of evaluation committees ensures that proposals are dealt with quickly and seriously. Apart from their participation in quality circles employees are encouraged to develop and submit improvement ideas on an individual basis (kaizen). In this way a process of continuous improvement is kept in motion, that makes optimal use of the practical insights and ingenuity of the workforce. Workers are not only engaged in the rationalization of their own work process, but they are actually said to be motivated by management's recognition of their capabilities. "(A)llowing the worker to take it easy or giving him high wages does not necessarily provide him an opportunity to realize his worth. On the contrary, that end can be served better by providing the worker with a sense that his work is worthwhile and allowing him to work with his superior and his comrades to solve the problems they encounter." (Monden 1982, p.131)

Of course, most of these continuous improvement activities on the shop floor are concerned with incremental improvements. They point management to faulty details and inefficiencies that are bothering workers and, if solved, may improve worker morale considerably. It would be wrong, however, to see 'continuous improvement' mainly as an instrument to improve morale. Incremental improvements have come to play a central role in the Japanese production system. In the traditional Fordist approach, production was responsible for production, design for the product and engineering for productivity. The industrial engineers were practically the only ones concerned with incremental improvements, 
continuously struggling with the workers over methods and standards. The 'real' improvements in productivity and quality, however, were associated with the introduction of new products and production equipment. ${ }^{11}$ The Japanese have recognized that a large number of small steps are just as valuable as a big jump and often much more manageable. This has led to novel forms of interaction between production, design and engineering. The introduction of new products is not the occasion for another big jump in productivity, but almost the opposite: a chance for consolidation of the small steps that were made in the lifetime of the previous model. Design is from the beginning interacting with production concerning the manufacturability of a new product.

Much earlier than the Western firms did the Japanese car manufacturers realize that quality (producing what the consumer wants at lowest possible costs) cannot be the responsibility of a specialized department, but must be the concern of every person and every department in the firm. Special efforts were undertaken to ensure that the activities of the departments in this respect were coordinated by formally constituted meetings of top-level managers. These meetings could make policy decisions that were binding on individual departments, so that a unified company-wide quality control and cost management could be achieved. Again, what we find here at the level of corporate organization is the same feature that we also found in the organization of production and in the social institutions of post-war Japan (cf. Chapter 3): without neglecting the benefits of a division of labour, there is constant attention for the need to connect what is separated, for co-operation and cohesion, for integral policies and strategic orientations as a necessary corrective on the short-sightedness and narrow-mindedness that come with specialization and the Fordist divisions of labour.

\subsection{The industry context}

It is not the purpose of this book to provide an extensive description of the Japanese production system. The pages above should suffice. They show that it is on the one hand a system based on sound industrial engineering, a further development of the best ideas of Taylor and Ford, resulting in the now famous just-in-time system. On the other hand, it has become clear that the engineers in this system are co-operating more closely with production workers and that there is generally less emphasis on division of labor than in Fordist systems. We have indicated already in Chapter 8 that the just-in-time production system as a set of technical and organizational devices is predicated upon a larger set of organizational arrangements and social institutions. Some of these are more or less national institutions that have been dealt with in Chapter 3 , especially referring to the functioning of the Japanese labor market. In the following, we will look briefly

11 Traditional Fordist thinking is focused on optimizing a production line when it is introduced. Once production has started up, textbook economic reasoning says, that with given equipment economically feasible improvements will diminish beyond some point in time (the law of diminishing returns). The Fordist assumption seems to be that this point comes very quickly. 
at some arrangement that are more specific to the automobile industry: especially the relations with supplier firms, and the organization of industrial relations.

\section{supplier relations}

The logic of the just-in-time system demands that it is extended to the supplier firms of the car manufacturers. Stockpiles of parts and components are just as wasteful if they come from suppliers as if they come from internal production departments. Moreover, they cause the same problems in the field of quality. Already in the early 1960 s, therefore, Toyota's just-in-time system was extended to its suppliers (Monden 1982, p.35). This was the more necessary as Toyota had traditionally produced only a small part of the car in-house and relied heavily on a large number of suppliers. It was relatively easy to introduce a just-in-time system, based on the exchange of similar kanbans as were used inside the firm, because Toyota's suppliers typically were located in the immediate vicinity of its main assembly plants. Many of these suppliers, moreover, were tied to Toyota and to each other by (partial) ownership (some, e.g. Nippondenso, had been part of Toyota before gaining an independent status), by the exchange of personnel and knowledge, by a tradition of co-operation and long term contracts. These direct suppliers naturally have their own suppliers, who in turn also have suppliers, etc. In the Japanese car industry these hierarchies of suppliers have been more pronounced than in other countries because of the lower level of vertical integration of the Japanese manufacturers. Japanese car manufacturers did not assemble major components themselves, but left this job to 'first tier' systems suppliers. In the course of time, the latter developed into specialized manufacturers of major components with considerable capacity for research and development. Although first tier suppliers may have privileged relations and exclusive contracts with one assembler, the supplier hierarchies of the various Japanese car manufacturers are connected to each other, so that the industry should not be pictured as a collection of isolated pyramids, but rather as a 'mountain range' with a great deal of overlap at the lower levels (Nishiguchi 1987).

In principle, introducing just-in-time relations with supplier firms was not different from doing the same in the relations between production departments of Toyota. Toyota was to give monthly indications of the quantities of parts it was intending to buy, but delivery would depend on the presentation of kanbans. Deliveries could be daily or even more frequently, sometimes even in the same sequence as products were rolling off the line (e.g. transmissions or seats), and suppliers were expected to have the capacity to adjust to substantial deviations from the monthly planning figures. Problems could arise, of course, from the fact that a supplier might be having other customers besides Toyota. If all customers are requiring delivery flexibility, the supplier may be forced to have considerable surplus capacity (just in case demand from several customers peaks at the same time) or large inventories of finished or semi-finished products. To avoid such unwanted developments, special care was taken by Toyota to ensure a smoothened-out demand pattern. Nevertheless, suppliers, and especially those two or three tiers away from Toyota, were experiencing a lot of pressure and had to put up with considerable losses when the system was being introduced. Questions were asked 
in the Japanese House of Representatives about "this practice of bullying the subcontractors" (Monden 1982, p.46). The 'Fair Trade Commission' and the agency for Small and Medium Enterprises of the Japanese government looked into the matter and developed guidelines in accordance with existing laws on competition policy and on subcontracting. As more and more manufacturers adopted the justin-time system, the problems seem to have diminished as far as threatening the survival of the smaller firms is concerned. Complaints that it led to an intensification of production in the smaller firms have been raised frequently, but to the extent that this is true the system has not met with effective resistance from workers. Monden aptly observes that "unless there is opposition from a labor union, this system can be applied to any company in any country" (1982, p.51).

In their efforts to learn from the Japanese, many Western car manufacturers are currently reducing their levels of vertical integration and turning to independent suppliers for all kinds of parts and components (cf. Chapter 7). The reasons why Toyota and other Japanese car manufacturers have chosen to have a comparatively low degree of vertical integration are clearly of interest, but not easy to pinpoint. Obviously, make-or-buy decisions are led by cost considerations, but why were cost structures in Japan so different, that the Japanese departed from the Fordist model of high vertical integration? The analysis of Odaka et al. (1988) suggests that the large wage differential between large (assembler) firms and small (supplier) firms may have some explanatory value. At least in the 1950s, this wage differential between large and small firms in the automotive industry was much larger in Japan than in the UK or the US. The same was true, however, for the differences in productivity, so that this explanation is not as strong as it seems at first sight. An important factor is no doubt the political environment in which the industry grew up. The history of the parts suppliers is closely intertwined with government initiatives to strengthen the engineering and automotive industries of Japan dating back to the 1930s. Parts suppliers didn't have to fear competition from outside the country because the government strongly protected the domestic industry. In the pre-war years, buyers of motor vehicles in Japan fell mainly into two categories: extremely rich individuals on the one hand and the Armed Forces on the other. Both categories were less interested in costs than in quality and performance. This encouraged the rise of specialized parts suppliers. The small size of the market did make it necessary to reduce the number of suppliers in order to achieve some economies of scale. This resulted in the adoption of the so-called two-supplier principle. After careful selection two suppliers for each major part were given privileged status by the assembler. These two could count on orders as well as financial and technical support from their long-term partner, but would be constantly forced to compete with each other. By the end of the 1930 s these firsttier suppliers began to group themselves around the three authorized vehicle manufacturers, encouraged by the latter as well as by government. Toyota took the initiative of organizing its unaffiliated suppliers into a suppliers' association (in 1939). Other manufacturers followed this example in the course of the 1950s. The suppliers' associations have, among other things, been a vehicle for providing technical assistance to the suppliers in order to improve their operations. It is unusual for one supplier to belong to more than one association, although he may be supplying more than one assembler. 
Government support for the automotive industry after the war basically reinforced existing industrial structures. Intense competition in a quickly growing and highly protected market forced the assembler firms to expand and modernize their production capacity as quickly as possible. Both the wage differential mentioned and the presence of well organized groups of preferred suppliers made assistance to these suppliers the obvious (cheapest and low-risk) choice for the car assembler above any effort to expand in-house production. In view of the relatively small series produced in the $1950 \mathrm{~s}$, moreover, it would have been difficult to realize economies of scale with in-house parts production. The extended conflicts with unionized workers in the first post war decade may also have led managements to avoid wherever possible the grouping of large numbers of workers under one roof. From this perspective, the low level of vertical integration in the Japanese automobile industry is not so much the result of consistent strategic action, but rather the outcome of a historical growth process. A low level of vertical integration by itself does not offer competitive advantage. Just-in-time procedures can be just as well installed inside one plant or one enterprise. Various circumstances may make it cost-effective to engage in outsourcing instead of inhouse production, e.g. wage differentials, readily available production capacity, technological knowledge, and shortage of capital. Apparently such circumstances prevailed in Japan throughout the buildup of the car industry. It is interesting to note that the level of vertical integration has been increasing in Japan in recent years (De Banville \& Chanaron 1991, p.26/27). ${ }^{12}$

\section{industrial relations}

The just-in-time system was aimed at eliminating all kinds of waste, not just inventories but also superfluous workers, by the elimination of idle time and unnecessary motions. What was unnecessary and superfluous was established by traditional industrial engineering techniques (time and motion studies) as well as by trial and error: by speeding up production without adding workers or by withdrawing workers and keeping up line speed. Only operations that added value to a product could be tolerated. Obviously, walking and waiting do not add value and had to be eliminated. Workers were confronted with the message that the operating time of a machine was not to be considered as their working time. That was the idea behind the U-shaped lines of machines along which they had to walk or preferably run. The result was a system that put the individual worker under enormous pressure. ${ }^{13}$ In the course of the 1970 s, several publications accused the

\footnotetext{
${ }^{12}$ In view of the widespread practice of intricate relationships of partial ownership between the firms that make up a supplier network for a car manufacturer, one can also question the validity of the statement that vertical integration is low.

${ }^{13}$ Monden denies that the just-in-time system represents a form of intensification. What happens in his view is simply the elimination of wasteful actions and their replacement by actions that add value. In this way the total standard time for operations can be reduced and therefore the number of workers. "Unless this point is fully understood, the Toyota production system is hard to apply, especially in an environment where the labor union is strong." (Monden 1982, p.125) Labor unions would want the workers to share in the gains arising from higher productivity, but apart from that there is no reason why they would resist such a neutral
} 
system of having such a pace that it caused major accidents and led to an unusually high number of suicides. Satoshi Kamata, a journalist, went to work at Toyota as a seasonal worker in 1972 and put down his exhausting experiences in a book that appeared under the title 'The Automobile Factory of Despair' (Kamata 1986). ${ }^{14}$ Proud and motivated Toyota workers are not to be found in this book; only lonely and desparate people who never get enough sleep. In 1983 Cusumano interviewed Taiichi Ohno about these accusations. "(T)he inventor of Toyota's production techniques acknowledged that shop managers were slow to add workers to the lines when production orders rose; instead, they usually shortened cycle times and increased the exchange rate of kanban. Workers hated this and the technique of operating several machines at once, recalled Ohno, who admitted that he never felt the need to try operating several machines simultaneously to see how easy or hard it was." (Cusumano 1985, p.306)

Why then didn't the Japanese workers resist the new production system? The truth is that they did, but they lost. Two major reasons can be given for the inability of Japanese workers to resist the intensification of work in the first post-war decades. The first is the development of an employment system that encouraged and rewarded loyalty on the part of the employees (cf. Chapter 3 ). The second is the rise of company unions and the destruction of industrial unionism in the early 1950s. The two obviously are related. Characteristic for these arrangements is that they accentuate major dividing lines in the Japanese automotive workforce: between workers with a lifetime employment guarantee and temporary workers; between employees of supplier firms and employees of the assemblers and between the employees of different assemblers. Divided along these lines, workers couldn't resist the new production system and had to learn to live with it. Moreover, as we have noted, many intensifications were not imposed unilaterally on the workers but elicited from themselves by means of quality circles and other techniques to induce 'continuous improvement'. The presence of a relatively high number of persons with supervisory powers in production may also have contributed to an environment in which opposition was difficult to organize and all 'waste' could be eliminated (cf. Jürgens \& Strömel 1987). In fact, it should be underlined that the emphasis on mutual support, teamwork and group activities is combined with a highly individualized evaluation and payment system.

redefinition of jobs in an environment with life-time employment guarantees - unless, of course, the redefinition is not neutral but represents a clear intensification of work. Transferring superfluous workers to other departments may not be enjoyed by the workers concerned (although it is better than being dismissed). It also runs counter to the strategy of encouraging a 'team spirit'. Monden insists that the hest workers should always be removed first. "If a dull or unskilled worker is moved, he may resist, his morale may suffer, and he may never develop into a skilled worker. An oustanding worker, by contrast, is usually more willing to be moved since he has more sclf-confidence and may welcome the opportunity to learn other jobs in the factory." (Monden 1982, p.122)

14 This is the translation of the Japanese title as given by Cusumano (1985, p.305). The book later appeared in english under the title 'Japan in the passing lane'. 
The development of unionism in the Japanese automobile industry deserves some more attention, because it shows important differences with developments elsewhere. It is difficult to estimate the importance of the weakness of Japanese unions for the success of Toyota and other car manufacturers, compared to the impact of undoubtedly innovative and effective management techniques. According to Cusumano, Taiichi Ohno considered his success in controlling the union the most important factor contributing to Toyota's predominance over domestic and foreign competitors. Ohno had served as a union official for one year before joining the ranks of management in 1948. In his new position as head of a machine shop he became a central figure in a five year plan starting that same year, aimed at increasing productivity and reducing inventories. He knew all the union leaders and could convince them not to reject his proposals outright. The opening that was thus created turned out to be enough. By the end of 1955 he had overcome most of the opposition to his techniques (Monden 1983, p.307). In those seven years between 1948 and 1955, a period of intense social struggles, the foundations were laid for the Japanese production system.

Before the war, unionism had not been very important in Japan. After 1945, however, unions increased rapidly in strength, supported by the democratization efforts of the occupying forces. Some of these were company unions, but there was also a rapid growth in the number of industrial unions. In 1947 an industrial union was started for the automobile workers, which followed the example of the United Automobile Workers (UAW) of the US and organized only blue-collar workers. In 1954 the union was dissolved after a major strike movement starting in 1953 at the three largest car manufacturers of those days, Toyota, Nissan and Isuzu. While agreements were reached after several months of action at Toyota and Isuzu, Nissan management refused to give in (strengthened by secret promises of Toyota and Isuzu that they would not try to take market share away from Nissan). Violence increased as the union tried to force doubters into the strike and management hired thugs to beat up union organizers. Then, after nine weeks of strike, Nissan management locked out the union and at the same time a group of white-collar workers started a new union, open to all employees of Nissan. Whoever became a member of the new union was allowed to come to work and immediately received pay, even though at that time production was impossible. This was just after the Korean War, the highpoint of the Cold War, and the old union was accused of being communist and above all un-Japanese. Members of the old union tried to force the factory gates. Violence erupted and the union president was arrested and jailed. The new union grew in membership every day. Two months after the new union had been launched, the old union admitted its defeat. Its leadership was fired immediately. Over the next two years nearly two thousand workers were fired at Nissan and basic wages for workers were cut $16 \%$ in the first year. "From now on, each company would have its own union, which would be totally loyal to its parent company and dependent upon the marketplace success of the company for its own success. Management had won; it could not go back to the pre-MacArthur days, when there were no unions at all, but it had defined labor on its own terms, incorporated labor into the company itself, and ended any possibility of labor as an adversarial force within." (Halberstam 1986, p.181) 
Taking the first oil crisis as turning point (but not necessarily as a cause), we can see the past two decades as a period of active search for new rules and institutions by all actors in the automobile industry. The new rules have to accomodate the new requirements arising out of the limits reached by the Fordist system on the one hand and the opportunities provided by technological, social and political developments on the other. Governments have enacted a whole new set of rules concerning safety, fuel efficiency and pollution. Japanese export strategies, the rise of newly-industrializing countries and the 'world-car' strategies of the American automobile multinationals set out to change the international division of labour, but change remained limited in the face of real and potential protectionist action. The old 'rule' that cars have to be produced in the region where they are sold, seems to find renewed support. The supply of new technologies interacted with the criticism of the quality of work on the assembly line and gave rise to new job profiles, new training programs and new forms of work organization. These require that industrial relations are played by rules of trust and co-operation instead of antagonism and conflict. Technologies providing economies of scale have lost some of their relevance with the rise of technologies that provided economies of scope, i.e. flexibility of the production system and variability of the product at affordable costs. New routines of product renewal and variation are being established.

During this whole period of search, the Japanese car manufacturers seemed to have the solutions even before the others had defined the problem. When the search started they were already ahead of the others, because they had departed earlier from some Fordist patterns in order to suit the limits and requirements of their own market. Over the past decades they have used whatever advantages they had to improve and elaborate their system. As long as the Japanese were only producing in Japan, it could still be argued that the high competitiveness of the Japanese manufacturers was based on national and/or sectoral institutions that were deeply rooted in Japanese culture and often unacceptable to Western workers and managers alike. It would therefore be impossible to reproduce the Japanese successes elsewhere. It could even be argued that the cost advantages of the Japanese manufacturers, to the extent that they were related to the suppression of unionism, gross exploitation of workers and bad working conditions, should be taxed away through import duties. These duties would protect the humane standards of the American and European industries. Such arguments, supported especially by parts of the UAW, were difficult to sustain, when facts came on the table (Jürgens et al. 1989). Various investigations carried out in the early 1980s, some even paid for by the UAW, showed that the cost advantage of the Japanese manufacturers was based to a large extent on such things as a higher degree of automation, better product design, higher utilization of machinery, better quality control, better industrial engineering and lower absenteeism. According to Abernathy et al. (1983, p.84ff) higher speed of work accounted only for $4 \%$ of the difference in productivity between Japanese and American manufacturers. It became clear that the Japanese had developed a superior production system, overcoming at least some of the limitations that had become visible in the 
traditional Fordist system. Its 'transplantation' to North America an Europe was the logical next step. Although we have to take into account that the transplants are usually starting under extremely good preconditions (a new workforce, a new plant), their performance has been quite impressive.

This is a major theme of the second MIT study on the automobile industry (Womack et al. 1990; the first study was Altshuler 1984). According to Womack and his co-authors, Japanese car manufacturers compared to their still largely Fordist competitors now need less of every input to produce the same or better products. This is why they call the Japanese Production System 'lean production'. In the course of the 1980s Taiichi Ohno's original system has been further improved and applied to all major functions of the enterprise. The competitiveness of the Japanese is not just located in the assembly plant, but also in engineering, design, product innovation and marketing. It has become a systemic advantage. Womack et al. argue that 'lean production' is bound to replace the Fordist system all over the world. Lean production, in their view, is a new stage in the history of car manufacturing and indeed of all manufacturing. After craft production as practiced in the workshop of Gottlieb Daimler in the late 19th century and mass production as developed by Ford in the early decades of the 20th century, lean production will carry the industry into the 21 st century.

In other words, for Womack et al. the search is over. The new rules have been found. The only problems they see, are problems of diffusion. These problems arise mainly from the resistance of both managements and workers, who have vested interests in old-style Fordist mass production, and from outdated thinking that hasn't yet grasped the full meaning of the lean production system. Obviously, if lean production has twice the productivity of Fordist mass production, thousands of automotive jobs in North America and Western Europe are threatened. Womack et al. agree that a serious effort to convert to lean production will create massive employment problems, which may require government action. In the long run, however, the price of not converting will be far more costly than any program for training and re-deployment. It would mean either the complete and swift destruction of the North American and European car industries by the Japanese competition or, because this would be politically unacceptable, the permanent protection of an industry with standards of productivity and quality far below the world's best practice. In the long run, the last course of action would be untenable, as the recent past has already shown. Womack et al. underline that, compared to earlier visions of the future of the industry, lean production at least envisions a continuation of automobile production in the advanced industrialized countries. As long as the industry was the preserve of routinized, unskilled labour, producing mature products with known technology, relocation to the less developed regions of the world seemed imminent. Lean production on the contrary aims at the continuous improvement of products and processes, it offers challenging work for multi-skilled workers and is based on the close interaction between customers, manufacturers and suppliers. Lean production therefore is much more inclined to build up stable local or regional networks of production and to preserve the automotive industry in the industrialized countries. 
Womack at al. have chosen to emphasize the transferability of the Japanese Production System to other countries. Their study is strong on the facts of Japanese superiority. It is not very detailed in the description of the methods that the Japanese use to achieve this superiority, but this lack of detail is compensated for by their emphasis on the overall picture: the coherence of various aspects of the 'lean enterprise'. The study is lacking in its analysis of the problems of implementation and diffusion. Paradoxically, this is the result of the emphasis on transferability. Lean production is largely presented at the level of the enterprise, as a management approach, and its adoption a responsibility of management. Consequently, its roots in post-war Japanese history and its links to the economic and social institutions of modern Japan are under-emphasized. The importance of the 'keiretsu' and the Japanese financial system as sources of cheap finance throughout the 1980s for instance are acknowledged, but there is no discussion of the difficulties for organizing a similar environment in other countries. Womack et al. want to emphasize that cheap finance will not help the traditional manufacturers, if they do not adopt lean production methods. This may be true, but the problem remains that they would still be disadvantaged after the adoption of lean production, compared to their Japanese competitors, as long as the financial institutions of the Western countries prevent similar methods of organizing cheap finance.

It cannot be denied that the Japanese model ('lean production', Toyotism) is serving as an important guidepost in the search for a post-Fordist order. Much of that model, however, is defined only at the production or enterprise level. The economic and social institutions that shape the context of this production system in Japan are often found less attractive or politically unacceptable in other countries. Moreover, the development of lean production in Japan was related to a strong and long-lasting expansion of exports. It is unclear if and how it will survive in an environment where exports have to be replaced by domestic consumption. Womack et al. (1990, p.278) argue that at its present stage, lean production can be compared to Fordism in the early 1920s. This may very well be true, but the implication then is that we still have a long stretch of crisis and search ahead of us. Our analysis of Fordism (Chapter 3) points out that Fordism was rapidly spreading in the 1920 s at the level of the enterprise. Social and economic arrangements were lacking, however, to ensure that mass production was met by mass consumer demand. It took the depression of the 1930s and a World War to destroy some of the old institutions and pave the way for new solutions. Womack et al. seem to argue that crisis and war could have been prevented if Fordist mass production had been allowed to progress more quickly (1990, p.234). The point is, that mass production could not progress in the old environment. That was not just the case in Europe: even in the country where Fordism was invented, economic crisis and major institutional innovations were necessary to make it work as a generalized system of production. The implication is that the diffusion of lean production will require the creation of a new set of institutions at the national level (even in Japan) and at the global level: a new mode of regulation for capitalist accumulation in the 21 st century. 
In Chapter 8 we have argued that differences in national institutional arrangements will lead to various adaptations of the Japanese model in each country. National versions of lean production will develop, just as there were national versions of craft production and Fordist mass production. On the other hand, we have also seen (in Chapters 7 and 8) that efforts to implement the lean production system may lead to pressure on existing organizational forms and institutional arrangements. There will no doubt be pressure to adopt some of the institutional forms that have supported the development of the Japanese production system. There will also be pressure, however, on the Japanese to adapt some of their institutions to the standards of other countries. This is visible already today, for instance in the field of working hours, where the Japanese are under strong international pressure to lower the number of hours worked per year by the average worker. Global arrangements concerning trade and trade restrictions, financial markets, subsidies and the recognition of patents, to name but a few, will have to follow. The new rules for the industry are beginning to materialize, but the shape of its future environment is still unclear. 


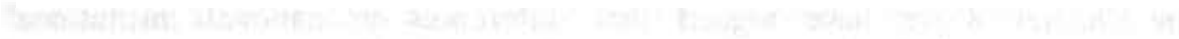

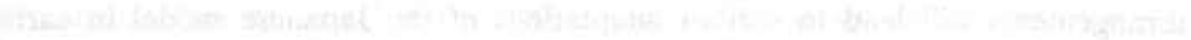

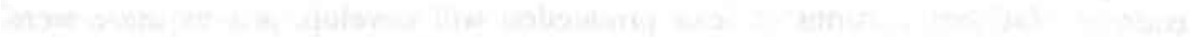

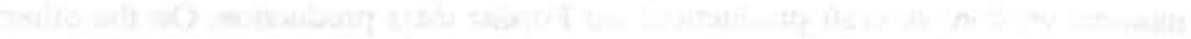
an:

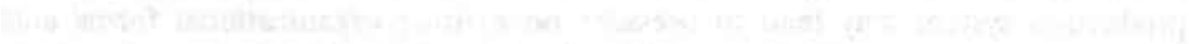

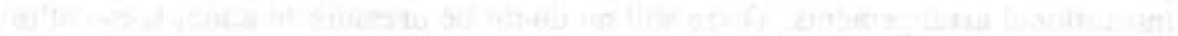

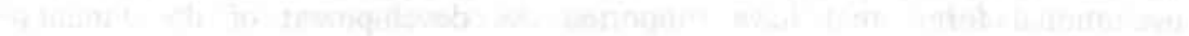

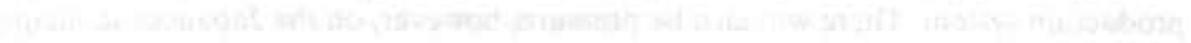

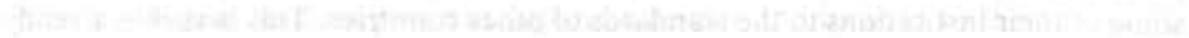

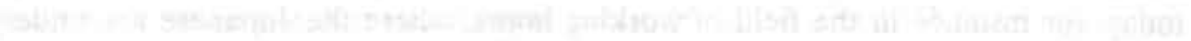

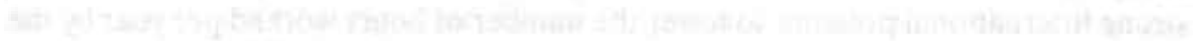

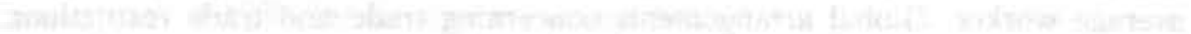

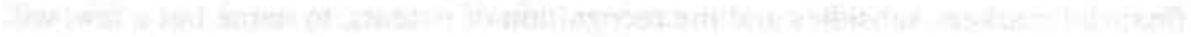

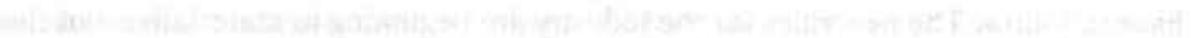

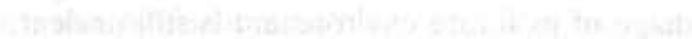

$-$ 


\title{
10. Conclusions and outlook
}

\author{
10.1 Beyond lean production: a new mode of regulation? \\ 10.2 Convergence or divergence? \\ 10.3 The merits of institutional economics \\ 10.4 Outlook: a new regime of accumulation?
}

The search for a new mode of regulation for capitalism is far from over yet. The Japanese production system is functioning as a model for change in the wage relation. No equally appealing model seems to be available for other social relations. Converging tendencies in institutional change, moreover, are constantly upset by new initiatives. The uniformity of global models disintegrates in interaction with the variety of existing national and regional traditions. Institutional economics contributes to our understanding of these processes of search, but leaves the outcome essentially open. Finally, it should be noted that new elements are entering into the debate about the regulation of capitalist accumulation in the future. Growing recognition of the importance of the natural environment is imposing new conditions on economic growth. Search is not just concerned with new institutional forms, but also with the modalities of a new and 'sustainable' regime of accumulation.

\subsection{Beyond lean production: a new mode of regulation?}

In the final section of the previous chapter, our discussion of the future of the automobile industry broadened into a discussion of the future of mass production and the relevance of the Japanese production system for other branches of industry. The MIT-study (Womack et al. 1990) argues that 'lean production' is going to replace Fordism as a production system everywhere. This argument underlines our thesis that the crisis of the automobile industry over the past two decades can be analyzed as part of a larger crisis in the development of capitalist economies. The search for new models in the auto industry is then part of a larger search for new institutional forms for the basic relations of capitalist economies.

A broader understanding of the crisis, such as we have described in Chapter 3 , also makes clear that the discovery of 'lean production' represents only a first step in the long process of construction of a new mode of regulation. It was already observed in the last chapter that the analogy with Fordism would seem to imply that we are now somewhere in the 1920s, with a long stretch of searching ahead of us. In the 1920s, Fordism was mainly a production system, providing new rules for the organization of work and other elements of the wage relation. Industrial unionism was beginning to expand. The macro-social and economic implications 
of Fordism for the organization of other basic social relations were only dimly visible: laws, regulations and jurisprudence concerning the control of mergers and the promotion of competition were still developing; new concepts of retailing and consumer credit were being introduced, but the fundamental revison of the banking system was to come after the 1929 Crisis; new ideas about the role of the state in 'organized' monopoly capitalism were still below the surface of public debate; the gold standard was still a dogma in international monetary relations and the lessons of German inflation were only just being learnt.

Let us consider briefly current debate about these other basic relations of capitalism as defined by the regulation approach (cf. Chapter 2). Even if we limit ourselves to debate within Europe, we are confronted by a variety of ideas, by widespread uncertainty and hesitations, underlining the point that we are still in the midst of a period of search and (re)construction.

Debate on the competitive relations between firms is characterized by conflicting notions. On the one hand, the European Community authorities are developing an aggressive stand on competition policy, scrutinizing mergers and all kinds of cartellization in the economy, encouraging price competition and contesting state subsidies and protectionist policies. Over the years, governments have used such policies to counterbalance the Fordist tendency towards large market-dominating enterprises. The ambitious program for the completion of the Common Market by the end of 1992 is to a large extent justified by reference to economies of scale, i.e. a typically Fordist argument. On the other hand, the Community is also encouraging cooperation between enterprises in 'pre-competitive' $R \& D$, with a tendency to be increasingly tolerant of cooperation in 'competitive' ranges of R\&D. The firms themselves, moreover, are trying to develop stable relations of cooperation and trust between manufacturers and suppliers of components, emulating what is conceived as a key element of the successful Japanese model. It is increasingly being recognized that future competitive advantages will not be found in economies of scale but in economies of scope. In this perspective, mergers and takeovers take on a different meaning. Market domination doesn't show in monopoly pricing but in the ability to produce a large variety of products to serve all segments of the market. Strategic alliances and networking are seen as an important key to competitive success. Cooperation is often extending far beyond the pre-competitive stages of the innovation process. Where this would seem to imply a diminishing intensity of competition, a contrary movement is also visible. Following the same 'Japanese' model, there is a tendency to decrease the level of vertical as well as horizontal integration in enterprises by the creation of smaller independent business units, the sale or management buy-out of activities that are not considered to be at the core of the enterprise, and a gradual increase of outsourcing. All the new or more independent units are supposed to engage in aggressive competitive behavior. The implications for competition policy of these conflicting tendencies in the competitive relations between enterprises are far from clear.

Concerning the money relation, important decisions have recently been taken concerning the European Monetary Union. These decisions will undoubtedly have 
an enormous impact on the different national economies of Europe. Within a few years, these economies and their governments will lose several degrees of freedom in the management of price stability, economic growth and structural change. Differences in productivity, price and wage levels will become highly visible, with consequences for the behaviour of consumers, trade unions, enterprises and capital, that are difficult to predict, because they are highly interdependent. The impact of the European Monetary Union on the world monetary system is also unclear and will depend on further bargaining and decision making by all major national and international actors.

The creation of a single European market with one currency, maybe even enlarged to include major parts of Eastern Europe, will affect international trade relations, if only by the sheer size of this market. In North America, Canada, the United States and Mexico are moving in a similar direction. It is not clear that Japan will be able to create a comparable free-trade zone in its part of the world. The differences in performance and economic needs between countries in this world region are even larger than in North America or Europe. Their growth potential also seems to be larger, however. How much of that growth will be realized by exports to other world regions remains to be seen. Large and permanent imbalances in trade will be difficult to sustain in a world that is so obviously organized in three major trading blocks. It is quite likely that a substantial amount of trade will be replaced by direct investment and production in each of the world regions. New rules for international trade are currently being developed in the Uruguay Round of GATT. Whatever will be the outcome, it is clear that in the future regime of regulation, as in the past, free trade will remain 'embedded' in a set of complex, written as well as tacit rules and agreements.

Debate is also still wide open on the future relations between the state and the economy. Faith in the potential of Keynesian fiscal policies has dwindled. The crisis of Fordism has also weakened the financial and to some extent the political basis of the welfare state. The failure of Keynesian policies and industrial policies in the 1970s resulted in a renewed political support for the traditional pre-Fordist rejection of state-interventionism in capitalist economies during the $1980 \mathrm{~s}$, epitomized by the names of Reagan and Thatcher. Although the wisdom of their ideas and policies (which didn't always match) has since then been widely questioned, there is little agreement on the new role of the state in the economy. There is no theoretical or empirical reason to assume, however, that the form of the future relation between state and economy will return to that of 19th century capitalism. It remains to be seen, if Japanese practices are going to play the role of a model here, but they would certainly not indicate a diminishing role for government in the economy. The revival of debate on industrial policies in the European Community after the signing of the Maastricht treaty, which for the first time allows for such policies at the Community level, also points in a different direction.

The debate is complicated by the collapse of state socialism in Eastern Europe and the Soviet Union, which seems to support the viewpoint that no good can be expected from state intervention. In this debate, there is often little room for 
differentiation between state socialism and the type of intervention advocated by supporters of the welfare state. The role and powers of the state in an economy without private ownership of the means of production are obviously quite different from those in even the most interventionist capitalist state. The failure of state socialism cannot be used as an argument against state interventionism in a capitalist economy. It may be of interest to note, however, that the failure of state socialism is related to the crisis of Fordism. State socialism as it developed in the Soviet Union in the 1920 s and ' $30 \mathrm{~s}$, was clearly influenced by the simultaneous development of the Fordist regime of accumulation in the capitalist countries. Planning activities of the socialist states in the post-war period were focused clearly on mass production of basic consumer goods and the exploitation of scale economies. There seemed to be many parallels with 'organized capitalism' and even in the 1950 s the idea that these countries would 'overtake' capitalism in the future didn't seem impossible. Only the rise of new technological paradigms, new production systems and the ensuing new forms of world-wide competition in the course of the 1960 s and ' 70 s, i.e. the same factors that called forth the crisis of Fordism, showed that these systems were far less flexible than capitalist economies and couldn't generate the necessary adaptations. The far-reaching integration of economic and political decision making processes in these countries blocked all efforts to search for alternative forms of regulation. The economic crisis then turned into a political crisis that led to the eventual complete breakdown of this non-capitalist version of Fordism.

Let us, finally, return to the wage relation. How much do we know now about the development of this relation in the future? Even if 'lean production' is becoming widely accepted as a new standard for the organization of work in manufacturing, the question must be asked if it is really likely that the same industry that provided the paradigm for work in the twentieth century will also do so in the next century. The twentieth century was the century of the automobile. The unionized worker on the car assembly line became the obvious symbol of the Fordist wage relation. The automobile will no doubt remain an important means of transportation, but will it change and dominate our lives in the 21st century as it did in the course of this century? And can the organization of its production processes remain paradigmatic in a new 'Post-Fordist' era? How important can the 'lean production' model be in an environment where a diminishing minority of workers is actually employed in manufacturing processes? Already in the current debate, the name 'lean production' seems to be a misnomer for something that is obviously extending far beyond the manufacturing shop floor. The designation 'lean enterprise', extending to all supportive and technical departments and activities, is already much better. Still, the problem remains that all discussions on lean production are focused on manufacturing, whereas services have become increasingly important in terms of value added and employment. Wouldn't it be more logical to derive models of the future from the service sector of the economy? Although this may seem logical, current insights suggest that the answer to this question should be negative. The debate about the Japanese production system reflects a growing awareness that real, physical production processes will always remain vital parts of any functioning economy. The idea that economies will become pure service economies is increasingly being rejected, because many 
services only make sense in relation to a manufacturing sector. Service activities that lose touch with manufacturing processes will not survive in the long run. The 'lean production' debate suggests that, on the contrary, competitiveness is related to a close integration of manufacturing and supportive (service) activities. This is not just valid for the enterprise level, but also for the economy as a whole.

\subsection{Convergence or divergence?}

A lot of debate about 'lean production' and other models is concerned with the problem of transferability. Is it possible to take models, that have been developed within a specific environment to deal with specific problems that arose in that environment, and introduce them in a completely different setting with different problems? We have already been concerned with that problem in Chapter 8 . We basically concluded that models, although they have been developed in a concrete historical setting, may be seen separate from that setting and can be introduced elsewhere. In the process of introduction, however, they are likely to be adapted and changed in order to fit better to the new environment. Here, we want to briefly raise the question, whether this results in a worldwide convergence towards one basic model. Or will the local and regional solutions and adaptations result in a divergence of models and trends in different parts of the world?

Recent debate about 'Japanization' sometimes suggests that all advanced economies are converging towards the current model of best practice, i.e. Japan. Our discussion in the preceding section has already made clear that this convergence, if it takes place at all, would be limited to various rules and models making up the wage relation. There are no indications that other institutional arrangements in Japan, its politics, its financial institutions, or its industrial organisation are considered to be worthwhile adopting. On the contrary, closer investigation of these institutional arrangements and their relation to Japan's economic performance (Van Wolferen 1989) have increased the pressure on Japan to change some of these arrangements.

From the perspective of the régulation approach, however, it seems necessary to emphasize the convergence towards a new mode of regulation, where the institutional forms of the basic social relations show clear similarities worldwide. The analogy with Fordism suggests that such convergence would not imply that the institutions are completely identical. There were clearly national models of Fordism, so why shouldn't there be national models of Post-Fordism? That precisely is the question to be raised here. It can obviously be argued that the world has changed since the rise of Fordism and indeed as a consequence of Fordism. More than ever before, it is justified to speak of a world economy. Distances have become increasingly unimportant and communications instantaneous. Corporations view themselves as global actors and recruit their leadership accordingly. Will there be room for national variety and localized solutions in a global economy? Wasn't variety simply a result of bad communications and lack of competitive pressures? If communications improve 
and competition becomes global, won't variety disappear to make place for worldwide adoption of the same best practice models?

There are two opposite ways of looking at these questions. I call them the 'Ohmae view' and the 'Porter view' in reference to two popular contributions to the globalization debate. In his influential book on 'Triad Power', Kenichi Ohmae (1985) emphasizes the convergence view of globalization. He notes that consumers in all industrialized countries become more and more alike. The younger generation is everywhere behaving like 'Californians': listening to the same music, wearing the same clothing and buying the same products. Operating on this global market requires a global presence. It is no longer possible to introduce products first in the home market and then slowly introduce them in other places. Communication lines are short and technological knowledge is widely available to potential imitators and competitors. Only global players therefore will be able to reap the full benefits of whatever new ideas and products their research departments come up with. Ohmae's main point is that such a global presence cannot be achieved by means of trade. The average consumer doesn't care where products are made, but their governments do. Protectionist policies of governments force enterprises to become 'insiders' in all parts of the 'triad', i.e. the three major economic regions of the world: in Japan, North America and Western Europe. Of course, Ohmae is aware of the fact that consumers have not become completely identical all over the world. He also sees the advantages of a local presence to cater to these differences. In essence, however, the 'Ohmae view' says that consumers and circumstances are basically the same everywhere and if governments wouldn't insist on the creation of economic power blocks, convergence to a single model would be even more striking.

The Ohmae view of globalization is really the classical view of the economist: the market is universal and governments are only complicating the picture. The 'Porter view' is quite different. In his study of 'the competitive advantage of nations', Michael Porter (1990) emphasizes the importance of differences between national economic systems. These differences form the basis for international competitive advantage of industries and enterprises located in these countries. If governments have a clear understanding of the specificities of their national economies, they may be able to influence the competitive advantage of their nation's economic activities in the world. Of course, Porter does not deny the importance of globalization. Indeed, global competition is the backdrop to his whole argument. Global competition in this view, however, doesn't eliminate differences between nations, but is based upon those differences. Governments and national economic systems are not to be seen as complicating factors, slowing down and hindering the process of globalization, but as essential elements of the same process. In this view, the engine of globalization is variety, and variety is to be found in the differences between nations. there may be converging tendencies, but they will be broken time and again by the competitive advantage of variety.

No need to say that Ohmae and Porter have more to say than has been presented above. Their names and work are used here to sketch out two different views on the issue of convergence versus divergence. To some extent, these two views can 
be considered as two sides of the same medal. Convergence is the result of global competition, but variety (divergence) is the main instrument of competition. This may be called the Schumpeterian view of these issues. In his theory of economic development, Schumpeter (1980, first published in German in 1911) has emphasized the importance of innovations (variety) for economic development. In the absence of innovations, economies would converge towards equilibrium in which no economic development takes place. In Schumpeter's view, that would also signify the end of capitalism in any meaningful sense of the word. Thus, both convergence and diversity are essential elements of capitalist development. The converging tendencies emphasized by Ohmae are based on the diffusion of consumer goods and consumer culture. The divergence emphasized by Porter arises from the variety of economic and social institutions that can be found in the world. In the history of capitalism specific national institutions and organizational forms have served as models for other countries. New models will also arise in the future. As in the past, they may be expected to come from parts of the world that are somewhat isolated, not subjected to the full force of converging tendencies, but somewhere at the margins of current developments.

The 'Ohmae view' of globalization and convergence finds powerful support in the rise of multinational and indeed increasingly global companies and in the dominance of American culture in the world. Nevertheless, in a study on the crisis of Fordism, it is fitting to ask if these tendencies were part of Fordism, and if they are going to survive the crisis of that mode of regulation. The completion of the European Common Market and the Uruquay Round of GATT: are they the last, increasingly hesitant and stumbling steps in a course that has already ended, or are they building blocks in a new mode of regulation? The recent resurgence of nationalism and xenophobia in Europe: is it a temporary phenomenon or does it signify a human need for security and togetherness that has been threatened by the forces of globalization? More questions than we can answer here, but it can certainly be concluded that in the search for new 'Post-Fordist' institutions the forces working against convergence towards one particular model will be far more powerful than expected by the advocates of globalization.

Concepts like 'lean production' have a global meaning. As a result, the search for new organizational forms moves in the same direction everywhere. Concepts, however, have to be applied in the solution of practical problems that differ according to the prevailing circumstances. Global concepts, that is, are being used in local solutions. If we stand back far enough, we see only convergence, but the substance of economic development is made of innovation and divergence. Local solutions will be different in each locality. The global concepts are filled with the substance of local knowledge and local conditions. Where managements and governments neglect the need for local solutions, where foreign models are simply copied instead of understood, competitiveness will deteriorate. 


\section{3}

The conceptual framework of this book has been provided by the so-called régulation approach, which has been presented in Part I as a specific approach in institutional economics. Interest in institutionalist approaches has recently been growing, both among economists and in other social sciences (cf. Hodgson 1989; Powell \& DiMaggio 1991). There are basically two ways to interpret this development. On the one hand, it is possible to see the renewed interest in institutions as a logical step in the development of economics as a discipline since the Second World War. On the other hand, one can view this and other, related theoretical developments as the reaction of social scientists to the specific practical problems raised by the economic crisis of the 1970 s and ' 80 s. A brief look at both interpretations will give us the opportunity to underline the merits of institutional economics and its value for our study.

\section{institutionalism and the development of economics}

The exploration, elaboration and refinement of neoclassical analysis in the course of the 1950s and ' 60 s revealed the full range of assumptions and preconditions that have to be fulfilled in order for a pure market economy to work. In reality, these preconditions are never realized. That raises the important question, how real-life, imperfect markets fulfil all the coordinating and allocative functions attributed to them. There are roughly two ways to answer that question. On the one hand, one can argue that markets do not have to be so perfect in order to function adequately. Some ingenuous theoretical constructions have been devised to explain how imperfect markets can still fulfil approximately the same functions as perfect markets. On the other hand, one can argue that so-called market economies, because they are obviously functioning, must be based on other coordinating mechanisms besides the market. That is the basic argument of modern institutional analysis.

And indeed, it turns out that there are a myriad of mechanisms that fulfil important coordinating and guiding functions. They have been given all sorts of names: organizations, routines, rules of thumb, networks, institutions, regimes, trajectories, regulations. For simplicity, let us refer to all these phenomena as 'institutions'. What these institutions have in common is that they constrain and guide behaviour of economic actors. Such constraints can be justified by the limited and fragmentary character of human knowledge: by guiding the perception and interpretation of reality and by limiting the available options for action, institutions help to solve the problem of uncertainty that has been assumed away in the pure neoclassical model.

Some theorists of neoclassical inclination have been prepared to accept this line of argumentation. They accept that agreed-upon rules may be necessary. Hierarchical organizational structures (enterprises), for instance, may be more efficient than markets for the organization of production in an economy where information is neither free nor complete. The business of uncovering information translates into transaction costs. In the wake of Williamson's (1975) exploration of 
the implications of transaction costs, a large volume of research has underlined the efficiency of organizations and other forms of 'governance' of the relations between economic actors. Another, related strain of thought has emphasized that contractual relations must always be based on a set of property rights, i.e. on a set of rules detailing the privileges and obligations connected to ownership (Demsetz 1967; North and Thomas 1973). This literature has shown that the efficiency of 'the' market may vary according to the prevailing property rights - and to the way they are being enforced.

What most of these contributions on transaction costs and property rights have in common with traditional neoclassical analysis is that they retain in some form the assumption of optimizing or maximizing behaviour by individual economic actors. Institutions are seen as constraints on that behaviour. The same assumption of maximizing behaviour, however, is also used to explain these constraints. Institutions (hierarchies, governance structures, property rights) are seen as the efficient and unintended outcome of self-interested behaviour. If institutions would not be efficient, maximizing behaviour of economic actors would automatically lead to changes in the right direction. This 'organic' explanation of institutions (cf. our discussion in Chapter 2) assumes that maximizing behaviour is possible in the absence of institutions. In that sense, it takes markets as being more basic or prior to the existence of institions.

This type of analysis has created some openings in the walls that neoclassical analysis had erected around the economy, isolating it from the rest of society. The social institutions that are allowed to enter, however, are strictly functional appendices to the market. They are basically explained by the imperfections of reality compared to the perfect market and their only purpose is to support the functioning of the market. The result is what Favereau (1991) calls the 'Extended Standard Theory'. In the 'standard theory' markets were seen as the sole source of flexibility in the system, whereas institutions were considered as rigidities, that prevented the market from functioning. In the extended theory, on the contrary, that same rigidity of institutions is seen as a precondition for realizing the flexibility promised by the market.

Flexibility, or the capacity for adaptive behaviour, is an essential element of any system that is to survive in the face of uncertainty. "Institutions," argues North, "reduce uncertainty by providing a structure to everyday life." (North 1990, p.3) In this perspective, institutions have an important cognitive content, which allows actors to interpret their environment. In a similar vein, Orléan (1989) has argued that social institutions (conventions) are necessary to deal with what he calls second order uncertainty, i.e. the occurrence of hitherto unobserved phenomena that do not fit existing representations of reality. The relevant institutions should be seen as heuristics, providing guidelines for behaviour in new and unexpected situations. Whereas traditional neoclassical analysis sees all necessary information becoming available in the form of prices, the extended theory accepts institutions as an additional and indispensable source of information. 
In their survey of the 'new institutionalism in organizational analysis', Powell and DiMaggio (1991) observe a 'cognitive turn' in institutional analysis. They distinguish between old and new institutionalism. The 'old' institutionalism saw institutions as normative rules, to which people were committed, because they had internalized these rules. Modern institutionalism has a cognitive approach to action. Rules are followed, because they allow people to understand their environment. The emphasis on cognitive dimensions of institutions doesn't necessarily mean that institutions provide the actors with a large amount of information. They also enable the actors to get along with less information. They simply direct the attention of the actors to selected aspects of a situation, so that choices and decisions can be made. They provide actors with a common perception of reality, which makes interaction possible. Institutionalization is nothing else but the 'social construction of reality' (Berger \& Luckmann 1967). Although the analysis of Powell and DiMaggio is based on the sociological literature, it shows interesting parallels with developments in economics. The old institutionalism of Veblen for instance contains strong normative elements, whereas the 'new institutionalism' of Williamson is based, among other things, on an analysis of the costs of collecting information.

Favereau (1991) has pointed out that there is a tension in the 'extended standard theory' between the acceptance of this cognitive function of institutions and the continuing adherence to the assumption of maximizing or optimizing behaviour, which is based on complete knowledge of the relevant facts. If uncertainty is accepted as an ubiquitous state of affairs, optimization is impossible and it will be necessary to move further away from the standard theory by introducing satisficing behaviour and bounded rationality. If this is done, however, the idea that the prevailing institutions are the efficient outcome of maximizing behaviour can no longer be maintained. Neither is it obvious that forces exist that push them in that direction. It is here that the new institutionalism is reaching limits that are difficult to surmount within the framework of 'standard theory'. Functionalist explanations of institutions are no longer possible. The almost-congruity of markets and institutions breaks down. Instead, it must be admitted that inefficient institutions may persist for a long time. Societies may be 'locked in' inside specific institutional arrangements that may not be optimal, but generate sufficient support for themselves. Institutions appear as irreversibilities in the economy (Boyer et al. 1991). As a consequence, historical time has to be introduced into the theory. Economics becomes history.

What we have just sketched can be considered as a highly stylized history of postwar institutionalist thinking in relation to the neoclassical framework. In a way, debate seems to have gone through a full circle. After four decades of theorizing, the new institutionalism has come back to the concerns of the classical institutionalists of the first half of this century: back to the problems of historical 
fashioned questions and concepts of various disequilibrium and evolutionary views (re)gain in status and influence.

It is against that background that the régulation approach has developed. At first, the régulation school concentrated on explaining the extraordinary period of postwar stability and growth. It explored the historical development and international diffusion of the institutions that had regulated the Fordist regime of accumulation. The analysis also pointed to an explanation of the crisis of the '70s. If growth and stability had been dependent on a series of institutions, the breakdown of growth had to be related to limits in the regulative capabilities of these institutions. Consequently, there would be no way out of the crisis without institutional change. The period of high economic growth rates had been one of slow institutional change. The years of slow growth would be years of major institutional changes.

In the course of the 1970s and ' 80 s economists of the regulation school became increasingly involved in the debate about the future institutional forms of capitalism (e.g. Boyer 1989). They were the natural opponents of the idea that the economic problems could be solved, if only 'the market would be allowed to do its job'. It was not that they doubted the organizational capacities of the market. Institutionalists simply point out that the market cannot be considered in isolation. Its workings always depend on the institutional environment. How the market does its job and if it can do it at all, depends on the rules by which the game of the market is played. 'Leaving everything to the market' means that possible changes in the rules are not going to be part of public debate about economic policy. Institutionalist analysis makes clear that this is an important political choice: one that may or may not lead quickly out of a crisis, but certainly not the only choice possible.

Institutionalist analysis and the régulation school in particular have brought a sense of history and the notion of choice to the debate about the future of capitalism. Their contribution could not consist of accurate predictions, based on wellbehaving deterministic models of the economy, the point being that the institutions underlying the regularities on which such models can be based had just broken down. What they could offer were insights provided by historical parallels, a conceptual framework outlining the basic institutions of capitalism and their mutual relations, and the clear understanding that any new institutions making up a new mode of regulation would have to be compatible with the requirements and the logic of whatever regime of capitalist accumulation would eventually emerge.

Institutionalist analysis combines a clear understanding of the importance of irreversibilities in economic development with a sense of freedom and choice. Economic actors are prisoners of the past. Past choices and decisions appear to them in the form of rules, conventions and organizational structures that guide and determine their behaviour. Standards have been set, organizations formed, norms accepted and habits developed. They represent a myriad of irreversibilities in economic life. The régulation school, however, emphasizes that such irreversibilities are not eternal. Of course, history cannot be repeated and in that sense every historical decision is irreversible. In the history of economic 
development, however, institutional irreversibilities are a matter of decades (Boyer et al. 1991). Every now and then opportunities arise to change the organization of the economy and to create new irreversibilities. These opportunities are greatest in times of crisis, when accumulation breaks down and a search for explanations and solutions starts. "Times of crisis are times of great freedom" (Gorz 1983, p.11). It is one of the merits of the institutionalist analysis of economic development that it has never been willing to sacrifice this notion of freedom to the temptations of a deterministic model of economic development.

\subsection{Outlook: a new regime of accumulation?}

Throughout this book, we have treated the crisis of Fordism as a crisis of the mode of regulation, as defined by the régulation school. We have just discussed how new institutional forms are developing for all the basic relations of capitalism. In Chapter 2, however, we have pointed out that the phenomenon of crisis may not be limited to the institutional forms of social relations, but may also extend to the regime of accumulation itself. Are there any reasons to assume that the crisis of Fordism is also a crisis of the regime of accumulation? Is it likely that the regularities of a future growth path will be substantially different from those of the past 40 years?

There are indeed some signals that point in that direction. It was not a coincidence that the first oil crisis, which brought the crisis of Fordism into the open, and public debate on the 'limits to growth' report of the Club of Rome occurred at about the same time. Fordism represented a period of unsurpassed growth for capitalism. The Club of Rome simply pointed out that continuous growth will at some point become physically impossible. Although the problem of physical limits has since then moved somewhat to the backstage of the debate, it has become increasingly clear throughout the 1980 s that nature is not just a resource, but that mankind itself is part of nature. Long before natural resources will be depleted, economic development will run into other, ecological limits. The continuous destruction of nature by mankind is in the end self-destruction. Now that the contradiction between state socialism and capitalism has become a thing of the past, the contradiction between nature and the industrial economy is becoming a main focus of political discourse. A quickly growing range of laws, regulations, agreements and treaties concerning the protection of the environment is changing the face of the political economy.

What does that mean for the regime of accumulation? Let us recall the 'stylized facts' of Fordism: the national product is divided up between capital and labour and the shares of both parties remain roughly the same over time. With a constant capital-output ratio this means that wages can rise with productivity, while the profit rate remains constant. Things become more complex, if we introduce nature as a third factor of production (Immler 1985, 1989). Nature is a necessary part and precondition for every production process. It is much more, however, than the factor 'land' that is sometimes included in textbook treatments of production functions (and thereafter immediately forgotten). It extends even beyond what is 
usually called the 'natural environment' of mankind. 'Nature' refers to the total ecological system of which mankind is a part.

Two important observations can be made concerning this factor of production. The first is that nature cannot be owned and has no price, no monetary value. That makes for an important difference with the other factors of production. The owners of capital will do whatever they can to ensure that their income more than covers the replacement of used-up capital goods. Similarly, workers will fight for wages that at least allow them to stay alive. No owner of nature, however, is fighting to keep nature alive. As a consequence, in most economic theorizing, we find only attention for the rewards of capital and labour. The national product is divided up between the two. Because nature has no price, far too much of it is being used up in production (and in consumption as well). It has become widely recognized by now that this cannot go on. Various mechanisms are being developed to make the use of nature costly. A variety of rules and regulations has been developed aiming at the reduction of environmental pollution. Some form of control and enforcement of those rules by sanctions is needed, because the individual actor may gain from non-compliance. The total costs of compliance and control give a first indication of what might be called the price of nature. In fact, these costs represent the price society is presently willing to pay for not using nature. Depending on the quality of the regulations and the effectiveness of ruleenforcement, nature may be saved (in the sense of being used up less rapidly) or, at the limit, survive 'untouched'.

The second observation, less familiar than the first, is that we can consider nature not just as a resource to be used, but also as one to be (partly) produced. Nature in the romantic sense of the word, the untouched world outside human society, hardly exists anymore and certainly not in Europe. Nature as we know it, is already to a large extent a 'product' of human activities. In the case of the labourer, we know that the wage-goods needed to keep him alive do not prevent him from dying (of old age), but they contribute to the reproduction of the labouring class. The production of capital goods doesn't prevent capital goods from wearing out, but it allows for their replacement. Let us consider the possibility of producing nature to replace the nature that we are and have been destroying. A natureproducing industry can be considered as any other industry, consisting of firms, using capital goods, labour and nature in its production process. The difference with other industries is that it is producing more nature than it is using, just like the capital goods industry is producing more capital goods than it is using up in their production. Some already existing firms and activities can be considered to belong to this industry. Think for instance of the cleaning of polluted soil and waters, the reconstruction of countryside after strip mining, (re)foresting, the fighting of erosion and of expanding deserts, the construction and management of natural parks, etc. One could easily add to this list and a large part of the agricultural sector would probably be interested in a nature producing and conserving role, if only it would be more rewarding.

The problematic side of a nature-producing industry is not its supply side, but it is demand. Beciuse nature is not receiving any income it cannot buy the activities 
needed for its reproduction. If nature is to be re-produced, it needs to be rewarded. Over and above the price that society is paying for not using nature, a price will have to be paid for the nature that is being used. Paying that price will consist of the creation of effective buying power for nature-producing activities. As in the case of nature-saving rules and regulations, the creation of this buying power will have to be a political decision-making process. The reward of nature will then appear as a tax on income of the other factors of production. The price of nature, in the classical sense of the term, i.e. the means necessary to reproduce used-up nature, will be difficult to determine, but that is true for labour as well. In modern two-sector models of the economy, the final determinants of the wage and profit rates lie outside the economic system. The same will be true for the reward of nature.

There is a long tradition in economic theory that differentiates between two sectors: one making consumer goods and one making capital goods. The products of the capital goods sector are bought by capitalists in both sectors to replace and/or enlarge the stock of capital goods in use. The consumer goods are bought by workers and capitalists out of wages and profits respectively. Obviously, stability in the economy is only ensured if supply and demand are equal for both kinds of goods. Karl Marx put a great deal of effort into the investigation of these stability conditions. Almost a century later, the same 'problematique' was taken up by the Keynesian economists. As we have seen, Nicholas Kaldor has distinguished between a 'marxian' and a 'keynesian' economy (Chapter 2). In both types of economy the per capita national product is rising because of rising productivity (technical change), but in the marxian economy the share of wages is diminishing as wages remain at subsistence level (i.e. at the level where labour is merely 'reproduced'), while in the keynesian economy, wages are rising pari passu with productivity. Kaldor shows, that beyond a certain level of income, the share of profits doesn't need to grow anymore in order to provide the investment funds necessary for economic growth (assuming a fixed capital-output rate). A stable economy is then characterized by a constant profit rate and a constant share of wages. That is the characterization of the Fordist regime of accumulation. If we introduce into this picture a third factor of production (nature) and a third sector producing nature, it is clear that the size of the third sector will depend on the reward given to nature. One way to close the system is to fix both the profit rate and the wage rate. The result is an economy in which the share of nature is constantly growing (with growing productivity), much in the same way that the share of profits grew in the marxian economy.

Let us consider the politics of this picture. From the viewpoint of labour, it looks like a return to marxian 19 th century capitalism. Although the wage rate is now well above the subsistence level, the share of wages in national income is decreasing. If at all, this situation will only be acceptable to wage-earners, if the share of profits is not increasing, i.e. if the share of nature is clearly and visibly rising, and if most profits continue to be invested. The constancy of the average wage rate will also require major changes in the organization of the labour market, as upward movements in one place will have to be compensated by downward movements elsewhere. Fighting over the division of income between different 
categories of wage-earners may intensify. The role of the state as an arbitrator may well increase under these circumstances.

To these 'marxian' politics of income distribution must now be added the more 'keynesian' politics of the organization of a demand for nature-producing activities. The most obvious parallel is government spending for defense. Defense is an activity that is supposed to produce a specific environmental quality ('peace'). Contributions to the production of 'peace' are made by private firms (producing weapons for instance) as well as by state organizations like the armed forces. The example makes clear that financing is probably not the key issue. One can think of various ways of collecting taxes to finance the demand for nature (and the politics of income distribution discussed above will be affected by the choices made). The key issues are the definition of worthwhile productive activities (setting priorities), the division of labour between public and private agencies in the production process and the establishment of effective methods and cost-controls to ensure that wages and profits in the nature-producing sector are at normal levels. It is conceivable that in the course of time, the share of nature in national income reaches a point where it is no longer necessary for it to grow, just like the share of profits stopped growing in the course of the 19th century. That may be the occasion for another crisis in the regime of accumulation.

If the advanced capitalist economies want to avoid the further destruction of nature, which in fact is necessary for their own long-term survival, they will have to follow a different regime of accumulation that allows for the regeneration and reproduction of nature. This will require an appropriate mode of regulation. The regularities of a regime of 'sustainable development', as it is called, will be different from those of the era of mass production and mass consumption and they will have to be generated by different behaviour, different routines, different institutions. It is quite likely, therefore, that the post-Fordist mode of regulation will change much more and far more thoroughly than is suggested by the debate about the Japanese production model. A view of the economy from the perspective of a single industry, even if it is as important as the automobile industry, necessarily leads to limited and possibly wrong conclusions. The régulation approach has provided us with a corrective theoretical framework. It has supported our analysis of developments in the automobile industry as reflections of macroeconomic and social changes. It has allowed us to see institutional innovations in the auto industry as models for other industries. It now reminds us that the future of the automobile industry is also determined by outside forces, certainly also by the forces working for a new regime of sustainable development. 


\section{References}

Abernathy, William J., 1978, The Productivity Dilemma: Roadblock to Innovation in the Automobile Industry, Jobn Hopkins University Press: Baltimore .

Abernathy, William J.; Clark, Kim B.; Kantrow, Alan M., 1983, Industrial Renaissance: Producing a Competitive Future for America, Basic Books, Inc. Publishers: New York.

Abramovitz, M., 1983, Notes on differences in productivity growth rates, in: Dennis Mueller (ed.), The political economy of growth, Yale University Press: New Haven/London, pp. 78-89.

Adam, G., 1973, Multinational Corporations and Worldwide Sourcing, in: H. Radice (ed.), Intemational Fims and Modem Imperialism, Penquin Books: Harmondsworth.

Aglietta, Michel, 1979, A Theory of Capitalist Regulation: The US Experience, NLB: London.

Aglietta, Michel, 1982, World Capitalism in the Eighties, New Left Review, No. 136, November/December, pp. 5-41.

Altshuler, Alan; Anderson, Alan; Jones, Daniel; Roos, Daniel; Womack, James, 1984, The Future of the Automobile, George Allen \& Unwin Lid.: London and Sydney.

Armstrong, P.J.; Goodman, J.F.B.; Hyman, J.D., 1981: Ideology and Shop-Floor Industrial Relations, Croom Helm: London.

Arrow, Kenneth, 1974, The Limits of Organization, Norton: New York.

Arthur Anderson \& Co; Prof. Dr. Horst Wildemann, 1988, Die Deutsche Automobilindustrie, Ein Blick in die Zukanft, Frankfurt

Auer, Peter; Penth, Boris; Tergeist, Peter, 1983, Abeitspolitische Reformen in Industriestauten. Ein internationaler Vergleich, Campus Verlag: Frankfurt/New York.

Auer, Peter; Riegler, Claudius H., 1988, Gruppenarbeit bei Volvo: Akhuelle Tendenzen und Hintergnünde, Arbetsmiljöfonden/WZB: Stockholm/Berlin.

Automobil Produktion (AP), various issues.

Automotive News, 1987, 'Progressive' work pacts split UAW; lasting anger is feared, 6.4.1987.

Bailey, John, 1983, Job design and work organisation. Matching people and technology for productivity and employee involvement, Prentice Hall: Englewood Cliffs, NJ.

Balassa, B., 1977, Effects of Commercial Policy on International Trade, The Location of Production and Factor Movements, in: B. Ohlin et al.: The Intemational Allocation of Economic Activity, Holmes \& Meier: London.

Banville, Etienne de; Chanaron, Jean-Jacques, 1991, Vers un systeme automobile européen, Economica: Paris.

Barber G.; Lansbury R., 1987, Codetermination and technological change in the German automobile industry, in: New Technology, Work and Employment, Vol. 2, pp. 160-171.

Barnett, R.J.; Müller, R.E., 1974, Global Reach: The Power of the Multinational Corporations, Simon and Schuster, New York.

Bennett, D.; Sharpe, K. E., 1979: Transnational Corporations and the Political Economy of Export Promotion: The Case of the Mexican Automobile Industry, International Organization, Vol. 33, No. 2.

Berger, Peter L.; Luckmann, Thomas, 1967, The social construction of reality, Doubleday: New York.

Berggren, Christian, 1991, Von Ford Zu Volvo: Automobilhersfellung in Schweden, Springer-Verlag: Berlin.

Bhaskar, K., 1980, The Future of the World Motor Industry, Nichols Publishers: London.

Block, Fred L., 1977, The Origins of Intemational Economic Disorder, University of California Press: Berkeley. 
Bludau, Herbert; Doleschal, Reinhard, 1988, Just-in-Time Logistiek: Neue Handlungsbedingungen und Handlungsanfordenungen für Betriebsräte in der Automobilindustrie und deren Zulieferfimen, Paderborn, 16 März.

Boccara, Paul et al., 1972, Der Staatsmonopolistische Kapitalismus, Dietz Verlag: Berlin.

Bochum, Ulrich; Meißner, Heinz-Rudolf, 1988a, Ende des Aulobooms? Hintergrundpapier aus dem Forschungsprojekt Logistikkonzepte, FAST: Berlin, February.

Bochum, Ulrich; Meißner, Heinz-Rudolf, 1988b, Entwicklungen in der Automobilzulieferindustrie, FAST-Studie, No. 9, Berlin, November.

Bochum, Ulrich; Meißner, Heinz-Rudolf, 1988c, Vor der Talfahrt, Die Situation der Automobilindustrie, Sozialismus, No.4, pp. 4-19.

Bochum, Ulrich; Meißner, Heinz-Rudolf, 1988d, Verbundfertigungen, Beschaffungslogistik und die Verringung der Fertigungstiefe, FAST-Studie, No. 8, Berlin, August.

Bochum, Ulrich; Meißner, Heinz-Rudolf, 1989, Das Euro-Flexible Untemehmen, FAST-Studie, No. 11, Berlin, April.

Booz, Allen \& Hamilton Inc., 1987, Opportunities for Promoting the Dutch Automotive Supply Industry, Ministerie van Economische Zaken: Den Haag, February.

Bourdieu, Pierre; Passeron, Jean-Claude, 1970, La Reproduction, Les Editions de Minuit, Paris.

Bowles, Samuel; Gordon, David M.; Weisskopf, Thomas E., 1984, Beyond the Waste Land: $A$ Democratic Altemative to Economic Decline, Anchor Press/Doubleday: Garden City/New York.

Boyer, Robert, 1986, Theorie de la Regulation: Bilan, Critiques, Perspectives, manuscript, Aout.

Boyer, Robert, 1988a, Technical Change and the Theory of 'Regulation', in: Dosi et al. (ed.), Technical Change and Economic Theory, Pinter Publishers: London/New York, pp. 67-94.

Boyer, Robert, 1988b, Formalizing Growth Regimes, in: Dosi et al. (ed.), Technical Change and Economic Theory, Pinter Publishers: London/New York, pp. 608-630.

Boyer, Robert, 1989, New Directions in Management Practices and Work Organisation. General Principles and National Trajectories, paper for the OECD-Conference on 'Technological Change as a Social Process', Helsinki, 11-13 December.

Boyer, Robert; Chavance, Bernard; Godard, Olivier, 1991, La dialectique réversibilité-irréversibilite: une mise en perspective, in: Robert Boyer et al. (ed.), Les figures de l'irréversibilité en économie, Éditions de l'EHESS, Paris, pp. 11-33.

Boyer, Robert; Coriat, Benjamin, 1987, Technical Flexibility and Macro Stabilisation: A Tentative Analysis, No. 8731, Cepremap: Paris, October.

Braverman, Harry, 1974, Labor and Monopoly Capital. The degradation of work in the twentieth century, Monthly Review Press: New York.

Burns, T, R,; Baumgartner, T.; Deville, P., 1985,: Man, Decisions, Society, Gordon and Breach: New York etc.

Caves, R. E., 1971, International Corporations: The Industrial Economics of Foreign Investment, Economica, No. 38, pp. 1-27.

Cherry, Richard L., 1982, The Development of 'General Motors' Team-Based Plants, in: Robert Zager \& Michael P. Rosow (ed.), The Innovative Organisation: Productivity Programs in Action, Pergamon Press: New York, pp. 125-148.

Clark, Kim B.; Fujimoto, Takahiro, 1991, Product Development Peformance. Strategy, Organization, and Management in the World Auto Industry, Harvard Business School Press: Boston.

Cohen, R., 1982, Intemational Market Positions, Intemational Investment Strategies and Domestic Reorganization Plans of the US Auto-makers, paper International Policy Forum, Hakone.

Commerzbank, 1987, Kfz-Teile-Industrie und Zubehör im Aufwind,: Brancheninformation, 14 September.

Committee on Technology and International Economic and Trade Issues, Automobile Panel, 1982 The Competitive Status of the US Auto Industry: A Study of the Influence of Technology in Determining International Industrial Competitive Advantage, Washington DC.

Cornwall, John, 1977, Modem Capitalism: Its Growth and Transfomation, Martin Robertson \& Company Lid.: Oxford.

Cornwall, John, 1990, The Theory of Economic Breakdown: An Institutional-Analytical Approach, Basil Blackwell: Cambridge.

Cusumano, Michael A., 1985, The Japanese Automobile Industry: Technolngy \& Management at Nissan \& Toyota, Council on East Asian Studies, Harvard University: Cambridge/London. 
Dankbaar, Ben, 1987, Social assessment of workplace technology - some experiences with the German program 'Humanization of Work', Research Policy, Vol. 16, pp. 337-352.

Dankbaar, Ben, 1988a, New Production Concepts, Management Strategies and the Quality of Work, Work, Employment \& Society, Vol. 2, No. 1, pp. 25-50.

Dankbaar, Ben, 1988b, Teamwork in the West-German car industry and the quality of work, in: Wout Buitelaar (ed.), Technology and Work, Avebury/Gower: Aldershot.

Dankbaar, Ben, 1989a, Technical Change and Industrial Relations: Theoretical Reflections on Changes in the Automobile Industry, in: Economic and Industrial Democracy, Vol. 10, pp. 99-121.

Dankbaar, Ben, 1989b, Sectoral Govemance in the Automobile Industries of West Germany, Great Britain and France, MERIT-Research Memorandum, No. 89-008, Maastricht.

Dankbaar, Ben; Diepen, Bas van, 1990, Vemieuwing en Herstrukturering bij Volvo Car B.V., MERITResearch Memorandum, No. 90-003, Maastricht.

Demsetz, Harold, 1967, Towards a Theory of Property Rights, American Economic Review, Vol. 57 (May), pp.347-359.

Denison, Edward F., 1979, Accounting for Slower Economic Growth, The Brookings Institution: Washington, D.C.

Dillard, Dudley, 1986, The Institutional Principle of the Principles of Economics, in: Joumal of Economic Issues, Vol. XX, No. 2, pp. 355-363.

Dimmock, Stuart J.; Sethi, Amarjit S., 1986, The Role of Ideology and Power in Systems Theory. Some Fundamental Shortcomings, Relations Industrielles, Vol. 41, No. 4, pp. 738-755.

Doeringer, Peter B.; Piore, Michael J., 1971, Intemal Labor Markets and Manpower Analysis, D. C. Heath and Company: Lexington/Massachusets.

Dohse, Knuth; Jürgens, Ulrich, 1985, Konzernstrategien und internationale Arbeitsteilung in der Automobilindustrie- am Beispiel Ford und General Motors, Mehrwert, No. 26, September, pp. $30-48$.

Dohse, Knuth, Jürgens, Ulrich; Malsch, Thomas, 1985a, Fertigungsnahe Selbstregulierung oder zentralc Kontrolle - Konzernstrategien im Restrukturirungsprozess der Automobilindustric, in: Frieder Naschold (Hg.), Arbeit und Politik, Frankfurt/New York, pp. 49-89.

Dohse, Knuth; Jürgens, Ulrich; Malsch, Thomas, 1985b, From 'Fordism' to 'Toyotism'? The Social Organization of the Labor Process in the Japanese Automobile Industry, Politics and Socicty, Vol. 14 , No. 2, pp. 115-146.

Doleschal, Rcinhard; Dombois R. (eds.), 1982, Wohin Läuft VW? Die Automobilproduktion in der Wirschaftskrise, Rowohlt: Reinbek bei Hamburg.

Doleschal, Reinhard, 1989, Just-in-time-Strategien und betriebliche Interessenvetrretung in Automobil- Zulieferbetrieben, in: Norbert Altmann \& Dieter Sauer $(\mathbf{H g}$.), Systemische Rationalisierung und Zulieferindustrie, Campus: München, Januar, pp. 155-206.

Doleschal, Reinhard, 1989, Die Automobil-Zulieferindustrie in Umbruch, Hans Böckler Stiftung: Düsseldorf.

Doleschal, Reinhard; KJönne, Arno (Hg.), 1989, Just-in-time-Konzepte und Betrichspolitik, Hans Böckler Stiftung: Düsseldorf.

Dore, Ronald, 1973, British Factory Japanese Factory: The Origins of National Diversity in Industrial Relations, University of California Press: Berkeley/Los Angeles Oxford.

Dosi, Giovanni et al. (ed.), Technical Change and Economic Theory, Pinter Publishers: London/New York.

Duijn, J. J. van, 1979, De lange golf in de economie: kan innovatie ons uit het dal helpen?, Van Gorcum: Assen.

Dunlop, J., 1958, Industrial Relations Systems, Southern Illinois University Press: Carbondale/Edwardsville.

Dunn, James A., 1987, Automobiles in International Trade: Regime Change or Persistance?, International Organization, Vol. 41, No. 2, Spring, pp. 225-252.

Durkheim, Emile, 1986, De la division du travail social, Quadrige/Presses Universitaires de France: Paris.

Edwards, R., 1979, Contested Terrain: The Transformation of the Workplace in the Twentieth Century, Basic Books and Heinemann: New York/London.

Eisenstadt, Shmuel N., 1968, Social Institutions: The Concept, in: Intemational Encyclopedia for the Social Sciences, pp. 409-429. 
Fandel, Günter; Reese, Joachim, 1989, Just-in-Time-Logistik am Beispiel eines Zulieferbetriebs in der Automobilindustrie, Zeitschrift für Betriebswirtschaft, Vol. Vol. 59:1, pp. 55-69.

Favereau, Olivier, 1991, Irreversibilités et institutions: problèmes micro-macro, in: Robert Boyer et al., Les figures de l'iréversibilité en économie, Éditions de l'EHESS, Paris, pp. 69-96.

Fennema, M., 1974, Konzentrationsbewegungen in der westeuropäischen Automobilindustrie', in: $\mathbf{K}$. P. Tudyka (ed.): Multinationale Konzeme und Gewerkschaftsstrategie, Hoffmann und Kampe: Hamburg.

Financial Times, 1987, GM to implement flexible working at Bedford plant, 25.7.1987.

Flanders, A., 1975, Industrial Relations: What Is Wrong with the System?, in: B. Barrett et al. (eds.), Industrial Relations and the Wider Society. Aspects of Interaction, Collier Macmillan: London.

Flynn, Michael S., 1982, Differentials in Vehicles' Landed Costs: Japanese Vehicles in the US Marketplace, The University of Michigan, Office for the Study of Automotive Transportation, Working Paper Series No. 3.

Fortune, 1981, Who did Best (and Worst) Among the 500?, 4 May.

Fox, Alan, 1974, Beyond Contract, Faber: London.

Fox, Alan, 1975, Industrial relations: A Social Critique of Pluralist Ideology, in: B. Barrett et al. (eds.). Industrial Relations and the Wider Society. Aspects of Interaction, Collier Macmillan: London.

Freeman, Chris; Clark, John; Soete, Luc, 1982, Unemployment and technical innovation: A study of long waves and economic development, Pinter: London.

Freeman, Chris; Perez, Carlotta, 1988, Structural Crisis of Adjustment: Business Cycles and Investment Behaviour, in: Dosi et al. (ed.), Technical Change and Economic Theory, Pinter Publishers: London/New York, pp. 38-66.

Freimuth, Joachim, 1987, JIT und die neue Arbeitskultur, Fortschrittliche Betriebsführung /IE, Vol. 36 , No. 2, pp. 59-62.

Fröbel, J. et al., 1977, Die neue intemationale Arbeitsteilung, Rowohlt: Reinbek bei Hamburg.

Gilpin, R., 1975, US Power and the Multinational Corporations, Basic Books: New York.

Glyn, A.; Sutcliffe, B., 1974, Die Profitklemme, Rotbuch Verlag: Berlin.

Goldschmidt, N., 1980, The US Automobile Industry, Report to the President of the USA, Washington DC.

Goodman, J. F. B. et al., 1975, Rules in Industrial Relations Theory: A Discussion, Incustrial Relations Joumal, Vol. 6, No. 1, pp. 14-30.

Gordon, David. M.; Edwards, R.; Reich, M., 1982, Segmented Work, Divided Workers: The Historical Transformation of Labour in the United States, Cambridge University Press: New York.

Gorz, Andre, 1983, Wege ins Paradies. Thesen zur Krise, Automation und Zukunft der Arbeit, Rotbuch Verlag: Berlin.

Gough, Ian, 1979, The Political Economy of the Welfare State, MacMillan Press: London/Basingstoke.

Gramsci, Antonio, 1971, Americanism and Fordism, in: Quintin Hoare \& Geoffrey Nowell Smith (ed.), Selections from the Prison Notebooks of Antonio Gramsci, International Publishers: New York, pp. 279-318.

Granovetter, Mark, 1985, Economic Action and Social Structure: The Problem of Embeddedness, American Joumal of Sociology, Vol. 91, No. 3, November, pp. 481-510.

Guest, Robert H., 1979, Quality of work life - learning from Tarrytown, Harvard Business Review, July/August, pp. 76-87.

Gyllenhammar, Pehr G., 1977, How Volvo adapts work to people, Havvard Business Review, July/August pp. 102-113.

Hackstein, R.; Heeg, FJ., 1986, Kleingruppenaktivitäten in der betreiblichen Praxis, Zeitschriff für wirsschaflliche Fentigung, Vol. 81, No. 1, pp. 30-26.

Halberstam, David, 1987, The Reckoning, Avon Books: New York.

Harcourt, G. C., 1972, Some Cambridge Controversies in the Theory of Capital, Cambridge University Press: Cambridge.

Hayes, R. H.;Abernathy, W. J., 1980, Managing Our Way to Economic Decline, Harvard Business Review, July/August.

Hild, Reinhard, 1986, Japans Druck auf den Pkw-Weltmärkte - Zunehmendes Engagement in Nordamerika und Westeuropa, Ifo-Schnelldienst, No. 33, pp. 7-21.

Hirschman, Albert O., 1977, The Passions and the Interests, Princeton University Press: Princeton. 
Hodgson, Geoffrey M., 1988, Economics and Institutions. A Manifesto for a Modem Institutional Economics, Polity Press: Cambridge.

Hoffman, Kurt; Kaplinsky, Raphael, 1988, Driving Force: The Global Restructuring of Technology, Labor, and Investment in the Automobile and Components Industries, Westview Press: Boulder.

Hounshell, David A., 1984, From the American System to Mass Production, 1800-1932: The Development of Manufacturing Technology in the United States, Johns Hopkins University Press: Baltimore/London.

Hübner, Kurt, 1989, Theorie der Regulation, Edition Sigma/ Wissenschaftszentrum Berlin: Berlin.

Hyman, Richard, 1978, Pluralism, Procedural Consensus and Collective Bargaining, British Joumal of Industrial Relations, Vol. 16, No. 1, pp. 16-40.

Hymer, S., 1960, The Intemational Operations of National Fims: A Study of Direct Investment, Cambridge/Massachusetts.

IG Metall, 1986, Betriebliche Daten' Vergleichstabellen aus Werken der Automobil Industrie, Frankfurt.

IG Metall, 1988a, Die Entwicklung der Fentigungstiefe in der Autoindustrie, Eine Information der Vorstandsverwaltung Wirtschaftsabteilung, Frankfurt, April.

IG Metall, 1988b, Fertigungstiefe der Automobilindustrie, Vorstandverwaltung Wirtschaftsabteilung, Fortschreibung des Papiers vom April 1988, Frankfurt, Juli.

Immler, Hans, 1985, Natur in der ökonomischen Theorie, Westdeutscher Verlag: Opladen.

Immler, Hans, 1989, Vom Went der Natur, Westdeutscher Verlag: Opladen.

Johnson, Chalmers, 1982, MITI and the Japanese Miracle: The Growth of Industrial Policy, 1925-1975, Stanford University Press: Stanford.

Johnston, W., 1982, Issues in Multinational Souncing of Production, paper International Policy Forum, Hakone.

Jones, D.T., 1982, Maturity and Crisis in the European Car Industry, Brighton.

Jones, Daniel; Womack, James, 1988, The real challenge facing the European motor industry, Financial Times, 28.10.1988.

Jürgens, Ulrich; Malsch, Thomas; Dohse, Knut, 1989, Modeme Zeiten in der Automobilfabrik: Strategien der Produktionsmodemisierung im Länder- Konzernvergleich, Springer-Verlag: Berlin.

Jürgens, Ulrich; Reutter, Werner, 1988, Verringenung der Fentigungstiefe und betriebliche Interessenvertretung in der deutschen Automobilindustrie, Wissenschaftszentrum Berlin: Berlin.

Jürgens, Ulrich; Strömel, Hans-Peter, 1987, The Communication Structure between Management and Shop Floor: A Comparison of a Japanese and a German Plant - European and Japanese Perspectives, in: Malcolm Trevor (ed.), The Intemationalization of Japanese Business, Campus/Westview:Frankfurt am Main/Boulder/Colorado, pp. 92-110.

Kaldor, Nicholas, 1972, The Irrelevance of Equilibrium Economics, Economic Joumal, December, pp. 1237-1255.

Kaldor, Nicholas, 1980, Capitalist Evolution in the Light of Keynesian Economics, in: N. Kaldor, Essays on Economic Stability and Growh, Second Edition, Duckworth: London, pp. 243-258.

Kamata, Satoshi, 1986, Japan aan de lopende band, Uitgeverij Jan Smets: Amsterdam.

Katz, Harry C., 1984, The U.S. Automobile Collective Bargaining System in Transition, British Joumal of Industrial Relations, Vol. 22, No. 2, pp. 205-217.

Katz, Harry C., 1985, Shifting Gears: Changing Labor Relations in the U.S. Automobile Industry, MIT Press: Cambridge/Massachusetts.

Katz, Harry C.; Sabel, Charles F.,1985, Industrial Relations and Industrial Adjustment in the Car Industry, Industrial Relations, Vol. 24, No. 3, pp. 295-315.

Kern, Horst; Schumann, Michael, 1984, Das Ende der Abeitsteilung-Ratio-nalisierung in der Industriellen Produktion, Bestandaufname, Trendbestimmung, C.H.Beck-Verlag: München.

Kleinknecht, Alfred, 1987, Innovation Pattems in Crisis and Prosperity, MacMillan Press: Houndmills.

Knickerbocker, F., 1973, Oligopolistic Reaction and the Multinational Enterprise, Harvard Business: Harvard.

Koch, H. C.; Gericke, E., 1986, Produktplanung und Produktionsforschung für die Montage von Automobilien, Zeitschrift für wirtschaftliche Fertigung, Vol. 81, No. 4, pp. 180-184.

Kochan, Thomas A.; McKersie, Robert B.; Cappelli, Peter, 1984, Strategic Choice and Industrial Relations Theory, Industrial Relations, Vol. 23, No. 1, pp. 16-39.

Kraar, L., 1983, The Third World's Bid to Export Cars, Fortune, 5 September. 
Krafcik, John F., 1988a, Comparative Analysis of Performance Indicators at World Auto Assembly Plants, Massachusetts Institute of Technology.

Krafcik, John F., 1988b, Triumph of the Lean Production System, Sloan Management Review, Fall, pp. 41-52.

Lall, S., 1980, The International Automotive Industry and the Developing World, World Development, Vol. 8, pp. 789-812.

Lamming, Richard, 1989, The Causes and Effects of Siructural Change in the European Automotive Components Industry, International Motor Vehicle Program, Massachusetts Institute of Technology: Cambridge, May.

Landen, D. L.; Carlson, Howard C., 1982, Strategies for Diffusing, Evolving, and Institutionalizing Quality of Work Life at General Motors, in: Robert Zager \& Michael P. Rosow, The Innovative Organisation: Productivity Programs in Action, Pergamon Press: New York, pp. 291-336.

Lawler, Edward E., 1986, High-involvement Management, Jossey-Bass: San Francisco and London.

Leborgne, Danièle; Lipietz, Alain, 1987, New Technologies, New Modes of Regulation: Some Spatial Implications, No. 8726, Cepremap: Paris.

Lekachman, Jack, 1966, The Age of Keynes, Penguin Books: Harmondsworth

Lewchuck, W., 1986, The Motor Vehicle Industry, in: B. Elbaum \& W. Lazonick (eds.), The Decline of the Britisch Economy, Clarendon Press: Oxford, pp. 135-161.

Lichtenstein, Nelson; Meyer, Stephen (eds.), 1989, On the Line: Essays in the History of Auto Work, University of Illinois Press: Urbana/Chicago.

Linden, Frans Andreas; Rüßmann, Karl Heinrich, 1988, Kfz- Zulieferer: Die Faust im Nacken, Manager Magazin, Nr.8, pp. 88-109.

Lipietz, Alain, 1987, Mirages and Miracles. The Crisis of Global Fordism, Verso: London.

Lukes, Steven, 1973, Emile Durkheim. His life and work: A Historical and Critical Study, Penguin Books: New York.

Lutz, Burkart, 1984, Der kurze Traum immerwährender Prosperität: Eine Neuinterpretation der industriellkapitalistischen Entwicklung in Europa des 20. Jahrhunderts, Campus Verlag: Frankfurt/New York.

MacLeod, Roy, 1986, Technology and the Human Prospect, Frances Pinter Ltd.: London.

Mahnkopf, Birgit, 1988, Der gewendete Kapitalismus, Verlag Westfälisches Dampfboot: Münster.

Mair, Andrew, 1991, Pars Sourcing at Japanese Automobile Transplants: Controversy in the United States, The case of Honda in North America, Implications for Transplants in Europe, Working Paper No. 2, ESRC Project 'Just-in-time Manufacturing and Spatial Changes in the Automobile Industry: An International Comparison', Department of Geography, University of Durham: Durham, April.

Marsden, David; Morris, Timothy; Willman, Paul; Wood, Stephen, 1985, The Car Indusiry. Labor Relations and Industrial Adjustment, Tavistock Publications: London/New York.

Maxcy, G., 1981, The Multinational Automobil Industry, St. Martin: London.

Mayr, Hans, 1986, IMB-Weltautomobilausschuss für Volkswagen, Referat, Wolfsburg, 1-2 September.

Mazier, J., 1982, Growth and Crisis: a Marxist Interpretation, in: Boltho, A. (ed.), The European Economy: Growth and Crisis, Oxford University Press: Oxford, pp. 39-71.

McCracken, Paul et al., 1977, Towards Full Employment and Price Stability, OECD: Paris.

Mensch, Gerhard, 1977, Das technologische patt, Fischer Taschenbuch Verlag: Frankfurt am Main.

Mickler, O., et al., 1981, Industrieroboter - Bedingungen und soziale Folgen des Einsatzes neuer Technologien in der Automobilproduktion, Campus Verlag: Frankfurt/New York.

Minssen, Heiner; Howaldt, Jürgen; Kopp, Ralf, 1991, Gruppenarbeit in der Automobilindustrie. Das Beispiel Bochum, WSI Mitteilungen, Nr.7, pp. 434-441.

Monden, Yasuhiro, 1983, Toyora Production System: Practical Approach to Production Management, Industrial Engineering and Management Press: Norcross.

Müller, Gernot et al., 1978, Ökonomische Krisentendenzen im gegenwärtigen Kapitalismus, Campus Verlag: Frankfurt/New York.

Muysken, J.; Wagener, H. J., 1986, The Welfare State: From Stabiliser to Destabiliser?, in: W. Albeda (ed.), The Future of the Welfare State, Maastricht, pp. 39-62.

Nelson, R. R.; Winter, S., 1982, An Evohtionary Theory of Economic Change, Belknap, Harvard University Press: Cambridge/Massachusets. 
Nishiguchi, Toshihiro, 1987, Competing Systems of Automotive Components Supply: An examination of the Japanese 'Clustered Control' Models and the 'Alps' Sinucture, Briefing Paper for the First Policy Forum International Motor Vehicles Program, May 5.

Nolan, P.; Edwards, P. K., 1984, Homogenise, Divide and Rule: an Essay on Segmented Work, Divided Workers, Cambridge Joumal of Economics, Vol.8, No. 1, Academic Press Inc.: London, pp. 197-215.

North, Douglas C., 1981, Structure and Change in Economic History, Norton: New York.

North, Douglas C., 1990, Institutions, Institutional Change and Economic Pefornance, Cambridgc University Press, Cambridge.

North, Douglas C.; Thomas, Robert Paul, 1973, The Rise of the Westem World. A New Economic Histony, Cambridge University Press: Cambridge.

Odaka, Konosuke; Ono, Keinosuke; Adachi, Fumihiko, 1988, The Automobile Industry in Japan: A Study of Ancillary Fim Development, Kinokuniya/Oxford University Press: Tokyo/Oxford.

Ohmae, Kenichi, 1985, Triad power: the coming shape of global competition, Free Press: New York.

Olson, Mancur, 1982, The rise and decline of nations: Economic Growth, stagfation and social rigidities, Yale University Press: New Haven.

Orléan, André, 1989, Pour une approche cognitive des conventions économiques, Revue Économique, Vol.40, Nr.2, pp. 241-272.

Ott, A. E. (ed.), 1982, Stntkniprobleme der Weltautomobilindustrie in den 80er Jahren, Verband der Automobilindustrie e.V: Frankfurt am Main.

Piore, Michael J.; Sabel, Charles F., 1984, The Second Industrial Divide: Possibilities for Prosperity, Basic Books: New York.

Polanyi, Karl, 1978, The Great Transfonnation, Suhrkamp Taschenbuch Verlag: Frankfurt am Main.

Poole, Michael, 1981, Theories of Trade Unionism: A Sociology of Industrial Relations, Routledge and Kegan Paul: London etc.

Porter, Michael, 1990, The Competitive Advantage of Nations, Free Press: New York.

Powell, Walter W., 1990, Neither Market nor Hierarchy: Network Forms of Organization, in: B. Staw \& L. L. Cunnings, Research in Onganizational Behavior, JAI Press: Greenwich, Conn., Vol. 12, pp. 295-336.

Powell, Walter W.; Dimaggio, Paul J. (ed.), 1991, The New Institutionalism in Organizational Analysis, University of Chicago Press: Chicago.

Prakke, F., 1989, Automatisering in de fabriek, in Simonse, A., Kerkhoff, W. \& Rip, A., (ed.) Technology assessment in ondememingen. Deventer, Kluwer, 1989.

Robbins, Lionel, 1935, An Essay on the Nature and Significance of Economic Science (2nd edition), London.

Roche, William K., 1986, Systems Analysis and Industrial Relations: Double Paradox in the Development of American and British Industrial Relations Theory, Economic and Industrial Democracy, Vol. 7, pp. 3-28.

Roobeek, Annemieke J. M. , 1988, Een race zonder finisch. De rol van de overheid in de technologiewedloop, VU-Uitgeverij: Amsterdam.

Rosenberg, Nathan; Birdzell Jr., L.E., 1986, How the West Grew Rich. The economic transformation of the industrial world, Basic Books: New York.

Roth, Siegfried; Kohl, Heribert, 1988, Perspective: Gruppenarbeit, Bund-Verlag: Köln.

Rothschild, Emma, 1973, Paradise Lost: The Decline of The Auto-Industrial Age, Random House: New York.

Rothwell, Roy; Zegveld, Walter, 1981, Industrial Innovation and Public Policy, Frances Pinter Ltd.: London.

Ruggie, John Gerard, 1982, International Regimes: Transactions, and Change: Embedded Liberalism in the Postwar Economic Order, in: Intemational Organization, Vol. 35, No. 2, Spring, pp. 379-415.

Ruigrok, Winfried; Tulder, Rob van; Baven, Geert, 1991, Cooperation, Competition, Coalitions and Control: Globalisation and Glocalisation Processes in the World Car Industry, Erasmus University Rotterdam \& University of Amsterdam: Rotterdam/Amsterdam.

Saporito, Bill, 1986, The revolt against 'working smarter', Fortune, July 21, pp. 44-48.

Satoshi Kamata, 1986,: Japan aan de Lopende Band, Jan Mets: Amsterdam

Schienstock, G., 1981,: "Towards a Theory of Industrial Relations" British Joumal of Industrial Relations, Vol. 19, No. 2, pp. 170-189. 
Schonberger, Richard J., 1982, Production line management: A comparative analysis of Japanese vs. Western approaches, in: American Institute for Decision Sciences, 14 h Annual Meeting, Nov. 22-24 1982, San Francisco, Vol. 2, pp. 115-117.

Schonberger, Richard J., 1982, Japanese Manufacturing Techniques: Nine Hidden Lessons in Simplicity, The Free Press: New York.

Schotter, Andrew, 1981, The Economic Theory of Social Institutions, Cambridge University Press: Cambridge.

Schreyögg, Georg, 1980, Contingency and Choice in Organization Theory, Organization Studies, Vol. 1, No. 4, pp. 305-326.

Schumpeter, Joseph A., 1980, The theory of economic development, Oxford University Press: Oxford. Schumpeter, Joseph A., 1986, History of Economic Analysis, Allen \& Unwin: London/Boston/Sydney.

Skinner, Wickham, 1985, Manufacturing. The Formidable Comperitive Weapon, John Wiley and Sons: New York etc.

Sleigh, Paul A. C., 1989, The European Automotive Components Industry: A Review of Eighty Leading Manufacturers, Economist Intelligence Unit, Special Report, Nr. 1186, London, April.

Spero, John Edelman, 1977, The Politics of Intemational Economic Relations, George Allen \& Unwin: Boston/Sydney.

Streeck, Wolfgang, 1986a, Kollektive Arbeitsbeziehungen und industrieller Wandel: Das Beispiel der Automobilindustrie, IIM/LMP 86-2, Wissenschaftszentrum Berlin: Berlin.

Streeck, Wolfgang, 1986b, The Uncertainties of Management in the Management of Uncertainty: Employers, Labor Relations and Industrial Adjustment in the 1980s, IIM/LMP 86-26, Wissenschaftszentrum Berlin: Berlin.

Streeck, Wolfgang, 1988, Successful Adjustment to Turbulent Markets: The Automobile Industry, Wissenschaftszentrum Berlin: Berlin, January.

Scheinecker, Martina, 1988, Neue Organisationskonzepte in der Automobilindustrie: Entwicklungstendenzen am Beispiel General Motors Austria, in: Ben Dankbaar, Ulrich Jürgens \& Thomas Malsch (ed.), Die Zukunft der Arbeit in der Automobilindustrie, Sigma: Berlin, pp. 167-184.

Sweezy, Paul M., 1970, The Theory of Capitalist Development, Modern Reader Paperbacks: New York/London.

The Economist, 1982, Protectionist Overdrive, December 25.

Therborn, Göran, 1976, Science, Class and Society: On the Formation of Sociology and Historical Materialism, NLB: London.

Timperley, Stuart R., 1980, Organization Strategies and Industrial Relations, in: Industrial Relations Joumal, Vol. 11, No. 5, pp. 38-45.

Tolliday, Steven; Zeitlin, Jonathan, 1986, Shop-Floor Bargaining, Contract Unionism and Job Control: An Anglo-American Comparison, in: Steven Tolliday \& Jonathan Zeitlin (eds.), The Automobile Industry and Iis Workers: Between Fordism and Flexibility, Polity Press: Cambridge.

Tolliday, Steven; Zeitlin, Jonathan (eds.), 1986, The Automobile Industry and its Workers: Between Fordism and Flexibility, Polity Press: Cambridge.

UNIDO, 1979, World Industry Since 1960: Progress and Prospects, United Nations: New York.

Vacano, K., 1979, Standortplanung in der Automobilindustrie, Zeitschrift für Betriebswirtschaft, Ergänzungsheft 1.

Van Eijnatten, F. M. et al., 1986, Grenzen voor Produktiecellen. Ervaringen met herformeren van pseudo-autonome groepen in een truck-eindassemblage-fabriek, paper, Katholieke Universiteit Nijmegen: Nijmegen.

Van Wolferen, Karel, 1989, The Enigma of Japanese Power. People and Politics in a Stateless Nation, Macmillan: London.

Veblen, T., 1898, Why is Economics not an Evolutionary Science?, Quarterty Joumal of Economics, Vol. XII, July, reprinted in: J.A. Gherity (ed.), 1965, Economic Thought: A Historical Anthology.

Verhagen, Marinus, 1990, Regulatie, fordisme en de huidige krisis: Een hernieuwde introduktie en bespreking van de ideeën van Robert Boyer en Alain Lipietz, Tijdschnift voor Politieke Economie, Vol. 12, No. 3 (January), pp. 64-92.

Vernon, R., 1966, International Investment and International Trade in the Product Cycle, Quarterly Joumal of Economics, Vol. 80, pp. 190-207. 
Vernon, R., 1979, The Product Cycle Hypothesis in a New International Environment, Oxford Bulletin of Economics and Siatistics, Vol. 41, No. 4, pp. 255-267.

Volkert, Klaus et al., 1987, Qualitätszirkel als Einfallstor für eine Mitbestimmung verstehen, Frankfurter Rundschau, 20.3.1987.

Volkswagenwerk AG et al., 1980, Gruppenarbeit in der Motorenmontage. Ein Vergleich von Ameitsstrukturen, Campus Verlag, Frankfurt/New York.

Volpato, G., 1984, Product Market Changes and Firm Strategies. Paper for the Intemational Conference on the Automobile Industry and its Workers: Past, Present, and Future, Coventry, 28 June - 1 July.

Weber, Max, 1985, Wirtschaft und Gesellschaft, J.C.B. Mohr: Tübingen.

Weisskopf, Thomas E. et al., 1983, Hearts and Minds: A Social model of US productivity growth, Brooking Papers on Economic Activity, No. 2 , pp. $381-450$.

Wells, L.T., 1980, The International Product Life Cycle and United States Regulation of the Automobile Industry, in: D.H. Ginsburg \& WJ. Abernathy (eds.), Govemment, Technology and the Future of the Automobile, McGraw: New York, pp. 270-292.

White, L.J., 1977, The Automobile Industry, in: W. Adams (ed.), The Structure of American Industry, 5th edition, Macmillan: New York.

Wickens, Peter, 1987, The Road to Nissan, MacMillan Press: Houndmills.

Wilkins, M., 1980, Muttinational Automobile Enterprises and Regulation: An Historical Overview, in: Ginsburg \& Abernathy (eds), Govemment, Technology and the Future of the Automobile, McGraw: New York, pp. 221-258.

Wilkinson, S. F., 1984, Segmented Work, Divided Workers: the Historical Transformation of Labor in the United States: Book Review, Contributions to Political Economy, pp. 92-98.

Williams, Karel; Williams, John; Haslam, Colin, 1989, Why Take the Stocks out? Britain vs. Japan, Intemational Joumal of Operations and Production Management, Vol. 9, No. 8, pp. 91-105.

Williamson, Oliver E., 1975, Markets and Hierarchies: Analysis and Anti-trust Implications, Free Press: New York.

Williamson, Oliver E., 1985, The Economic Institutions of Capitalism, Free Press: New York.

Willman, Paul, 1982, The Reform of Collective Bargaining and Strike Activity in BL Cars 1976-1982, Industrial Relations Joumal, Vol. 15, No. 2, pp. 6-17.

Willman, Paul, 1986, Technological Change, Collective Bargaining and Industrial Efficiency, Clarendon Press: Oxford.

Wobbe-Ohlenburg, Werner, 1982, Automobilarbeit und Roboterproduktion. Der einfluss neuer produktionstechnologien auf die struktur der automobilarbeit- Eine fallstudie zum einsatz von industrierobotem im Volkswagenwerk, Verlag Die Arbeitswelt: Göttingen.

Womack, James P.; Jones, Daniel T.; Roos, Daniel, 1990, The Machine That Changed The World, Rawson Associates: New York.

Wood, S.J. et al., 1975, The 'Industrial Relations System' Concept As A Basis for Theory in Industrial Relations, British Joumal of Industrial Relations, Vol. 13, No. 3, pp. 291-308.

Wood, Stephen, 1987, The Deskilling Debate; New Technology and Work Organization, Acta Sociologica, Vol. 30, No. 1, pp. 3-24.

Wormald, Jobn, 1989, Manufacturer Integration and Supplier Relationships, ErU European Motor Business, Nr. 17, May, pp. 144-161

Wrong, Dennis H., 1961, The Oversocialized Conception of Man in Modern Sociology, American Sociological Review, Vol. 26, No. 2, April, pp. 183-193.

Zeilinger, Peter, 1988, Just-in-time and New Logistic Concepts in the Automobil Industry, BMW AG, Mimeo.

Zysman, John, 1983, Govemments, Markets, and Growth, Cornell University Press: Itacha/London. 


\section{Samenvatting}

Dit boek bevat een vijftal reeds eerder gepubliceerde artikelen over ontwikkelingen in de automobielindustrie, ingebed in een institutioneel-economische beschouwing over de crisis van het Fordisme.

Fordisme is de naam die gegeven is aan het produktiesysteem dat in de eerste decennia van deze eeuw door Henry Ford in zijn automobielfabriek werd geïntroduceerd. Het gaat om een systeem van massaproduktie. Meest opvallend kenmerk is dat de (montage)werkzaamheden zijn opgedeeld in een reeks opeenvolgende handelingen van korte en zoveel mogelijk gelijke duur. De werkstukken worden mechanisch langs de arbeiders geleid (de lopende band) met een zodanige snelbeid dat iedere werker precies genoeg tijd heeft on een handcling te verrichten.

Fordisme is cchter ook de aanduiding geworden voor de maatschappelijke instellingen die met name na de Tweede Wereldoorlog in samenhang met de verspreiding van het systeem van massaproduktie in bijna alle ontwikkelde kapitalistische landen tot stand zijn gekomen. Het gaat hier om een complex van instituties, die er tezamen voor gezorgd hebben dat de massaproduktie geconfronteerd werd met een even massale vraag. Te denken valt aan het zogenaamde 'produktiviteitscontract' met de vakbeweging, waarbij de industriële vakbonden het Fordistisch produktiesysteem aanvaardden in ruil voor loonstijgingen die gelijk opgingen met de produktiviteit. Te denken valt ook aan de instituties die het kader vormden waarbinnen de wereldhandel sterk kon groeien: GATT, de overeenkomsten van Bretton Woods. Ook de bereidheid van de overheid om door bestedingsbeleid de koopkrachtige vraag en daarmee de werkgelegenheid op peil te houden en de ontwikkeling van de zgn. verzorgingsstaat worden beschouwd als kenmerkend voor het Fordisme.

Fordisme is met andere woorden een aanduiding voor de instellingen, de industriële organisatie en methoden, die tussen 1950 en 1970 een tot dan toe ongekende periode van groei in de kapitalistische wereld mogelijk maakten. Sinds het cind van de jaren ' 60 is echter sprake van een vertraagde groei. De oliecrisis van 1973 wordt dikwijls gezien als een breukpunt, maar de omslag was al eerder zichtbaar. het tijdperk van ongebreidelde groei was voorbij en naarmate de stagnatie langer duurde begon het woord crisis zijn rentree te maken in politiek-economische beschouwingen.

Het woord crisis was bijna geheel verdwenen uit de hoofdstroom van het economisch denken. Decennia van min of meer evenwichtige groei hadden de traditionele aandacht voor evenwicht in het economisch denken slechts versterkt. In Hoofdstuk 2 wordt uiteengezet dat deze aandacht voor evenwicht naww samenhangt met de exclusieve rol die door de economische wetenschap vanouds is toegekend aan de markt als organisatiemechanisme voor het economisch leven. Zodra de aandacht zich richt op economische crisis en technologische ontwikkeling, d.w.z. op veranderingsprocessen, komen ook andere ordenende instituties in beeld. Met 'institutionele economie' duiden we alle tegenstromen in het economisch denken aan, die erop wijzen dat economisch handelen ingebed is in een reeks van maatschappelijke instituties, die het functioneren van markten als zodanig mogelijk maken. Een recente bijdrage aan het institutioneel economisch denken is de Franse régulation benadering. Het begrippenapparaat van de régulation benadering wordt in Hoofdstuk 3 gebruikt voor een nadere beschouwing van de crisis van het Fordisme. Ook andere analyses van deze crisis worden kort besproken voorzover zij een aanvulling geven op de régulation benadering.

Zowel in Hoofdstuk 2 als in Hoofdstuk 3 wordt uitgebreid stil gestaan bij de analyse van institutionele verandering. Een economische crisis wordt beschreven als een periode waarin gezocht wordt naar nieuwe vormen voor de organisatie van her economisch leven, nieuwe instituties die het economisch bandelen zodanig kunnen reguleren dat een herstel van de groei mogelijk wordt. 
In deel II van dit boek volgen dan de vijf hoofdstukken over ontwikkclingen in de automobielindustrie. Deze hoofdstukken zijn op verschillende tijdstippen en met verschillende optieken geschreven. $\mathrm{Zij}$ kunnen echter ook gelezen worden als 'hoofdstukken in de zocktocht naar een post-Fordistische orde'. Hoofdstuk 4 analyseert hoe de investeringen van de automobielindustrie in ontwikkelingslanden gestuurd werden door overheidsingrijpen. Het wijst er op dat de toenemende handel in de wereld onderworpen is aan een reeks van expliciete en stilzwijgende afspraken, die er toe leiden dat in iedere wereldregio een complete automobielindustrie blijft bestaan. Hoofdstuk 5 gaat in op veranderingen in de arbeidsorganisatie in de automobielfabrieken. Terwijl in het systeem van Ford de arbeidsdeling voorop stond, wordt in moderne organisatieconcepten juist gewerkt aan integratie van taken en de vorming van autonome groepen in de produktie. Hocwcl deze nicuwe concepten ook los van technologische vernieuwing kunnen worden toegepast, zijn ze in de praktijk dikwijls aan technische veranderingen gekoppeld. Hoofdstuk 6 is gewijd aan de implicaties van de toepassing van nieuwe technieken en organisaticconcepten op de arbeidsverhoudingen. Ook hier geldt dat in verschillende landen gezocht wordt naar nieuwe organisatievormen en spelregels om adequaat vorm te kunnen geven aan de ruilverhouding tussen kapitaal en arbeid. Hoofdstuk 7 richt zich dan op de verhoudingen tussen bedrijven onderling. De crisis van het Fordisme heeft met name de relatie tussen autofabrikanten en hun toeleveranciers in beweging gebracht. Ook hicr worden tegen de achtergrond van technologische ontwikkelingen en nieuwe organisatieconcepten nicuwe spelregels ontwikkeld. De vroeger oppermachtige afnemer biedt de toelcverancier een meer gelijkwaardige relatie aan. Hoofdstuk 9 tenslotte gaat in op de vraag of institutionele innovaties die in ecn bepaald land, in dit geval Japan, ontwikkeld zijn, probleemloos kunnen worden overgeplant naar andere landen met andere tradities en instellingen. Institutionele verandering neemt dikwijls de vorm aan van het kopic̈ren van elementen van instituties die elders êffectief lijken te zijn.

De twee hoofdstukken van Deel III bevatten samenvattende beschouwingen over respectievelijk de automobielindustrie en institutionele economie. Hoofdstuk 9 blikt terug op de wijze waarop de crisis van het Fordisme zichtbaar werd in de automobielindustrie. Daarnaast wordt uitgebreid aandacht besteed aan het 'Japanse model', dat door velen gezien wordt als de opvolger van het Fordisme. In de recente debatten daarover ligt de nadruk sterk op alternaticve management concepten. De institutionele benadering benadrukt dat die, voorzover zij echt een fundamenteel nieuw paradigma vertegenwoordigen, zich pas kunnen doorzetten wanneer ook in de maatschappelijke context nieuwe instituties en spelregels gevonden zijn. In hoofdstuk 10 wordt het bedrijfstakperspectief weer verlaten. Teruggrijpend op de discussies in Deel I wordt met behulp van de régulation benadering cen tussentijdse balans opgemaakt van de zoektocht naar nieuwe regels voor een post-Fordistische economische orde. Aan de orde komt ook de vraag of sprake is van convergcrende of divergerende tendenties in de wereld. Een bespreking van recente bijdragen aan de institutionele analyse benadrukt nog eens dat de uitkomst van maatschappelijk zoekprocessen niet gedetermineerd is. In tijden van crisis kunnen echte keuzen gemaakt worden. Aan het eind van dit hoofdstuk wordt tenslotte nog gewezen op de mogelijkheid dat institutionele vernicuwing in het teken zal staan van een geheel ander groeipatroon dan in het verleden. Wanneer de discussie over duurzame ontwikkeling ernstig genomen wordt, zullen institutionele innovaties noodzakelijk worden, die veel ingrijpender zjjn dan de vernieuwingen die nu worden voorgesteld aan de hand van het Japanse model. 


\section{Curriculum Vitae}

Ben Dankbaar werd op 29 juli 1948 geboren te Amsterdam. Tussen 1960 en 1966 volgde hij de Gymnasium-B opleiding aan het Christelijk Lyceum Buitenveldert te Amsterdam. Daarna bezocht hij gedurende een jaar de Liberty High School in Liberty, Missouri, USA. Van 1967 tot 1975 studeerde hij aan de Universiteit van Amsterdam. In 1971 legde hij daar het kandidaatsexamen in de politieke wetenschappen af. In 1975 behaalde hij het doctoraal diploma (cum laude) in de sociale wetenschappen met het hoofdvak theoretische economie.

Van 1976 tot 1982 was hij als wetenschappelijk medewerker verbonden aan het Economisch Seminarium van de Faculteit der Sociale Wetenschappen. Van 1982 tot 1988 was hij werkzaam in West-Berlijn, waar hij betrokken was bij verschillende onderzoeksprojekten van het VDI-Technologiezentrum en het Wissenschaftszentrum Berlin (WZB). Sinds 1 januari 1988 is hij als programmaleider verbonden aan het Maastricht Economic Research Institute on Innovation and Technology (MERIT), waar hij verantwoordelijk is voor het programma Technologie en Arbeid. 



$$
\Longrightarrow
$$

